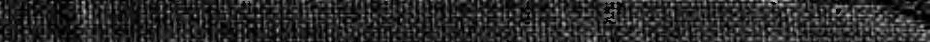

Fit

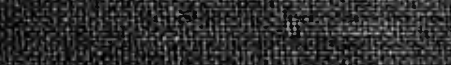
48.

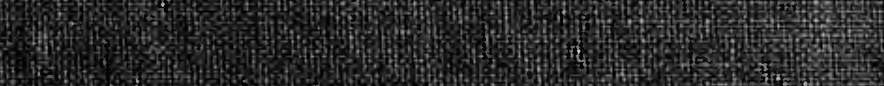

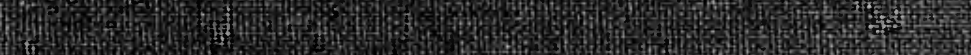
5.2. that

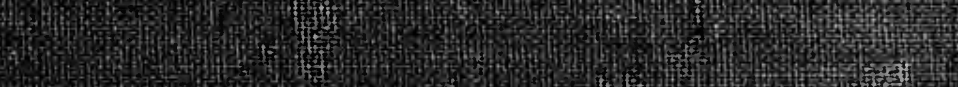
s.

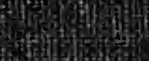
U: 18.

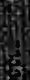

$$
\text { (1) }
$$

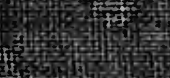

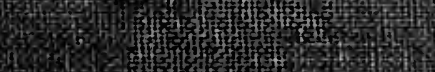
3.

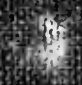




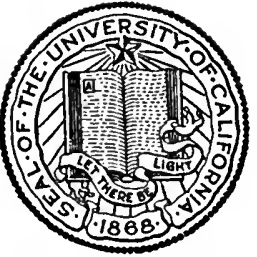

THE LIBRARY

OF

THE UNIVERSITY

OF CALIFORNIA

RIVERSIDE 


$$
\begin{aligned}
& \text { SUनERGM } \\
& \text { SUNAGGE }
\end{aligned}
$$

Francist Htood 


\section{Digitized by the Internet Archive in 2007 with funding from Microsoft Corporation}


THE ORIGIN OF THE ENGLISH CONSTITUTION 
BY THE SAME AUTHOR

An Outline Sketch of English Constitutional History

(Second printing.) $5 \times 73 / 8$. Cloth. 208 pages. 


\title{
THE ORIGIN OF THE ENGLISH CONSTITUTION
}

\author{
BY \\ GEORGE BURTON ADAMS, LitT.D.
}

Enlarged Edition

NEW HAVEN - YALE UNIVERSITY PRESS LONDON - HUMPHREY MILFORD - OXFORD UNIVERSITY PRESS MDCCCCXX 
$J N 1=8$

A 33

i) $0^{2} 1$

COPYRIGH'T, 1912, BY

YALE UNIVERSITY PRESS

First printed, 1912

Second edition, enlarged, 1920 
TO THE

MEMBERS PAST AND PRESENT OF MY

SEMINARY IN ENGLISH INSTITUTIONS 



\section{PREFACE}

Some articles and portions of articles previously printed have been brought together in this book, and I am indebted to the editors of the American Historical Review and the English Historical Review for permission to republish them. To the chapters which most nearly follow these earlier articles, some additions have been made in the text, and especially in the notes. Two introductory chapters have been added, and the third and the fifth are also new, except for some brief passages in text and notes.

The purpose of the articles as originally published was to point out the feudal origin of the English Constitution in its most distinctive features, and especially of the limited monarchy, and to show that the function which the Great Charter actually performed in the formation of the Constitution was to effect the transition of the fundamental principle of feudalism into the fundamental principle of the modern Constitution. The object of the present book is the same. The introductory chapters are concerned with the institutions of general government before any tendency towards change began to appear, and the third with the changes of the second half of the twelfth century, in order to make clear that the original government was feudal and that the only decisive changes which occur before the date of Magna Carta are not in the direction of a limited but of a 
more powerful monarchy. The purpose of the fifth chapter is to make more evident the distinctive character of the Great Charter in itself.

The tendency in the past quarter of a century in the study of English constitutional history has been a growing recognition of the feudal character of the Anglo-Norman period. This may be clearly seen by comparing the discussion of institutions in Pollock and Maitland's History of English Law with the opinions prevailing a generation earlier, even with those expressed in Stubbs's Constitutional History. Bishop Stubbs represents, I am tempted to say, the beginning of the scientific study of the Constitution. This would, however, be unfair to a number of scholars whose work upon particular points is of the greatest value to the later student. But in the study of the Constitution as a whole, Bishop Stubbs's work does form an epoch from which all later work must date, and in nothing does it mark a greater advance than in beginning an emancipation from the idea of the unbroken continuity of Saxon institutions, so strongly urged by Professor E. A. Freeman, and in bringing the royal government of England into more close relation with contemporary continental institutions. Much has been done in the same way since his time. There remained, however, at the close of the nineteenth century three important points still to be emphasized. First, the need of a more unreserved recognition of the completely feudal character of the 


\section{PREFACE}

general government down to the end of John's reign, still unmodified by the new developments of the king's prerogative. Second, the exact point and manner of the divergence of the modern English Constitution from the feudal. Third, the specific service rendered by the Great Charter in that divergence and the method in which the service was rendered. As less important may be added, the necessity of emphasizing more than is commonly done the different effects wrought by the Norman Conquest in the spheres of national and of local government.

It is hardly necessary to point out to Americans that the history of the origin of the English Constitution is our history as much as it is the history of living Englishmen. Our institutional past until near the close of the seventeenth century is to be found in England alone. This fact the history of the seventeenth century shows clearly enough, for if one will study the constitutional innovations attempted or advocated during the period of Puritan rule, when the constitutional life of England abandoned for a moment all connexion with the monarchy, he will see how natural it seemed to the nation to turn to a surprising number of the political expedients which in our government seem departures from the English system. When Englishmen at home broke with their own institutional precedents, and began to make a republic, it was to things of this kind that their minds were naturally led, as if they had been trained to them.

$$
\text { [ix ] }
$$




\section{PREFACE}

As to the relation between cabinet and legislature, which appears to us now a very striking difference, we need to remember that our constitution was framed at a time when the workings of a responsible ministry were not understood in England itself, and could not have been described by any one as they were by Macaulay fifty years later. In an especial way, and this is true quite independently of our racial descent as individuals, the England of those early centuries wrought out for us more truly than for any other people not within the borders of her Empire, the institutions of free government, and we have a peculiar right to feel that in tracing the steps by which they were created we are studying our own history.

It would be easily possible in a book of this kind to multiply footnotes almost indefinitely. I have not felt them to be a necessary evidence of learning, and I have deliberately resisted the temptation to use them except where they seemed to me really to serve a need. I have also not reprinted passages from documents like Magna Carta which are easily accessible to all.

I wish to acknowledge, more explicitly than in my dedication, my obligation to the members of my historical seminary with whom many of the problems here discussed have been investigated, and from whose kindly criticism I have profited much.

New Haven,

March 5, 1912. 


\section{TABLE OF CON'TENTS}

CHAPTER I

General Introduction

Note A: The Limited Monarchy and the Constitution

41

Note B: Anglo-Saxon Feudalism - and Political and Economic Feudalism

CHAPTER II

Institutional Introduction

Note A : Private Jurisdiction and the Judicial Position of the Common Freeman

Note B: The Lord's Cases in His Own Court

Note C: On Glanvill, XII. 25

CHAPTER III

The First Age of Change

Note A: The Origin of the Court of Common Pleas

CHAPTER IV

The Germ of the Constitution

Note A: Ideal Feudalism in England

Note B: Feudal Legislation

Note C: The Feudal Contract

CHAPTER V

Magna Carta

Note A: The Documentary Series Which Magna Carta Opens

$$
\text { [xi ] }
$$


Note B: Feudal Aids

Note C: The Direction of Change in the Reissues of the Charter

Note D: Magna Carta, Clause 39

CHAPTER VI

'The Immediate Results of Magna Carta

Note A: The Argument for the Barons

CHAPTER VII

The End of the Period of Origin

314

Note A: The Writ of 1213

\section{CHAPTER VIII}

Magna Carta and the Responsible Ministry

342 APPENDIX I

The Descendants of the Curia Regis

APPENDIX II

Henry I.'s Writ Regarding the Local Courts

\section{APPENDIX III}

London and the Commune

Index

401

$$
\text { [ xii ] }
$$




\section{ABBREVIATIONS}
A. H. R.
American Historical Review.
E. H. R.
English Historical Review.
Gesta.
Gesta Regis Henrici Secundi. Rolls Series.
Madox.
Madox's Exchequer.
Penn. Transl. University of Pennsylvania Translations.
P. and M. Pollock and Maitland's History of English Law.
Round Cal. Round's Calendar of Documents Preserved in France.
Rymer. Rymer's Foedera, Record Edition. Vol. I.
Stubbs. Stubbs's Constitutional History.
Stubbs S. C. Stubbs's Select Charters. 

THE ORIGIN OF THE ENGLISH CONSTITUTION 



\section{CHAPTER I}

\section{General Introduction}

The importance of the English Constitution in the political history of mankind is so great that the question of its origin is of unusual interest. The unanimous judgment of the world at the beginning of the twentieth century is that this is the best system of government yet devised. All monarchies which have adopted a constitution have derived their forms from it, and the same is true of most republics. Local necessities, or local prejudices, have made the adoption in individual cases more or less complete, or have led to variations from the typical forms, but these are hardly sufficient, even in the most extreme case, to conceal the indebtedness. The English Constitution has made the circuit of the globe and become the common possession of civilized man. After so many centuries of experiment, practical action, whatever be the opinion of the theorist, unites to declare this the best result of all experience. If this is true, the question from what and how it began to be should be considered one of the greatest and most absorbing of all historical studies.

Some definition is, however, necessary for the sake of clearness. By the term constitution, as used above, 


\section{ORIGIN OF THE ENGLISH CONSTITUTION}

is not meant the whole system of government, all the organs of the state, the whole political machinery, national and local. What is meant is the machinery of a limited monarchy, those devices by which an absolutism, once existing in fact, can be retained in form and theory while the real government of the state is transformed into a democratic republic. ${ }^{1}$ It is this group of institutions, and those more or less closely connected with them, as adaptable to a democracy which has never known a king, as to the Empire of Russia, which we mean when we say that the English Constitution has become the common possession of mankind. And it is this limited line of institutional history only, national and not local, which I propose to consider in this book.

There is another qualification also which I wish to have clearly understood at the outset. I am trying to find the beginning of the English Constitution in the way of forms and machinery only. It is as a body of institutions that $I$ wish to trace its rise. From what legal and constitutional ideas, from what methods of doing the business of government, by what changes in those ideas and methods, was the process of creation carried on until we can say that the limited monarchy with its characteristic ideas and its characteristic machinery for doing the work of the state became fixed in the habits of the nation, this is the general problem which I propose. I know very well, however,

1 See note $A$ at the end of the chapter (p. 41). 


\section{that I am studying only a portion of the whole case.} Racial, social, and economic influences, and others very likely, had to do with the result, and no doubt furnished more of the impelling force of change, in many instances at least, than did anything that was institutional merely. These I shall have to leave to others, who will no doubt in their turn acknowledge that existing forms with which the more dynamic forces had to deal made exceedingly important contributions to the common result. ${ }^{2}$

2 The thesis of this book is that this English national constitution, as defined above, is a direct outgrowth of the earlier feudal constitution of the state; that it rests wholly upon foundations that were laid in the feudal age; that the distinctive features which made the English a constitution of a new type in the political history of the world came in the germ from feudal arrangements and were developed under the influence of principles derived from feudal law. The English limited monarchy of later times could never have been regarded as a direct outgrowth of the Saxon, non-feudal state, as it existed for instance under Cnut, cxcept by a preconceived and strained interpretation of the facts of history. The whole drift of that state was towards a monarchy of the Carolingian type in which the crude checks upon the sorereign's will or equally crude machinery for operating the nation's will, belonging to the primitive German public law, had either entirely disappeared or been dwarfed into insignificance. To speak of these, indeed, as checks upon the sovereign's will is to carry back our conceptions into the earlier time when they did not exist. They were not checks upon the sorereign's will as such in the Teutonic constitution. They were rather survivals of an earlier form of government disappearing before the new and rapidly increasing monarchical power. The Saxon monarchy adranced along this road so much more slowly than the Frankish not from any greater devotion of the race to liberty, nor because it possessed different or better institutions, but mainly because one set of influences, most decisive in hastening the results on the continent, was lacking-the Roman survivals, and because no Saxon state had suddenly imposed upon it the necessity of governing a wide territory with its primitive machinery. The accomplishment of such results was made impossible in England by 


\section{ORIGIN OF THE ENGLISH CONSTITUTION}

The Norman Conquest brought face to face with one another two groups of political institutions which in their historical origins had much in common, and which in some respects had passed through common phases of development. On one side was the Saxon. Its history had been begun in England by Teutonic tribes from the southeastern shores of the North Sea. Of their actual institutions before and for a time after the Conquest we know almost nothing, but they seem to have stood in a stage of political progress not materially in advance of the kingless tribes whose institutions are described in Tacitus's Germania. It is probable that the new conditions in which the Conquest placed them impelled them to changes in the direction of larger and stronger states. The king came into existence, charged it would seem likely, at first, mainly with the duties of a permanent war-chief in view of the dangers constantly threatening the little colony of invaders. From such a beginning his power spread gradually over internal policy and administration, and grew stronger. The increase of the royal power in the Saxon state seems to have been very slow, but it did increase. The Saxon monarch of the eleventh century was far from absolute, or the Norman Conquest. It was the thorough feudalization of England which resulted from the Conquest that made the constitution possible, not by establishing a strong monarchy against which primitive Teutonic liberty reacted later, but by introducing with the strong monarchy a new conception of the relation of the king to those of his subjects who in that age constituted the nation, and who alone could constitute it, by introducing the definite contract-idea of the feudal system. 


\section{GENERAL INTRODUCTION}

from being able to identify himself with the state, but in the hands of a king like Cnut it was a strong monarchy.

With the development of the kingship there had developed the institutional side of two other political functions which it is necessary for our purpose to notice- the administrative, and the combined judiciallegislative. From a beginning which was probably hardly more than a stewardship, to look after the private interests of the king in the divisions of the primitive state, the shire-reeve, the sheriff, had developed with the growth of the royal power into a general administrative and executive officer, having duties of great variety, judicial as well as administrative, executing the orders of the central government throughout the localities, and standing as well in close relationship with the local courts. It was a generic office, later undergoing much differentiation, but sufficing amply for the needs of a primitive government.

In the Anglo-Saxon state, as generally in an early stage of political development, the legislative function was scarcely exercised. Custom took the place of enacted law, and whatever institution had the duty of defining what the custom was and of deciding disputes about it, had as a natural consequence the power of making such slight changes in the law, or additions to it, as seemed necessary. In the Anglo-Saxon state the judicial-legislative function was exercised by an 


\section{ORIGIN OF THE ENGLISH CONSTITUTION}

assembly or rather by national and by local assemblies. The place and grade of these assemblies corresponded to the divisions and subdivisions of the territory of the state. The national assembly, widest in scope and apparently in powers, seems to have been an aristocratic body, formed by bringing together the chief men in church and state, with no very definite ideas that can be called constitutional of what its composition should be. In addition to its judicial and rather vague legislative functions, it seems to have acted often as a council, and in times of national crisis, as in the vacancy of the throne, or in a time of disputed succession, to have assumed some authority to express the will of the united tribal or national whole. Of the composition of the local assemblies of shire and hundred we have no clear information from Saxon times, but they seem certainly to have contained a more popular element, perhaps representative in character, and they exercised within their narrower spheres the same judicial and legislative functions as the national assembly. Most important from our point of view is the fact that, whatever the function exercised, the method by which it was exercised was democratic within the assembly. The presiding officer, whether king, or ealdorman, or sheriff, was a moderator only, having no official right of influence upon the decision of questions before the assembly, which reached its conclusions by the formation of a majority opinion. 


\section{GENERAL INTRODUCTION}

On the other side were the Normans. They were the descendants of the Northmen, or Scandinavian sea-rovers, who had settled on the north coast of Gaul, on both sides of the river Seine, at the beginning of the tenth century, three hundred years after the Saxon settlements in Britain had become firmly established and extensive. We know no more of their original institutions than we know of the Saxon, but they seem to have stood in about the same stage of political development and their monarchy also to have been developed after their settlement. If we may judge of the institutions with which they were familiar at the time, as we probably may, by what we learn of Scandinavian institutions in general from writings of a later date, they would not differ materially from the institutions of the Saxons and the conditions in which they were placed in the conquered land would probably tend to develop them in the same direction.

The Normans, however, underwent at once an experience to which nothing in Saxon history corresponded. They came into immediate contact with a governmental system and indeed theoretically formed a part of it, which was much more highly developed than their own-the Carolingian monarchy. This system, probably because they formed but a small minority of the population of the province they occupied, and because they found their more primitive institutions less fitted to cope with the practical difficulties of the situation, the Normans finally adopted 
in place of their own. The Scandinavian institutions which they brought with them seem in the end to have disappeared without leaving discernible traces of any importance. ${ }^{3}$ The institutions which the Normans brought into England, therefore, were those of the Frankish monarchy.

These again were Teutonic in their origin, probably not materially different from those of the Saxons, though the kingship had developed among the Franks before the conquests of Clovis began. But the contact with the Roman governmental system resulting from the occupation of Gaul had had the same effect upon them, though to a less degree, that the settlement in Normandy had upon the Scandinavian, much that was Frankish remained in use but much that was Roman was added to it, or mingled with it to form something that was not quite either.

We shall be concerned later with a number of details of this Frankish system, but in this general introductory survey we need to notice the larger features only. The Frankish monarchy at the beginning of the reign of Clovis had been apparently not more than the kingship of a small local subdivision of the Frankish tribe, many of which existed at the same time, not unlike the small kingdoms probably first resulting from the Saxon settlements in Britain, but the military needs and successes of Clovis's conquests had carried the Franks in a single generation 3 See H. Brunner, Geschichte der Englishen Rechtsquellen, p. 62 (1909). 


\section{GENERAL INTRODUCTION}

through a development which in England had taken many. It is probable also that the model of Roman centralization, which a conquest so rapid left largely undisturbed, exerted an influence in the same direction which the Saxons never felt. At the end of Clovis's life a powerful monarchy had been established, which was strengthened by his immediate successors, and then, after a period of decline, further strengthened and institutionally perfected by the early Carolingians.

The growth of this monarchical power had been accompanied by some change in the character of local institutions though less than might be expected. The Frankish local courts, originally closely analogous to the Saxon in function, procedure, and probably in composition, had survived, though they had become less democratic in operation, a board of appointive officers, the scabini, making the judgment of the court in place of the popular assembly. A local administrative officer, representing the king, and exercising throughout the local divisions of the state functions closely similar to those of the Saxon sheriff, though an office apparently quite different in origin, as it was in history, existed in the count or graf. The opportunity which an office, uniting in one hand so many of the functions of government for a definite locality and held usually for life, offered to its holder to become independent or to recognize only a vague dependence on the central power, had been often 
embraced under the weaker Merovingian kings, but the early Carolingian princes had reduced these officers to a new obedience and held them under a strict control as true administrative officers, but still of a generic type.

Of a general assembly of national scope and democratic in character, open to the ordinary Frankish freeman, scarcely a trace remained. There was, however, a king's council or court, composed of the officers of the king's immediate household and the chief men of the church and state. In the things that it was accustomed to do, as in composition, it was rery like the Saxon national assembly, and seemed to perform judicial, legislative, and conciliar acts without consciously distinguishing them in character. If local assemblies corresponding to the shire courts of Saxon England existed in the Frankish state, they certainly left few traces in the evidence which has come down to us, but of the hundred assembly there is no doubt.

At the beginning of the tenth century when the settlement of the Northmen was made along the lower Seine, the Frankish monarchy had recently passed into a second period of decline. A variety of causes, partly political and partly economic, had combined to render the exercise of a real central authority orer the great empire which the earlier Carolingians had created exceedingly difficult and to favour the rise of local powers, acknowledging in form the supremacy of the emperor but actually independent in the prac- 


\section{GENERAL INTRODUCTION}

tical government of their territory. The leader of the Normans, as count of the lands they occupied, was the representative of the emperor as the officer to whom it belonged to make the authority of the central government effective in that portion of the empire. In the actual powerlessness of the monarch, he fell heir to that authority as if it were his own, and he was able to prevent a further weakening of it in his hands. As his territory assumed by successive grants or occupations the size of a small kingdom, coming not badly off in this respect in a comparison with the kingdom over which Alfred the Great actually ruled, his power became really sovereign and found in extent and effectiveness hardly an equal in the tenth and eleventh centuries.

In regard to other institutions it seems highly probable that there had already come into existence in Normandy administrative and judicial-legislative institutions very similar in character to those of the Saxons. The local administrative and financial officer bore in Normandy the name of viscount-the vicecomes-the count's deputy, becoming as necessary to effective local government when the county assumed more and more the character of a kingdom, as the count had originally been for the king of the Franks. The tendency of these deputies to become independent, which showed itself throughout the whole Frankish state, the strong Norman counts had been able to hold in check and they seem to have main- 


\section{ORIGIN OF THE ENGLISH CONSTITUTION}

tained as firm a hold over their viscounts, in nearly every case, as Charlemagne had maintained over his counts.

For Normandy as a whole there seems also to have been an assembly similar in composition and function to those of the Frankish empire and the Saxon kingdom. The chief men, lay and ecclesiastical, of the province, less conscious now, it is probable, of performing a public than a feudal duty, met in an assembly for the whole territory subject to the count and did such judicial, legislative, and other business as needed attention. ${ }^{4}$

The evidence which has come down to us from which we can describe in detail the institutions of Normandy, before the Conquest, is even more scanty and fragmentary than that for Saxon institutions, but the larger features which have been here sketched seem nearly as well established for the continent as for the island. It is possible for us now to say that not merely in remote origins and in some phases of development, but also in general features, the two groups of institutions brought face to face by the Conquest were strikingly similar. In details, and in details that were important in the subsequent history, there were many differences, but at the moment of the Conquest they would count for less than the larger similarities and these embrace the whole structure, and operation 4 Lucien Valin, Le Duc de Normandie et sa Cour (1910). 


\section{GENERAL INTRODUCTION}

of such machinery as existed for the government of the state as a whole.

It is evident a priori that a conquest which should make the Norman the ruler of the Saxon and able to determine the institutional character of the resulting state, need lead to no violent constitutional changes, but that it might rather bring about a new government by an almost easy and natural combination of the two sets of institutions which it threw together. In other words it was possible that a new government might be formed in England by an amalgamation of Norman and Saxon institutions without giving to anyone the impression, certainly not so strongly as to get into the record, that revolutionary or violent changes had been made. We may almost say, indeed, that if the whole of Saxon institutions had been swept away, if that were possible, and Norman had alone survived, the change would seem more revolutionary to us, thus baldly stated, than it would have seemed in the actual experience of contemporaries. The two sets of institutions were so nearly alike in all their essential features that conquest of one by the other was hardly possible, but a union between them was easy and almost inevitable. ${ }^{5}$

5 The process, however, even to its final end can hardly be called one of union. For a time Saxon and Norman stand side by side, for a long time in some things, as in local government, the one scarcely influenced by the other in any way that can be clearly proved. Gradually the Saxon disappears, or if it does not disappear, it has been absorbed into what is essentially Norman or derived from the Norman, by a process which can hardly be called the union of two into one, but is rather the 
Such a result was made practically certain by the disposition of William the Conqueror. He was "the conqueror" beyond all question, but he makes it clear to us by many acts that he did not wish to be regarded in that way by those whom he had conquered. $\mathrm{He}$ would tolerate no rebellion, from Norman no more than from Saxon, but his authority being recognized, he desired to rule as an English king would have ruled in his place, and the most decisive changes which he introduced, except in ecclesiastical matters, he probably did not know to be changes. It is not likely that he ever understood how extensive the innovations really were which he actually made. His first official act, so far as we know, after his coronation was his charter to the city of London and it is typical of his attitude throughout his reign. It is hardly a city charter in the later sense, granting economic and political privileges and defining local government. Its brief and general statements are in line with much that was contained in the later charters, in that of his son Henry I. for the same city, for instance, but the differences are equally striking. Certainly to those to whom it was addressed in the circumstances of the moment, it would seem rather to be a proclamation, modification or variation of one by the other. But the main result is clearly Norman, that is, the result of Norman development on English soil. A fine example of the way in which the two systems of law stood over against one another just after the Conquest is to be found in William's writ on procedure, Liebermann, Gesetze, I. 483 . It is also a fine example of the great consideration shown to Englishmen in the operation of the law. 


\section{GENERAL INTRODUCTION}

the proclamation of a conqueror defining his policy, and it would say to them chiefly that no foreign law was to be introduced, that no confiscation was to be made, and that his army was to be restrained from violence. It was a proclamation, however, put into the form of a charter, that is, of a legally binding grant. The promises of this proclamation were faithfully kept, so far as we know, to the city of London. They were not kept to the country at large, but William's plea in defence would have been one of necessity, and I think we must admit its sufficiency, judged by the standards of the eleventh century. A large body of foreign law was introduced and became firmly rooted in England, but no foreign law was introduced of deliberate intention. Extensive confiscations were made, affecting perhaps all, at any rate a considerable part, of the land of the kingdom, and a new theory of final ownership was introduced. For these things we can only admit such justification as may be found in the necessity of thoroughly garrisoning the country, though we may say, if that be extenuation, that the aristocracy suffered most from them, not the great mass of the population. ${ }^{6}$ The

${ }^{6}$ See The Political History of England, II. 12, 13. One is sometimes tempted to wonder if the way in which his guarded statements are treated is fairly to be taken as evidence of how his critic handles the original materials upon which he bases his own scientific conclusions. See Ballard, Domesday Inquest, p. 5, which reads: "Dr. Adams says that it is an error to believe that the Conqueror considered all the land in England to be forfeited to him, and thinks that these payments 'to redeem their lands' were nothing more than the customary feudal relief which was paid by 


\section{ORIGIN OF THE ENGLISH CONSTITUTION}

violence of the army was not always restrained, nor his own violence, to his lasting shame, but we must acknowledge that as he would regard the situation his patience was severely tried, and he had much provocation.

Using the word constitution in the sense to which it was restricted at the beginning of this chapter, the organization of the national government as distinguished from the local, it is my own belief that the history of the English Constitution upon English soil begins with the Norman Conquest, and that, whatever may have been the character of the Saxon national organization, it made as such but little contribution to the later result. The institutions of general government which grew in England and in course of time passed into the institutions of the modern state are in all the most important particulars those which were brought in by the Normans in $1066 .^{7}$

a tenant to his new lord." In the passage referred to at the beginning of this note it will be found that the suggestions which are made are plainly put forward as mere conjectures.

7 The use of such words as government and state in a connection like the present is open to objection. They convey to the modern mind the idea of a political organization more highly developed than really was the case. There is, however, no good substitute for them, and to refuse to use them in cases where there really was a political organization and a government in many matters effective, extending orer the whole community, and serving the same purpose for the needs of that age which the government of the modern state serves, savours of pedantry. No careful student is likely to be led astray by such terms. The word nation is open to more serious objection since anything corresponding to the modern idea, even in rudimentary form, can hardly be said to have existed in the twelfth and early thirteenth centuries. 
While there may have been so great a similarity of Saxon and Norman institutions that no evidence of violent substitution of one for the other is to be found, there can be no doubt but that it was the Norman constitution, with whatever peculiarities it possessed, which ruled henceforth. And beneath the superficial similarity, there was great difference. The Norman was a centralized absolutism, organized and operating by means of the feudal system. If anyone inclines to think this too definite a statement for what we know of the Norman government before 1066, it certainly is the government which ruled in England after Christmas day of that year, and there is no evidence of any constitutional transformation which followed the battle of Hastings. Cnut's was a powerful monarchy and England was held in his time with a strong hand; Edward the Confessor was a strong king, potentially if not actually; but the absolutism of William I. is a monarchy of a different type, both in spirit and in practical operation. As to the legislative machinery, so much alike on the surface were the two institutions that the Saxon Chronicle went on for a long time calling the Norman curia regis by the old name of witenagemot as if the writers thought there had been no change, but the institutional difference between the two is very wide. There are many things in Saxon society which have a strongly feudal appearance, and in its later history we detect easily some of the most important elements which went to 
form completed feudalism, but the Saxon government was certainly not getting its business done and the Saxon landholder was not performing his public duties, as incidents in a prevailing feudal organization. $^{8}$ Towards all these things I have no doubt the Saxon world was rapidly drifting, but the Norman Conquest interrupted the process. We may characterize the change it wrought accurately, I think, by saying that what the Norman Conquest did was to carry the English Constitution forward suddenly, overnight as it were, to results which it would itself have been likely to reach after some generations, or at least to very similar results.

But this is only the same as saying that, if we wish to know the earlier history of the royal power which William the Conqueror exercised, we must seek it in the Frankish and not in the Saxon state. The Saxon development towards a strong kingship, however great it may have been, comes to an end with 1066 . It can be regarded as preparation only. It is the Frankish which goes on from that date. And it is so, in differing degrees, with other things. Saxon witenagemot, the national assembly of the chief men of church and state, becomes the Norman curia regis composed of the king's vassals. Function does not change, but function is never a test of institutional difference, and the principle of composition is decidedly different. The Saxon earl disappears, the 8 See note $B$ at the end of the chapter (p. 44). 


\section{GENERAL INTRODUCTION}

Norman count of that day takes his place, though the English name continues. In superficial appearance the office of sheriff seems to have changed very little, but this primitive organ of centralization shared in the increased royal power and obtained a local authority and a range of activity which it would probably have been some time in reaching by natural growth. These may serve as examples of the general fact. The change is either so great that we have a right to say that it is the Norman and not the Saxon which goes on, as in the case of the monarchy and of the witenagemot, or it is great enough to contribute the essential element of future growth as in the case of the shrievalty.

It should be clearly observed that I am saying nothing here regarding the great province of local institutions and local law. That is the field in my opinion of which Saxon institutions kept possession and in which comparatively few Norman innovations were made, except so far as feudalism and later the new judicial institutions entered the field. But with local institutions I am to be in this book only incidentally concerned. ${ }^{9}$ In the case of institutions through which the business of the country as a whole

9 A distinction between the local and the national, based upon differences of origin, history, or character, is possible in the history of other countries besides England. In present France, for example, the national government has been profoundly changed since 1799 and has few roots in French history of an earlier date, but this is far less true of the local government. 


\section{ORIGIN OF THE ENGLISH CONSTITUTION}

was managed, while superficial appearances in many cases seem unchanged, any minute examination will show that in necessary institutional interpretation, as of the witenagemot, the change is great, or that the impulse to fruitful growth is new.

Of these Norman innovations in the field of general government two greatly exceed all others in their influence on the future. They are the centralized monarchy and the feudal system.

Of the centralized monarchy it is not possible to say much beyond a statement of the fact itself. It is my own belief that the executive and administrative power of the Norman duke and his practically unlimited control of his little state came to him in direct descent from the strongest age of the Carolingian monarchy combined with the fact that he was at the beginning the chief of a conquering invasion which settled upon the land. The real descendants in early Capetian times of the strong rulers of the Carolingian empire at its height are to be found not so much in the occupants of the throne as among the successors of those local agents through whom the imperial centralization had been exercised-counts and viscounts now become feudal barons, or of those who by usurpation had assumed their rights and names. They are found among the greater where the count or duke had succeeded in checking the tendency to further division of these powers, as in Normandy, possibly because of the fact of conquest, and among the barons 


\section{GENERAL INTRODUCTION}

of some subordinate rank in cases where that tendency had not been checked, as in Aquitaine. The powers once exercised as the instruments of a strong monarchy they continued to exercise as if they were their own. I am not saying that the Capetian kings ever surrendered their claim to the complete government of the state in all particulars; that they never did, and probably we should now recognize a larger actual power in their hands than would have been admitted fifty years ago. But throughout the larger part of modern France in 1066 the actual government which came into immediate contact with land and people and maintained law and order locally was not exercised by the king but by some feudal baron holding under his control a larger or smaller district. In Normandy the district was large and the control was strict, except possibly over some subordinate lordships lying on the borders. ${ }^{10}$

With reference to William's government of England the fact should not be overlooked that the Normandy over which he ruled before the Conquest was in area a very respectably sized kingdom for the eleventh century. Few sovereigns of his day con-

10 Any assertion concerning the absolutism of the Norman duke before the Conquest which deals with details, if regarded as dogmatically made, is likely to go beyond our present possibilities of proof. What I have said should, therefore, be considered as my personal belief only. The fact should not, however, be overlooked that as we learn by degrees more and more of the conditions of pre-Conquest Normandy, their likeness to those in England immediately after the Conquest becomes more apparent. 


\section{ORIGIN OF THE ENGLISH CONSTITUTION}

trolled with anything like the same actual effectiveness a larger territory than his. So far as concerns the difficulty of that age which created the most serious problem for a general government, the difficulty of intercommunication, England as conquered by William was not enough larger geographically to render the methods and machinery of his Norman government less effective there than at home. England, indeed, presented no difficulty of general government which William's experience had not trained him to overcome. For William, certainly the simplest and most natural thing would be to transfer to England bodily the entire machinery of government as he was operating it in Normandy, and that is undoubtedly what he did. For England, the experience of almost a hundred years, since the beginning of the second Danish attack, in the drift of the monarchy towards absolutism and of local arrangements towards things more nearly feudal, had been preparing to make the transition easy, easy for William to make the transfer, and easy for Englishmen to reconcile themselves to the new with little sense of violent change.

Whatever may be true of Normandy, in England the result of the campaign of 1066 was the establishment of a monarchy so absolute that there was neither in the law nor in the practices of the time any recognized method of setting a limit to its action, or perhaps it would be more accurate to say that the sovereign 


\section{GENERAL INTRODUCTION}

was limited only by his own sense of obligation to existing law, which was almost wholly customary and unwritten, and that the only means of enforcing such law upon him was by individual protest, or by more or less general rebellion." This absolutism was exercised in practice through an organization simple and

11 The Norman king cannot be said to be absolute in the extreme, or ideal sense of the term. He is suzerain as well as king, or better, he is suzerain because he is king, and as such he is limited by the obligations assumed in the feudal contract, and by the property rights of the barons, created and protected by that contract. The point which I wish to make in the text is that there was no recognized and permanent machinery, which may be called constitutional, for enforcing this or any other limitation. As a matter of practical operation, this feudal limitation seems to have been effective only where the law was clearly against the king, and the party of barons in opposition large and strong enough to determine the opinion of the curia regis and to out-balance the force which the king could collect. See the cases referred to in note 22 to chapter IV. Such cases are virtual appeals to force, and they succeed without open force because the opposition is too strong to be overcome. The case of William II. against Anselm at Rockingham in 1095 is typical enough. The king seems to have hoped to put the archbishop in the wrong legally, as acting in violation of the fealty owed him, in order that he might get rid of him entirely as archbishop. This seems to be the real meaning of the demands made of the bishops and barons (Eadmer, 62-64). If this could be done, it would be treating the spiritual office as dependent upon the political conduct of the incumbent, to be declared vacant as the office of sheriff might be on the disloyalty of the baron holding it. In other words, it would be regarding the archbishopric solely as an office of the state. Such a plan would be a natural and entirely logical result of lay investiture as practiced by the Norman kings, and William may very well have believed that he was acting entirely within his legal rights. The barons, however, did not share his belief as they evidently did not his view of the relation of church and state, and the king failed to accomplish his design. How much this experience may have had to do with Anselm's later position on the subject of lay inrestiture it is not possible to say, but it is easy to imagine that it may have opened his eyes to the consequences of the practice. 


\section{ORIGIN OF THE ENGLISH CONSTITUTION}

even crude in character, but one which created a true and effective centralization unsurpassed in any other country of the time. The institutional details of this organization will be described in the second part of this introduction; here I am concerned with the practical result. What that was cannot be mistaken. It is perhaps best seen in William's own confidence in the security and strength of his position. He was not afraid within three months of his coronation, with but a fraction of the country actually occupied, to return to Normandy for half a year, leaving his conquest in the hands of subordinates. He was not afraid, in the distribution of confiscated lands to his followers, to create solid, or almost solid, principalities, as for one brother in Cornwall where nearly the whole county, and large territories in adjoining counties, were made into an earldom, and for another brother one less extensive but in some respects even more dangerous, on the east side of England. He was not even afraid in the case of three at least of these great lordships, Shropshire, Chester, and Durham, to vest in their holders almost the rights and functions of the king himself. Events justified his confidence. When two of the most powerful of the Norman earls, hoping apparently to gain greater independence, and possibly excited by the fact that the king's fiscal agents, the sheriffs, had infringed some of the privileges granted them in their lands, appealed to arms against the king, the failure of their attempt was immediate 


\section{GENERAL INTRODUCTION}

and complete. ${ }^{12}$ When later in his reign his brother, Odo, showed himself determined to follow a policy of his own in disregard of William's wishes, he was arrested, tried, and condemned, with no possibility of resistance, and released from imprisonment only by the king, upon his deathbed, reluctantly yielding to persuasion. Not only was there in the reign of William the Conqueror no recognized method of marking out any limit to the king's exercise of power, but we may almost say that no attempt was made, certainly no concerted attempt was made to check its exercise or to define its limits in practice.

It is true, however, that William I.'s character served as a check upon arbitrary government. Once or twice he lost control of himself and acted for the moment upon the impulse of passion, but almost always though severe he was just, and respected law as it existed, and the customary rights of churchman and layman. It is under his son William II. that we get our first evidence of what the Norman monarchy might be in the hands of a tyrant. We may believe that the evidence regarding his reign which has come down to us, almost exclusively from ecclesiastical writers, should be received with some qualifications, that in personal character at least William Rufus was not quite so bad as he was painted, ${ }^{13}$ and yet when all 12 The Political History of England, II, 61.

13 It is natural in a society which reasons little about its political situation, but is strongly influenced by religious feelings, that condemnation of the methods of government should be translated into condemnation 


\section{ORIGIN OF THE ENGLISH CONSTITUTION}

reasonable deduction has been made, it is clear from these and other sources that in respect for what was regarded at the time as the rights of his subjects the reign is in contrast with his father's; that he was governed by his will alone, and that he pushed the rights of the king to extremes which were logical perhaps, but which the customary law of the time did not recognize. In such a reign, if ever, checks in institutions or in practice would make themselves evident. But we find no indication of anything that may be called a constitutional limitation. Rebellion was the only thing to which appeal could be made and rebellion was as powerless against him as against his father. There is no evidence that William II. ever refrained from any action which he earnestly wished to perform either because it exceeded his legal powers or because he was afraid of the opposition he might excite. $^{14}$ It seems natural to suppose that we have a less complete picture of his tyranny, unbridled to the end of his reign, than we have of John's, merely because our sources of information are less complete.

It is at the beginning of the reign of Henry I. that of the personal character of the ruler. There were many instances of this in medieval times, from Charles Martel on, and we may suspect that John has also suffered from this tendency though to a less degree than William II. Geoffrey Gaimar's brief account in his Estoire des Engles is the only lay narrative of William's reign which we have, and he says

Unc ne fust rei si bien amez,

Ne de sa gent si honurez. 11. 5923-4.

1t See note 11, p. 23. 


\section{GENERAL IN'TRODUCTION}

we detect the first effort to transform the moral limitation of the customary law, which hitherto would have such force merely as the conscience of the king allowed it, over into such a definite, legally binding, and permanent form that we may begin to call it constitutional. The coronation charter of Henry added nothing, or it would be more accurate to say that in theory it added nothing, to the law as it existed. What it attempted to do was to introduce the new theory and to make it a part of the law, that the throne was held, at least in Henry's case, on condition of faithfully observing the obligations of the customary feudal law. This principle, indeed, or rather the foundation upon which it logically rested in law, was not new, being essential to the feudal relationship, but to form out of it an explicit and written contract for the bestowing and the holding of the throne, which was the virtual character of the coronation charter, was new. The attempt, however, was a failure, and, except as a model for later imitation, it had no effect on the growth of the constitution. After Henry had put down the great insurrection which threatened his power at the beginning and had overcome his brother Robert, he proved himself like his father and his brother William so strong that no limitations could be enforced upon him. This is clearly shown by the fact that the feudal innovations, if they were innovations, so far at least as we can judge of them from the practices which the barons in the charter insisted 


\section{ORIGIN OF THE ENGLISH CONSTITUTION}

should be abandoned, were not merely continued in use but passed after his long reign into the undisputed feudal law of England. ${ }^{15}$

It is not necessary to carry this sketch further. The reign of Stephen was the reign of a king who did not exercise the power of his predecessors, but the difference was occasioned not by any change in the institutional situation but by the character of the king. Lack of will power and of the comprehensive grasp of things necessary to maintain order in a state of the twelfth century, where intercommunication was so uncertain, were the reasons for Stephen's failure. What characterized his time was not a limited monarchy; it was anarchy. The royal power as it had existed under the first Henry was speedily reconstructed by the second. But with the reign of Henry II. we reach a new epoch, the first epoch of change in the machinery of the Anglo-Norman state, but, as we shall see later, the changes of that age were all in the direction of a more effective, a better operated centralization, and of a stronger monarchy. No trace can be found in Henry's reign, or in Richard's, or John's, until we reach Magna Carta, of any attempt to create limitations upon the action of the royal will, or to devise machinery for the expression of a will opposed to the sovereign's. The Anglo-Norman

15 For instances of the treatment of vacant ecclesiastical fiefs under Henry I., see Red Book of the Exchequer, pp. $210,211$. 


\section{GENERAL INTRODUCTION}

monarchy was institutionally an absolutism, and in practice probably none was ever more so.

It must not be supposed that I am asserting that it was in this respect exceptional among the monarchies of the time. In institutional methods the Anglo-Norman monarchy at its climax of development, let us say during the absence of Richard in the Holy Land, considered as a government of the whole country, scarcely differed by the addition of a detail from the Carolingian monarchy at its highest point. There were some differences of form, there had been considerable perfection of details, the centralization was better guarded, and the growth of feudalism had transformed the institutional basis of some important matters, but while most of these changes did indeed tend to a stronger and more secure monarchy, still in really essential character, looked at as machinery and looked at from the side of the king, the government of Richard was in effect the government which Charlemagne left to his son Louis the Pious, strengthened and improved. ${ }^{15}$ Now this government was inherited by all the fragments into which the Carolingian empire broke. Some details which the Norman state retained, or it may be we should say revived, disappeared elsewhere, but the reason for that is to be found in what is in truth the reason for the differ-

16 That is to say, the effect of the development of the king's prerogative action during the twelfth century had been to secure and strengthen the royal centralization. See chapter II., note 21 . 


\section{ORIGIN OF THE ENGLISH CONSTITUTION}

ence throughout between the Norman monarchy and its contemporaries -in the character of the sovereigns, aided perhaps by the fact of its comparatively small geographical extent. The Norman monarchy was more absolute than any other not because of any institutional difference but from a practical reason, the machinery which it had inherited it kept in effective and successful operation, for its original purpose and in its original spirit, or at least it did not allow it to pass out of use for so long a time as to be beyond the possibility of revival. This Carolingian absolutism the Norman Conquest brought into England, and the results of the Conquest maintained it, and greatly perfected it, during a century and a half. The first great fact with which the history of the English Constitution begins is the absolute monarchy institutionally unlimited.

The second fact, equally fundamental, is feudalism. ${ }^{17}$ Of it in relation to the past the same is to be

17 It may seem as if the existence together in one state of a centralized monarchy and a feudal system would be impossible, and I think this has been unconsciously assumed by students of early constitutional history. But certainly the most fundamental fact in English constitutional history, that from which all else proceeds, is the existence together during a long period of time, of the most highly centralized monarchy and the most logically developed feudalism of contemporary Europe. If one turns aside from the localizing and separatist tendency of feudalism, which is likely to be the thing about it which attracts most attention, and regards only its institutional side, it can easily be seen that there is nothing in the nature of the case which prevents an absolute monarchy and a logical feudalism from existing side by side. Feudalism viewed from this point is only a particular method of organizing the machinery of carrying on government. 
said as of the monarchy. Such development of things feudal as had taken place in Saxon times served only as preparation for the easy introduction of the more perfect and highly developed Norman feudalism, and Norman feudalism it is which takes possession of England and influences her institutional future. This influence it exerts in two ways, first, directly, through institutions and law, second, less directly, through feudal ideas and the interpretations of other facts to which they lead.

Of Norman feudalism before the Conquest we can say little more than of the monarchy. Evidence as to its character is increasing, and if we can trust to present indications, we may say that it exhibits all the characteristic traits of the later Anglo-Norman feudalism. ${ }^{18}$ Norman feudalism on the eve of the Conquest had apparently realized in practice all the fundamental ideas of Franco-Roman feudalism, and had done so in highly logical form, and this feudalism, tending to approach an ideal standard, existed in the presence of a supreme central authority whose task it did render more difficult but which it did not seriously weaken; it rather served as the means through which government was carried on. So far

${ }^{18}$ On feudal institutions in Normandy before the Conquest and during the reign of William the Conqueror, and on the government of the duchy in general, see the studies of Professor Charles H. Haskins as published recently in the English Historical Review and the American Historical Review, especially volumes XXII. to XXVI. of the former, and VIII. and XIY. of the latter. 
as we can tell from the glimpses which we get of this pre-Conquest Norman government, we seem to have the right to say that the legislative, judicial, conciliar, and military functions of the state in their ordinary operation were thoroughly feudalized, and the administrative system partially so, but that in the latter regularly we find the province of the most independent action of the executive authority, especially in matters financial, though such action is to be seen occasionally in other functions of government. At any rate this is the character of the Anglo-Norman feudalism immediately after the Conquest and, though the consideration is no doubt a priori, it is difficult to suppose that any such transformation attended the Conquest as would be necessary to put so completely feudalized a governmental system in place of one less thoroughly so. We should naturally expect the influence of the Conquest to be in the opposite direction, if in either, and certainly in the evidence accessible to us there is no trace of such a substitution.

I am not asserting that the Conquest brought Anglo-Norman feudalism into England in its final form, that there was no difference between the feudalism of William I.'s reign and that of a century later. The year 1066 falls still within the formative age of feudal history, and England not merely shares with the rest of the feudal world certain changes which take place elsewhere, chiefly in the interest of the vassal, but also herself carries through certain other 
changes, logical enough but peculiar to herself, or nearly so, in the interest of the suzerain.

But if the year 1066 falls still within the formative age of feudal history, it is near the close of that age. It was a highly perfected, highly logical, widely embracing feudalism, which the Conquest introduced into England. It is just as difficult to suppose that the mere fact of the Conquest transformed the incipient, chaotic, Anglo-Saxon feudalism into the feudalism of Domesday Book ${ }^{19}$ and contemporary documents, as to suppose that it created Anglo-Norman feudalism at a blow. The process which seems a priori the most natural to expect and the most easy certainly has the support of such evidence as we possess. This

${ }^{19}$ Domesday Book was, of course, drawn up to record chiefly the economic side of feudalism. Anything else which appears in it is incidental and largely accidental. But information concerning political feudalism is not, therefore, insignificant in amount when it is put together. The structure of the book itself is feudal. It assumes that the prevailing organization of the land, and of the society with which it concerns itself, is chiefly feudal. The vassal relationship dominates every other and is greatly in advance, institutionally and in the definiteness with which it is understood and operated, of the Anglo-Saxon commendation relationship. It includes, for instance, in one bond both land and person. Military feudalism is everywhere, the domain manor on every page, the private court is clearly recognized, and many details of feudal law, homage, reliefs, wardship and marriage, trial by peers, etc., may be collected from brief and indirect references in its pages. One must also remember in the study of Domesday Book that the evidence in it of royal extra-feudal action, as in the commissioners and the juries, or of the operation of local non-feudal machinery, as in the county courts, and the hundreds, is no evidence of the incompleteness of feudalization. It is the operation of these three things togetherthe feudal machinery of general government, the non-feudal prerogative action of the king, and the non-feudal machinery of local governmentwhich constitutes in full the Norman state. 


\section{ORIGIN OF THE ENGLISH CONSTITUTION}

is that William the Conqueror, having the way prepared by the prevalence throughout England of ideas and practices which were feudal, so far as they went, introduced bodily, with no serious disturbance of things, the more perfected political feudalism of Normandy and set it up as completely in possession of government and society as it was across the Channel. This was indeed the only course possible to him. To have freed himself and his kingdom from feudal ways of doing things and to have invented instead a nonfeudal organization for the business of government would have been as impossible as to have taken advantage of the Conquest to set up what we know as the Anglo-Norman feudal system from a less developed original without marking our sources of information with indelible evidence of the process. William had been brought up from his earliest youth in feudalism and he had never known any other method of organization. When he parceled out the lands of England among his followers he could not do otherwise than to give them to be held by a feudal tenure and by feudal services, and by this very fact he unavoidably introduced the whole feudal governmental system since that operated itself entirely by means of feudal tenures and feudal services.

The ways in which Anglo-Norman feudalism served as machinery for the central government in the performance of its functions will appear in important details later in this book; here we are concerned 


\section{GENERAL INTRODUCTION}

with the more general fact of its introduction and with the outline of its history to the first age of constitutional change-the age of Henry II.

It is a traditional interpretation of the reign of William II., and the interpretation seems to find not a little support in the evidence, that his tyranny consisted in pushing to extremes the rights of the paramount suzerain, which were logically involved in the feudal relationship, particularly in such matters as relief and wardship, and in insisting on applying these rights, as his father had not done, to baronies held by ecclesiastics. The evidence to support this interpretation of his action in regard to fiefs of the church is not extensive but is fairly conclusive. For the rest some vague complaints, like that of the Saxon chronicle that he would be every man's heir, and the coronation charter of Henry I., are the chief evidence. The evidence is enough to warrant us in the absence of more definite knowledge in assuming that the traditional understanding is correct. If it is, the reign of William Rufus is a period of advance in two directions, first a more logical and complete development of fundamental feudal principles, giving us a more nearly ideal feudalism, ${ }^{20}$ but second a development in the interest of the suzerain, in this case more immediately of the lord paramount. In this way the already strong Norman monarchy would be further strengthened particularly in the clearer recognition 20 See note $A$ at the end of chapter IV. 


\section{ORIGIN OF THE ENGLISH CONSTITUTION}

of its complete hold over all feudal property and in its financial rights. There is, $\mathbf{I}$ think, no doubt but that we must say that this clear recognition of the king's rights, which is the distinctive mark of AngloNorman feudalism, is given it during the reigns of the Conqueror's two sons rather than in his own, though the principle from which it was developed was clearly recognized from the beginning-that all the land of the kingdom is held of the king.

The attempt made by the barons in the coronation charter of Henry I. to put an end to this development, an attempt certainly in the interests of the feudal baron, but not in the interests of a logical feudalism or of feudalism regarded as a means of general government, was a failure. ${ }^{21}$ The charter is

21 I do not mean to say that the barons understood their action in this way, or were consciously attempting to set up such restrictions at so early a date. They probably thought of nothing beyond the fact that the king's action had been illegal, and that they had a right to demand that it should stop. In strict feudal law they were right, I think, and they did not go beyond this right except in the matters of wardship and marriage. The customary is the legal in feudal law, and the new is illegal, no matter how logical, unless consent is obtained. What occurred, however, under William II. and Henry I., with the reservation in regard to our ignorance which $I$ have made in the text, seems to me to differ from what occurred in the Angevin period of centralization in this important matter, that the earlier innovations were logical deductions from feudal principles, while in the Angevin period feudal principles are calmly disregarded whenever they are found inconvenient. The clauses of the coronation charter which indicate most clearly its relation to the feudal law of its time are 3 and 4, relating to wardship and marriage. These provisions are so wholly out of accord both with what we know of later English practice and with the fundamental principles of feudalism if logically applied, and they are at the same time so clear in themselves and so significant of contemporary facts that they furnish the 
an evidence of the weakness of the king at the beginning of his reign. It was a bid for support, virtually extorted, and it would certainly be maintained in force, or such parts of it as hampered free royal action, only so long as the king remained weak. ${ }^{22}$ The period during which Anglo-Norman feudalism, considered from our present point of view as a part of the constitutional system of the state, was at its

most useful starting point for a study of the charter as a feudal document.

22 We may, perhaps, go so far as to say of the charter of Henry I. that the extreme severity with which the kings enforced their feudal rights and pushed them to the utmost limits, as in the case of wardship and marriage, had forced the baronage, with no very clear consciousness of the abstract relations of their action, to begin to study the question of the king's rights from their own point of view, and to endeavor to define and limit them by specific formulation. The charter of Henry I. as a statement of feudal public law is crude and incomplete. It could not be otherwise considering its date, and it is but slightly more so than the similar statements of both public and private feudal law which were made at about the same time in Italy; but its purely practical character is evident at a glance. It is an attempt by definition of existing rights to check a development of them in favour of the king which the barons had reason to fear had already begun. That progress in this direction was made during the following century is evident both in the far greater clearness of conception and statement in Magna Carta, and, in a different way, in the assertion at about the same time that feudal obligations in England did not include service in France-a claim which the recognized feudal law of the beginning of the century would not warrant. I would not insist too strongly upon the distinction between public and private law, for it is true that it does not exist in feudal in the same way that it does in other systems of law, that the feudal system is, as it has been called, a usurpation of the domain of public by private law; and yet, if the distinction is not pushed too far, it is useful and for certain purposes necessary. There is a sense in which the curia of the king, apart from the exercise through it of the prerogative, is a different thing from the curia of a minor baron, though no line of institutional difference can be drawn between them. On the charter of Henry I., see the article of Professor Henry L. Cannon, A. H. R., XV. 37-46. 


\section{ORIGIN OF THE ENGLISH CONSTITUTION}

height, is that which extends from the battle of Tinchebrai, in 1107, to the beginning of Henry II.'s attack upon the chief bulwark of baronial independence-the feudal court. If we are to give this last a specific date it should probably be that of the Assize of Clarendon, 1166, but the dates are not intended to be exact. ${ }^{23}$ Henry I. probably felt himself at liberty to do as he pleased after the failure of the baronial insurrection in 1101, or at least after the overthrow of Robert of Bellême, and if Henry II.'s direct attack upon the feudal court had not already begun before 1166, it had been clearly foreshadowed in the writ of right and other writs occasionally in use. In the development of the rights of the suzerain which followed the victory of Henry $I$. and which was thenceforth uninterrupted even by the compromise of the investiture conflict, all suzerains, the king's vassals with reference to their vassals, shared alike, so far as the advantage gained was financial, but the king's gain was far more important than any immediate increase of revenue. For him it was a transformation of the theory of Domesday Book of final royal ownership into a reality, not in the way of economic enjoyment, but of potential government. It meant the royal right of control, made clear and

23 One might assert for the date $\mathbf{1 1 6 6}$ as good a claim as for any in history to be considered a hard and fast boundary line, marking, as it seems to do with the beginning of Henry II.'s legislative activity, the exact dividing point between the first Anglo-Norman century, which begins with 1066, and the second, which closes with 1265 . 


\section{GENERAL INTRODUCTION}

enforced over all the land of the kingdom, and as the land was the basis of the feudal relationship and of the feudal services through which government was operated, it meant the final right of the king to determine how services should be rendered and how far other rights should extend. ${ }^{24}$ Without a clear perception by king and barons alike of the relation of the king to the land in whose hands soever it might be, the establishment of such a practice as scutage and the triumph of royal justice over feudal would have been more difficult.

The reign of Stephen is an interruption and a temporary reaction. The sort of feudalism which affected many other countries, baronial feudalism, separatist feudalism, instead of feudalism under strong central control and in the service of the state, had then an opportunity in the Anglo-Norman world. But the only serious loss which resulted was in the state's control of the church, and this was not entirely a feudal matter. So far as the feudal baron proper is concerned, Henry II. was able in a few years to reestablish completely his grandfather's

24 'This is to be regarded, I think, as the first increase of royal power after the Conquest which can be called constitutional, that is, in law and institutions. The failure of the attempts of the earls under William I. and of the more general insurrections at the beginning of the reigns of William II. and Henry I., together with the complete overthrow of the house of Bellême in England, no doubt strengthened the king's power in its practical operation, that is, they would make resistance and an appeal to rebellion less likely, but this cannot be regarded as a constitutional increase of power. 


\section{ORIGIN OF THE ENGLISH CONSTITUTION}

power and then to go on by means of it to develop the institutions of royal centralization and absolutism along the way his grandfather had pointed out but had not been able himself to follow to any permanent attainment. 


\section{GENERAL INTRODUCTION}

\section{Note A. The Limited Monarchy and the Constitution}

$$
\text { (Page 2.) }
$$

By the English limited monarchy is not meant merely a monarchy in which the king cannot do as he pleases. There have been many such in history, more or less permanent. The essential and peculiar character of the English Constitution is that the king has remained in theory and in the letter of the law absolute; he is still in form the source of all authority, the acts of the government are his acts, the officers of the state are his servants, while in reality, by various institutions, statute laws, and conventional practices having the force of law, he has been hedged about by limitations, and the true sovereignty, the final power of decision in all questions of importance, has been transferred to the people who form the nation and who act through their elected representatives. The constitution as a whole is made up of the institutions, laws, and practices through which the nation acts and expresses its will, but the one thing which gives unity and system to all these is the limited monarchy, or, to use the other term by which we commonly call it, the constitutional monarchy-a monarchy acting under a constitution.

When we speak of the English, or the Anglo-Saxon constitution in these days, using the words as a generic term, we refer, therefore, to that type of constitutional government which rests upon the sovereignty of the people, expressing itself through elected representatives, who in their corporate capacity as a legislature, hold under a strict control the executive authority which is nerertheless in theory very strong. That is at least the sense in which I use the term in the title of this book. It might be thought more accurate to say that $I$ am treating of the origin of the English limited monarchy, since it was by the evolution of that feature that the institutional history of England was turned into a road of its own and all the peculiar features of the constitution either brought into it, or kept from disappearance. But if we once undertake to separate the distinctive features of 


\section{ORIGIN OF THE ENGLISH CONSTITUTION}

the English Constitution which are due to the development of the limited monarchy from those that are not, we shall find so little of essential importance left in the second class that it will hardly seem worth while to make the distinction. The English Constitution, as something different from other constitutions, is marked by a strong monarchical or executive authority limited by the ultimate sovereignty of the people vested in the legislature, and that is what we mean by the term when we use it with discrimination. It is indeed true that an extreme expression in constitutional form of the principle of the sovereignty of the people is to be found in those limitations upon the right of the legislative assembly which are embodied in the constitution of the United States and in many state constitutions as well. And it appears to me certain that it is from this limitation of legislative right that there has been developed, as a practical matter, that peculiar feature of the American unwritten constitution, the power of the judiciary to declare laws regularly adopted to be void because unconstitutional, though such a development was made easier by a natural tendence of a similar sort from early times, as has been so ably shown by Professor McIlwain in his High Court of Parliament. But although the United States has gone beyond the English model, the result is only a logical development of English fundamental principles and requires no modification of our definition. The American constitutions with these features included are Anglo-Saxon.

In this book the term refers to the national constitution only. The local constitution is necessarily excluded, and properly, since under this type of national government any kind of local constitution is possible, from the centralization of France to the American federal system with the complete independence in some particulars of the state governments and even of the smallest local unit. There will be found here then no discussion of local institutions in themselves, though at many points they are necessarily involved in the history of national institutions, and unless the contrary is specifically indicated conclusions refer to national rather than to local government. 


\section{GENERAL INTR.ODUCTION}

The construction of this constitution is also to be considered the great achievement of English history, for the Empire, which probably should be placed beside it as an equally great creation, is to be reckoned British rather than English. But the limited kingship is the work of England alone. It may be called also without too great exaggeration, if not the greatest, one of the greatest political achievements of any race or time. The opposite transformation, which occurred in Roman history, by which a republic, while retaining the name and forms of a republic, was changed into an absolute monarchy, gave rise to a government and a system of law which for centuries exercised the most profound political influence at work in the civilized world, and is even today a powerful force. But the type of constitution which England evolved, as new to human experience as was the Roman in the first Christian century, has been copied more or less closely through vastly wider regions than the Roman. Whether it will be as permanent an influence measured in centuries remains of course to be seen.

It may be added that the English Constitution, in the form in which it began to influence races other than our own, was the product of a long and slow growth. It was not struck out at a blow nor made by the effort of any generation. If we look back over the whole life of the English nation to the Norman Conquest, that is, to the date when the last of the constituent elements of the nation entered and took its place beside the others, we are struck by its steady and continuous character. There were no revolutions which deflected the current of the history. Revolutions occur in plenty, as frequently perhaps as in the life of any people, but what they do is to clear the channel of obstructions, as in the seventeenth century, not to change the direction of the stream. The revolution over, the work of constitution making is found to be going on as it was before only with greater freedom, with something out of the way which had held it back. Epochs we can mark out in this process of growth, but we do it rather by noting differences after long periods than by finding sudden advances or instantaneous changes. 


\section{ORIGIN OF THE ENGLISH CONSTITUTION}

In a growth so uninterrupted, scarcely to be detected at any given moment and intimately a part of the nation's life, the question of origins is one of great difficulty. A beginning is hardly to be found, or a point where one can say with certainty, here enters this thing which is new and which makes all that follows different. Beginning is transformation, and where the moment of transformation occurs can be detected, if at all, only by the most careful scrutiny which searches forward and backward from the ends of an epoch and examines principle as well as form in what is changing.

\section{Note B. ANglo-Saxon Feudalism and Political axd Economic FeUdalism}

$$
\text { (Page 18.) }
$$

Os Anglo-Saxon feudalism in general, I would refer to my article in the American Historical Review, VII. 11-35 (1901). The purpose of that article seems to have been misunderstood by some at least who have written me privately in regard to it. As virtually stated in the note on page 16 , it was not written with the intention of making an original contribution to our knowledge of the subject. My command of the materials necessary for the purpose was and is too limited to justify such an ambition. The article was intended merely to call attention to the fact that no evidence had yet been brought forward to show the existence of institutional feudalism proper in England down to the date of the Conquest. No evidence has been produced since it was written to change the opinions there expressed. To my mind the two strongest pieces of evidence which have ever been used to show the existence of real feudalism in Anglo-Saxon times are the oath of a man to his lord, Liebermann, Gesetze, I. 396, No. 1, and Bishop Oswald's letter, Kemble, Codex Diplomaticus, VI. 124; Birch, Cartularium, No. 1136; Penn. Transl., IV. 8; cf. Maitland, Domesday, pp. $304 \mathrm{ff}$. I leave one side the question of the authenticity of this letter. See Round, Victoria County II istory, 


\section{GENERAL INTRODUCTION}

Worcester, p. 250. The first of these documents implies a relationship between the lord and his man very closely parallel to that which existed in early stages in the development of the vassal relationship in the Frankish state, in that shown by the patrocinium formula preserved in the Form. Turonenses, No. 43 (Zeumer, I. 158; Rozière, I. 69; Penn. Transl., IV. 3), for example. While I think it can be shown that the Saxon form is fully accounted for by a development of primitive German ideas, and that no supposition of Roman institutional influence is necessary to account for it, the differences implied concern rather the relation of the whole institutional situation of which it is a part to the general government than the practical results as affecting individuals. If any one should be disposed on the basis of these two formulas to identify the Saxon and the Frankish practices in their immediate personal results, there would be no serious objection that could be made. To apply the word vassal to the Saxon relationship would not be inaccurate, for it is used of equally undeveloped relationships in the Frankish state. The only valid objection to its use is that to the mind that does not make distinctions it is likely to imply more than is intended.

As to what is implied in Bishop Oswald's letter, there is no necessity of conceding even so much. That leases like those described in this letter, and the resting of military duty upon the land, as described in the customs of Berkshire in Domesday, I. 56 (Stubbs, S. C., p. 91), created a condition of things which could very easily be transformed into a true feudal arrangement, is one thing; that the arrangement was in itself truly feudal is not apparent.

As I have said in the text, it is this that we can say, and the most that we have any right to say, that there existed at the close of the Anglo-Saxon period, a condition of things which could be very easily and naturally transformed, with no sense of violent change, into a true feudal organization of the state. If such a feudal organization had existed under Edward the Confessor the evidence of it, in the amount of Anglo-Saxon material which we possess, would have been so clear as to admit of no question. 


\section{ORIGIN OF THE ENGLISH CONSTITUTION}

It is, I believe, no more than this which Professor Vinogradoff means when he says of knight service that its roots run back into Saxon times, The Eleventh Century, p. 79. But the phrase is open to the same objection as that suggested to the use of the word vassal. It seems to imply that knight service grows out of some Saxon relationship as one of the sources of its being. Such an interpretation would be, I believe, incorrect. The roots of knight service in that meaning run back into the Frankish empire and into that only. If the metaphor had been that of resting for its foundation in part upon Saxon customs, there could be no objection to it.

To put the matter in another way: Maitland and Vinogradoff have shown clearly and in many details the drift towards practices of a feudal character in Anglo-Saxon England. Their studies make it certain that, on the side of economic arrangements, the organization of agriculture, the development of lordship over the cultivating class, the absorption of smaller in larger estates, a steady current set towards the manorial system. Deferring for the moment the question of the survival of Roman manorial forms, it is not necessary for us to take sides here upon the other question as to what extent they served as a model in AngloSaxon changes, nor to say how far an exact manorial system, according to the pattern of the twelfth century, had come into existence before 1066. If we accept the views of Vinogradoff rather than those of Seebohm on these matters, we only make the changes produced by the Conquest more extensive and wider, and somewhat analogous on the economic side to those on the political. On the other side of feudalism, the political proper, these studies have also shown, particularly those of Maitland, many practices becoming established in Saxon England which border closely on political feudalism and are parallel to practices in the Frankish society of the Carolingian age when feudalism was forming. The growth of private jurisdiction, the association of military service with land, and the possible transfer of the responsibility for military service to the tenant in land leases, appear at first sight to show as steady a drift towards political feudalism as facts of the 


\section{GENERAL INTRODUCTION}

other kind towards economic. A careful study, however, of forming feudalism in the Frankish state makes it evident that the peculiar economic and political conditions which prevailed over Europe from the fourth century to the tenth produced a number of groups of peculiar institutional forms adapted to meet the more or less permanent needs of different sorts which arose from those conditions, and often in appearance closely related to one another; that some of these forms speedily perished; that others survived and passed on to later times; that among those surviving was one group of institutions which, by the importance of the relationships and of the classes which it primarily concerned, at once obtained a controlling position in the age that followed its origin, drew under its influence and moulded into a great system the other institutions that had survived like itself, and stamped its impress upon all the features of an age which we call the age of feudalism because this dominating and controlling element was the feudal system proper, the system in which the fief was a fundamental element. Nothing which belongs in this main line of feudal development has been shown to exist in Saxon England with the possible exception of the man's oath referred to above.

Private jurisdiction which, considered as manorial and public jurisdiction, is one of the things adopted from outside by forming feudalism, not created by it, finds, for instance, one of its most common sources in the disciplinary power of the lord to keep order and settle disputes among his unfree tenants, an outgrowth of his economic position. As the manorial system derelops, this power increases in importance, and draws by degrees under itself the free inhabitants within the lord's territory and begins to have a political aspect in one regard. At last when the estate had absorbed all or nearly all of the hundred, it may very likely have seemed absurd to maintain two separate courts for the same community, or perhaps more accurately, it seemed the simplest and most natural thing to do to transfer to the lord in form the responsibility for the public jurisdiction of the hundred which was already almost all in his hands in practice. This brings together clearly in Saxon times two of the 


\section{ORIGIN OF THE ENGLISH CONSTITUTION}

three distinct types of private jurisdiction of the feudal age, the manorial proper, chiefly economic in character, and the public jurisdiction of the smaller territorial divisions, transferred to private hands, but not thereby changed in character or scope. Of the existence of the third type in Saxon England, the feudal jurisdiction proper, as that is defined by the feudal codes, no particle of evidence has ever been produced so far as I know. The same thing is to be said, I think, of the other practices which constitute institutional feudalism proper. Or, if any one objects that this is too strong a statement considering the admissions made in the first paragraph of this note, it can at least be said that no evidence has yet been produced which compels us to admit the existence in Saxon England before 1066 of institutional feudalism proper in anything beyond the early stages of its derelopment. Many generations of growth would have been needed, barring the sudden stimulus of outside influence, to bring the customs of which we know anything into such a stage of union and of maturity as the feudalism of the Conquest displays. For evidence of the continuation in the Frankish Empire on into a time when feudalism proper was taking on its final form, into the tenth and eleventh centuries, of the great variety of closely allied forms of land loans, partially economic and partially political, which characterize the earliest periods of forming feudalism and lie all about the direct line of its descent, see Seeliger, Die Soziale u. Politische Bedeutung der Grundherrschaft im Früheren Mittelalter, in Bd. XXII. d. Phil.-Hist. Klasse d. K. Sächsischen Gesellschaft d. Wissenschaften, and separately, 1903.

In regard to the origin of the manorial system it may be added that since the work of M. Fustel de Coulanges was published in its final form in a volume entitled L'Alleu et le Domaine Rural in 1889 , much attention has been given to the subject by European scholars. The result is that, while we can say that M. Fustel de Coulanges assigned a larger share in producing the results he described to certain economic forces than his predecessors had done, the newer studies have shown the operation of influences of like kind which he overlooked, and tend to modify his conclu- 


\section{GENERAL INTRODUCTION}

sions in some important ways. The results of the new studies have been fully presented to English readers in Professor Paul Vinogradoff's The Growth of the Manor (1905). This book is likely, however, to give the reader the impression that M. Fustel's conclusions must be more seriously modified than really is the case. It has been, I think, clearly shown that he allowed relatively too large a share in the final product to legal factors, and that he fixed the date at which the manorial system had taken possession of practically all the soil somewhat too early. But it should not be overlooked that nothing in the new studies tends to prove that the influences upon which M. Fustel laid the greatest emphasis did not exist as important elements of the situation, or to show that they did not produce the results ascribed to them. The legal and institutional factors must still be allowed large share in the final product, only we must recognize that that product is a resultant of a larger number of forces than he took into account and that consequently it must be described in somewhat different terms and with somewhat different emphasis. Nor has anything been produced to show that the manorial system was not in existence with all its essential features under the Romans; what has been shown is that it by no means occupied all the soil in the early periods of feudal growth, but that systems of agricultural organization of essentially different origin existed alongside it, especially the system of the village community, and that these different systems were especially features of the country in Britain. It must also be noticed that the evidence for the new conclusions is much less in amount and considerably less definite than the legal and institutional evidence. The new investigations also are to a much larger extent dependent upon inference for their results. I do not intend to imply that the evidence is insufficient or the inferences not well founded, but merely that to contemporaries of the fall of Rome this side of things did not bulk so large, that these influences were more unnoticed and escaped the records except here and there. Personally the evidence is satisfactory to me. I have never been able, for instance, to accept M. Fustel's interpretation of Title XLV. of the Salic law, which 


\section{ORIGIN OF THE ENGLISH CONSTITUTION}

seems to me to show clearly the existence of the village community alongside the manor. The best of the more recent accounts of these relations which accepts the conclusions of M. Fustel de Coulanges is See, Les Classes Rurales (1901). See M. Esmein's most recent expression of his views on some of these points, to be included in a new edition of his Histoire du Droit Français, in the Nouv. Rev. Hist. de Droit Français et Étranger, MayJune, 1911, pp. 331-347.

I may add that to me it appears that a failure to make clearly the distinction between economic and political feudalism is, in part at least, responsible for a somewhat distorted view of the character of Anglo-Saxon feudalism. The drift in Saxon England towards feudalism on the economic side was so much stronger and the results reached were so much more nearly final that, unless one sees clearly that institutional feudalism proper did not originate in such arrangements, more definite language may easily be used than can successfully be defended. If one looks only to the economic and the social, and lays little emphasis on the strictly legal and institutional, or if one holds that identity of practical result implies identity of institutional foundation, it is easy to believe that the essentials of feudalism proper existed in England before 1066.

That the terms political and economic feudalism, which I used for this distinction in Vol. II. of The Political History of England, pp. 14-19, are open to objection, I am fully aware, but I know of no names in which the distinction may be expressed which are not. In my article on Anglo-Saxon feudalism in the American Historical Review referred to above, I used the term feudalism proper for the political side. The French writers, who have drawn this distinction more clearly than any others, have uscd the term seigneurial or domanial for the economic side and vassalic or feudal for the other. Says Ferdinand Lot in a book review: . . . la confusion inattendue de la part de l'auteur,entre la régime domanial et le régime vassalique (je n'emploie pas le term féodal que prète à toutes sortes de confusions). Le premier n'entraînait pas forcément le second, bien qu'il le 


\section{GENERAL INTRODUCTION}

préparât merveilleusement. Moyen Age, VI. 25. J'appelle régime domanial tout l'ensemble d'institutions sociales qui marquent les relations du seigneur propriétaire avec les paysans de toute condition qui cultivent la terre. Il convient de le distinguer nettement du régime féodal, qui designe les rapports de vassalité entre propriétaires, rapports de nature plutôt politique que sociale. H. See, Séances de l'Academie, CLI. 508 (1899). See further, See, Classes Rurales, pp. 22-27, 104-107, 110, 302; Esmein, Histoire du Droit Français, pp. 211-212.

These are, I think, less satisfactory terms than political feudalism, which expresses clearly enough what was the chief purpose, the determining characteristic of this side of the feudal system, and economic feudalism which does so of the other side. The chief objection to these terms is that on one side certain functions which are plainly enough political, like local police jurisdiction, or even an entire local popular court, seem to get inextricably mixed with the economic organization, as if they really belonged in it, and historically the mixture actually does take place in some cases before the advent of political feudalism. On the other hand, also, such money payments as reliefs and aids belonging to political feudalism seem at first glance to have an economic character, though we readily enough recall the fact, indicated by Magna Carta, c. 2, that reliefs from t'se same feudal unit, the barony or the knight's fee, are equal without reference to the size or value of the holdings among themselves. Carefully considered, neither of these considerations is, however, a real objection. Neither indicates a real variation of character in the system to which it belongs. They disclose, however, what is the most serious difficulty in getting an intimate knowledge of feudalism,- - the difficulty of being misled by superficial appearances, and until one can see through these and other like mysteries, especially until the mixture of jurisdiction is no longer a puzzle, there will always be some confusion of mind about the facts of feudalism. When this difficulty has been overcome, there will no longer be felt any fatal objection to the terms political and economia feudalism. 


\section{ORIGIN OF THE ENGLISH CONSTITUTION}

In the feudal system as it was practically operated, the point where political and economic feudalism came into contact with one another, the common foundation upon which both sides were built, was the domain manor. If we may be allowed to leave out of account a few exceptional cases, which do not affect the general condition of things, this aspect of feudalism may be described as follows. Practically every manor in England is a domain manor at some point, higher or lower in the hierarchy of fiefs, as itself forming a knight's fee or being one of the domain manors of a barony. As such, as a domain manor, the purpose for which it is held in hand and exploited is wholly economic. If it is a knight's fee, the income derived from it is what supports the knight and his family and enables him to fulfill his feudal obligations. If it is one of the manors held in hand by a lord higher in the feudal scale, the purpose of its retention and exploitation is to provide the income by which the baron may meet such of his military servitium debitum as has not been provided for by subinfeudation, may be able to perform his other feudal duties, and maintain his rank in the society of his time. The chief support which maintains the feudal world from the king down is the domain manor. But at the same time these manors form in one sense the unit, and in every sense the foundation, of the system of non-economic services and duties by which the business of government is carried on, that is, political services. The domain manor is in many cases identical with the knight's fee. As knight's fee it stands, however, in a quite different set of relationships from those in which it stands as domain manor, and this is equally true if it is one of the domain manors of a barony. It is from this other side not regarded as the source of income, but of military service, of the widely comprehensive court service, of certain specific aids, and of all that was meant by fealty. The tenant in receiving it assumed, not an economic obligation, but these services, and his lord in granting it expected from it assistance in meeting his obligations only in the matter of military service and of certain aids. He did expect, also, and one of the chief things he received was, increased political and social in- 


\section{GENERAL INTRODUCTION}

fluence and consideration from the possession of vassals. The economic returns of the domain manor must have been considerably more than the cost of the feudal services imposed upon it, or the feudal régime could not have been sustained. The simplest case is, of course, that in which the manor and the knight's fee are identical. Here it should not be difficult to see that the same manor is held at once in two different relationships, is explaited, if that term can be used of political feudalism, for two different purposes and in two different ways, and in general belongs at once in two different systems which have little in common, beyond certain superficial resemblances which admit of easy historical explanation, like the common idea of tenure by service, or the appearance of such feudal incidents as homage and relief attached to manorial holdings. See further The Political History of England, II. 14-19. The same distinctions could be developed from the separate origins of these two sides of feudalism, if this were the place to recount their history.

In attempting to understand the non-economic character of political feudalism, care should be taken not to be led astray by the economic interests which are so plainly appearing in English feudalism in the last half of the thirteenth century. They are no part of original feudalism but are results of the rapid social, economic and political changes which characterize that century as a whole. So pervading are these changes and so decisive in their effects, that evidence derived from the thirteenth century as to feudal ideas, and the contemporary interpretation of feudal institutions, and even as to their operation, must be used in the study of Anglo-Norman feudalism before 1215 with the greatest circumspection. To take a specific case, private jurisdiction both baronial and manorial, at least the latter in relation to the former, was so transformed, certainly in the way in which it was regarded and I think in the way it was operated, in the reign of Henry III., that the study of documentary material, at least of origin later than 1265, in order to understand private jurisdictions of the twelfth century would be worse than useless unless the feature under observation can be carried back practically unchanged 


\section{ORIGIN OF THE ENGLISH CONSTITUTION}

to an earlier date. In fact, the whole thirteenth century had better be left out of account entirely until one has obtained a thorough knowledge of what Anglo-Norman feudalism was before the accession of John. I may be allowed to add that in my opinion to begin at the modern end, among the survivals of feudal practices, and to work back into the age of true feudalism, is almost necessarily fatal to any accurate understanding of its details. Such a process certainly entails many misconceptions and wrong interpretations which are very likely never to be perceived and which can be corrected only with great difficulty. The feudal is preeminently a period of institutional history which can be safely studied by one who would understand it as it understood itself, only from the age of origins on. 


\section{CHAP'TER II}

\section{Institutional Introduction}

The machinery of the Anglo-Norman state for carrying on the general government of the country during the first century of its existence was simple in the extreme. Differentiation of the functions of the state, like the legislative and the judicial, had not yet begun either in the ideas which men had about their government, or in the way things were actually done, and a single, simple set of institutions sufficed to carry on all public business from top to bottom. To the operation of these institutions there were indeed numerous local and special exceptions, like those, to cite one example, which resemble the Carolingian "immunity," known technically in England as the "liberty"; but though important in the individual case, no one of these exceptions had any significance as a real variation or break in the machinery of government. The government in general was conducted as it would have been if they had not existed. There was, however, one source of exceptional institutional action, lying outside of what we may call the normal machinery of the state, which was of the utmost importance, rather in the possibility of development which it presented for the 
future than from any immediate result-the royal prerogative. But during the century which I think should be regarded as introductory to the age of growth, there was no development of the possibilities of the royal prerogative into anything like a connected system. At least if such a development had taken place the evidence of it has not come down to us, and whatever may have been accomplished by such a development was not permanent. Considerable growth occurred during the first century in the way of beginnings and of preparation, as we shall see later, and while the evidences of this early growth which we find surviving at the beginning of the reign of Henry II. might possibly be the fragmentary remains of a system which had gone to pieces, their aspect is rather that of experimental beginnings. The action of the prerogative is on the whole isolated, in individual cases, and it therefore presents, like the liberty, no real exception to the simplicity of the Anglo-Norman government.

Of this Anglo-Norman state during its first century by far the chiefest, the central, unifying, allperforming institution was the curia regis. It was not the only institution of general government. A large part of the detailed work of carrying on the business of the state was not immediately performed by it. But all was subject to it. All officers were responsible to it. $\mathrm{By}$ it the old was maintained and enforced and whatever innovations were made were 


\section{INSTITUTIONAL INTRODUCTION}

approved and confirmed. By its counsel and advice the king acted in questions of policy, domestic and foreign, and by its judgment disputes as to the application of the law or the ownership of property were determined. No question arising or fact occurring in the field of government, or of the private interests of the ruling class, was outside the sphere of its competence.

The curia regis, or king's court, was an assembly court. Like the Saxon witenagemot, or the Carolingian king's court, which may have been its immediate ancestor, it included in its membership all the chief men of church and state. Unlike them, however, or unlike the Carolingian king's court until feudalism was well established, ${ }^{1}$ the position which a man held in the public life of his time was not the determining factor of membership in the court. Its institutional basis, its principle of composition, was different; it was now the vassal relationship to the king which determined membership. The court was the assembly of the king's vassals, and its members were present, as Henry II. told the bishops in one of the clearest statements of the institutional principle of the court which the literature of feudalism anywhere gives us, because they were the king's vassals. ${ }^{2}$ They were performing one of the most

1 Dahn, Koenige der Germanen, VIII. 4. 32.

2 The Constitutions of Clarendon, c. XI. Compare with this the following: Et establi à estre juges de la Haute Court ses homes chevaliers qui li 


\section{ORIGIN OF THE ENGLISH CONSTITUTION}

important of the services to which the vassal bound himself when he entered into that relationship.

When we have said that the normal principle of the composition of the curia regis was feudal, as it undoubtedly was, we have not stated the whole case. Here at the very beginning of our study of the constitution we are brought face to face with the exception in the systematic organization of the state which is the starting point of change, the prerogative of the king. The king was in and of the feudal system and was its head. He was the highest suzerain, the lord paramount of all the vassals and of all the land of the kingdom. But he was more than this. From some source, from what we are only given hints, possibly from traditions or reminiscences of the Carolingian monarchy, possibly by some actual inheritance from it, with possible reinforcement from ideas of the Roman imperial authority, and with certain reinforcement from conceptions of the Old Testament monarchy, ${ }^{3}$ there existed, if it is too much to say a theory of the king's function in the state, certainly a practical conception of it which is definite enough and which was a vital seed of growth. It was the

estoient tenus de fei par l'omage qu'il li avoient fait. Assises de Jerusalem, Livre de Jean d'Ibelin, c. II., ed. Beugnot, I. 23. See the citation in the last paragraph of note $C$, at the end of the chapter (p. 105).

${ }^{3}$ See Luchaire, Inst. Mon. de la France, I. 41-43; Flach, Origines de L'Ancienne France, III. 357-359; Liebermann, Ueber die Leges Eduardi Confessoris, p. 63; Poole, Illustrations of Medieval Thought, pp. 235236. Cf. the precedents of Saul and David cited in the Song of Leves, 11. $446-448$. 
business of the king to be a "Lion of Justice," to make order and security prevail, to protect the helpless and the weak, the widow and the orphan, the church, the merchant, the $\mathbf{J e w}$, any one who stood in need at the moment, from the constant danger of oppression in those turbulent times. More than this, it was not so much his duty to afford such protection in individual cases as they arose, as to maintain in his kingdom such a state of order as to render it impossible for the powerful neighbor to yield to the temptation of injustice when the opportunity offered-such a state of order that, as contemporaries often expressed it, a woman, or a man with his arms full of gold, might go in safety, though unprotected, from one end of the kingdom to the other. The king as a man, the kingship in its ordinary operations, might be feudal, intricately involved in feudal processes and ideas, so that the sovereign might seem lost in the suzerain, and the whole surface aspect of the state be feudal, as it surely was, but the king must still dominate feudalism, he must be master of his feudal baronage. The king who could do this was the good king, "the Lion of Justice"; the king who could not do it, either from some defect of personal qualities, or from the special conditions of his time, however lovable he might be personally, or how truly a man of energy, and Stephen seems to have been both, was a bad king "who did no justice."

Now in practical operation this side of the king- 
ship shows itself in a number of acts, powers of action we might say in the abstract, prerogatives, which do not come from feudalism, and for the exercise of which the feudal system does not provide. A discussion of their relation to feudalism, whether they are anti-feudal or not, does not belong here. Here it suffices to note that they are non-feudal. From what source they actually came to the Anglo-Norman kings it is not possible to say with certainty, but their similarity in specific operation all along the line to corresponding actions of the Carolingian kings is so striking that the temptation to derive them from that source, even in the absence of connecting evidence, is almost irresistible.

More important for our present purpose than an identification of the sources of the Anglo-Norman king's prerogative is it to insist upon the utmost necessity, if one would understand the AngloNorman state even during its first century, and still more during the century of change which follows, of giving due weight to these two contemporary and coactive sides of the kingship-the feudal and the prerogative. The government was carried on mainly by feudalism. Government processes, government machinery, prevailing ideas and interpretations, the air and aspect of all, was feudal. But to carry out practically his supreme function of maintaining justice in the state, the king was recognized as possessing certain rights and powers not contained in any con- 
ception of the suzerain, and at any moment he might interpose to do something which the feudal law did not provide for, for the source and justification of which he virtually called, he would have called had he reasoned about his action, upon a different conception of the state from the feudal. It is the operation together of these two, feudalism and prerogative, which characterizes the constitution of the first century of the Anglo-Norman state; it is their rivalry, their struggle for a supremacy which neither in the end gains, which is the key to the constitutional history of the second century, and in one sense this it is which gives rise to the English limited monarchy.

In the membership of the king's court, as has been said, the action of these prerogative powers is occasionally to be seen-is perhaps always seen in one essential element of the court's composition-the official element. It was of course a principle of the feudal law that the vassal performed any given service due from him only on special summons for each occasion. Ordinarily no one attended a session of the court who had not been asked to do so. But the feudal law provided in no way for the attendance of the non-vassal. Yet it seems clear that the king had the right to make persons whom we cannot show to have been his vassals full members in the court with the same voice in making up its final decision as any of its members. Cases of the kind are not uncommon-the queen. the king's sons, visiting potentates lay and ecclesiastical, 


\section{ORIGIN OF THE ENGLISH CONSTITU'TION}

the papal legate, even the king of another state. ${ }^{4}$ One class is here of particular importance-the permanent officials of the king's court and household. They formed in all probability a most influential element in every session, with special knowledge of business and precedents and with a special responsibility for the king's interests, a more permanent element than the ordinary baronage might be, an element continuing with regularity from session to session and proportionately of still greater importance in those slightly attended sessions of the court which fell in times between the great assemblies and must have been the chief dependence of the time for the everyday details of governmental business, and yet notwithstanding their evident importance in the curia

4tubbs, I. 386; Petit-Dutaillis, Louis VIII., pp. 344-345. A rather typical case was the Easter "generale concilium," held by Stephen in 1136. It contained the two archbishops, eleven bishops of England and Wales, the archbishop of Rouen and four Norman bishops, the king's nephew, Henry, afterwards Count of Champagne, and the son of the king of Scotland, the chancellor, two constables, two chamberlains, a dapifer, a butler, three earls and six barons Madox, I 13, s. See Round, Geoff. de Mand., p. 16, and $\mathrm{cf}$. the commune consilium of 1218, Rymer, I. 152. Such enumerations may not be complete, but they include certainly all important names. To the council of 1164, trying Thomas Becket, the king called certain sheriffs et secunda dignitatis barones, antiqui dierum, ut addantur eis et assint judicio. Robertson, Materials, Rolls Series, III. 67. The same writer, William Fitz Stephen, who knew the law rather well, seems to think the chancellor had a right to attend eren if he was not summoned. Ibid., p. 18. The anonymous author, referring to the same curia, makes also a very good statement of the different elements united in a great council. Ibid., IV. 41. The queen or the king's sons are frequently named as present at a curia and often witness its action. See Round, Cal., Nos 78 and 1190. On the presence of the legate see Bracton's $N$. B., pl. 1273. 
no emphasis is placed upon the fact of their vassalage. No attention was paid apparently to the question whether they were vassals or not; but the essential point was their official character. As a matter of fact they were no doubt in all cases during the first century connected with the king by feudal homage and fealty, ${ }^{5}$ and yet also without doubt the king had the power to give them full standing in the court whether they were or not. Later when differentiation had begun in the curia regis and questions of the extent of the competence and jurisdiction of some of its branches arose because they were rapidly taking on a less feudal and more official character, it seems clearly to have been assumed that the official justice was the peer of the feudal baron, until the king was forced by the barons to admit exceptions in some cases. Such an assumption in regard to a justice who was an official only, and not a vassal was certainly contrary to feudal law, but with equal certainty not beyond the competence of the king's prerogative. This question, however, did not arise in the first century and during that time the curia regis was composed of the baronial element, as summoned to attend, and without objections of any others whose presence the king desired. ${ }^{6}$

5 If by no other, then by a serjeanty tenure by which they might hold the lands which served as the endowment of their office, but this as a feudal, though not strictly a military tenure, would be sufficient to meet any objection that might be made on grounds of strict law. See chapter V., note 30.

6 Probably when the question did arise, the real objection of the feudal 


\section{ORIGIN OF THE ENGLISH CONSTITUTION}

'The curia regis was not merely an assembly court in composition; it was an assembly in the way in which it did its business. Its presiding officer, often in practice and always in theory the king himself, was a moderator only, not a judge. The decision was formed, the judgment was made, by the prevailing opinion of the membership at large, and in this the king in form had no share though it is difficult to suppose that his known wish should not have had great influence, particularly in the non-judicial action of the court. In form, however, he had no voice. A lawsuit in which he had a direct interest could be fairly tried by the court over which he presided. The decision of the court was usually formally stated by some one of its members, but it did not become legally valid and compulsory until it had been officially proclaimed as its decision by the moderator. It is clear that such an official sanction might be withheld by the king if for any reason he thought best to do so. ${ }^{7}$ He was not

class was not so much to the fact that the individual justice was not technically a vassal, as to the fact that he was so thoroughly an official as to be professional, with this added that in many cases he had risen from a non-baronial class. What they wished to retain in cases where they wished to retain anything was the right of the baronial class as a class to settle questions affecting its own members. They were clearly right, however, in feudal law.

7 The distinction between the action of the suitors of the court in making the judgment and that of the presiding officer which gives it legal validity by proclaiming it as the judgment of the court, the distinction between Urteilfindung and Rechtsgebot, is established by abundant evidence and noted by secondary authorities generally, but it seems never to have been fully apprehended and logically applied by students of English institutions. See Brunner, Deutsche Rechtsgeschichte, I. 203 (1906), 
bound by the action of the court and might act against its advice, though he would do so in extraordinary cases only, and probably never when its action was judicial.

The king's court, as an assembly of all the vassals of the kingdom, met regularly, as had both the court of the Norman duke and the Saxon witenagemot, on the three great church festivals of the year, Christmas, Easter, and Pentecost. These were the great assemblies, called magna concilia, and they were all the meetings that were regularly provided for in the constitution of the first two Norman reigns so far as we know. It is evident, however, that the distribution of these meetings throughout the year was very un-

II. 225-226 (1892); P. and M., I. 87, 535 ff. Maitland describes clearly and fully the function of the doomsmen, but nowhere, so far as I know, with equal fullness and clearness the Rechtsgebot. The distinction is illustrated as numerously and as perfectly in the English sources as in those of any country. Especially good examples come to us from the reign of William I. From about 1071: Hujus placiti multis testibus multisque rationibus determinatum finem postquam rex audivit, laudavit, laudans cum consensu omnium principum suorum confirmarit, et ut deinceps incorruptus perseveraret, firmiter præcepit. Bigelow, Placita, p. 9, from Anglia Sacra, I. 336. From 1076: The most victorious King William approved and confirmed this decision, commanding that it should be set forth in writing, and gave it validity forever by these words . . . . Round, Cal., No. 712. From 1050: "It was decreed and decided by all the above-named judges, and confirmed by the king's command and authority." Ibid., No. 78. See also Memorials of St. Edmund's Abbey, I. 348, a case in 1081. The Abingdon Chronicle, II. 187, states what was thought to be a reason for the practice in a case arising early in the reign of Henry II.: Dicebant quippe solidius posse subsistere quod ex ore regio prolata auctoritas studuerit confirmare. Bracton at the beginning of his Treatise, f. 1, draws the distinction exactly in legislation: Sed absurdum non erit leges Anglicanas (licet non scriptas) leges appellare, cum legis vigorem habeat, quicquid de consilio et de consensu magnatum 
even. It is also evident that a central institution so intimately associated with all the operations of the government could not serve its purpose in the state with three meetings only and these in the first half of each year. ${ }^{8}$ We know that meetings were held at other times, on special summons by the king, or on occasions when some other reason, like a campaign or a coronation, brought the great body of the vassals together. But even with these additional sessions the government would be inadequately served. In the reign of Henry $\mathbf{I}$. there comes into sight a small curia, bridging the intervals of the larger and acting with all its powers, trying cases, supervising the sheriffs' accounts and receiving and caring for the king's revenues. Of such an institution we get glimpses in

et reipublicæ communi sponsione, auctoritate regis sive principis præcedente, juste fuerit definitum et approbatum. Probably procedure in judicial action was much more formal and prescribed than in legislative, but in general the same principles hold in both cases. Brunner notices, 1. c. II. 226, the occurrence of lax forms of expression which confuse the different functions, and such expressions were probably more frequent in accounts of legislative than of judicial action. Even in formal documents the action appears as that of the king "by the counsel and assent" of his barons because its actual legal validity comes from its formal acceptance and promulgation by him.

8 At whatever time the Exchequer became definitely established with a fixed accounting at Michaelmas, for the final statement of the year's business, something like a fourth meeting of the great curia may be counted. The Exchequer was a small and not a great curia, yet by bringing all the sheriffs of England together, and many interested persons besides (see Madox, II. 244-247), it nevertheless served some of the purposes of the great curia more truly than an ordinary meeting of the small curia. Probably the Michaelmas Exchequer accounts for the frequency of meetings of the great council on October 13, in the reign of Henry III. 
the earlier reigns, and we shall be doing no great violence if we assume its existence from the beginning, with less definiteness perhaps and fixity of position than it had later, but with no less powers, practically in permanent session and looking after the daily details and daily questions of the ordinary running of the government. Its membership would be from the first what it was when we get clearer evidence of its existence-household and court officials as its permanent core, and such persons from the body of the baronage as might be in attendance on the king, or present with him for any reason. The relation of the smaller to the larger curia, a relationship not easy for the modern mind io comprehend but one that must be seen if the operation of feudal government is to be understood, cannot be here considered in detail. ${ }^{9}$ There should be noticed what cannot be too often repeated that the smaller was not a committee of the larger, vested by it with certain duties; it was the larger with all its rights and powers. Whatever the larger could do, the smaller could do also. It differed from the larger merely in the number of those attending. There is one curia regis of the Anglo-Norman state expanding and contracting, and expanding and 9 See Political History of England, II. 18-20, 182-185; Stubbs, I. 406407; Maitland, Constitutional History, pp. 60-64. The advance made by Maitland over Stubbs, due to his clearer perception of the feudal character of the Anglo-Norman government, is evident here, as well as the fact that he sometimes hesitates to make a completely logical application of feudal principles. See note $A$ at the end of chapter IV. (p. 186). See also appendix $\mathrm{I}$. 


\section{ORIGIN OF THE ENGLISH CONSTITUTION}

contracting again, as the year goes on, but always in whatever phase performing the same undifferentiated functions. If then we add together, as two phases of the same institution, the practically constant work of the smaller curia and the occasional sessions of the larger, bringing together in theory at least the whole ruling class of the country in one assembly, we have the unifying, energizing, supervising, and controlling institution of the Norman state.

This centralizing character of the curia regis is apparent not merely in the assembly, but in the bringing together into a single institution of almost all the business of the state, and is from our point of view its most essential feature. ${ }^{10}$ Legislation was not frequent in the feudal state but occasionally changes were made in law, or actual innovations, and these were made by the curia regis, as in the ordinance of William I. separating the ecclesiastical and temporal courts, or in the Assize of Clarendon of Henry II. ${ }^{11}$ The act of counsel in important affairs is more frequent and is also the function of the curia as in the advice to William the Conqueror at Berchamstead to accept the offer of the crown; the refusal of the request of William II. that Anselm should no longer be recognized as archbishop of Canterbury; the approval of the second marriage of Henry $I$. The fact that they were not

${ }^{10} \mathrm{~A}$ good example of the miscellaneous business coming before a meeting of the great council may be found in the account of the meeting at Northampton, January, 1177, in the Gesta, I. 132-136.

11 See note $B$ at the end of chapter IV. 
consulted in the case of the marriage of the Empress Matilda to Geoffrey of Anjou was made a subject of complaint by the barons. The curia was also the one judicial institution for all cases affecting the crown, as in trials of treason like those of Roger and Waltheof, and of William of St. Callais; in trials for great failure of service and of duty as in the case of Robert of Bellême or Henry of Essex; or of other cases affecting fealty, faithful loyalty to the crown, as those of Odo, the king's brother, and Thomas Becket. But the curia regis was the one judicial institution also for the trial of cases between the vassals of the king, if the questions were important enough, or the rank of the parties high enough, to warrant its attention, and, though the Anglo-Norman king could not be directly sued, for petitions to the king for justice against himself in cases where a private man would be subject to suit. The administrative system was as completely in its hands as the legislative, conciliar, and judicial, first through its direct supervision of the details of feudalism, for besides the great assemblies which several times a year brought together certainly all the great vassals into immediate contact with the king to be held by that mere fact to their dependence and obligations, it was here in normal cases that the right of the heir to his father's fief was recognized-homage and fealty performed, and investiture granted-and here complaints of inadequate performance of feudal obligations were made and 
settled, as in the question raised by William II. against Anselm on his return from the Welsh campaign. Through the performance of his duties in the curia regis, even more than by the fulfilling of his other feudal obligations, the baron became an intimate and very essential part of the operating machinery of the state, indispensable indeed to the performance of its functions. But the official administrative machinery proper was under the control of the curia also in all its lines through its supervision of all the officers who had to do with the general government, both those of the household and those of the counties. In a word, as has already been said, there was no function of the state, no line of public activity, no interest of the government or of the ruling class which was beyond the control of the curia regis or which could be withdrawn from its scrutiny. It was the one centralizing, unifying institution of the Norman state, supervising all government and bringing the feudal baron constantly into contact with law and authority. It is for this reason that the curia becomes, as the constitution unfolds, the mother of so many institutions and also why, on account of the unusually regular and logical growth of institutions in England, the principles of the curia explain so many of the seeming peculiarities and anomalies of the later English Constitution. ${ }^{12}$

The carrying on of the details of government from 12 See appendix I. 
day to day was, so far as concerns the general as distinguished from the local government, in the hands of the court and household. The chief of these in England were the chancellor with his staff of clerks, acting as the king's secretary, preparing and authenticating documents of all kinds, and attending to many details both of an administrative and judicial character, the most widely employed of the household officers; the marshal and constable, having special responsibility for military matters; the chamberlain, supervising the organization of the household and social court and its contact with those not directly belonging to it; the dapifer or steward, who, together with the butler, had oversight of the economic side of court and household and never became in England so important a political officer as in France $;^{13}$ and the treasurer, who received and accounted for the king's revenue. These were the principal officers in England and their ordinary functions. But they were often employed in other services for which the king might have need. It may be thought that there should be added to these for completeness of statement the king's justice, an office not regularly but occasionally filled during the first century, but one of increasing importance and always of great efficiency as an instrument of centralization. The jus${ }^{13}$ See L. W. Vernon Harcourt, His Grace the Steward and Trial of Peers, chapter I.(1907), and cf. A.H.R., XIV. 475. On the subject of the household in general see Round, The King's Serjeants and Officers of State, chapter IV. (1911). 


\section{ORIGIN OF THE ENGLISH CONSTITUTION}

tice belongs, however, upon the side of the king's prerogative and not of the normal governmental machinery, and must be there more fully considered.

To complete the account of the normal machinery of the central government, there must be added the local organ of centralization, the sheriff. Whether the Anglo-Norman sheriff of the first century owes more of the meaning and efficiency of his office to Saxon or to Norman ideas may here be left unsettled. From whatever source derived, or from both, the office was a most efficient means of centralization, carrying the king's authority into every locality and the watchful supervision of the curia regis, so long at least as the not easy problem of holding the sheriff himself under effective control was solved. It is to be said that almost always in the Anglo-Norman state it was solved and the sheriff of the first century comes nearer than the Carolingian count himself did through long periods of Frankish history to realizing in practice the idea of that officer as the local organ of the central government. Indeed the Norman sheriff gives little trouble by his independence of control, though he was usually a great baron of the locality. There are some cases of hereditary sheriffs in England, as there had been a number of hereditary viscounts in Normandy, but this danger to the central power never developed to any extent north of the Channel, and was apparently soon checked in the duchy. It would seem to be quite possible that in the case of the viscount we 


\section{INSTITUTIONAL INTRODUCTION}

have one of the places where the Conquest reacted to increase the power of the duke in Normandy and to bring about a more effective local administration. Nor did the practice of which there are occasional instances of joining the shrievalties of a number of counties in a single hand prove dangerous; it is rather evidence of the king's confidence in his control. There are a number of cases where inquiry is made into the conduct of the sheriffs, and they are removed from office in consequence, notably in the great inquest of 1170, at which time two thirds of all the sheriffs were removed, but so far as the evidence allows us to judge, in all cases probably, and certainly in 1170 , these are not instances of the vindication of the royal authority against the effort of the sheriff to make himself independent. They are proofs rather of the reality and completeness of that authority, for the sheriff was removed for going beyond his rights and abusing his powers not to the detriment of the king but of the people of the county. ${ }^{14}$

In function the shrievalty is as undifferentiated an institution as the curia regis. It may be said in a word that it was the duty of the sheriff to see to the doing of everything which the central government wished done in his bailiwick. He was the ordinary local justice, presiding regularly at the trial of certain cases in which the central government had an interest, 14 See Inquest of Sheriffs, I., Stubbs, S. C., p. 148; Florence of Worcester, II. 138 . 


\section{ORIGIN OF THE ENGLISH CONSTITUTION}

and receiving special orders to attend to others. The first century after the Conquest is the climax of the sheriff's function as the local representative of the general judicial system. He was also the local administrative and executive officer, responsible for the enforcement of existing law and the maintenance of order, arresting offenders and holding them for trial, and in this capacity also receiving special orders from the central government. He was the local financial officer, collecting both ordinary and extraordinary revenues, fines, and dues, and responsible to the curia regis for the payment of a fixed sum each year from his county, called its fern. He was more than an ordinary financial officer, because his duties included a responsibility for the profitable conducting of the royal domain manors lying within his jurisdiction, and in the first century for due information of occasional opportunities for revenue, like marriages, wardships, and escheats. He was also the local military representative of the government through whom general summons to military service would be sent to all tenants in chief not receiving an individual summons, and especially responsible whenever the general levy-the fyrd-was called into service. In addition to these functions in the ordinary carrying on of government, the sheriff was during the first century one of the chief, though not the only, organ in the localities of the king's prerogative action.

It is very easy to see, even from this outline [74] 
account, that the shrievalty was a primitive, almost a crude, organ through which to carry out locally the general government of a wide territory, and yet it should be evident that, if sufficiently checked and controlled by the central government in the exercise of its vague and elastic functions, it was really a most effective organ in a simple and undifferentiated state. This is what the Norman state was, simple and undifferentiated. The two great and characteristic institutions which almost alone formed its constitution were the curia regis and the shrievalty, through each of which all functions of government were at once exercised, one for the land as a whole, the other for local districts into which the land was divided for more effective supervision. But it was a real government in which the central kept careful hand on the local. Its very simplicity in a primitive time tended strongly to centralization.

The object of this introductory account of the general machinery of the ordinary or normal AngloNorman government has not been to state the facts primarily for information. They are already sufficiently well known. It has been rather for the purpose of distinguishing clearly this side of the government from the occasional institutional action of the king, his prerogative action as it has been called, which is now to be described, in order if possible to exhibit over against one another those two separate and distinct sides of the governmental activity of the 
time, with special reference to the future development. A second object has been to make clear both the simple, undifferentiated character of the government and at the same time its high degree of centralization. All these things are of great importance in their bearing on the changes of the second century, and if they are not clearly perceived at the outset those changes will not be fully understood in all their origins and relationships.

To complete our sketch of the general constitution of the first century we have now to consider those instances of institutional action which occur occasionally and are not produced by the constantly acting everyday machinery of the state but are the result of interposition on the part of the king for special purposes or on special occasions; interferences to procure results which might indeed in some cases have been produced by the regular machinery, but more slowly, or more uncertainly, and in many cases not at all. This prerogative action of the king's may be seen most clearly by an examination of three typical cases; these are also the cases having the most important bearing on the later development of the constitution. They are: first, the writ; second, the special commissioner or justice; and third, the jury.

By specifying the writ as one of the classes of prerogative action $I$ do not intend to assert that it was not also a part of the regular machinery of the state. It was so constantly employed and so essentially 


\section{INSTITUTIONAL INTRODUCTION}

necessary in such a simple and undeveloped government that it is impossible almost to conceive of that constitution in operation without imagining the constant employment of the writ. It was used by the Anglo-Saxon kings, and we may say by every early government in some more or less related form as a constant dependence. The writ we may define in simple terms, for our present purpose, as an order issued by the king, directed to some officer, or to some individual, or to a group of these, commanding that some specific thing be done and often that a report of the performance be returned to him. Those writs which are essential to, or incidental to, the ordinary operations of the governmental machine, like a summons to attend the curia regis, fall out of consideration here. The same process was, however, very frequently employed, when the king wished to secure some result not probable, or not possible to the ordinary machinery, and the writ may be regarded, in form at least, and perhaps in more than form, as a bridge, or connecting link, between the regular action and the prerogative action of the Anglo-Norman government.

Two writs which had taken definite form at the close of the first century (1166), or certainly very soon after the close of that century, and whose roots ran back to an early point in it, may be taken as the most easily understood and clearly typical instances of these prerogative writs. The one is the writ of 


\section{ORIGIN OF THE ENGLISH CONSTITUTION}

right, the other the writ called the Præcipe quod reddat.

The writ of right is not merely typical of this employment of the writ, but also strictly typical of the whole prerogative action of the king. These are the circumstances in which it was issued and this is what it was: In the modern state cases of local judicial need fall to the care of local courts which are an integral part of the general judicial organization of the state as a whole. We find it difficult to conceive of any other arrangement, but it was not so in the feudal state. There a large proportion of such cases were under the control of a court which was a personal and very profitable private possession of the feudal lord and formed no part of any organically connected general judicial machinery of the state as a whole. Every feudal lord, who had a sufficient extent of property, was likely to be in possession of three distinct kinds of jurisdiction, and he might have a distinct court corresponding to each, what we may call the feudal proper, the manorial, and the jurisdiction of a local public court transferred to him, or usurped by him, sav a hundred court - or perhaps in this last class he had merely the right to try in some other court of his a certain range of cases which ought normally to go into such a public court. At this point we are concerned with the first of these only. The lord's feudal court was, like the king's, an assembly court composed of his vassals and having jurisdiction 


\section{INSTITUTIONAL INTRODUCTION}

of the disputes arising among them, or between any of them and him, as to the ownership of feudal property or the definition and enforcement of feudal rights and duties. ${ }^{15}$ Let us take as an example a case of the kind which frequently gave rise to royal interference by writ of right: The knight $\mathrm{A}$ claims the right to hold a certain manor as a vassal of the earl of Oxford. The earl disputes his claim and is in possession of the manor. Normally the case should be tried in the earl's feudal court, by the other vassals of the earl, on its merits without reference to the special interests of the earl who has no voice in making the judgment of the court. ${ }^{16}$ But $\mathbf{A}$ finds it impossible to get it tried; probably the earl does not wish it to come to trial. This is a case of defect, or default of justice-one of frequent occurrence in the feudal age. What is $A$ to do? If he trusts to the earl's justice only, which he is bound to do under the feudal law, his case is lost. But he may appeal to the king. It is the king's business to see that justice is done to all his subjects and though in the feudal system interpreted strictly a case between the earl of Oxford and the earl's vassal is no business of his and he has no right to interfere, except by way of the regular feudal appeals, in the other conception of his office as king he has the right. Therefore $\mathbf{A}$ obtains from him a writ of right-an order that right be done15 See note $A$ at the end of the chapter (p. 90). 16 See note $B$ at the end of the chapter (p. 91). 
addressed to the earl of Oxford commanding him to do justice to $\boldsymbol{A}$, that is, to try the case in his court, and informing him that if he does not do so, some officer, or person, specified by name in the writ, will do it. That is, the king clearly acknowledges the first right of the earl to try the case, if he will, but he asserts for himself another right, to remove the case from the earl's court, if the earl will not try it, and to cause it to be tried in some court of his own, thus breaking entirely the chain of operations as they would occur in the ordinary course of things. ${ }^{17}$

The Præcipe quod reddat was the same in principle as the writ of right, but it was somewhat more simple in character and it was a more direct interference with the private jurisdiction of the feudal baron. It was obtained by the complainant and was addressed to

17 Such a case on removal from the baron's court was usually tried by the sheriff in the county court, but, it should be observed, not as acting in his ordinary capacity as sheriff, but as a special commissioner, or king's justice, under the writ (per breve domini regis, Glanvill, I. 4), and the county court in such a case becomes a king's court, the king's county court. How the king's writ would be treated in a baron's court disposed to obey, is shown in an interesting early case. In 1121 , according to the record, there was brought to the court of the bishop of Bath a writ of William, son of Henry I., reading: Præcipio ut saisias Modbertum juste de terra quam tenuit Grenta de Stoca, sicut hæreditarit eum in vita sua. The writ having been read before the court, the bishop said: Sicuti per has mihi litteras a filio Domini mei mandatum est fieri, si tamen justum est acquiesco. Vos autem, ros amici mei et Domini, qui propter apostolicum diem solenniter huic adestis curiæ, quid in hoc justius sit discutere precor dignemini. The case then went to trial and was finally decided by a committee of the court in favor of the defendant, the bishop's church. Bigelow, Placita, p. 114-117, from Madox, I. 110-112. See chapter III, note 8 . 
the sheriff, ${ }^{18}$ commanding him to require the defendant to return to the plaintiff a specified piece of land of which the plaintiff had complained to the king that he had been unjustly disseised, or if he does not do so to appear before the king, or the king's justice, at a certain time and place, and explain why he has not obeyed the king's order.

It will be seen at once that this writ, unlike the writ of right, ignores entirely the baron's court. It starts out with the assumption that the plaintiff's cause is just and begins with a flat command to the defendant to act upon that view of the case. The king arrogates to himself the right to correct a piece of injustice by a direct order, as if he were commanding an army in the field. Then the writ goes on to admit that the defendant may disobey. He may have a different view from the plaintiff of what is just in the given instance. In that case, however-and here should be noticed the completeness and the skill with which the writ dodges the difficulty created by the lord's right of jurisdiction-he owes an explanation to the king of his act of disobedience. The writ is not a direct summons to the defendant to appear before the king's

18 In early Frankish practice the royal order, the indiculus commonitorius, from which the writ Præcipe descends, was addressed directly to the defendant. See Form. Marculf, I. 29, ed. Zeumer, p. 60; Brunner, Schwurgerichte, pp. 78-80; Rechtsgeschichte, II. 137 (1892). The writ was also sometimes addressed to the defendant in the Anglo-Norman practice. See Bigelow, Procedure, pp. 154-158. On the Anglo-Saxon writ and its relation to the Anglo-Norman, see Mr. W. H. Stevenson in E. H. R., XI. 735 . 
justice for the trial of the case. 'The Anglo-Norman kings never seem to have ventured upon so bald a violation of the lord's rights as that would be. It directs something quite different in form-that the defendant explain his disobedience of the king's order, but when he appears before the justice his explanation naturally consists of a statement of his view of the case, against which the plaintiff naturally urges his, and the case is really on for trial. ${ }^{19}$ The Præcipe quod reddat is really a writ of evocation. It transfers the case bluntly from the baron's into the king's court, without so much as by your leave, but it says nothing about all this. It proceeds upon an entirely different theory-the theory of the non-feudal office of the king to make general justice prevail. Against this action of the king's depriving the baron of his right to have the case tried in his own court, he can offer no objection unless he is ready to take the position that in this range of cases the king must be bound by a strictly feudal interpretation of his office. ${ }^{20}$

It should be easy to see the significance of these writs and their importance as a means of interpreting the constitutional situation of the first century. In both cases the king interferes in the normal operation of things in a way not provided for by the regular machinery of the state-he falls back upon a different ${ }^{19}$ Procedure in the trial of the case actually does not follow this order. The court does not modify its rules to suit the theory of the writ, but the theory is plain enough.

${ }^{20}$ See note $\mathrm{C}$ at the end of the chapter (p. 96). 
conception of his office from that which prevails in the daily conduct of affairs ${ }^{21}$ - to produce results which, in the first instance, might occur but which would not under the circumstances be likely to occur, and in the second case, the direct transfer of a suit to his own court, certainly would not occur, without his interference. These instances are typical of the whole group of cases which are to be called prerogative acts.

The second class of these cases mentioned above is that of the appointment of special commissioners, or king's justices. The king wishes to look with more than ordinary care into certain local interests of his; or to examine on the spot a difficult problem of local administration or local justice; or to obtain specially full or accurate information in regard to a question of any kind. Instead of depending upon the local officer provided by the ordinary machinery of the government for such purposes, the sheriff, he sends special commissioners, charged with this particular duty, and superseding for these questions the authority of the sheriff. The sheriff himself may be made a member of the commission, or he may be made the subject of its examination for the purposes of the commission, or even to determine how faithfully he has performed his duties, and whether complaints which have reached the king against him are well founded or not.

21 See chapter IV., note 24. 


\section{ORIGIN OF THE ENGLISH CONSTITUTION}

An early instance of this action, which is typical of all, is the process by which the great Domesday survey was made in 1086. King William I. wished to ascertain, chiefly for financial reasons, the facts in regard to every feudal holding of land in the kingdom, whose it was and whose it had been before the Conquest, what portion of it was cultivated, what number and what kinds of dependents held portions of it as subtenants, what stock it carried and what special sources of revenue to the lord there were in the way of mills and fishponds, whether it had declined or increased in value since the Conquest, and finally whether it could be made to yield more to the state than it was doing. It was an inquiry so minute that it could be satisfied only by calling upon all the resources of local knowledge, and it was an extraordinary undertaking certainly which never would have been entered upon in the ordinary conduct of the government, for which the ordinary machinery provided no means and to which it would probably have proved itself inadequate. But William, though he put into operation extraordinary machinery to accomplish his object, employed also the local organization to assist it, as much as he could. This combination of extraordinary machinery created by the prerogative action of the king with the existing machinery of the ordinary government is typical from the beginning of the second and third classes of prerogative action. 
To carry out the purpose of the survey, contiguous counties were grouped together into districts, the first instance of this kind of grouping that we know of in English history, and to each of these a set of commissioners was sent, charged with conducting the inquiry. In the district each county was made a separate unit, and in the county inquiries were made and action called for sometimes from the county, sometimes from the hundred and sometimes from the vill. The commissioners, who were called barons, a title which seems to imply that they were authorized to hold in the places where they sat a court having the powers of the curia regis, had the right to put the men of the localities, including the sheriff, upon oath and to require from them definite answers upon the points in regard to which the king wished information. Here again we have a simple process, admirably adapted to secure the desired end, but all lying outside the scope of the regular governmental processes, all created by the special action of the king.

But the foregoing is not quite a full statement of the method of the Domesday survey. An institution was put into operation by the commissioners which we find almost always associated with special royal commissioners as a means by which they accomplish the object for which they have been created, whatever it may be. Instead of putting individuals upon their oath and calling upon them to answer the required questions, they formed in each local unit, 
usually in each hundred, but it might be in the vill, or in the county as a whole, a body of selected men, usually six, or some multiple of six, in number, who were sworn and required as a body to reply of their common knowledge to the questions submitted to them. This is the jury-the juré-the body sworn to answer truly. In the Domesday survey the jury is employed in a way in which it was often used in the early ages of its history, to get information for the king-it may be on any kind of a question-which it is important for him to possess but which he can obtain only from the men of some locality who know the facts. This was probably its earliest use, ${ }^{22}$ and it was certainly from the application of such a use to similar questions in cases before the king's courts that the modern function of the jury in the trial of suits at law was derived. This process of derivation can easily be understood if we return to our example to illustrate the writ of right. The decision of such a question as that supposed to be at issue between $\mathbf{A}$

22 The Carolingian use of the jury is admirably summarized in Brunner, Rechtsgeschichte, II. 524-526 (1892), and his account may be taken as almost as exact for the Anglo-Norman jury before the enlargement of its use begins, although Brunner gives no evidence of having anything but the Carolingian jury in mind in writing. A comparison of his account with the instances of the jury process in England before the new writs begin is sufficient to show in one case how closely Carolingian English prerogative action was. The developed use of the jury in the twelfth century was also entirely logical, and together with that of the writ, which is closely bound up with it, serves to broaden and fortify the royal prerogative action as inherited from the Carolingian empire, admitting that to be the source from which it was derived. 


\section{INSTITUTIONAL INTRODUCTION}

and the earl of Oxford may turn upon who it was that held the manor in dispute during the previous generation. Was it a man whose heir A clearly is, or was it some one wholly unconnected with him, whose death without legal heirs leaves his manor as an escheat in the hands of the earl, or did whoever it was hold it by a temporary title and not in heredity? The king's court, the court of a king's commissioner or justice, to which the case has come under the writ, finds it necessary to get trustworthy information on these points, and in order to do so it makes use of the king's prerogative, summons men from the locality who are supposed to know the facts, as the royal commissioner was often accustomed to do in other matters, and requires them under oath to inform the court about the last holder of this manor and his connection with the plaintiff or the land. Thus is begun the use of the jury in the trial of cases in the courts.

This whole series of cases was, however, during the first century all outside the ordinary action of courts and constitution, even outside the normal and ordinary action of the curia regis itself. The writ of right, the special commissioner, the jury, was the king's only. No one could get his special case, his suit at law, his complaint of injustice, before a royal justice, or have the use of a jury to prove the facts which were essential to his case, unless he got the king's permission in advance, a permission which was involved in the writ which he obtained commanding 
his opponent to do him right. These were special royal processes and they formed no part of the ordinary machinery of government from which baron or common freeman must seek justice if he did not choose to invoke the king's special intervention.

The first century, however, was not a stationary age. There was in the course of it a good deal of development in the use of these processes, so much indeed that when Henry II. carried them on into the great age of their history scarcely anything seemed to be added to what was already at least occasionally in practice. Under William I. the instances of their use, which are not few, are wholly individual, unconnected and sporadic. We find no hint of any systematic employment of them, or of any tendency on the part of the king to believe that a development of them might add greatly to the strength and efficiency of his government. Under Henry I. the instances of their use multiply rapidly, or at least the evidence of their use which has come down to us. This is particularly true of the writs, of which we have large numbers from his reign, but more interesting still are the indications which we get of the frequent employment of special king's justices. These processes are indeed so constant and characteristic features of the documentary material of the reign that when we take a comprehensive view of it we find ourselves almost inevitably tending to believe in their more regular and systematic use than we can prove specifically to have 


\section{INSTITUTIONAL INTRODUCTION}

been the case. It is altogether probable, however, that the documents as we have them fairly represent the actual stage of development reached at the time, with the barely possible exception of a more regular employment of the special justice in the capacity of the later itinerant justice. We may at least believe in the unusual political ability of Henry I., and in the clearness with which he saw the value of these institutions to the central government and that he showed the way to the greater results which were possible for his grandson. If so the anarchy of Stephen's reign might be made not inadequately to account for the breaking to pieces of a system not yet firmly established by time, but it is true, as I have already said, that when we get our first evidence of the later regularized and systematized use of these practices, their aspect is not so much that of the fragments of an older system as of new beginnings. These beginnings were made, so far as we now know, ${ }^{23}$ in Normandy and not on English soil, under a government at the moment not connected with England, and they open a new age-the first great age of growth in the history of the English Constitution.

${ }^{23}$ See the article of Professor Haskins on the early Norman jury, A. H. R., VIII. 613-640, and below chapter III., note 2 . 


\section{ORIGIN OF THE ENGLISH CONSTITUTION}

Note A. Private Jurisdiction and the Judicial Position of the Common Freeman

(Page 79.)

THE statement of the jurisdiction of the feudal court made in the text is that of the feudal court strictly interpreted, and as such it is true of all countries where feudalism existed. But probably in all countries, certainly in most, this court was made to serve other purposes also, and in respect to these additional functions there is no general agreement. See the discussion of this subject in Flach, Origines de L'Ancienne France, vol. I., Book II., especially chapters VIII. and IX. He emphasizes: La distinction entre la cour des pairs siégeant comme vassaux et la cour des pairs siégeant comme fidèles [subjects]-distinction qu'il ne faut jamais perdre de vue, sous peine de ne rien comprendre au fonctionnement de la justice pendant les $\mathrm{X}^{\mathrm{e}}$ et $\mathrm{XI}^{\mathrm{e}}$ siècles ni à son sort ultérieur. In England the common freehold within a manor might fall under the care of a court which should have been strictly feudal, and such a court might also serve as a kind of supervising court, or court of higher jurisdiction, for the separate manorial courts which were included in the barony or honour. See the cases coming before the court of the honour of Broughton, Maitland, Manorial Courts, Selden Society, vol. II. It is the existence of the common freehold which is neither feudal nor servile, and of the common freeman who is neither serf nor vassal, which renders the subject of private and local jurisdictions in England peculiarly complicated, in addition of course to the fact that private jurisdictions in England never obtained full liberty of development.

On this situation, and the reasons for it, I may repeat from the American Historical Review, vol. VII. p. 18: It seems more than probable that the personal freedom of the holder, not the character of the holding, is what accounts originally for the features common to these tenures and the feudal proper. If 
tenure only had been in question the result would probably have been the same, in regard to judicial position, as that in France. The man is personally free and a part of the same political organization with the holder of the manor. His small farm has been drawn into the manorial organization by his economic dependence, or by his need of protection in turbulent times, or he has himself taken a holding formed in the manor, but in either case on a footing different from those who hold servile tenures in the manor. He thus stands from the start in a double relationship. The causes which have created his holding draw him into the manorial organization, and bring him into a relationship far closer to the class below him than to the class above. As an individual, however, in relation to public affairs, he is classed and acts, so far as he acts at all, with the higher class, though he stands certainly in the background, and is apparently always a second choice. As these public relations become feudalized, the judicial for example, he belongs on one side to the feudal system. As the feudal interpretation becomes the prevailing one, the temptation is especially strong to apply it to the customary freehold, which is certainly not servile and whose holder acts in many capacities with the knight. It becomes easy to attach feudal incidents like homage to such holdings. The confusion in this borderland is greater in England than on the continent partly because the local political organization retains there through all the feudal age so much more importance, and partly because when the national judicial system arises, royal and anti-feudal, it finds no reason for recognizing a distinction between these classes which the local system had not recognized and every reason for not doing so. It is an important fact, however, that while the thirteenth century tends to carry over into the class of common freeholds some holdings that would earlier have been called feudal, it does not show the least tendency to obliterate the essential legal distinctions between the two classes of tenures. Littleton shows that this drift out of the strictly feudal class went afterwards somewhat further, but the distinction is still perfectly clear, and remains so as long as feudal tenures proper exist in 


\section{ORIGIN OF THE ENGLISH CONSTITUTION}

England. Legally the payment of scutage and the character of wardship were distinguishing marks.

This double position of the common freemen indicates a complicated enough judicial relationship. Within the manor they were members of the lord's manorial court for manorial customs and questions, "and there the serfs were their peers; but they were also members of the old national courts of hundred and shire, and there they were the peers of knights and barons" (Polit. Hist. Engl., II. 16; cf. E. H. R., XXI. 566-567), acting constantly with the knights and the representatives of the barons in the king's county courts both on accusing and civil juries and in the assessment of taxes. See Stubbs, S. C., pp. 143, 148, 257, 259, 367. For the twelfth and thirteenth centuries, it would be of course a very narrow application of the word "peer" to make it refer to trials only, but I am not aware that the presence of the common freeman on the jury in the national courts was ever objected to, though that of servile holders was. See Pipe Roll Soc., XIV, 38 (also in Hall, Form. Legal Records, p. 207); Madox, I. 546, $s$ and $t$. The case of a baron came rarely before any county court, even the king's, for final trial in an important matter, and when it did undoubtedly the presence of the common freeholder on the jury might be protested (cf. Très. Anc. Cout., c. XXVI.), but in recognitions in civil cases in the itinerant justice court it seems not to have been, and the presenting juries not infrequently call attention to the cases of men of baronial rank and upon the returns made by such juries the court may act. See Maitland, Select Pleas of the Crown, Selden Soc., I. cases 44, 50; Maitland, Pleas of the County of Gloucester, cases 154, 209, 308.

The passage, a part of which is cited above from the Political History of England, manifestly did not refer to the lord's feudal court proper, but there the situation was the same, as may be seen in the records of the court of the honour of Broughton cited above. Sec pp. 61, 76. The baronial members of that court were constantly being distrained by judgment of the court. See p. 62. Still more important, the rendering of military service was 


\section{INSTITUTIONAL INTRODUCTION}

apportioned by common freemen. See p. 76. That is, such a strictly feudal matter is the business of the court, not of the feudal tenants merely. When the feudal court proper disappears, as it seems to be doing rapidly in the second half of the thirteenth century, and courts of manors come to act more generally than they had before as courts baron, it seems altogether probable that the baronial element proper drops out of these courts entirely and the common freemen with the holders of small military tenures, who were practically almost in the same position with them, become the constituent and operative members of the court. This should be the great age of the origin of courts baron, but it seems to me that we can hardly explain all the facts regarding private jurisdictions in England without supposing that such courts had existed in fact if not in name in many cases from the Norman Conquest. In the operation of the court baron the freeman might possibly be brought into relations with unfree tenants which would be even more decidedly opposed in theory at least to feudal ideas of "peerage" than in the manorial courts. In the operation of the manorial courts proper the action together of common freemen and serfs as peers of the court hardly needs illustration. Such cartularies as those of Ramsey and Gloucester are full of instances, in the extent juries for example. For the use of the word "peer" in such a connexion see Ramsey, I. 54. On this and related questions see Maitland, Manorial Courts, Selden Soc., II. pp. lxviii.lxxiii., a passage which shows admirably the difficulty of the subject in its widest form, but it is to be noted here again that the word "peer" in the phrase judicium parium is used in a special and restricted sense. On the French roturier, in comparison with the English common freeman, see Esmein, Histoire du Droit Français (1898), pp. 241-242, and on his judicial position especially, pp. 222, 255-256.

The mixed jurisdiction of any particular private court, the confusion of the three types of jurisdiction in such courts, in England should not lead us into the error of supposing that any sharp distinction between the three is arbitrary and theoretical. They remain distinguishable so long as feudalism retained any 


\section{ORIGIN OF THE ENGLISH CONSTITUTION}

significance, and the ability to distinguish between them is of great assistance in understanding many puzzling facts. The causes already indicated, the strong Norman centralization and the position of the common freeman, tended in one direction to make feudal jurisdiction proper of little importance and without political significance, and in another to confine public jurisdiction in private hands to affairs of minor importance. It is probable that even from the beginning all private jurisdiction was chiefly of economic interest to the lord. But such a condition of things does not in the least tend to show that these distinctions did not exist. The German systems of Dienstrecht, developed for a class which was really a vassal class, and passed ultimately into the nobility, but which was not allowed any standing in feudal law proper because it was technically servile, show how sharply the distinction was sometimes drawn on the continent.

\section{Note B. The Lord's Cases in His Own Court}

\section{(Page 79.)}

THE question whether the lord could be sued in his own court is one of considerable difficulty. The History of English Law is of the opinion that he could not be: "On the other hand the lord cannot be sued in his own court; this is as true of him as it is of the king. The proper feudal course for one who claims to hold land of $\mathrm{X}$ but cannot get that land is to demand justice from $\mathrm{X}$, and if this demand fails to go to the court of X's lord. A lord distrained to answer in his own court is the most startling anomaly of the ancient demesne." P. and M., I. 589.

I am not prepared to say that, tested by the technical forms of procedure in any given case, this statement is not correct. I think it is at least questionable, and evidence as to technical procedure in the baronial courts seems to me too scanty for definite assertion. But however it may be as to the technical forms into which cases were thrown, there can be no question but that the evidence indicates the trial of cases in the lord's court in which 


\section{INSTITUTIONAL INTRODUCTION}

the lord was, on the merits of the case, the defendant, for example, in the cases referred to in the following writs. Henricus, rex Angliæ, Henrico comiti de Warewic et Willielmo vicecomiti, salutem. Si Goscelinus quid clamaverit in terra Santæ Mariæ de Abbendona, quam habet apud Hyllam, præcipio ut ipse Goscelinus eat in curiam abbatis, et ipse abbas sit ibi ei ad rectum; et defendo ipsi abbati, quod non respondeat inde Goscelino in alio loco. Chronicon de Abingdon, II. 93. Stephanus, rex Angliæ, R. parvo, salutem. Si cognoscis quod debeas tenere virgatam terræ quam tenes in Quedesleya de abbate Glocestriæ, tunc præcipio tibi quod, desicut abbas dicit quod rectum in ea non habes, aut eas in curiam ejus dirationare quod tua esse debeat, vel dimitte ei terram suam. sicut justum fuerit. Et nisi feceris M[ilo] Gloucestriæ faciat, Cart. Glouc., II. 96. In both these cases the writs were undoubtedly solicited in the abbot's interest, to secure the trial of the case in a court presumably favorable to him, but in both the suit is clearly against the abbot. That is, he is virtually the defendant. Cases with a similar presumption may be found in the Ramsey Cartulary, I. 233, No. 145; 237, No. 157; 245, No. 169. In the Latin translation of the Leis Willelme (1090-1135; translation made about 1200 ), c. 23 reads: Si voluerit quis conventionem terre tenende adversus dominum suum disracionare, per pares suos de eodem tenemento, quos in testimonium vocaverit, disrationabit, quia per extraneos id facere non poterit. Liebermann, Gesetze, I. 511 (ed. Matzke, p. 20). Cf. Libri Feudorem, II. 16. The reference to the lex Conradi in the passage in the Libri Feudorum is to the constitution of 1037 , second paragraph, Mon. Ger. Hist. Legum Sectio, IV. T. I. 90, clearly implying the decision of cases against the lord in his own court. There can be, I think, little doubt about the matter on the continent. See Luchaire, Manuel Inst. Franç., p. 203; Glasson, Hist. Droit de la France, IV. 363. In Normandy in 1198 it is recorded that Thomas de Brikevilla reddit compotum de 70 solidis pro 10 besanciis pro habenda recognitione de finibus factis in curia Fulconis Paganelli versus eundem Fulconem. Stapleton, Magni Rot. Scacc. Norm., II. 297; Thomas was a vassal of Fulk's, cf. 


\section{ORIGIN OF THE ENGLISH CONSTITUTION}

Ibid., p. x. See a suit against a right claimed for the lord in Round, Calendar, p. 81, No. 232.

To "demand justice" of the lord was not to demand that the lord at once accept the plaintiff's view of his case and act accordingly. It was to demand a trial of the case in the lord's court, and default of justice was most often committed by refusing a trial, by denying the court to the vassal (vetare curiam). A lack of evidence of suits against the lord in his own court in the thirteenth century, after the operation of the king's courts becomes extensively developed, is not to be taken as proof of the state of things in the eleventh and twelfth centuries, and in general this is one of the points on which evidence from the second half of the thirteenth century must be used with caution. It will be noticed that the bringing of a criminal appeal against the lord has not been considered in this note, nor cases in which the lord is a plaintiff in his own court, and distraint of the lord is also a different matter. On this last see Ass. de Jer., Jean d'Ibelin, cc. 243-244. On a case of the king's, though not necessarily as defendant, see the interesting stipulation by the abbot of Abingdon of a right to his vassal's counsel in the curia regis, nisi contra regem placitandum forte fuerit, Chron. Ab., II. 133.

\section{Note C. On Glanvill, XII. 25}

$$
\text { (Page.82.) }
$$

ON the Carolingian prototypes of the writs of right and the Præcipe writs, from which they probably descended, and on the fundamental right of the sovereign on which they were based, the same as that underlying the system of equity, see Brunner, Schwurgerichte, pp. 73-83, 407-413; Rechtsgeschichte, II. 137; Flach, Origines, III. 366, 372-373. On the question of the lack of documentary evidence to prove the intervening line of connection, in the case of the somewhat wider appeal of default of right in general, see Viollet, Institutions Politiques de la France, II. 213-214, words which apply equally well to the problem of 


\section{INSTITUTIONAL INTRODUCTION}

the connection of any feature of the Anglo-Norman constitution with the Carolingian, and see Brunner, Schwurgerichte, pp. 60$62 ; 127-131$.

The immediate institutional basis of these writs in the AngloNorman practice since the Conquest seems quite clear. In addition to Brunner's Schwurgerichte, see in more detail Bigelow, Procedure. The ethical basis, the fundamental right upon which the king rests his action, seems equally clear. When we pass on, however, to another principle which is stated in Glanvill in unmistakable terms, we are confronted by a serious difficulty. Glanvill, XII. 25 reads: Præterea sciendum, quod secundum consuetudines regni nemo tenetur respondere in curia domini sui de aliquo libero tenemento suo, sine precepto domini regis vel ejus capitalis justicie. There is stated in these brief words the most extraordinary and the most sweeping of all the regulations by which Henry II. attacked the feudal system. If it is established as a recognized principle of the law, the whole foundation of legality on which rested baronial jurisdiction proper is destroyed at a single blow. The baron's court of vassals has henceforth no logical existence; it goes on only by sufferance of the king. If the baron can no longer of himself distrain his vassal to perform one of the primary duties of the feudal relationship, to answer in his court to a suit begun against him, his ability to maintain his jurisdiction against any kind of an attack is at an end, and the foundation of feudal duty upon which it rests is destroyed. I do not of course intend to be understood as asserting that feudal jurisdiction as a practical fact was actually brought to an end by this principle, but only that its destruction was logically involved. The Petition of the Barons, c. 29 (1258, Stubbs, S. C., p. 386), shows one method by which an attempt had been made to protect feudal jurisdiction against the operation of the writ of right-a method wholly in accordance with feudal law, and developed possibly through encouragement given by Magna Carta, c. 34, though this clause refers to the writ Præcipe, and not to the writ of right. See Glanvill, XII. 7, 2. Perhaps some similar method had been discovered for this other case. 


\section{ORIGIN OF THE ENGLISH CONSTITUTION}

So surprising is the dictum of Glanvill that one is tempted to deny the evidence of his senses. The proof that it existed as a part of the actual law is not large in amount but it seems indisputable. The statement in Glanvill is perfectly definite. It cannot be mistaken. So far as I know it is the only evidence for the twelfth century. That the principle was secundum consuetudines regni as the passage in Glanvill says has never been shown. According to Brunner, Schwurgerichte, p. 410, and Maitland, Manorial Courts, p. liv., it was not recognized in Normandy. In 1207 John extended the principle by letters patent to Ireland. Rot. Pat., p. 76. Bracton, f. 106, states it as clearly as Glanvill, but gives no evidence of its enforcement in the courts. The Provisions of Westminster, c. 18 (Stubbs, S. C., p. 404), demanded that it should be regarded. I know of no other evidence of its existence down to the end of Henry III.'s reign. But this surely ought to be enough. It certainly creates a presumption which it would not be easy to overthrow. When, however, we raise the questions how such a principle came into existence and on what foundation of right it could be rested, we are at a loss for any answer. Nothing on the feudal side of things can be made to explain it. It runs directly counter to all feudal ideas. If the Anglo-Norman king had been considered the fountain of justice in so nearly an ideal way that no baronial court was regarded as having authority to try an important case, not even a case between two peers of the court and concerning solely a freehold claimed by both to be held of the lord of the court, without a special authorization for the given case, or if it were a principle of the Anglo-Norman feudal law that the rear vassal was so bound to the king that he looked to him alone as the protector of his holding, then Glanvill's dictum would need no explanation, but of neither of these things is there any evidence. Brunner, Schwurgerichte, p. 411 , supposes that this principle had its origin in an ordinance of Henry II.'s, because "innovations of the sort do not usually form themselves in the manner of customary law," and this explanation has the weighty support of Maitland, Manorial Courts, p. liv., Equity, p. 315. Authority so imposing is to be 


\section{INSTITUTIONAL INTRODUCTION}

questioned with hesitation, and certainly one must admit that a matter so fundamental as responsibility for court service could be changed by the growth of new custom only very slowly. But to me at least it seems that the difficulties in the way of supposing that this principle was made law by an assize, as it would be called in the twelfth century, are very great. It is hardly to be believed that such an assize could have been made, and all evidence of it have disappeared. We are dealing with quite a different matter from the possessory assizes or the grand assize. These might easily be disguised as favours. The broad application of the writ of right is of gradual growth, and its ultimate significance might easily escape the baron because of its close connection with the recognized feudal appeal of default of justice. See Très. Anc. Cout., c. XXX. But a piece of legislation, an assize or a "constitution," enacting so subversive a principle as this as an addition to existing law, attacking a widely recognized political and property right of all barons, especially if stated so bluntly as it is in Glanvill, could hardly have escaped attention or have been misunderstood. In reference to the changes of Henry II. in general, it is remarked in P. and M., I. 137, that "a few ordinances or assizes, those which seemed most important to his contemporaries, found their way into texts of Chroniclers." If this statement in Glanvill means what it seems to say, and was given any effect in action, it is difficult to believe that any innoration of the king's could have seemed more important to his contemporaries. It seems far more likely that it would have occasioned a general outcry and awakened bitter opposition.

If such an innovation was made, we ought also, I feel sure, to be able to find some basis of plausible right for it in existing precedents. This at least is what we can do for all other of Henry's attacks on feudalism. Those who were active in developing these processes at that day may not have reasoned very much about what they were doing, nor have thought greatly about theoretical rights, but what they did was to develop the new by gradual steps out of the old. They had in the facts of the immediate past some basis of practical justification for their 


\section{ORIGIN OF THE ENGLISH CONSTITUTION}

changes, and in current ideas some ethical defense, and these are usually not difficult for us to find. They made no sudden or violent innovations, nor left wide gaps in the line of their advance. The possessory assizes and the grand assize were doubtless legislative acts as their name "assize" implies, but in their case it seems quite certain that the legislative act was only the last step in a gradual progress of instances, grown customary, by which the way had been prepared for opening these royal processes to the general public. I am quite aware that in saying this I seem to be implying that the principle of Glanvill, XII. 25, if actually a part of the law, was formed in the manner of the customary law. But it appears to me impossible to account for it in any other way.

I am indeed prepared to go further. The statement as it stands in Glanvill looks to me less like a part of the customary law itself, or an assize, than like the obiter dictum of a judge, or better of a writer on the law, as Glanrill was, who is generalizing from the observed fact that the various writs of right of which he is discoursing covered so large a proportion of all cases about freeholds. In XII. c. 3 and c. 5, for instance, the writer must have intended to include all like instances and he must have understood how wide the application of these writs would be in actual cases. The suggestion that in laying down this principle the writer was thinking chiefly of the writ of right and of what is contained in Book XII. is supported to some extent by the assertion of the same rule in c. 2 at the beginning of the book. There is nothing, however, in the book itself, nor in the writ of right, to warrant so sweeping a generalization. It should not be overlooked that while the writ of right is in the interest of the plaintiff the principle of Glanvill, XII. 25, is in its application in the interest of the defendant, nor does it seem possible that the writer of the Tractatus can have believed, if he carefully considered the matter, that he had included under the cases specified for the writ of right, all cases affecting freeholds and falling normally in the lord's court. Nearly all the numerous cases in which the lord is a plaintiff in his own court are passed over without refer- 


\section{INSTITUTIONAL INTRODUCTION}

ence. The writ of right, not in quite every case but nearly always, goes on the supposition that directly or indirectly it is addressed to the lord requiring him to do something for the benefit of his vassal. We have a writ, for instance, to prevent the lord from demanding indebita servitia, but where is the writ to enable him to obtain debita servitia withheld? This was, however, a case of frequent occurrence, which might in the end lead to forfeiture of the holding and so falling directly under XII. 25. The very interesting charter of Walter de Bolbec to Walter, abbot of Ramsey, which must be dated before the death of Henry I., Cart. Rams., I. 153-155, and cf. pp. 156, 157, clearly states the right of the lord to bring suit against his vassal in his own court, and to distrain him if he refuses to stand to right, with clear intimation that no application to the king is thought of as necessary. Et si forisfeceret abbas aliquid erga dominum Walterum, unde velit eum implacitare, in curia sua veniet, et faciet ei rectum sicut de laico feodo. ..... Et si non venerit abbas, constringat eum Walterus de Bolebech vel heres per pecuniam suam, sicut de laico feuodo. Glanvill, IX. 9 is the nearest example of such a writ, to be obtained from the king, included in the book, but its title plainly implies that it is intended for the case where the lord is unable to distrain his man to stand to right, which is again as plainly implied in IX. 12. Book IX. 8, which is the introduction to c. 9 , indeed distinctly recognizes the right of the lord to bring such suits in his own court without the king's writ, though in theory they involve as final penalty the loss of the freehold, for while, as a result of the general tendency towards increasing the vassal's rights, actual practice in England, as in other feudal countries, had ceased to inflict this penalty, the change had taken place in practice and not in formal law and the theory remained the same. See Établ. de S. Louis, I. c. LXXII., ed. Viollet, II. 115. The writ which follows in IX. 9 just referred to, is one to which, if we leave one side the form of the suzerain's interference, the strictest feudal law can offer no objection, for which indeed it calls as the normal recourse of the mesne lord. The case would have been treated essentially the same way anywhere

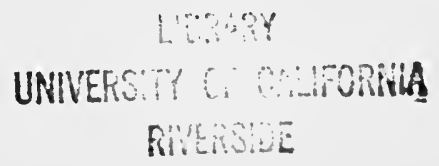




\section{ORIGIN OF THE ENGLISH CONSTITUTION}

in feudal Europe, and the writs cited in Bigelow, Procedure, pp. 160-163, are to be similarly explained. If instead of an ordinary feudal transaction, there had been here an instance of the prerogative procedure of the king, the matter would have occupied a much larger place in Glanvill and have been preceded by a different explanation. The same is to be said of IX. 12. Neither of these writs contains in the slightest degree any such interference with the baron's jurisdiction as that involved in XII. 25.

Nor does the writ of right itself imply in any sense that it is the only way in which a case can be brought before the court of the lord. It rather goes on the supposition that normally the case would have been tried there without it, that it is a failure in the lord's obvious duty to try the case which has led to the writ and that probably after the order of the king has been made known to him he will still refuse to try it and it will, therefore, go to the king's commissioner. This was the only ground indeed, the ground of the refusal of the lord to try a case which he ought to try, known to the feudal law on which a case belonging in the court of a vassal could be transferred to the court of his suzerain, though it is not exactly the foundation of the writ of right. The appeal of false judgment concerned a completed trial, and the writ Præcipe rested on a principle not included in the feudal law in any form.

The doubt expressed in Glanvill, IX. 1, 8, 9, is a very natural one to a writer who asserts the principle of XII. 25, but in my opinion the whole tenor of IX. 1 (the lord in questions of this sort between himself and his tenant has recourse to the king's court only when his tenant is too strong to be distrained by his own unaided efforts) is a much more accurate statement of the law in actual operation at that date than is XII. 25. This riglit of the lord to distrain his tenant to answer in his own court concerning his service withheld is de jure, as the passage says, whatever the writer may think in theory ought to be the case.

If this principle was originally the writer's own generalization from observed facts, once it had been stated in the book, as it is, so as to seem an integral part of the law, it might very easily 


\section{INSTITUTIONAL INTRODUCTION}

come to be regarded as established by those interested in the development of the royal judicial system, and obtain such official recognition as in John's writ to Ireland in 1207. Clause 18 of The Provisions of Westminster referred to above, seems to imply that the principle had not been observed in practice and to demand that it be made statute law. I do not advance this suggestion as a satisfactory explanation of the difficulty. It is to be regarded rather as a confession that I do not know what else to do with it.

The difficulty which is created by XII. 25 is discussed to some extent by Professor Maitland in his lectures on the Forms of Actions included in the volume entitled Equity (1909), pp. 315318. He suggests that the king may have been "able to represent the great step that he took" as "a mere protection of possession." But it is hard to see where there is anything which indicates such a limitation either in the statement of the principle or in the writs which are given in Book XII. The writs would seem to show that they at least may be applied for in any question of permanent rights or status. That the principle may in the end have seemed to rest upon a general royal right to protect possession is very likely true, but the difficulty is to find some idea current in Glanvill's time, or in the generation before his, upon which it can be based, to save it from being a bald usurpation of brute force. I hardly think the king can have been regarded in the twelfth century as having any exclusive right to protect possession. That was one of the primary duties of every lord in the feudal hierarchy, and what destroyed this idea in England was the result of the changes we are considering. They account for this further change, not it for them. The same may be said in effect of what Maitland says in the passage referred to of the in capite clause in the Præcipe quod reddat. The clause may have been used to effect a transfer of the case in a later age, but hardly in the time of origins in the twelfth century, and I think Maitland intends to imply no more than this. In the feudal law a claim to hold of the king in chief would enable the plaintiff to begin suit in the king's court, if he chose to do so, and a Præcipe writ would then be in place, but the court of the mesne lord was equally compe- 


\section{ORIGIN OF THE ENGLISH CONSTITUTION}

tent to try a case in which was raised a claim to hold of the king in capite, and there was nothing about such a claim on which could be based the general use of the writ described in Glanvill, nor any specific writ there given. Glanvill, XII. 5 is very much to the point. It should be noticed also that if this had been all that was involved in the suit, c. 34 of Magna Carta could not have taken the form which was given it. Indeed it is, I think, quite possible that the in capite clause came into general use in the writ in consequence of the prohibition in Magna Carta in order to give a basis in the feudal law for the transfer of a case into the king's court. See McKechnie, p. 410. The following class of cases should also be left out of consideration here. It would have been possible, of course, for the king at any time to bring suit against an alleged immediate vassal to enforce service, to which the defendant could plead that he held not of the king but of some mesne lord, and this would bring the facts of the holding into court, but this was not what was desired in getting the writ, and would be a different sort of case. The case recorded in the Gesta, I. 133-134, is also exceptional, involving a different principle still and probably is not fully stated in the text. It may be said, again, with much probability, that in "the aboriginal weakness and rapid degeneration of the feudal tribunals and the dominance of a royal court which does not love seignorial justice" ( $P$. and M., I. 354) we have the real underlying reason why all these royal usurpations, opposed to feudal law, could be carried through in England with so little appearance of resistance. But this fact could not be assumed by the crown as the justification of its action, and justification of some kind, some show of abstract right, we can make out in every case, I think, except this of Glanvill, XII. 25. It must be remembered also that in some part at least the rapid degeneration of the feudal tribunals and the dominance of a royal court were results of the principles and practices we are considering in this chapter.

It may be interesting to add that shortly before Glanvill, XII. 25 was written the same result was accomplished by another method in the Kingdom of Jerusalem. In 1162 by the Assise 


\section{INSTITUTIONAL INTRODUCTION}

sur la Ligèce, under King Amalric I., the rear vassals of the kingdom were made directly liege men of the king and peers of his court, so that they were able to appeal to its protection as directly as the tenants-in-chief. While this may be said to be carrying further the Norman principle of reservation of allegiance to the duke, or king, in the rear vassal's oath to his immediate lord, it is carrying it a long distance further, to a point never involved or contemplated in the Norman practice. The result would be as squarely opposed to feudal principles as is Glanvill, XII. 25, but since it was clearly accomplished by a legislative act, no question of the right on which it rested need be raised. It would be also unnecessary in the case of the dictum in Glanvill, if there were evidence that it was an assize. On the assize of King Amalric and the method of its adoption, see Ass. de Jer., ed. Beugnot I. 214, Livre de Jean d'Ibelin, c. 140; 319, c. $199 ; 595$, La Clef des Assises, c. 214. This last offers us a delightful glimpse of the feudal mind in its aussi coume les propres homes de celle court said of the right in the high court of those admitted by the assize. An interesting statement of the composition of the court which adopted this assize is made in c. 140 cited above: et fu par la cort dou dit rei et dou dit Girart et de toz les barons et les haus homes dou reiaume et de toz ciaus qui avoient homes qui tenoient fiés d'iaus el dit roiaume et fu celle assise ensi faite et establie. 


\section{CHAPTER III}

\section{The Finst Age of Change}

The reign of Henry II. is the first great age of constitutional advance in the history of England. Whether we regard this advance as the easy and almost unavoidable final step of an earlier progress, the culmination of a century of slow development, or the decisive and creative action of a political genius, our judgment of it is the same. ${ }^{1}$ However clearly the way may have been pointed out by Henry's grandfather in England, or by his father in Normandy, it is in his time that these changes are finally

1 The former of the two suppositions seems to me the more probable. There is too little evidence to allow any opinion to be strongly held, but I have seen no reason to modify the inclination expressed in The Political History of England, II. $255-258$, to rank the grandfather higher than the grandson. Henry II.'s political policy in France seems to me so clearly lacking in insight and foresight, so wanting perhaps it would be more accurate to say in the signs of unusual genius, that I find it hard to regard him as a constructive genius in constitutional matters. But he must have known how to encourage and sustain the best of his civil servants; he saw the needs of his time and was earnest to improve the administrative machinery; he believed in what his grandfather had done and desired to follow his ways. He must have been quick to see the good points of any new plan proposed and to take advantage of useful suggestions whenever he found them. Such qualities make a great king, if not exactly a creative genius.

2 See Haskins, A. H. R., VIII. 618, 625-628. Professor Brunner still maintains (in his Geschichte der Englischen Rechtsquellen, p. 65, note 1, 1909) his earlier view expressed in his Schwurgerichte, pp. 301-301, that the writs which contain the evidence of these innovations in Normandy are from the earlier years of Henry II. rather than from Geoffrey's 
made and the new methods become permanently a part of the constitution. As compared with any earlier stage of English history, his is an age of rapid and almost revolutionary advance. The first century of Anglo-Norman history seems to us as we now look back on it one of comparatively little change. Processes which were in use from the beginning came into more frequent employment. We begin to be able to distinguish classes in actions that are closely related, whether the men of the time recognized the distinctions as we do or not. There was some growing precision of feudal law and some increase in the practical power of the sovereign. But all these changes were gradual, by imperceptible steps; there is no portion of the century of which we can say with certainty that its special characteristic is a series of deliberate innovations, or what seem to be such, which introduce an age of new institutional forms and processes permanently influencing the constitution. It is this that we can say of the reign of Henry II.

The changes which give to the age its distinctive character concern the general organization and the auxiliary institutions of our judicial system and it is in this respect that they are most often considered. This is, to be sure, the result which abides in the con-

time, but Professor Haskins's study of the content of these writs seems convincing, and if his judgment is also correct (and it appears to have had satisfactory confirmation), that a capital " $G$ " as a guide to the rubricator may still be traced in the margin of the cartulary, it does not seem possible to avoid his conclusion. 
stitution of today, but in the study of the hundred years of active change from 1166 to 1266 to regard these changes chiefly as the origin of the judicial system, is to lose the significance of the earliest phase of this century, and to a considerable extent the constitutional meaning of the whole age. Students of the period do not indeed overlook the contribution which these judicial institutions made in the course of time to the practical operation of our system of civil liberty, especially in the jury and in the principles of the common law. Nor is their influence in strengthening the absolutism of the Anglo-Norman kings and drawing tighter their centralization entirely disregarded. It is, however, the results which followed from them in this direction that I wish particularly to emphasize, for however important they may have proved themselves as special institutions in securing the liberty of the citizen as against the executive, far more important was their influence in leading to the limited monarchy, if only by way of reaction. This may be asserted with emphasis because the limited monarchy is the really essential feature of the English Constitution, that which made all else possible, without which neither the jury, nor the principles which came into the common law, nor any other of the special features of constitutional liberty would have been of any avail.

From this point of view what occurred in the reign of Henry II. is to be considered under two heads: 
First, the institutional changes themselves, the fitting of new institutions into the judicial organization of the state, and second, the more general constitutional results which followed from these changes. First, the changes in the judicial organization consisted in the establishment of a permanent system of itinerant or circuit justices, in the beginning of a distinct common law court, and in the opening of the king's writ and the jury to general use in both criminal and civil cases. In regard to these institutional changes, it is to be carefully noted that the particular thing which is done is not new, unless it is possibly in the use of the jury in criminal justice, and in this case the most that can be asserted is a new application of a familiar process. In all cases what is new is form rather than principle. The innovation which is of real importance consists in transferring these things from occasional prerogative use to a regular and permanent place in the ordinary machinery of the state. It should also be noticed that we have in most of these cases clearly evident or clearly implied an act of legislation by which the process concerned was made regular, indicating some degree of deliberate action.

To attempt to describe the second, or constitutional results of these changes in a single sentence, or even in a paragraph, is a doubtful experiment. But we may at least go so far as to say that the great result of Henry's reign in making the occasional, extraordinary, prerogative action of the king a part of the 
everyday machinery of the state, open at all times to all freemen under the proper conditions, was to afford to all a recourse against the practical results of feudalism, constituting the king more directly the protector of the rights of all individuals than the tradition feudal constitution allowed, and greatly enlarging the field of the king's activity, both in extent and in content. This was, in some of the most important functions of government, to create an organized institutional foundation for absolutism which had not existed in the feudal constitution.

One who studies the changes of the time from this point of view must start from the fact that they were all based upon, were all outgrowths of, the prerogative action of the king. They did not start from any part of the regular machinery by which the business of government had been carried on during the previous one hundred years, and they make no changes in it. They are outside it in origin and additional and supplementary in result. The starting point of them all, the earlier occasional use which is now generalized into constant and regular practice, is the action of the king in special cases outside the ordinary processes of the state which has been described in the last chapter. He now gives up his exclusive right to initiate these processes, and throws open the possibility of their use on demand to any one who is willing to pay the required fees. I have spoken of this as change, and it is change in a most 
important respect, but not in the sense that it substitutes a new for an old way of doing things. New methods of doing the same things are introduced alongside the old, but they do not modify the old, or for the present cause any of them to disappear though they will do this in time.

More in detail, the king's writ, ordering a thing to be done, is opened to general use. Anyone may have such an order on application in a large range of uses. The king's jury, as a most effective method of getting at the facts in dispute, is also thrown open. The king's commissioner specially appointed to try a given case or to look into some interest of the king's, is transformed into a new local court visiting the counties at regular and specified intervals, having for one of its chief duties to superintend and operate the new processes. And finally as a means of keeping this machinery in constant operation, the new court of special commissioners is generalized into a central court of the same functions permanently in session. ${ }^{3}$ The writ is the operative organ of the new system by which it is set in motion and as such it undergoes a rapid development in the multiplication and classification of its forms, which is interesting both in itself and in the evidence which it gives that the development of these new processes is a subject of careful study by those who are carrying it on. ${ }^{4}$ In a word, 3 On the origin and relationship of the permanent central court, see note A at the end of the chapter (p. 136).

4 We have many examples of the writs of Henry I. which have been 


\section{ORIGIN OF THE ENGLISH CONSTITUTION}

we may say that the king had made great progress towards setting up over against the feudal machinery of the state, another independent government machine, having its motive force and authority in himself, bringing the royal authority, as a protective power, within reach of every freeholder in the state, and of every man injured by a crime, and sweeping away to this extent all limitations which had been set to the king by feudalism. In doing so he had created a machine of general government finding its sole motive power in the king, and capable of easy application to other functions, like taxation and legislation.

The first of the legislative enactments by which these changes were made which has come down to us in documentary form is the Assize of Clarendon of 1166, the word assize having in this instance the meaning of an act of legislation. The Assize contains

preserved to us in Vol. II. of the Chronicle of Abingdon and similar monastic collections. If we bring a large number of these together and compare them with the writs in Glanvill, it is evident that in the intervening history of the writ two processes have been going on. In the first place much attention has been given to the language of the writ to make it specific, exact, and constant, and second, considerable classification of actions has gone on and the principle that the writ must accurately describe the action intended has been so applied as to multiply the number of writs by a process like that of division and subdivision. These were, of course, the processes which continued for another century and which created the great body of English writs, the process of the first age in the formation of the common law, but it is here to be noted that it implies previous to Glanvill, and in his time, as expressed in that book, much careful study of judicial operation which must have been conscious and which may rightly be called scientific Facile est autem inde formare brevia juxta diversa negotia. Glanvill, II. 13. See P. and M., II. $557 \mathrm{ff}$. 


\section{THE FIRST AGE OF CHANGE}

twenty-two clauses and concerns a number of different subjects, but we have to notice particularly the following points. ${ }^{5}$

First of all it is evident that the king's special commissioner, the royal justice, is taken for granted. It is a not unnatural interpretation of the first clause that special commissioners are about to visit the counties to put in operation the process there provided for, but there is nothing in the document which explicitly says any such thing. Rather its whole tone is that the justice upon circuit is a well understood institution in frequent operation whose presence in the county may be expected regularly, or at no long intervals. ${ }^{6}$ This appears in the following facts implied in the Assize. The arrest of criminals under this act is to take place constantly. As soon as proper information comes to the sheriff, he must take the suspected man into custody. A part of the new process he may carry through himself but he cannot finish it. The final stage can go on only before the justice, and the sheriff must report his action to the justice as soon as it has taken place; the justice may be coming to the county in the immediate future, if not, he is likely to be found in some neighboring county, and there the sheriff's

5 The text of the Assize of Clarendon will be found in the original, in Stubbs, S. C., pp. 143-146, and in translation in Adams and Stephens, Select Documents of English Constitutional History, pp. 14-18, and Penn. Transl., I. 22.

6 P. and M., I. 153; Stubbs, Gesta, II. lxii. ff ; Ralph de Diceto, I. 434435. 
messenger must seek him out and receive direction as to where sheriff and prisoner are to come before him to complete the trial, plainly not always in the county in which the arrest was made. Sheriff and justice are spoken of as if they were, one as much as the other, fixed and understood elements of the existing situation which the legislation assumes. Thus the document indicates with a fair degree of certainty that at some earlier date than 1166, whether in the reign of Henry II. or earlier still is not implied, the royal commissioner who acts in the first two Norman reigns on special occasions only, had become a regular and expected part of the system of public justice. At what date, in what reign, we do not know. No legislation on the subject has been preserved to us and the Assize of Clarendon contains none, but from what evidence we can piece together of the existence of itinerant justices in the reign of Henry I. and from the degree of familiarity with the institution which the Assize of Clarendon assumes on the part of every body to whom it is addressed, we cannot be far wrong in holding that what had happened in the dozen years of Henry II.'s reign already past was rather a revival than a new foundation. It is probably then only in this sense that we may include the itinerant justice among the new creations of the period, noting here again that in any case all that was new was making an extraordinary and occasional institution into one regularly recurring. 


\section{THE FIRST AGE OF CHANGE}

The second thing to be regarded is a method of detecting and trying criminals and this has every appearance of being new. What this method was we shall understand most clearly if we recall the king's prerogative process for ascertaining any fact which could be established by local knowledge as it has been already described: the justice puts certain selected men of the community on oath to tell the truth, to give a veredictum, and requires them to report as a body what they know about the specific question, or questions, submitted to them. In the first clause of the Assize of Clarendon we have merely a specific application of this jury process, though possibly to a new set of facts.

The matter to which it was applied-the repression and punishment of crime-was one which Henry II. had apparently found on coming to the throne to demand immediate attention and to be very difficult to deal with. At the moment when the Assize of Clarendon was adopted, the king was in the midst of the conflict with Thomas Becket, which had grown out of his attempt to recover some portion of criminal justice from the courts of the church. The problem to be solved, and it really was solved, by the Assize of Clarendon was a somewhat different one-to find out in the first place who had committed a given crime and then to make it sure that his trial should be adequate and speedy. To the first part of this problem the application of the jury method is so obvious that 


\section{ORIGIN OF THE ENGLISH CONSTITUTION}

we are tempted to express surprise that it had not occurred to some one before this date. So far as we know it had not. Once seen, however, the application must have been extremely simple. The state wants to know who committed a given crime in the hundred of A. It is highly probable that the men of the local community have their suspicions of the guilty party, perhaps know to a certainty who he was, though very likely the case will not be followed up and the crime will go unpunished if it is left to the operation of local justice.? If the king interferes, however, and demands of twelve of the more solid and trustworthy men of the hundred that under oath they inform his special commissioners appointed for that purpose of their suspicions, the criminal will not be likely to escape. Once suggested this procedure must have seemed most natural and simple to everybody. It can hardly have been thought of as an innovation at all, however new it may have been.

The place which the action of the jury took in the formal trial of the accused, the modification made in the procedure of the court, was, however, an innovation, and a most interesting one, but what it was and the way in which it came to be made is as simple and as easy to understand as the application of the jury to the first part of the problem. The trial of an ? Probably c. VI. of the Constitutions of Clarendon (Stubbs, S. C., p. 139) states the situation in many cases: Et si tales fuerint qui culpantur, quod non velit vel non audeat aliquis eos accusare. . . . See P. and M., I. 151 . 
accused man in the old popular hundred or county court passed through two stages, one which led up to and was closed by compurgation, and a second which might, and when a man had been found guilty probably always did, follow, ending in the ordeal. In these new trials in the court of the king's justice, called always the king's court, as in c. 5 of the Assize, the action of the jury already described took entire place of the first stage leaving only the second remaining of the old trial. To see how slight a change such a substitution would seem to make we must examine briefly the compurgation procedure of the older court. The hundred court was an assembly court. The judgment which it made was a mass-meeting judgment-the sense of the community. When we know its procedure in detail it is reduced to what looks to us a very cut and dried formalism and a case seems to go very mechanically to its conclusion. Now and then, however, we get glimpses even in late cases of more free action on the part of the court which are very instructive and it is not difficult to get back to the fundamental ideas upon which the formalism is based. It would seem that according to these ideas the right of compurgation - the right to make the oath with oath helpers which wins a man's case if he makes it successfully, is a privilege. It is not the modern burden of proof. Quite the contrary. The court awards the oath-the privilege of compurgation-to that one of the two parties to the case 
whose cause it thinks the more just. ${ }^{8}$ This is the first judgment, the intermediate judgment of the court, and it rests upon the public opinion of the community as to the merits of the case. That is why the formalism of the process gives the oath in all ordinary cases to the accused, or the defendent, the burden of proof naturally rests upon the complainant. But this judgment is only an intermediate one, the oath must follow it, that is, the court tries to make sure what the public opinion really is. It says to the accused: we are convinced of your innocence to this extent that we will allow you to see if you can find eleven men of standing in the hundred who will swear that they believe your oath when you swear that you are not guilty; if you

8 See P. and M., II. 600-603. The principle of the award of the oath is well stated in the Usatici Barchinone Patrie, c. 168. (Last half of the eleventh century probably. In Giraud, Droit Français, II. 501) ; Sacramentum non est probatio, sed in defectu probationis datur reo vel actori, cui judex certiorem esse cognovit et quem magis juramentum timere perspexerit, timere meaning not "to be afraid to take," but "having more respect for." Compare with this the case under William I. in Bigelow, Placita, pp. 17-18. See Bracton's N. B., pl. 1115. "It seems clear that in every case the presumption was in favor of the party to whom the vita was awarded," Professor Edward Jenks, speaking of the Scandinavian practice, E. H. R., July, 1896, p. 512. The formalism in the award of the oath is but little more than in the modern assumption that the burden of proof rests on the accuser or the plaintiff, and the burden of proof in the old procedure was often shifted by a new issue of fact raised in the pleadings, for example, see Bracton's $N$. B., pl. 1549, 1574. Ibid., pleas 531 and 1079 are cases where the medial judgment assigning proof is clearly a decision of the case for the defendant. In the case in the bishop of Bath's court in 1121, cited above, in n. 16, chapter II., the award of proof, by witnesses, to the plaintiff is in form a decision of the case in his favor, but it calls upon him to make a proof which it was probably well known he could not make. 


\section{THE FIRST AGE OF CHANGE}

can then we shall declare you innocent by the final judgment of the court. Or in more doubtful cases the court modifies the judgment and says: we think it likely that you are innocent but the circumstances against you are so strong that instead of eleven men you must find seventeen, or twenty-three, who will swear with you, or you must find so or so many from a given list of names which the court will make out; and probably many men would vote to let the accused make the attempt who, when brought to the test, would refuse to help him by taking the individual and specific oath as an oath helper. Obviously this is a primitive and clumsy way of getting at the public opinion of the community as to the guilt of the accused. It is the first stage of the trial only, because even when declaring itself plainly against the accused the sense of the community may be wrong - therefore there follows the ordeal, in theory an appeal to heaven not to allow human fallibility to work injustice. ${ }^{9}$

Now the relation of the jury's verdict to the older trial should be clear. It is a more effective and less clumsy, a more advanced method of getting at the opinion of the community about the accused. Easily and with no sense of violent innovation it takes the

${ }^{9}$ It is sometimes said that a man was ordered, or compelled to go to the ordeal. This should not be supposed to mean that he had no option in the matter. No man could be forced to submit to the ordeal who was ready to accept an adverse judgment of the court, but the ordeal was the only means of defense left for one against whom the compurgation process had gone and who still insisted upon his innocence. 
place of the whole compurgation portion of the old procedure, though it must have been clearly seen that it was new. The ordeal portion of the old procedure remains as it was, and for the same reason as in the popular court.

So far none of these changes could have seemed very extreme to the men of the time. But there is in the Assize of Clarendon another provision of a more unusual character; it must have seemed almost startling, one would think, if here proposed for the first time. It is in c. 5 and it provides that de illis qui capti fuerint per prædictum sacramentum hujus Assisæ, nullus habeat curiam vel justitiam nec catalla nisi dominus rex. In all cases of persons arrested under this Assize the feudal baron loses his jurisdiction, he cannot claim his right to try the case, and the financial advantage of jurisdiction, the right to confiscate the chattels of the condemned felon, goes to the king. With this provision go those contained in clauses 811, by which the privileges of exemption from the ordinary public jurisdiction enjoyed by the baron's lands, the immunity, called in England the "liberty," are suspended-the lands must be represented as other lands are in the court before the king's justices, the baron must permit the sheriff to enter to view the frank pledge, or to arrest the persons suspected of crime under the assize, nor can the baron harbor in his lands any person whom he is not ready to produce before the justices on their requisition. If we put 


\section{THE FIRST AGE OF CHANGE}

these things together, the result is this: everything that makes the independent jurisdiction of the feudal baron of value in these cases is taken away from him, the income which he derives from it, his power to exclude public officers from his lands and so to seem to possess some degree of political independence, and his power to protect his men from public processes. Before these specially commissioned king's justices, before these king's courts which they set up in every county, there was no feudal independence. The lands and the subjects of the strongest baron, exempt from all ordinary public jurisdiction, are as open to their supervision as the lands of the simple knight, or the common freeholder in the royal manor. ${ }^{10}$

There might be some reasonable excuse for a provision of this sort in the fact that the use of the king's private machinery, his commissioner and his jury, to maintain local order, ought to be paid for, and could

${ }^{10}$ It seems to me doubtful if we ought to say with Bigelow, Procedure, p. 101, note 3, that "some of the franchises held out against the entry of the sheriffs," so far as this legislation is concerned. At least no clear evidence of that fact has yet been produced. The legislation is in general terms, all inclusive, and without any indicated qualification. It should be so interpreted until the contrary is shown. That special exemptions from these regulations would be very soon granted, and when granted would be strongly insisted upon, is practically certain. There are, I think, before very long no regulations concerning the new prerogative justice from which exemptions were not granted to favored individuals, and corporations, or sold by the king. See Richard's charter for Dunstable, Cal. Charter Rolls, I. 9-an inspeximus. Every such confirmation or reissue of an earlier charter, as clearly expressed as this, would have the same effect. See John's charter in favor of William de Braiose, Madox, Exch., I. 150. $t$. 
be paid for most naturally by the chattels of the condemned. ${ }^{11}$ It is also true that in the charter of Henry I. in regard to county and hundred courts it is implied that in his county courts, before his justices, the privileges of the "liberties" in regard to attendance were suspended, ${ }^{12}$ but this provision goes much further than the mere matter of attendance. It strikes at the very foundation of the feudal state. It does to be sure have reference to one particular matter only, local criminal justice, but in that matter if this provision is carried out to its logical applications, the feudal state is at an end-the modern state has taken its place. Whether this result was understood by those whose interests were affected, whether there was opposition to it, whether the remedy for the failure of local justice was thought by any to be more dangerous than the disease, we do not know. Certainly it forms a part of the assize, that is, of a legislative enactment, and therefore it was adopted by consent. Later also, in the general indictment of the attitude of the Angevin house towards feudalism, it was not mentioned. It is, however, hard to believe that so complete an overthrow of feudalism in a matter so essential did not have something to do with the final judgment of the barons which led to the Great Charter.

11 The writer of the Dialogus de Scaccario does not seem to have considered this the reason for the provision. He sees that it is open to question and is manifestly at a loss to account for it. See II. 10, ed. Hughes, Crump and Johnson, p. 139.

12 See Appendix, II. p. 350. 
We are now able to say of the Assize of Clarendon that two great changes are either first enacted or are confirmed by it. They concern a single matter only, local criminal justice, but the extension of both to a wider range of interests would not seem to be difficult. By one, certain parts of the king's prerogative action, his justices and his jury, down to this date no part of the regular public machinery, in occasional use only for the king's own purposes, were fitted into the state's judicial machinery, as henceforth constitutional parts of it, as much so as the older courts, were given as it were by the king to the public, as the best way in which he could fulfill his high duty of making order and justice everywhere prevail. This would be in itself, if it were the only thing, a serious modification of the feudal constitution of the state, but the Assize goes further. In the second place it attacks one essential principle of feudalism-the representation of the state by the baron within his lands, his political rights and responsibilities for his men, and his local independence-and in this one particular destroys it completely. Whatever may be the importance of the Assize of Clarendon in the development of our criminal processes, the results to which these two changes naturally lead in the general constitution are of far greater importance. This is equally true whether the outcome is to be the highly centralized and absolute monarchy, to which they directly point, or by way of reaction, one of a different type. 


\section{ORIGIN OF THE ENGLISH CONSTITUTION}

So far these changes affect one point of the constitution only, and that as compared with the whole constitution a rather narrow point-the enforcement of criminal justice in the local subdivisions of the state. We have now to follow their application in a wider field, and to find our starting point we must go back to a date earlier than $\mathbf{1 1 6 6 .}$

The Assize of Clarendon is the first of the surviving legislative acts of Henry II.'s reign, but it is not the earliest of the documents which have come down to us, embodying the reforms which he was striving to carry through. The Constitutions of Clarendon is of the date $1164 .{ }^{13}$ It purports not to be an enactment, but a recognition, that is, a report to the king of the findings of a jury, a jury of what sort and size we do not know, perhaps a great jury of the whole kingdom, regarding the old and customary rights of the king and kingdom with reference to the church. Consequently in theory its purpose is to state old law, not to make new. The men of feudal days, however, did not hold themselves closely to definitions and distinctions, even when they knew them well enough, and c. IX. of the Constitutions contains one provision which, so far as we know, is new. It gives to everybody the right to use the king's jury, before a king's

13 Text in the original, Stubbs, S. C., pp. 137-140; in translation, Adams and Stephens, Select Documents, pp. 11-14; also in Gee and Hardy, Documents Illustrative of English Church History, pp. 68-73, and in Penn. Transl., I. 26. 


\section{THE FIRST AGE OF CHANGE}

justice of course, ${ }^{14}$ in one civil suit-a suit to determine whether a fief, a fee, should be held by the church, or if so is held by the usual feudal services or a fee in alms, that is, free of such services. Now it will be noticed that c. IX. speaks of the submission of this question to a jury as if that were nothing new, and we know also that in special cases permission to have such a question decided by a jury had been. granted before the accession of Henry II ${ }^{15}$ We know also that this privilege came to be called the assize utrum, as if the right to use a jury had been thrown open to the public, had been granted to anyone who would make proper application, by a special legislative act, like the Assize of Clarendon. This was very likely the case, and if this assize was of a date earlier than 1164 as the language would seem to imply, c. IX. is not really legislative in character; it states what had already become law. But such an assize has not yet been discovered, and so far as our evidence goes it is c. IX. which makes this use of the jury public. Whether this was really the case or not, here is at any rate evidence that in one sort of civil suit the same thing had been done that we have seen done in criminal cases by the Assize of Clarendon-the jury had been made a part of the fixed machinery of the judicial system. It should not be overlooked, however, 14 It should be noticed that the Constitutions of Clarendon assume the existence and thoroughly understood position of the king's justice as clearly as the Assize of Clarendon.

$15 \mathrm{P}$. and M., I. 145; Haskins, A. H. R., VIII. 633-635. 


\section{ORIGIN OF THE ENGLISH CONSTITUTION}

that in this case, after the question of fact is once determined by the jury, the jurisdiction of the feudal baron is carefully preserved.

Evidence that the use of the jury is allowed to all in a further range of civil cases is furnished us in the so-called Assize of Northampton of $1176 .^{16}$ In c. 4 of this Assize it is provided that, when the lord denies to the heir of his deceased vassal possession of his fief, the king's justices may ask a jury to determine what sort of possession of the fief the ancestor had as a necessary step in determining whether the heir should have possession or not, and this much at least of the question of inheritance is removed from the jurisdiction of the baron's court. With this goes c. 5 of the same Assize, which provides that in case of any recent disseisin the justices may direct a jury to declare the facts on which possession should be based. The clause speaks of such a disseisin as made super Assisam, implying the opening the jury in such cases

${ }^{16}$ It is not easy to determine the exact character of the document called the Assize of Northampton. Down to c. 5 it seems most natural to call it a legislative act, from that point on it seems even more clearly a commission to itinerant justices. The absence of any words of legislation, of anything corresponding to a de consilio et assensu clause, together with the fact that a memorandum as to legislation just adopted might naturally be included in a commission, inclines one rather to the belief that this document was not intended as a record of legislation, that record has perished, but only as a commission. See Gesta, I. 107. The very informal character of this document, if we may be sure that we have the whole of it, shows that contemporaries did not always stop to make carefully the distinctions which they certainly understood. Original in Stubbs, S. C., pp. 150-153; translation in Adams and Stephens, Select Documents, pp. 20-23. 
by an earlier act of legislation. These are of course two of the three "possessory assizes," morte d'ancestor, novel disseisin, and darrein presentment, a more full account of which is given us in the book on the laws of England attributed to Glanvill and written not long after the date of the Assize of Northampton. With them should go the grand assize, also described in Glanvill, by which the defendant whose possession is attacked, is granted a jury to decide not the mere question of temporary possession, but where the real right of ownership lies and so the final right of possession. ${ }^{17}$

It is not necessary to carry this account further. If these five "assizes," the assize utrum, the three possessory assizes, and the grand assize, be taken together, they will be seen to be applicable to a large part of the most important cases which could arise as to the holding of feudal land. The questions which they are intended to settle arose in probably more than half of all cases of litigation respecting land. ${ }^{18}$ Now with regard to them the same two things are to be noticed as regarding the provisions of the Assize of Clarendon about criminal justice: the jury is made a regular part of the constitutional judicial machin17 Glanvill, II. 7, 1 clearly states that the grand assize was established by an act of legislation. It was clementia principis de consilio procerum populis indultum, and it is several times called a constitutio. Compare Bracton's statement, f. $164 \mathrm{~b}$, that the assize of novel disseisin was provided de beneficis principis.

18 See Maitland, Rolls of the King's Court, Richard I. (Pipe Roll Soc.) Introd.; Equity, p. 329. 


\section{ORIGIN OF THE ENGLISH CONSTITUTION}

ery, anyone can have it who applies for it, if he pays the fees, and the jurisdiction of the baron's court is so far forth destroyed. Of them we must say, however, the same as of the new process for the punishment of crime. We do not know of any opposition or objection to these measures. ${ }^{19}$ In truth when we come to the great attempt to restore the balance between royal rights and feudal rights, in Magna Carta, with an inconsistency, as compared with other

19 The king's concession to the holders of liberties-so frequently made in the case of the monasteries-that the royal justice shall sit in the court of the liberty and there perform his function as itinerant justice, holding the assizes among other things, may indicate indirectly such opposition, but not exactly to the point here chiefly in mind. What is safeguarded by such concessions is so plainly the finazcial interest of the lord of the liberty in the cases tried, and there seems to be so little care for judicial or political independence, that other evidence on the point is necessary before the statement of the text should be seriously modified. Cf. Brunner, Schvourgerichte, p. 301, citing a charter of John for the church of Beverley which says that the liberties granted the church in nullo depereant, vel minuantur vel lædantur per assisas vel recognitiones vel constitutiones postea factas, but that recognitions and assizes are to be held in the court of the provost of Beverley. From Houard, Anc. Loix, II. 287. That is, if they are held in the court of the baron by a king's justice the liberty is not diminished. The statement on this point in Bigelow, Procedure, p. 78, seems to me too strongly worded. While we do not know positively that such reason was alleged (cf. Ralph de Diceto, I. 371), there certainly could have been found, as far as England was concerned, abundant excuse for the baronial insurrection of 1173-74, which was so general throughout his dominions, in Henry's many infringements of feudal right. The king's demand that knights of new enfeoffment should be reckoned in a baron's liability for scutage (1166, Stubbs, S. C., p. 146) was, I think, quite without warrant in law. On the similar "augmentum" in the Norman Kingdom of Sicily, going back to the time of Roger I., see Haskins in E.H.R., XXVI. 662-664. The interesting suggestion is there made that Henry II. may have been influenced by a knowledge of the Sicilian precedent in his inquiries of 1166. 


\section{THE FIRST AGE OF CHANGE}

parts of the Charter, complete but unconscious, the barons allowed the continuance and demanded the regulation of the three possessory assizes. The great practical superiority of the royal procedure, the influence upon the final decision which it allowed to the actual facts of the case, adequately proved, instead of an appeal to the wager of battle, outweighed the loss of their private jurisdiction, or perhaps concealed it from their sight.

To get a full estimate of the extent to which this new system of royal justice was drawing out of private courts all cases of importance, and beginning to form a great body of centralized law, we should add to the assizes and criminal justice, the writ of right and the writ Præcipe already described, both very much developed under Henry II. and made as regular and constitutional as the assizes, if we may judge by the account of them in Glanvill. By these two writs practically any case whatever concerning feudal rights, and some others also, might be removed from the baron's court to the king's. It must be added also that all these cases go before special commissioners, king's justices, and always the king's permission must be obtained in advance. It is the writ which plaintiff or defendant obtains which transfers the case into the king's court and serves to the justice at once as evidence that the king's permission has been granted and as his authorization to go on with the case. 


\section{ORIGIN OF -THE ENGLISH CONSTITUTION}

To this point we have considered these changes under two aspects only-their enlargement of the constitutional machinery of the state on its judicial side and their effect on feudal independence. Another aspect of them must now be taken into account-an aspect of equal influence with reference to our final estimate of this age of constitutional advance. The court of the justice before whom these cases were brought by these writs and assizes was the king's court. It was curia regis. It is so called in c. 5 of the Assize of Clarendon, and it calls itself curia regis in official documents which it issued. ${ }^{20}$ Probably in this first age of the history of these institutions the words meant, to the justices and to all who had to do with the court, not a curia regis, not one species of a genus, but the curia regis, that is, the only existing court of the king in one of its phases. ${ }^{21}$ The idea of differen-

20 In the fine-the finalis concordia-made in the itinerant justice courts, or in the permanent central court corresponding to them, as in the following of 1192 from the Ramsey Cartulary, I. 166: Hæc est finalis concordia facta in curia domini regis apud Huntedone, in octavis Assumptionis Beatæ Mariæ, anno regni Ricardi tertio, coram Ganfrido filio Petri, et Osberto filio Hervei, et Willelmo Ruffo, et Michaele Belethe, et Willelmo filio Ricardi, et Simone Pateshille, justiciariis domini regis, et allis fidelibus domini regis ibi tunc præsentibus. Other instances vary but little from this form. See Round in E. H. R., XII. 293; Glanvill, VIII. 3; Yorkshire Fines, Surtees Soc., vol. 94, p. vii.; British Museum Charters, vol. I., No. 55; Round, Feudal England, pp. 509-5IS. These words, which are an early stage of what becomes a formula, indicate that the king's justices are reckoned among the barones and fideles who form the court and that the court is an assembly court. On the justices as the barons' peers, see in note on Magna Carta, c. 39, at the end of chapter V. (p. 262).

21 See P. and M., I. 153. 


\section{THE FIRST AGE OF CHANGE}

tiation into distinct institutions was not yet possible. The justices-always more than one-who went down into the county to hold court were members of the great, the central curia regis. It was in this capacity that they acted as justices and in this capacity they probably had from the beginning a larger voice in making the judgment of the court than the presiding officer of the ordinary assembly court of the feudal age. The court through which they acted was an assembly court. They undoubtedly presided over it, but they were themselves as much members of it, as were the barons or the barons' representatives, who attended with them. ${ }^{22}$ In this capacity also they were competent to perform any function of the central curia which it might be desirable to have performed in the counties to which they were going.

We have now the third aspect in which this new judicial machinery should be regarded. By it the one

22 There is of course difficulty in understanding just how the presiding officer of the feudal or popular court, who is only a moderator and has only the Rechtsgebot, passes over into the modern judge with his modern function in the making of the judgment of the court. The explanation is very possibly to be found in the double position of the king's specially commissioned justice in these new courts, in that he was at the same time moderator as in the earlier courts, and also a member. of the court and an active participant in its functions. The special justices of the permanent Westminster court-common pleas-would naturally stand in the same double relation to their court, and from them the practice may have passed to the other common law courts, and have been made easy by the rise in these courts of a group of men, apparently from the last years of Henry II., who devoted themselves almost professionally to the administration of the law, and in its turn this made easy the development of the professional justice. I offer this only as a suggestion, but it seems something more than possible. 


\section{ORIGIN OF THE ENGLISH CONSTITUTION}

all-controlling and supervising institution of the central government, by which all officers were held responsible and unity of government was maintained throughout the land, was carried down into every local division of the state to exercise this supervising and unifying power on the spot. The advantage and the results are obvious and they were doubtless clearly seen by those to whom the institution is due. ${ }^{23}$ It is altogether possible that Henry and his councillors thought of the results obtained in efficiency of government, in practical centralization, and in an improved means of repressing crime, as of greater importance than in the furnishing to the freeholder of a better method of proving his rights.

If we regard the Assize of Northampton as a commission to itinerant justices, as we very well may, giving them instructions as to their duties on the circuit, and if we examine with it the commission to similar justices issued under Richard I. in 1194, ${ }^{24}$ we can see how fully this function of the justices was exercised and what proportion it assumes in their instructions. Every interest of the king in the county is to be looked after, and many of the functions of the sheriff may be for the time transferred to them. Their duties of this kind imply always that misconduct on the part of the sheriff can hardly escape their knowl23 On the objects sought in the establishment of the system see Ralph de Diceto, I. 434.

24 Stubbs, S. C., pp. 258-263; Adams and Stephens, Select Documents, pp. 29-33. 


\section{THE FIRST AGE OF CHANGE}

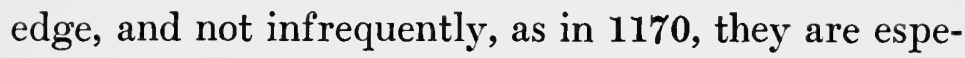
cially commissioned to investigate his administration of office, and find out what truth there is in complaints against him which have reached the king. ${ }^{25}$ If we put together the Assize of Northampton and the commission of 1194, the list which we can make of the administrative and executive duties which they were to perform is a fairly representative one. They are to receive oaths of allegiance to the king; to find out and look after cases of confiscation of property, of escheats, wardships, and marriages, of presentations to churches belonging to the king, and of the chattels of deceased crusaders, and chattels, lands and debts of Jews; they are to see to the destruction of unauthorized castles and to the custody of those belonging to the king; to look into violations of the assize of wine and the use of false measures generally, to see to the election of coroners, to lay a tallage and to inquire into the receipts and arrearages of the aids recently taken for king's redemption, and into the revenues and stocking of royal demesne manors and of escheats and wardships in the king's hands. Other duties assigned to justices might be added from other documents of the century, and similar instructions continue to be repeated in their commissions throughout the thirteenth century, but it is sufficiently clear both that the office is a flexible one easily

25 See a writ of 13 Edward I. in the Chronicon Petroburgense (Camden Soc.), pp. 103-104. 
adapted to any desired purpose and that the range of local supervision is very wide. ${ }^{26}$

For our purpose these new processes taken together mean a tremendous engine of centralization-an enormous relative increase of the practical efficiency of the royal government-an increase obtained wholly at the expense of feudalism by transforming older special prerogative processes of the king's into regular constitutional machinery and without changing their royal, non-popular, and non-feudal character. The absolutism of the early Norman kings is now intrenched in the machinery of the constitution. It is no longer a mere absolutism of force, founded upon the lack of any constitutional means of limitation and backed by occasional and irregular institutional action. It has begun to be a constitutional absolutism. It has entered upon the road

26 For capitula of inquiries to be made by the justices at the middle of the thirteenth century see Ann. Burton, pp. 330, 337; Cart. Glouc., II. 276. For the variety of commissions and distinctions between them, and for changes in form during the century, see P. and M., I. 179-181; Hall, Formula Book of Legal Records, p. 192; McKechnie, p. 329. Special commissioners continue to be appointed in the thirteenth century to make particular inquiries, to hold a court in a given place, to look into a single case, etc. See Cal. Pat. Rolls, 1247-1258, pp. 155, 156, 159, 160, 161, and many other instances. Cf. ibid., pp. 519, 525, commissioners to correct an error in a plea before the justices last in eyre in the county of Gloucester. See also the case of the sheriff too strong to be dealt with by the itinerant justices who is punished by special commissioners, M. Par., V. 580; Cal. Pat. Rolls, 27 Jan. 1257, pp. 539 and 551. Matthew Paris seems not to have risen above the idea that the chief purpose of the itinerant justices was to extort money for the king's use, and if his account is to be accepted others of his time had not. IV. 34, 186, V. 327, 458. 
which will lead to an absolutism of an ideally perfect type when the remaining rights and privileges of the feudal baron have gone the way of his judicial rights. His rights which remain are large, however-his rights of consent, his various property rights and exemptions, and his right as an equal party to the fundamental feudal contract, and the work of erecting a constitutional absolutism, ideally complete, is only begun. It has never yet had a full reckoning with the fundamental principles of feudalism, and it may never be completed if the baronage is by any means brought to understand the result to which things are tending.

The development is enough, however, already to create by far the strongest central government in Christendom. It is enough to explain why a king like Richard I. could neglect utterly all duties as king, at the height of the feudal age in Europe, with no result of anarchy in the kingdom, and why such enormous sums could be raised for his ransom and for his continental wars with so little evidence of opposition or of difficulty. It explains also why John's iron rule, against the conscience of the church and the interests of the baronage, was so long endured. 


\section{ORIGIN OF THE ENGLISH CONSTITUTION}

\section{Note A. The Origin of the Court of Common Pleas}

$$
\text { (Page 111.) }
$$

IT hardly falls within the purpose of the text to discuss the origin of the three common law courts-and yet the discussion would be closely related to the subject of this chapter-the origin and organization of the new machinery of prerogative and centralization. The origin of the common law courts is a subject on which at present conjecture only is possible, nor does it seem likely that evidence will ever be found to give any real certainty to our conclusions. Still I think we must say that in all probability the court which became after a time known as the Common Pleas Court was different in its origin and stood from the beginning in a different relation to the permanent small curia regis from the other two courts. The account given in the Gesta, I. 207, of its founding is as follows: Itaque dominus rex moram faciens in Anglia quæsivit de justitiis quos in Anglia constituerat, si bene et modeste tractaverunt homines regni; et cum didicisset quod terra et homincs terræ nimis gravati essent ex tanta justitiarum multitudine, quia octodecim erant numero; per consilium sapientium regni sui quinque tantum elegit, duos scilicet clericos et tres laicos: et erant omnes privata familia sua. Et statuit quod illi quinque audirent omnes clamores regni, et rectum facerent; et quod a curia regis non recedercnt, sed ibi ad audiendum clamores hominum remanerent; ita ut si aliqua quæstio inter eos veniret, quæ per eos ad finem duci non posset, auditui regio præsentaretur, et sicut ei et sapientioribus regni placeret terminaretur. This account, I think, we can trust for the general fact and for such details as are given. The author of the Gesta, whoever he was, had a knowledge of institutional matters unusual in a chronicler, and his technical language is, I think, everywhere accurate. If we deal with this narrative as we should with a documentary record, we shall get the following results: The court was instituted by a deliberate legislative act and its creation stood in close connection with the itinerant justice system 


\section{THE FIRST AGE OF CHANGE}

as that had been organized two years before (Gesta, I. 107). Difficulties had arisen in the operation of that system; these had been considered by the great council, and the new arrangement devised to overcome some of them at least. The justices of the new court were a special appointment, two clerks and three laymen, all of the king's household. They were to hear omnes clamores regni, that is, suits between parties, common pleas, arising anywhere in the kingdom. Nothing is said of any connection of these men with the curia regis, large or small, nor for a court so established would such a connection be necessary, though it would be probable. There is nothing to imply any intention to employ this court in king's pleas, but it would not be likely that a distinction in jurisdiction of this kind would be strictly maintained at so early a date, before men's minds had begun to be conscious of the institutional transformation which was going on. Such a distinction was very likely intended at first, however, because the difficulties which the people would wish to have lessened and which are spoken of as created by the circuits of the itinerant justices would in all probability concern their administrative business and the king's pleas, not their trial of common pleas, while this last would be, as indicated by the formation of the new court, what the community would desire to have continued and made more convenient. The jurisdiction of the new court, like that of all courts of the time, was final, but undecided questions of difficulty could be referred to the king and the sapientiores, that is, the council.

It seems beyond question that this court at its foundation was not regarded as itself the council, great or small. It was not the curia regis in the old sense, and in this more limited scope it differed from the itinerant justice court, though otherwise of the same type. It was a curia regis, but in the new sense-a court of special commissioners, a court growing out of the possibilities of the king's prerogative, exactly like the itinerant justices', except that it was a single central court for the whole kingdom. Like their court it would use from the beginning the new writ and jury processes which did not belong to the pro- 


\section{ORIGIN OF THE ENGLISH CONSTITUTION}

cedure of the old curia regis, and it would be limited in scope by the terms of the commission. If this is true, it follows that the permanent court for common pleas was not, as the later common law courts, King's Bench and Exchequer, seem most probably to have been, the small curia regis acting in a certain kind of business, and then as this business increased holding perhaps at first separate sessions to consider it, and so by imperceptible degrees becoming distinct bodies, though long showing many signs of the source from which they came. It was consciously a new creation; not an old body assigned to, or taking up a new use. It was treated afterwards as if it had the same origin as the other common law courts, but it actually began as a national and central itinerant justice court, which was always to be had when there was business for it, which did not itinerate, except as the king's court moved from place to place, and which concerned itself only with suits in which the king had no direct interest. See Maitland, Select Pleas of the Crown, pp. xi.-xix.; P. and M., I. 154, 169; Pike, Hist. of the House of Lords, pp. 31-41; McKechnie, pp. 311-315; Liebermann, Leges Anglorum, p. 63; Gesetze, I. 657, q; Round, Feudal England, p. 576, and elsewhere.

If this explanation is correct, it would follow on one side that in establishing this court there was no intention of doing away with the itinerant justice system, but only to render it less burdensome and more convenient. This fact is clear also from the chronicle, for we are told (Gesta, I. 238-239) that within less than a year England was divided anew into four circuits to which justices were sent, those going to the northern circuit being clearly distinguished in the account as the justices, now six in number, of the permanent court. The temporary suspension of the permanent court by the appointment of these justices to a circuit would seem to make necessary an arrangement of the business coming before these courts not unlike the later nisi prius custom. In this connection should be noticed the concluding words of c. 2 of the itinerant justice commission of 1194 (Stubbs, S. C., p. 259), vel a capitale curia regis coram eis missa, the whole capitulum referring specifically to the cases belonging 


\section{THE FIRST AGE OF CHANGE}

to the courts of this type. See Maitland, Year Books, Edward II. (Selden Soc.), IV. xxvi.; McKechnie, p. 330. On the other side the establishment of this new central court would interfere as little with the judicial function, or with the jurisdiction, of the later King's Bench. This fact appears to be clearly shown by the regi et sapientioribus of the Gesta, p. 208, to whom difficult questions were to be referred, and the old court would be more nearly coram rege than the new one, though it is evident that we can expect no strictness of definition for this term until the process of differentiation begins to be more consciously noticed. Nor is it likely that any distinction which could then be made would imply that the king was not considered to be present in some sense in the new court. This relationship of the two courts to one another would also be implied by the apparent absence from the membership of the new court, as indicated in the two passages in the Gesta, of any of those persons of high ecclesiastical or lay rank whom we should expect to find in the small curia. This characteristic is, however, not to be found in the groups of justices who are assigned to the circuits and it is not likely that it would be a permanent difference. It would probably affect only the earlier years of the new court's existence. Still I think care should be taken to distinguish in the records which have come down to us, so far as it is possible to do so, between these two central courts, the small curia regis and the new prerogative court, which might often be in session at the same moment, each doing business in its own way, at any time after the creation of the new court. Manifestly powers and functions belonging to the first, were quite beyond the competence of the second. See Maitland, Three Rolls of the King's Court (Pipe Roll Society), XIV. xxv.-xxvii.

If this explanation is correct, it follows also that we need not ask of "Glanvill's capitalis curia domini Regis how it becomes two courts, the King's Bench and the Common Bench or Court of Common Pleas" (Maitland, Select Pleas, p. xii.). It would not be necessary to suppose that such a separation took place, for it would exist from the beginning, the Common Bench being 


\section{ORIGIN OF THE ENGLISH CONSTITUTION}

the central court created de novo in 1178 and the King's Bench being included in the one jurisdiction of the small curia regis, the later council, undisturbed by the new creation, but to be set off by itself from the council in a somewhat later stage of differentiation. In this case the particular facts cited by Maitland, Select Pleas, pp. xiv.-xix., find a most ready and natural explanation, but we should expect parallel instances to occur at any time after 1178 if our records were as full for Henry II. and Richard as they are for John.

As to the peculiar prerogative processes, for whose general use and convenient application the new courts seem to have been devised, it would seem that, as belonging specially to the king, the employment of them by any king's court ought not to have been difficult, at least after they became thoroughly established as a matter of common use and habit, which would certainly be not long after the death of John. It is perhaps incautious to conclude that they were not so employed from the beginning in view of the scanty evidence which has come down to us. It is true, however, that the large curia regis never adopted them, nor did the small curia regis acting as council, whether in its transformed jurisdiction as equity courts, or star chamber, or in its retained jurisdiction as council. The small curia regis as council, regarded from the side of its judicial function, retains more of the character of the large curia, than it does when acting through the common law courts which are derived from it, just as in its general function as council it retains more truly the miscellaneous composition of the old curia regis than does the House of Lords when it becomes fixed in form as a part of the later Parliament. That these new processes are exclusively prerogative processes and do not belong to the curia regis may, perhaps, account for the fact that tenants-in-chief are required to pay liberally for their use. They would gain no right to them from their membership in the curia regis. With the increasing abundance of judicial records after 1216 , we ought to be able to detect more clearly than has yet been done, the transformation by which the two courts especially representing the earlier small curia regis, King's 


\section{THE FIRST AGE OF CHANGE}

Bench and Exchequer, became common law courts. Theoretically the process must have been largely one of usurpation, cutting into the field of the Court of Common Pleas. It must be studied largely as a question of procedure, the adoption by these courts of the new procedure, the procedure of the Common Pleas, and by that means drawing into themselves cases that should belong to the new court. Nor should the influence of the new court upon the origin of the King's Bench be overlooked, because the reference of difficult cases to the council emphasized strongly the coram rege feature which was apparently fully shared by the King's Bench in its early stages with the council proper. The influence of the new court and the new procedure was indeed most profound upon our whole judicial system.

The history of the differentiation of the small curia regis in the thirteenth century is a puzzling one. The chroniclers and occasional references in the records show us that the men of the time were beginning to make a distinction in their minds between different bodies which at another time, in circumstances when we should expect them to do so, they do not seem to make at all. This distinguishing seems to be mainly for purposes of description and does not arise from any clear perception of differences in institutional operation. Vaguely the different bodies into which the small curia regis was separating were coming to have different institutional spheres. Soon these will be understood and the different provinces well marked off and distinguished. But institutional distinctions were never so sharply made in this process during the thirteenth century as to prevent what seems to us confusion of composition and of function. We get into difficulties at once, I think, we try to do more than the thirteenth century could have done, if we attempt to straighten out the tangles made by this apparent confusion by deciding what one of the later distinct bodies is the principle one acting and what has been united with it or added to it in any given case. The perplexities disappear when we come to perceive clearly that what is going on is the wholly unconscious differentiation of a body having originally very complex functions into distinct bodies 


\section{ORIGIN OF THE ENGLISH CONSTITUTION}

functionally distinguished. But while this process was going on nobody saw any great difference between the bodies which were acting contemporaneously. They were separated, when they were, for convenience, and they were continually reuniting and separating and acting for each other and with each other with no sense of anything strange or institutionally questionable, as indeed there was not. Why not mix their records on the same roll? Why not use a parliamentary session of the council for judicial purposes? (P. and M., I. 200.) What would seem strange to the men of the thirteenth century, or of 1305 , is that any question should ever arise about such combinations. Probably it would have been impossible to explain the phrase "parliamentary session of the council" to a member of that body in 1305 so that he could be made to understand it as we do. To him it was a matter of course that the council should legislate and judge. These were as much its normal functions as any other. The other thing we find it hard to hold to firmly is that while the small curia regis throws off different bodies having different functions, it remains what it was with all its original variety of functions, and becomes the concilium ordinarium of later times. This fact is, however, a necessary key to much in the subsequent history. Unless we have it in mind we cannot understand fully the ordinances of the fourteenth century, the court of star chamber, the question of the legal force of proclamations, orders in council, or the judicial committee of the Priry Council.

There are certain cases recorded in which a distinction seems to be made more sharply and consciously than I have supposed above. Particularly interesting cases will be found in Bracton's N. B., pl. 1220 (Madox, I. 102 f.); Staff. Hist. Coll., IV. 122; and Cal. Charter Rolls, 1258, pp. 7, 309. I cannot be sure of course that I have discovered every case of this kind, but I think it will be found that such sharper distinctions, when they are made, are drawn between the Bench and other courts, and that they are to be accounted for by the peculiar origin of the court of Common Pleas, as not an off shoot from the small curia regis, which I have explained abore. The references here given, except 


\section{THE FIRST AGE OF CHANGE}

the first, show the institutional identity of the central court of Common Pleas and the itinerant justice courts.

The origin of the function of a court of errors is another question which can only be made a subject of conjecture. It seems likely that it will be found, if we ever obtain the facts, also to be closely connected with the development of the professional justice and the differentiation of the courts. Possibly as the fact begins to attract attention that one court is more nearly as a matter of actual practice connected with the person of the king than others, particularly than the itinerant justice court, and as there begins to exist a body of judges whose professional duty it is to know accurately the rules of law and procedure, it begins to be felt on one side that a breach of these rules should be at once repaired, and on the other that a court in which the theory of the king's presence is more nearly realized can, perhaps as a matter of prerogative, correct the errors of what must soon at any rate begin to be thought of as an inferior court. The practice of reserving difficult cases in the circuit courts nominally for the king would make the suggestion of such a process in errors easy. Such facts as we have seem to support a conjecture of this kind. Certainly there can be no procedure in errors until a differentiation of courts is under way. 


\section{CHAPTER IV}

\section{The Germ of the Constitution}

I have said that the great increase of royal centralization during the reign of Henry II. was obtained at the expense of feudalism, and that is true, but there is one qualification to be made. It was obtained at the expense of feudalism as that affected the rights and interests of the individual baron, and not as it affected the general constitution of the state. It is of the utmost importance to see that the older machinery of the central government remained during the next generation unmodified, however much added to, by the innovations of Henry II.'s time. Nothing was done away with; nothing was changed. It remained a feudal, public assembly, that is, curia regis, constitution, in which the active operative element was the baron, just as before, as primitive and crude as ever, doomed now to speedy disappearance, but still the chief reliance for carrying on the business of the state. Alongside it there had been established in the last generation other ways of doing some of the same things, ways more effective and more modern in character, but still closely connected with the old. They still rested on the assumption that the feudal baron was the necessary agent through whom busi- 


\section{THE GERM OF THE CONSTITUTION}

ness must be done, though the way had been opened for the rapid transformation of this idea into the other that it was to be done through the agent of the king. ${ }^{1}$ Really of course the new differed from the old most widely in the fact that it was based upon a different fundamental idea of the state from the feudal, ${ }^{2}$ but of this no man was at the time conscious, and the fact showed itself only in a closer connection with the king, a derivation of powers directly from him, and a consequent use of processes and rights which had no place in the purely feudal constitution.

These things have been sufficiently explained in the last chapter. Here two points are to be especially noticed in regard to the relation of the new institutions to the older constitution. In the first place, only a portion of the business of government could be performed by them, and second, no one of them was as yet compulsory, they were at most only alternative ways of doing certain things which still continued to be done in the old ways.

In the first place, the new institutions performed only two of the functions of government, the judicial and the executive or administrative - any traces of a 1 The assumption that the king's justice was a baron and was acting as a baron in holding his court was of course more formal than real, though it had important applications that were real. In truth the text should be modified by the fact that the substitution of a professional official for the feudal baron in doing so much of the business of the state was a long step towards making the baron no longer necessary and rendering the forming royal constitution independent of feudalism. As yet, however, there was no sign of this result.

2 See notes 24 and 26 below. 
legislative function are too slight to be taken into account. In the end their function was to be even less than this because, while the men of the twelfth century may possibly have regarded their administrative function as the most important, they survived in the modern constitution as judicial only. Administrative supervision was destined before very long to pass to new differentiations of the small curia regis. Second, in the exercise of these functions the new institutions, though in one sense generalized and regularized, opened to the use of all freemen, remained still occasional in operation. The itinerant justice with his new writs and his jury did not drive out of existence in this period the local baronial courts, nor the sheriff's county court, nor their methods of trial. Any person might if he desired to do so and was willing to pay the price demanded, make use of the new machinery, but he was under no compulsion to do so. He could still use the old courts and the old methods if he preferred. To a very large extent the saine thing was true of criminal justice. It was still possible for any given crime to be tried as if the Assize of Clarendon had never been adopted. Nor did the itinerant justice with his very effective means of holding the sheriffs in check take the place of the exchequer court. Again, it is not possible to find any reflex influence of the new institutions upon the methods and procedure of the corresponding portions of the old constitution. These new 
institutions had arisen as alternatives to the old, but at no point had they supplanted or modified them.

It is to be noticed further that the reigns of Richard and John added nothing to this body of new institutions. The tendency to innovation, if we may put it in that way, which had characterized the reign of Henry II. in producing a series of judicial and administrative changes, shows itself in the reigns of his sons in a tendency towards change in the financial system of the state, affecting the methods of obtaining revenue and its amount. This was probably the logical step for the second generation to take, but whatever may be the results in this direction finally traceable to the experiments of these two reigns, certainly at the time of the revolutionary movement, which closed the reign of John, no results had been reached of which we may say that they had become recognized parts of the constitution, or created regular methods in finance alongside the old, or still less which had modified or done away with them.

Now the conclusion, which it seems to me impossible to dispute, is this: England remained to the close of the reign of John a thoroughly feudal state. In spite of the innovations of Henry II.'s reign there had been' as yet no essential departure from the feudal type of government as seen in all the contemporary states of western Europe. ${ }^{3}$ One great difference of 3 The extent to which feudalism pervades the historical sources of the Norman and early Angevin reigns has hardly been sufficiently recognized. Had every other monument of feudal law disappeared it would 


\section{ORIGIN OF THE ENGLISH CONSTITUTION}

course existed, and this I have tried to make clear, in the powerful monarchy, the close centralization of the Anglo-Norman state. But of this difference it is to be said in the first place that while it had decidedly affected the practical condition of things usually found under a feudal government-the splitting up of the state into locally independent fragments whether that independence be regarded as territorial, or as political and judicial, as expressed in Glanvill, XII. 6, it had affected the general machinery scarcely at all-other machinery was occasionally in use, was coming into more and more frequent use, but it had driven the feudal out of use at no point, had nowhere broken the completeness of the feudal constitution. It is to be said in the second place that the methods and the results of the Angevin monarchy in its centralization of the state seem to be those natural to the transformation of the feudal into the modern constitution. France, for example, a few generations later and more slowly adopted almost identical methods with almost identical results. It is not the English absolutism which is abnormal; it is the English limited monarchy.

be possible to reconstruct almost the whole body of it from the second rolume of the $A$ bingdon Chronicle alone. By that I mean of course the living principles and practices of the tenth and eleventh centuries, not the more highly elaborated and technical law of the thirteenth century and later lawyers. Some other collections give more information still upon special sides of feudalism, as the Ramsey cartulary upon economic feudalism and the Gloucester cartulary upon the legal questions involved in the transfer and lease of land. 
I think, indeed, that we may say of the England of 1215 , regarding it as a state, and considering feudalism as one type of organization for carrying on the business of the state, that it is the most perfectly logical feudal kingdom to be found in Christendom. ${ }^{4}$ In other countries results which we consider logical outgrowths of feudalism are more plainly seen in local independence and political separation and diversity, but these results, while in one sense logical, are really obtained by an overemphasis of certain feudal principles, the rights allowed the vassal, or usurped by him, which destroys the balance of the constitution as a whole. In England the unusual emphasis upon the rights of the suzerain counteracted this tendency as seen in other feudal states and, while it did not take away from the importance, nor interfere with the function of the vassal, it did maintain the logical balance in the entire organization.

Now the bearing of all that has gone before is this:

The problem of the origin of the English Constitution is not the problem of the origin of specific institutions. It is rather that of ascertaining how, and, if possible, where, the constitutional development of that country branched off the line of growth common to medieval monarchies. At some point of time England entered a road new in history, trodden by no other people and leading to a result never arrived at 4 See note $A$ at the end of the chapter (p. 186). 


\section{ORIGIN OF THE ENGLISH CONSTITUTION}

elsewhere-full and free national self-government, under the forms of a monarchy and the theory of an unlimited kingship. But it did so from a constitutional beginning practically identical with France. France came out of the Middle Ages, however, with an absolute, and England with a limited monarchy. To find the how and when of this divergence is to fix the origin of the English Constitution. What we have tried to show to this point is that it is impossible to place the date of this divergence earlier than 1215 . We have followed the history of the constitution from the Norman Conquest to the end of John's reign and have examined its general character and the tendencies towards change which have appeared in it. The inevitable conclusion is that at the beginning of the thirteenth century England was still a completely feudal state, varying from its contemporaries not at all in the direction of a limited, but decidedly in the direction of an absolute monarchy. In all the changes which had occurred before 1215 there is no evidence of anything like the beginning of an institutional check upon the will of the sovereign. If the conditions of the time looked forward to anything it was to an almost ideal absolutism, a government in which all the machinery should be operated by the king and exist only to give expression to his will, with no means of limiting that will or even of giving expression to a will in opposition. The tendency which is latent in feudalism in the contract rights of 


\section{THE GERM OF THE CONSTITUTION}

the vassal to check the arbitrary action of the suzerain, which was so soon to bring about results of the utmost importance, had as yet shown no sign of development. The most that we can say about it is that in the reigns of Richard and John the barons were coming to recognize more consciously the existence of their definite rights and the possibilities they offered. Certainly this tendency had given rise as yet to no institutional forms of action. In the general constitution of John's reign, and in the individual institutions by which the constitution was operated, we find only what is common to all feudal states or peculiarities which mean a greater centralization and a more powerful kingship. ${ }^{5}$

As a matter of fact, this increased power John used to as full advantage as was possible for that time. I believe that the tremendous power which he exercised over a reluctant baronage and a hostile but cowering church, even until after the battle of Bouvines, though it had begun to weaken before that date, has never been emphasized enough. If one considers the situation carefully, especially after the ineffective interdict and excommunication, it seems impossible to state too strongly the utter powerlessness of every

5 In one sense we may say that this means merely that England was a feudal state of the type of a barony rather than that of a kingdom. The expansion of the feudalism of the duchy of Normandy into that of the kingdom of England had taken place without any essential change in the character of the relations between the suzerain and his vassals. Cf. A. H. R., V. 645 . 


\section{ORIGIN OF THE ENGLISH CONSTITUTION}

element in the state as against the king. I doubt if there is to be found a like instance of arbitrary power in medieval history in the case of a sovereign so nearly dependent on himself alone. To be sure John had been forced to yield in 1213, but he had yielded so suddenly and with such consummate skill in adapting what he did to the one real necessity of the case and no more, that his hold upon the kingdom was for the time being only slightly loosened. ${ }^{6}$ But whatever one may think of John's position, the situation on the eve of 1215 promised a very different outcome of English history from that which actually occurred. It is impossible to find in it any reasons for suspecting that England had departed, or was about to depart, in any essential matter, from the usual development of a feudal constitution, least of all in the direction of a limited monarchy.

If now, in seeking to determine the point at which the drift towards a limited monarchy begins, we turn to the time following 1215, we are confronted with a similar condition of things. It is indeed true that

6 . My argument in rolume II. of Hunt and Poole's The Political History of England, p. 424, for the view that John's act of homage was of his own policy, and not demanded by the pope, has been questioned. This view still seems to me decidedly the more probable. It is less important, however, to determine what one shall believe about a question which must always be a matter of opinion, than to see how indispensable the act was to John's security, and that nothing less would have averted the French invasion. I believe it entirely consistent with the political character which John shows throughout his reign to suppose that he saw this as clearly as we can and shaped his action accordingly. 


\section{THE GERM OF THE CONSTITUTION}

so far as feudalism is concerned there is evident at the close of the thirteenth century a complete and revolutionary change, as if there had occurred somewhere in the interval a night of the 4th of August and the meeting of a Constituent Assembly. Feudalism-true feudalism-had disappeared as a ruling system from the domain of both public and private law, or it would perhaps be more accurate to say that as a political and economic system feudalism was just transforming itself into its most permanent contributions to English institutions, under anything like the original form; on one side into the land law, even at that date highly artificial because based upon a system which no longer corresponded with the facts, and on the other side into the group of new institutions derived from the curia regis, of which the most important from a general point of view was the Parliament. But these changes did not essentially affect the character of the kingship and it is a hundred and fifty years after the date of Magna Carta before we can find any institution forming a permanent part of the constitution, that is, which is not merely a temporary experiment, of which we can say that it had for its object to secure the operation of a limited monarchy. It is generations of time in other words before we can detect any essential institutional departure from the type of the continental state which becomes a permanent part of the constitution and which we may be certain is in the direction of a limited 


\section{ORIGIN OF THE ENGLISH CONSTITUTION}

monarchy. All the constitutions which grew out of the feudal, including the English, were alike in their general features so far as the machinery of government was concerned. In all alike the curia regis, the great mother of institutions, gave birth to practically the same progeny, growing up to closely similar results. Peculiarities there were in each state, differences of detail, of form rather than of method or character; but England differs no more widely from what may be called the normal type than do other states, probably less than does Germany. Some of the English differences may be thought to be very essential elements of constitutional government, some details of the judicial system, some features of local government, the composition and organization of Parliament, and they certainly were of great assistance in the making of the constitution, but it did not come from them. All such peculiarities of the English Constitution taken together would never have produced a limited monarchy. It is indeed true that the constitution was practically completed, all its great principles were established, before institutions which may be said to be peculiar to itself had come into existence. They concern details, - not the general character of the government as a whole; no one of them furnished a unifying, organizing principle.

7 The process of impeachment is the first thing, I think, of which exactly this may be said, though of course by the end of the reign of Edward III. Parliament had made great progress along the line described below. 
They were brought together and made parts of the constitution by something outside themselves.

In fact the final constitution, to the present time, has consisted less in institutions that are peculiar to itself than in the fact that institutions common in their general form to many states have been used for purposes, to embody and protect ideas, not found elsewhere, and have been by degrees in consequence of such uses somewhat transformed in character. It was not by the development of new machinery of government that the difference between the French and English constitutions was brought about. It is elsewhere than in institutions proper that we must look for that which brings about the peculiar result. Were it not for the fact that we are often satisfied with explaining this difference by calling attention to such things as the jury, the survival of election, the composition of the House of Commons and the peculiar characteristics of the English peerage, it would not be necessary to insist upon this point with emphasis, because institutions are always results. The idea goes before the form. The thing in its reality is already in existence, or it is rapidly coming into existence, before it takes on the gruise of an institution.

It is to the realm of legal and constitutional ideas, then, that we must look to find the peculiar influence in English history which explains its peculiar result. There must have been present during the formative centuries, the thirteenth and fourteenth, some guiding 


\section{ORIGIN OF THE ENGLISH CONSTITU'TION}

and selective principle, actively influencing affairs from time to time and producing that transformation of constitutional ideals and uses which made the English unique among governments at the close of the Middle Ages and in modern times the model of most states.

It is easy to understand upon what point in the constitution as it existed in the early thirteenth century such an idea must bear; against what danger it must strive; what opposing tendency it must overcome. The direction in which the only tendency to constitutional change in England was setting has already been made clear. It was an absolute monarchy which was forming itself, which had already formed itself and which bade fair to drive all other forms of government out of the field. As feudalism began to give way before the new social and economic influences of the time, the one danger was that the king should retain over the modern institutions into which feudalism was changing the same absolute control under which he had held the feudal machinery, and this was all the more likely because the modern institutions were forming themselves out of the royal prerogative. A formative idea, shaping the English Constitution into a limited monarchy, must at the very start oppose the ideal of an absolute king, must proclaim that there was some limitation on his arbitrary will, on his prerogative power, and must set up limitations of such a sort as to admit of easy and 
constant enlargement. The tyranny of John could have been transformed into the constitutional monarchy of the Lancastrian age in no other way. A baronage determined to protect its privileges, an ambitious House of Commons, a third estate unusually influential in public affairs, could have made no such constitution except under the guidance of some general principle, by which all classes could work, in every generation alike, and which would grow consistently and continuously as the enlarging interests of men demanded. ${ }^{8}$

This guiding and creative principle is to be found in the idea that there existed a body of understood, more or less definitely formulated rights which the king was bound to observe and which those who at any point of time formed the operative force of the nation had the right to force him to observe if he showed himself disposed not to do so. ${ }^{9}$ In every case of open conflict between the king and the nation, or what stands for it, from 1215 to 1689 , this is the underlying assumption of those who oppose the king. $\mathrm{He}$

8 It may perhaps be thought that the establishment of such an oligarchy as that threatened by the Provisions of Oxford, presents a third possibility, but not, I think, in the actual situation in England. The baronage was too weak, between the king on one side and the third estate on the other, to give rise to any real danger.

9 I should not be understood to affirm that this principle-the king is bound to observe a specific body of law-is peculiar to England. The same principle is, to a greater or less extent, inrolved in the constitution of every feudal state, and in some cases, like Aragon and Hungary, it comes to very conscious institutional expression. It is only England, however, which makes it permanent and fruitful in modern governments. 
is doing something which he has no right to do. If he cannot be persuaded to change his conduct, the nation is within its rights not merely in forcing him to do so, but in binding future kings not to repeat these acts. This principle is imperfectly stated unless both parts are included in it. The second half, the right of coercion, was as essential a part of it as the first, more so, if that were possible, for without this right and its successful exercise the idea of a body of law above the king would probably have disappeared leaving behind it no practical result. If this is true, it follows that the real line of the early development of the constitution, of the events which by degrees called it into existence, is not the development of Parliament, but the line of the enforcement of this right of coercion. The history of Parliament is the history of the independent and unintended formation of the institution which finally, when the idea had become firmly established, was to assume its guardianship and enforcement; but the history of Parliamentary origins and growth is not the history of the origin of the limited monarchy.

I have said that for generations this idea was embodied in no peculiar institutions, and this is true. Men derised no successful machinery to give it permanent expression. But I do not mean to say that no attempt was made to create such machinery. It would have been impossible for such an idea to survive and to exert any real influence upon the course of constitu- 


\section{THE GERM OF THE CONS'TITUTION}

tional development except through some institutional expression however much the form of that expression might vary in different generations, or however transient any particular phase of it might be. There was in fact much experimenting. From time to time institutions were invented, and machinery set up with the conscious purpose of enforcing this principle, and with more or less definite hope of permanence. But nothing of the sort was really successful or lasted beyond the mere occasion which called it into being. There was, to be sure, a general likeness in all these early attempts. The cases under John, Henry III., Edward II., Richard II. and Henry IV. have a general similarity of method and character..$^{10}$ The vesting of royal powers in a commission, or the transferring of the direct responsibility of royal officers to Parliament were, one or both, typical features of all

10 There is a kind of Parliamentary control of appointments and of official responsibility to Parliament which seems to be developing in the last half of the reign Edward III., in the case of the treasurer, for instance, which is not exactly like that in the cases of 1258 or 1310. See Stubbs, II., sections 287-288. It has nothing revolutionary in character; it develops naturally out of the circumstances of the time and seems to promise something of permanence. But it does not prove to be permanent. The later Parliamentary control of government does not grow out of it. If one analyzes sharply the cases of all kinds where such early Parliamentary control was exercised, there would seem to be in their occasion, in the way in which they were brought about, three different kinds of cases. Those originating in a revolutionary situation, like the Provisions of Oxford, and the Lords Ordainers; a natural growth out of the immediate situation, as under Edward III.; and those cases where advantage is taken of a regency, or something like a regency, as in the time of Richard II. and Henry IV. They are all alike, however, in general character. 


\section{ORIGIN OF THE ENGLISH CONSTITU'TION}

the cases. But open assumption of the royal power, or of any royal prerogative, by Parliament, or by any commission in name or form a creature of Parliament, was not to be the way of the constitution. ${ }^{11}$

This early experimenting, of which the Provisions of Oxford is the most typical example, was all in the wrong direction, doomed to and deserving failure. And it possessed in no single instance any element of permanence. Each case grew out of a special situation and lasted only so long as the situation continued. Nor is there to be found any line of institutional connection between the cases. ${ }^{12}$ On every new occasion when it was necessary to apply the fundamental principle, a method was devised anew and, whenever any line of connection between two cases can be made out, it is at best only one of precedent

11 This very essential peculiarity of the English Constitution, that in form and theory Parliament does not exercise the sovereignty, nor directly appoint or depose the agents of government, while really supreme, was secured by the relation of Parliament to the origin of limited monarchy described above. It did not become the instrument by which limitations were enforced upon the king until it had itself so far developed as to have become independent, to have found its proper place in the constitution in relation to the other institutions of which that is composed, and especially until its relation to the king had become well established. It was of exceeding advantage also in this respect that final trial of the issue between king and Parliament as to the place where actual sovereignty should reside in the constitution was deferred to the seventeenth century. The true drift of things had by that time begun to be perceived or, it would perhaps be better to say, was rapidly made apparent.

12 The demands for the confirmation of Magna Carta do form a continuous line of connection, but a line not of institutions. They express rather the idea which lay behind all the experiments. I shall later have something to say of these demands. 


\section{THE GERM OF THE CONSTITUTION}

and remembrance, and not of the continuous growth of an institution. Even precedent does not accumulate. No advancement is apparent. No later case builds on its predecessors, or goes on to improve what had been before into a more perfect or lasting instrument for controlling the king. The instances are individual, disconnected and unprogressive, but, as they are all instances of enforcing upon the king responsibility to the constitution as it existed at the moment, the fact cannot be taken to prove that in the meantime the fundamental principle had fallen out of sight.

But while this abortive experimenting had been going forward, there went on a quite independent line of evolution which is characterized by all that these attempts lack. It is continuous, cumulative and progressive. At first it had nothing to do with the coercion of the king, gradually more, and from the end of the fourteenth or early in the fifteenth century it absorbed into itself the line of experiments which before had been without permanent result, and became the sole guardian of the interests of the nation as against the king. ${ }^{13}$ This is the evolution of

13 I think we may say that Parliament begins to assume this position in the first period of the reign of Richard II., though of course its action at that time had been prepared for and led up to by the history of the last years of Edward III. The reign of Richard is characterized by the great rapidity with which Parliament becomes conscious of its power and by the fact that the baronial opposition acts now quite as much in and through Parliament as outside it. Richard's own policy after his second marriage is, I believe, to be most reasonably accounted for by 


\section{ORIGIN OF THE ENGLISH CONSTITUTION}

Parliament, or to distinguish and to name that which really evolved and which brought about the great result, it is the evolution of the House of Commons. That evolution, so far as we are concerned with it, however, did not consist in any perfection of Parliament as an institution. The constitutional result was not reached because there were two houses instead of three, nor because the minor nobility united with the burgesses to form the House of Commons, nor because of the growing definiteness of the constitution and organization of Parliament as the fourteenth century went on. Improvement of Parliamentary machinery assisted the process, but only by rendering it easier and more likely to be continuous.

What made Parliament finally the embodiment of the fundamental principle of the constitution was the fact that through the whole fourteenth century it had been steadily enlarging the body of law which the supposing that he also saw clearly what Parliament had become and the danger to the monarchy which it threatened. It is in the next period, however, that Parliament assumes a constitutional power almost modern, though exercised by means more closely related with the past than with the future. It was for this reason, probably, that the permanent results of the Lancastrian period were less important institutionally than as fixing the position of Parliament and creating a habit of opinion about its function in the state and relationship with other institutions which carried it without loss through the Tudor age. Statesmen as keen as Henry VIII. and Thomas Cromwell perceived at once how easily and peacefully revolution could be imposed upon the nation if Parliament's constitutional power was employed to bring it in. In this way the absolutism of the sixteenth century prepared the way for the increasing clearness with which, during the first half of the seventeenth century, understanding was developing, not merely of constitutional government itself, but of the ground of right on which it rests. 


\section{THE GERM OF THE CONSTITUTION}

king must observe, and in most important particulars. Beginning with and assuming control of the specific principle that there should be no taxation without consent, Parliament gradually made clear its bearing and enlarged its scope to include all sources of revenue except those of the feudal suzerain, and indeed encroached most seriously on these in the matter of tallage. From this vantage ground it reached forward to the assertion, not yet fully understood in all its bearings, that the king's expenditure of his revenue should be limited by the specifications of the grant. During the same time in a different direction, Parliament was making another addition to the law which the king must obey, more difficult and also more significant and decisive, because wholly new. This was the establishment of the principle that the House of Commons must be consulted and consent to every new act having the force of law. In demanding that its consent should always be obtained to taxation, Parliament was only assuming to itself the exercise of a right of the individual vassal which the feudal law had clearly and everywhere recognized and which the great council, as standing for the class, had assumed before the existence of Parliament in c. 12 of Magna Carta and throughout the reign of Henry III. As the feudal income broadened out to meet the exigencies of the modern state, Parliament insisted that the principle of consent should broaden also to cover all forms of taxation. This was a logical 


\section{ORIGIN OF THE ENGLISH CONSTITUTION}

demand, and even a king like Edward I. found that it had been so strongly fortified by the earlier events of the thirteenth century that it was not possible to resist it, and he was forced against his will to restore it to the Great Charter. But in assuming an exclusive right to make new laws, and particularly in asserting a right of consent to new law for that wholly unfeudal institution, the House of Commons, the Parliament of the fourteenth century was taking a position in which it could find no support in the old feudal constitution and which was an enlargement of the law above the king almost revolutionary in character. It is likely that no such assumption could have been made, and clearly it could not have been established but for the progress which Parliament had made in the matter of taxation. There had been very little that may be called new legislation in the modern sense during the feudal age, but what there had been was the act of king and curia. In this, as in other respects, there had been no distinction between the great and the small curia, and in this, as in other respects, the functions of the old curia regis descended along the line of the council as legitimately as along that of the House of Lords. ${ }^{14}$ For Parliament to

${ }^{14}$ See The Descendants of the Curia Regis, appendix I., p. 343. It is to be said in modification of the text that some distinction did exist between the two bodies in practice, but it was like that which existed between them in the judicial function of the curia. It was based on the importance of the case or of the parties concerned. It was a distinction of fitness, of convenience, determined by the specific occasion, and not growing out of a difference of function or of right. In other words it 


\section{THE GERM OF THE CONSTITUTION}

assert that an act of legislative character by the king and the upper house, or by the king and the council, must not have the same force as a statute, was to go counter to all precedents not merely of feudalism at its height, but of the thirteenth century as well. But this it did assert and in the end, so far as the main point was concerned, the king yielded.

But it was not alone, though chiefly, by enlarging the law which binds the king that Parliament was becoming the guardian and creator of the constitution. In beginning to audit the treasurer's accounts in the reign of Edward III., in the party struggles of the close of that reign and the first years of the reign of Richard II., in the application of old principles and forms to the new use of impeachment, in the coercion of Richard in the first part of his reign, and in the successful revolution at its close, Parliament was advancing by other steps than the making of new law to stand in the balance over against the king, and to assume the direction of constitutional growth. This is the period, the last part of the fourteenth century, when, as I think, the two lines of

was not a distinction of an institutional nature. Probably to complete the explanation of this legislative advance there should be taken into account the rapid dying out of political feudalism, and indeed of the most fundamental feudal distinctions, which accompanied the early stages of Parliamentary history. Had the feudal point of view been retained, even no more perfectly than in the first half of the reign of Henry III., it is likely that the derelopment would have taken the more normal form of a coördinate, rather than a supreme legislative right in Parliament. See note B at the end of the chapter (p. 194). 


\section{ORIGIN OF THE ENGLISH CONSTITUTION}

development which had been going on independently, the natural development of Parliament and the line of experimenting in methods of coercing the king, really coalesce into one, and henceforward the natural development of Parliament and its powers is at the same time the natural development of the limited monarchy. The Lancastrian period, startlingly and prematurely modern when considered constitutionally, is an age when the idea and practice of Parliamentary leadership grew familiar and came to seem the natural and traditional order of things, not with all the fullness of understanding of later times, it needed the struggles of the seventeenth century to produce that, but clearly enough to insure their permanence. As compared with so important a result as this, we cannot say that the establishment of freedom of debate and the other privileges of Parliament, or of the control of elections which characterize the fifteenth century, are essential enlargements of the law to which the king was subject. ${ }^{15}$ The age which followed the Lancastrian was one of suspended activity, or of reaction, or more accurately it was one during which Parliament gained the same degree of control over the ecclesiastical organization of the state which it had already acquired over the political.

15 The practical importance, however, of a case arising under these rights, the case of Goodwin vs. Fortescue, at the beginning of the reign of James I. should not be overlooked. It brought the king face to face with the constitution, and taught him the existence of a body of law which he could not contravene. 


\section{THE GERM OF THE CONSTITUTION}

At its beginning the answer of a Yorkist House of Lords to Richard of York's claim to the throne is a constitutional landmark of the utmost significance, ${ }^{16}$ and in many ways it might be shown that the English Constitution of 1460 was of a type new to the world. Into the details of these later times we do not need to go for our present purpose.

We now return to a more specific formulation of our original problem: from what source and at what time did there enter English history as an active influence the principle that there is a body of law above the king which he may be compelled to obey if he is unwilling to do so? And, it may be added, how did there begin a line of experimenting in the embodiment of this principle in institutional forms? It is the thesis of this book ${ }^{17}$ that this principle was derived directly from feudalism, and that it was the work of the Great Charter of $\mathbf{1 2 1 5}$ to transfer it from that system then falling into decline to the newer governmental system just beginning to be formed, and in so doing to give it its first institutional expression. In this fact we have, I believe, the explanation of the influence and significance of the Great Charter in English history. ${ }^{18}$

16 See Stubbs, III., section 677; Rot. Parl., V. 376.

17 See A. H. R., V. 650 (1900); and The Political History of England, II. 439 (1905).

18 It has been suggested that in this opinion I have followed Professor Maitland. In one sense this is true. My publication did follow his; see Pollock and Maitland, History of English Law, first ed., I. 152 (1895). But, what I understand the suggestion to mean, that my view of the 


\section{ORIGIN OF THE ENGLISH CONSTITUTION}

That there was in the feudal system of things a body of law, of recognized right, which the highest suzerain, the lord paramount of the realm, could not violate, hardly needs, I think, to be proved to anyone

Charter was derived from his, is certainly not the case. I have been very glad to find myself reaching the same result as so distinguished a scholar, and the fact has undoubtedly given me greater confidence in my conclusions, but those conclusions were entirely independent, reached by a different road and resting on a different body of fact. My original approach to Magna Carta was not through English history or law, quite the reverse; nor was my present understanding reached by an analysis of it as primarily an English document. I came to the study of it directly from the study of continental feudal institutions and law with which I had occupied not very abundant leisure for some years. Called upon for class-room purposes to read the document carefully for the first time since my special interest in feudalism had begun, I remember well the astonishment with which I recognized the fact that it was practically pure feudal law both in its details and in its underlying principle. There speedily followed the conclusions that England must have been a thoroughly feudal state, as I had not before supposed it to be, and that in the fundamental principle of feudal law, which is also the fundamental principle of Magna Carta, we have the explanation of the influence of that document in English history and the key to the origin of the limited monarchy. It was this conclusion which turned all my interest to the study of early English history to which up to that time I had given no attention, and it was reached before I had read the History of English $L a w$, or to my present recollection any other of Professor Maitland's writings. It led me to their study. His conclusion appears to me to rest on an analysis of Magna Carta itself, and I do not understand that he ever fully appreciated its relation to feudal law in general, or developed in his thought, as he could hardly have failed to do if he had given attention to the point, the relation of the fundamental principle of Magna Carta to the origin of the constitution, nor do I know that he ever connected with it the second half of this principle, the right of coercion, which is equally important with the first. I have stated these facts so fully not from personal reasons merely, but because it seems to me one method of asserting with emphasis that $I$ believe it to be indispensably necessary if one would understand the origin of the English Constitution, to understand first of all the real meaning of Magna Carta and the use which it makes of the fundamental contract idea of feudal law. 


\section{THE GERM OF THE CONSTITUTION}

familiar with feudal law. Underlying all of feudalism, practices, law and institutions, was the fact of contract. $^{19}$ The feudal relationship was created by a contract; it could be created in no other way. The fact that the terms of that contract were often, probably usually, unwritten is of no importance. Homage and fealty were the well-understood forms of making such a contract, and the custom of the locality defined clearly to both parties its terms, if no special variation from the ordinary in a given case required special definition. Now this fundamental contract of feudalism was everywhere regarded as contract always is: it bound both parties alike, not to quite the same things, but equally. It requires no long study of any feudal code to see that it all rests back on a contract, and a contract binding the sovereign as truly as the

${ }^{19}$ No one, I am sure, will suppose that in declaring Magna Carta to rest for its justification on the fundamental contract of feudalism, I am asserting that it was itself a contract between the nation and the king. Such an interpretation of the Charter appears to me wholly wrong. It assumes the existence in 1215 of a nation in the later sense, long before such a thing had come into being, and it assumes the existence of a political idea and theory even more impossible to the time. In saying that, as a statement of what the king is bound to do or not to do, it rests on the fundamental contract of feudalism, I am saying merely that it is a statement of feudal law. It was not Magna Carta but the circumstances of the future which gave to the fact that there was a body of law above the king creative power in English history. Magna Carta emphasized the fact and made the suggestion of the right of enforcement, in a way never forgotten, but this was all it did. Nor did feudal law furnish, except in a few particulars and these much transformed, the body of law by which the king was finally bound. The great work of Magna Carta was not done by its specific provisions; the secret of its influence is to be found in its underlying idea, the king must keep the law, and this it is which rests upon the feudal contract. 


\section{ORIGIN OF THE ENGLISH CONSTITUTION}

lowest vassal. ${ }^{20}$ So far as this principle relates to the ownership of land it is of no importance from our present point of view, for private property and royal grants must be to a degree secure in any régime. It was the peculiarity of the feudal system that it brought under the operation of this same principle public relationships and duties and nearly the whole body of public law. The vassal class, those who entered into the feudal relationship and who formed, while feudalism was at its height, practically the whole operative force of the state, bound themselves by the initial contract to certain public duties, financial, military, legislative and judicial, and to no more. We are here especially concerned with this fact from the suzerain's side. Of the services by which public business was carried on, he could demand of the individual vassal only those which the particular contract specified. The only point of vagueness in that contract was the obligation assumed by the vassal to serve his lord with honor and loyalty. There was nothing about this, however, which allowed the king to demand of the vassal without his consent further money payments than those specified, or more military service, or in different conditions of time or place, or to infringe his rights of private jurisdiction, or to subject him to a different mode of trial from the usual feudal, much less to punish him without ${ }^{20}$ On these points in regard to contract in feudalism, see note $\mathbf{C}$ at the end of the chapter (p. 203). 


\section{THE GERM OF THE CONSTITUTION}

trial no matter what he had done. In these particulars and others like them every feudal sovereign was a limited monarch, and the history of every feudal state gives evidence of the enforcement of these limitations against the king. This was just as true of the strong Norman kings as of any others, ${ }^{21}$ though they were the most powerful of all feudal sovereigns, and every reign up to Magna Carta shows the existence and effectiveness of these checks. ${ }^{22}$ Every one of them in some way recognized the fact that there was a body of law which he must observe. Particularly is this the meaning of the charter of Henry I. Like Magna Carta it contains very little that is new, but it rests on the fact that William Rufus had been doing things which he had no right to do, if we look at his action from the point of view of contemporary feudal law alone, and which the barons, therefore, had the right to bind his successor in terms not to do.

If now we turn to Magna Carta we find in the first place that the conditions which called it into existence were precisely of a sort to demand the enforce-

21 Plehn, Matheus Parisiensis, p. 1, notes this fact, but does not state quite accurately the reason for it. Glanvill, IX. 8, states clearly enough the general principles in regard to the limitations upon the lord's right of exaction. The passage refers directly to the mesne lord, but the same principles applied to the king.

22 Interesting instances of this fact in the case of the stronger kings are to be found in the failure of the demands of William II. regarding Anselm in the meeting of the curia regis at Rockingham in 1095, of the request of Henry II. for a change in the object of the "sheriff's aid" at Woodstock in 1163 and of the request of Richard I. for the feudal service in an unusual form at Oxford in 1197. 


\section{ORIGIN OF THE ENGLISH CONSTITUTION}

ment of this fundamental principle of feudalism. Looked at from the point of view of the feudal baron, John had been during the greater part of his reign frequently violating the feudal contract. To enumerate the particulars would be to name the larger part of the clauses of the Great Charter, ${ }^{23}$ but two particulars seem to have stood out to that time as especially wide-reaching in their consequences: John's financial methods and his disregard of judicial rights. Of course in neither of these respects was John an innovator; he was only following in the way opened by his father and brother. But circumstances had forced him to go forward in taxation farther than any one before him and, if this was not so true of the

23 Magna Carta does not state all the points of which the barons had earlier complained. It is discreetly silent on the subject of military service in France, for instance, which they had asserted the king wrongfully required. In this they were not right, and it is some evidence of the justice and exact legality of the Charter that it does not put forward such a claim. The "unknown charter of liberties," to be dated according to Mr. Prothero (E. H. R., 1894, pp. 117-121) most probably in January, 1215, contained a clause limiting service abroad to Normandy and Brittany. (E. H. R., 1893, p. 291 ; McKechnie, p. 569, c. 7.) The clause has the air of a compromise, and a natural one, since it names the two provinces in which many English barons would have immediate personal or family interests, and in which, or in the interests of which, their service abroad had been in earlier times usually rendered. The question at issue was not a simple one, because the ordinary feudal law was very apt to limit the area within which the military service of the vassal should be rendered on one side, and on the other the English practice and historical precedents were all against the demands of the barons. The subject was one in which a compromise might justly be in order, but if the clause in the "unknown charter" represents directly or indirectly some kind of a baronial demand, as it probally does, it was not insisted upon when the charter was drawn up in June, 1215. 
judicial system, the barons were now able to understand more clearly the result for themselves of the judicial changes, and also they might naturally connect with them, as showing their logical tendency, John's habit of arbitrary punishment without judicial process.

As we look at the issue between the barons and the king with our understanding of later times, our sympathies may perhaps be mixed. It is easy enough for us to see that $\mathbf{J}$ ohn was at work in the way of the future. The changes which he was striving to make were inevitable and necessary. The transformation which he was helping to carry through was the transformation of the medieval machinery of government into the modern. To this extent we may sympathize with him. But John was carrying forward this work decidedly under the influence of the tendency which seems to have been common in decaying feudalism, the tendency towards absolutism. If also we look at the matter strictly from the feudal point of view, it is impossible not to say that the barons were right. John's acts may have been steps towards a better future; but some of his methods of raising money he had no legal right to employ, the interference with private jurisdiction by the writ Præcipe was without justification, ${ }^{24}$ and the trial by their peers repeatedly 24 That is, without justification in feudal law. As already explained, in issuing the writ the king acted on his general right to make justice prevail, and to demand obedience to his writs. See Brunner, Schwurgerichte, p. 405; Flach, Origines de l'Ancienne France, III. 366, n. 5 . In 


\section{ORIGIN OF THE ENGLISH CONSTITUTION}

\section{demanded by victims of his tyranny, he could not}

justly refuse. In every particular touched upon in Magna Carta so far as it was a part of the old feudal law, the barons were wholly within their rights. ${ }^{25}$ They were stating law by which the king was already bound, as in his heart he must have admitted. ${ }^{26}$

But here was the practical problem. The barons knew well enough that legal right, as the law then stood, was on their side, but how was it to be enforced, how to be secured for the future against such a king?

other words he found his authority in an older ideal of his office which had survived in some particulars and which, wherever acted on in practice, was the source of inconsistencies and contradictions in the feudal world. In this case the fact should not be overlooked that the king used it to deprive his vassal of a property right, a source of income, which the feudal law affirmed to be his as truly as his domain manors. That the political system from which the right was drawn was not merely older but sounder and more permanent, has nothing to do with the case. By the system which was then ruling such matters and which had ruled them for generations, the act was unquestionably illegal. Though making a different application of the principle, Ralph de Glanvill stated it correctly in his decision in favor of the abbot of Abingdon when he is recorded to have said, nec dominum regem velle nec se audere contra consuetudines tam antiquas et justas aliquatenus venire aut circa eas aliquid immutare. Chron. Abingd., II. 298.

25 It will be noticed that some clauses, for example, clause 25, are not included under this statement.

26 As soon as he was able John denounced the Charter and procured its annulling by the pope. From the precedents established by his father and brother he was right enough in doing so, but to justify himself by a real and not a usurped right, he must fall back on that older conception of the kingly office, not recognized by the feudal law, to which I have referred in note 24 . In that conception of king and state, there was in truth no room for the principle on which the barons acted, but it was a conception which had had small share in the world, outside infrequent books of scholars, for more than two centuries. It may be said that the right to control the sovereign by force was merely an application of the general right of revolution which exists under any gorern- 


\section{THE GERM OF THE CONSTITUTION}

None of his predecessors had been stronger than he, none indeed had given such an exhibition of strength, had seemed so unshakable, or had held an unwilling nation in such a grip of iron. If defeat abroad and combination at home at last placed him at a disadvantage, how was the recovery of his tyranny to be prevented? How was the law to be made secure against his arbitrary will when the combination was broken up and his strength restored? This, the one urgent problem of the time, gives us the explanation of Magna Carta; how to deal with a king who persistently refused to obey the law which he was rightfully bound to obey and whose promises could not be trusted, how to deal with him in such form as not merely to secure incontestable recognition of the fact

ment, or that it was due in successive cases to the action of underlying economic and social causes whose operation may be stated in abstract terms. See my Civilization During the Middle Ages, p. 99, n. 1, and cf. Polit. Sc. Quart., XXI. 535. Such statements contain some degree of truth, and in the final narrative of human history they will be allowed due weight, but to the present-day work of the political historian they offer nothing of value. They are either equally true of all cases whatever their special form, or they deal with influences acting in so removed a degree, through secondary or tertiary agents, that they tell us nothing of what actually occurred, or of what the actors in erents believed. Nor do such generalizations ever take account of the external forms of the body of institutions, which condition to some extent, and in their forms record, adrance or decline. Whatever may be the business of the student of political science, or of the sociologist, it is the business of the historian, in the present stage of knowledge, not to deal with hidden causes, or with abstractions, but to find out what actually occurred and to describe as accurately as possible the immediately accompanying forms and ideas and the process of change. Nor personally do I believe that it is of value in any science to seek for ultimate causes until the phenomena are as accurately known as possible. 
that he was bound to obey the law, but also an accepted, legal and orderly means of forcing him to obey if he should break his promises. ${ }^{27}$

This is the explanation of Magna Carta so far as that is given by the historical situation which produced it. The written document gives us the same result. It was suggested of course by the charter of Henry I., and when the archbishop produced a copy of that charter its special fitness for the occasion must have been clearly seen. Once more, as by the earlier king, the law had been violated, and once more it was necessary to secure a pledge that those violations should cease. This gives us the body, the greater part, of the Charter. But in one point the case differed from that of Henry $I$. and in one point the Great Charter goes beyond the earlier one. The king from whom the pledge was demanded was the king who had violated the law. If the charter of Henry I. had been forced from William Rufus by insurgent barons, it probably would not have stopped where it did. Then, as in 1215, the difficult question would have forced itself forward how to compel the king to keep his pledge if he should again violate the

$2 \pi$ Examined from the point of riew of those who framed it, Magna Carta will be found to contain three great provisions or sets of provisions. First, no taxation of the feudal community without its consent, beyond the regular aids. Second, no modification or violation of the law by the arbitrary action of the king; and third, should the king be determined to free himself from the law, the right of forcing him to submit to it by civil war and if necessary by temporary deprivation of the royal power. In all these respects it exactly fits the case of John. 


\section{THE GERM OF THE CONSTITUTION}

law. To this question the barons of John found an answer where they found the right to proceed originally against the king, and to make the specific demands which they embodied in the Charter, that is, in the feudal law.

We should be led, I believe, to the same explanation of Magna Carta as a document, if we knew nothing of the charter of Henry I. The key to its meaning and to the right on which the barons founded it, is clause 61. Of that clause there are two questions to be asked: first, exactly what was it intended to do; and second, on what ground of right did it rest. In the first place, the general purpose of the clause lies plainly on the surface. It was to compel the king to keep the engagements he had entered into in the Charter. John had agreed to be bound by certain statements of law, mostly old, some new, embodied in the earlier clauses. In ordinary cases this would be enough. The king's promise in the form of a legal grant would be all that would be asked for. It is clear that John's promise was not trusted. The question how he could be forced to keep it would arise as soon as men began to consider the drawing up of a charter at all. It is possible that it was this question which led to the withdrawal of the northern barons, recorded by the Barnwell chronicler. ${ }^{28}$ Their spirit was such that they may very likely have said: it is utterly useless to try to bind the king with any 28 Walter of Coventry, II. 222. 


\section{ORIGIN OF THE ENGLISH CONSTITUTION}

sort of agreement; the experiment is not worth making. At any rate in the case of John the question of compelling him to keep his promise would be as immediate and pressing as any arising about the Charter. It is clear that in this difficulty the final appeal against the king would be to that which had originally forced the Charter from him-to insurrection. But obviously also this should be only a final appeal. The thing to be done was to devise some method of enforcing the provisions of the Charter, when the king proved unwilling, which would secure the rights granted, to which the king would agree, and which would involve insurrection only as a last resort. That is the specific object of the clause-to set up machinery which will take hold of abuses when the king refuses to reform them, enforce and protect the rights of the persons interested, and do so as recognized machinery of the state without a resort to force. It is this which gives it its institutional character and makes it the first in the line of experiments looking towards a constitutional limited monarchy.

The real nature and purpose of the clause is to be seen from the way it would have worked in practice. To four barons of the twenty-five, the individual was to bring his complaint of some wrong which he could not get corrected. Plainly then the four must decide whether the case was one of real abuse and one intended by the Charter to fall within their supervision. That is to say, the clause conferred upon them a judi- 
cial function, which was really a prerogative of the king's, to determine whether the law had been violated or not in a given case, and to grant redress. If the four found an abuse, they carried the case to the twenty-five, when of course their decision was subject to review. If the twenty-five, or a majority of them, agreed with the four, they called the attention of the king to the abuse and required him to redress it within forty days. This is all the king had to do with the case. He had no voice in the decision. His judicial prerogative of determining violations of the law and initiating their correction was taken away from him, and he was reduced to the function of executing the judgments of a court not his own. ${ }^{29}$ This was moreover under the sanction of civil war. If the king still refused redress the last resort was insurrection, which is declared legal, and defined as limited in character, and temporary only. Permanent deposition of the sovereign was carefully excluded. A clumsy arrangement, impossible to operate with success no doubt, but we should never forget that it was the first step ever taken in history towards what we know as a limited monarchy, towards the creation of a body of constitutional law which the king must obey under sanction of insurrection, and of machinery for its enforcement in such a way as to make insurrection only a last appeal. Considering that the men of 1215 had no ${ }^{29}$ The judicial function of the twenty-five barons is equally clear in clauses 52 and 55 of the Charter. 


\section{ORIGIN OF THE ENGLISH CONSTITUTION}

precedent to go upon, no model of any such machinery to follow, no literary expression of such ideas, no theorizing about such procedure, they did very well. The scheme was conceivably workable, practice would no doubt have disclosed fatal defects, but practice was exactly what nobody had as yet. The character of the scheme, however, is clear. It was a method which it was hoped would secure the enforcement of the Charter by putting into operation through others a function naturally belonging to the king but which he refused to exercise for the ends of justice, under the ultimate sanction of war. As I have said of the plan in general, it was not finally to be the way of the constitution. 'Transfer to others of the king's prerogatives, definite formulation of sanctions, legalization of insurrection, these were not to be in the end constitutional. But until Parliament had come into existence and had so far developed that it could begin to exercise in reality prerogatives to which it laid no claim in theory,. until it could begin the long process of transferring the real sovereignty of the state to itself, expedients of this kind were the only possible means of enforcing law and limitations upon the king, and it was in them that the constitutional monarchy had its origin.

Of the second question, on what ground of right did clause 61 rest, the answer is equally plain and has already been made. The clause rested on the same ground of right as the insurrection which had forced 


\section{THE GERM OF THE CONSTITUTION}

the Charter from the king. In the machinery of the court of twenty-five and in the modified and temporary right of insurrection which it recognized, the clause falls within the limits of the larger right. None of the insurgent barons would have admitted for a moment that he was guilty of treason, nor could the king, with due regard to the law, have proved him to be by the mere fact of insurrection. ${ }^{30}$ It would be

$30 \mathrm{On}$ the feudal right of insurrection and on other rights which the charter emphasizes, see Dodu, Histoire des Institutions Monarchiques dans le Royaume Latin de Jérusalem (1894), pp. 159-171. This book is an admirable introduction to the study of the Magna Carta. In some points of detail at least the feudal situation in England was more closely parallel to that in the Kingdom of Jerusalem than to that in France. Feudal law may be said, indeed, to have recognized with peculiar clearness the right of the vassal to make war on his suzerain when that suzerain was the lord paramount, because there was in that case no higher authority to which appeal could be made. It will be noticed also that deposition was the only form which the extreme penalty could take, which in the case of the mesne lord was confiscation, that is, the raising of the rear fief to be an immediate fief. See the references in The Political History of England, II. 439, n. 1. One of the most interesting statements of this right is that in the Etabl. de S. Louis (ed. Viollet), II. 75 (book I., c. LIII.), because it covers the duty of the rear vassal. The lord says to his liege man: "Come with me because I wish to make war on the king, my seignior, qui m'a ves le jugemant de sa cort." The man answers that he will go to the king and find out if the fact is as stated. If it is, he returns to his lord. Et se il ne s'an voloit aler o lui, il en perdroit son fié par droit. It will be noticed that the case supposed in the passage italicized above as calling the right into action is one of the chief grounds of complaint against John. The point with regard to treason, as a result in his case of the reverse process, the king's diffidatio of him, is clearly made in 1233 by Richard Marshal in argument with the king's representative. $M$. Par., III. 257-258, and cf. 274-275. See also the case of the earl of Albemarle in the annals of Dunstable, Ann. Mon., III. 64; the plea of Ganelon, Chanson de Roland, 348 (ed. Gautier), cited by Bigelow, Procedure, p. 287, n. 3; and Waitz, D. V. G., VI. 100, n. 3. The regularity of the diffidatio served upon him is at least tacitly admitted by John in receiving the homage of the barons after the Charter had 


\section{ORIGIN OF THE ENGLISH CONSTITUTION}

necessary for him to prove that there was no legal ground for the diffidatio which had been served upon him. There are indications which seem to imply that between 1210 and 1215 there was some feeling about in the minds of those who were preparing to oppose the king's tyranny for some legal ground of action against him. The theory of the old elective monarchy, which had been perhaps revived by the question of Arthur's title, seems to have been thought of. This probably accounts for the tradition about Archbishop Hubert's speech at the coronation of John, which Louis adapted to his own use in his manifesto of 1216, and which Matthew Paris recorded, probably more nearly in its original form. ${ }^{31}$ 'The coronation oath seems also to have suggested itself as a means of control, and this fact may possibly account for the form of oath which was demanded of John after the removal of the papal censures in 1213. ${ }^{32}$ But howbeen agreed to. See his writ which states that he had made peace with the barons at Runnymede, on Friday, June 19, ita quod eorum homagia eodem die ibidem cepimus, Rymer, I. 133. But however regular in feudal law the action of the barons may have been, the problem presented to them by the situation could not be solved by trusting to a series of individual diffidationes, nor even to what would be the most that could be hoped for under the law as it stood, a series of unconnected alliances among the barons formed to meet special cases as they arose. They desired permanent security, some means of holding the king steadily to the law. Such a state of things the law had not provided for, and could not; it could not consider the case of a king persistently unfaithful to his obligations. Hence arose the most original feature of the Charter, the commission of twenty-five barons.

31 Rymer, I. 140; M. Par., II. 454-455.

32 Roger of Wendover (ed. Coxe), III. 260, (ed. Hewlett), II. 81; II. Par., II. 550. 


\section{THE GERM OF THE CONSTITUTION}

ever it may have been with regard to such speculations, when the time for action came they were all fortunately dropped, and the baronage in insisting upon the king's feudal obligations fell back upon the natural and simpler feudal right of appeal, the diffidatio and its accompanying right of insurrection. This feudal principle accounts fully for the clause, and it is the only source from which its justification can have come. Had the barons acted on any other ground of right existing at the time, like election or the coronation oath, the clause must have taken another form.

The body of Magna Carta and clause 61 constitute together the first inclination of the constitution towards a limited monarchy and mark the point of time before which no tendency in that direction can be found, the one as insisting that there is a body of law which the king is bound to observe, the other as affirming that the community of the ruled has the right to set up machinery to enforce the king's obligation, and, if this proves insufficient, to levy war upon him. It is a beginning only, as yet incomplete. ${ }^{33}$ The body

33 The Charter itself, as has been said, determined nothing. All depended upon the interpretation and application which should be given it in the future, and if the opportunity to put it into form depended upon the accident of a king's character so also did its position in the future. Had a king like Henry II. or Edward I., or even like John, reigned in England during the fifty years which followed the death of John, Magna Carta might have made more difficult, but it would not have made impossible, the completion of the work which John had begun in the early years of his reign. Such a king might easily have thrown the Charter into the background, as did Henry I. in the case of his charter, have 
of law contains very little of that to which the king was subject in 1460 ; the machinery of enforcing it is less elaborate and perfected than that of 1258 or 1310; the method of protecting the constitution against the king is quite different from that of the seventeenth century. But it contains in germ all that followed; from it the whole constitution unfolded. Now this beginning is in the feudal system. Before 1215 in the history of English institutions, general as distinguished from local, lies nothing but the feudal system, modified only in the direction of a more absolute monarchy. The two fundamental principles of the constitution which Magna Carta declared were both fundamental principles of feu-

avoided any repetition or ratification of it, and have established a series of precedents of royal action without reference to the law which it would have been very difficult to overcome. The events of the months immediately following the granting of the Charter make this certain, and while the attempt to enforce the principles of Magna Carta by civil war and deposition before the death of John was of the greatest value as a precedent it was too inconclusive to determine the future. Of far greater value were the precedents established in the reign of Henry III., carrying the right of controlling the king by force far past the middle of this century of transition and making it a permanent element in the new conception of the state then forming in England. As a result, the machinery of royal prerogative action went on to develop as machinery for performing the details of government business, but its transformation into the basis of a constitutional absolutism was checked by the revival and permanent establishment of the feudal ideal of the relationship between lord and man, soon to be changed into that between sovereign and subject. In the extraordinary prerogative courts of the Tudor period, there was a revived possibility of a constitutional absolutism, but the Tudors did not press their advantage, such a result was probably never intended, and all possibility of it was destroyed in the next age. 
dalism and were drawn directly from it in 1215. The origin of the English limited monarchy is to be sought not in the primitive German state, nor in the idea of an elective monarchy or a coronation oath, nor in the survival of institutions of local freedom to exert increasing influence on the central government. Though all these were contributary, combined they could not alone have produced the result. The principle which moulds and shapes all elements into the great result came from feudalism. 


\section{ORIGIN OF THE ENGLISH CONSTITUTION}

\section{Note A. Ideal Feudalism in England}

$$
\text { (Page 149.) }
$$

Professor Maitland in his Constitutional History, pp. 161164 , argues that "that ideal feudalism of which we have spoken, an ideal which was pretty completely realized in France during the tenth, eleventh, and twelfth centuries, was never realized in England." He enumerates six "limitations which are set in this country to the development of what can properly be called a feudal system."

That peculiarities exist in the feudalism of England, as we see it in practical operation, it would be absurd to deny. That these peculiarities are due to limitations upon an ideal development of feudalism is also true, if we mean feudalism as popularly understood, the apotheosis of the local and individual, a nonnational, separatist feudalism. But if by feudalism we mean the institutional system proper, the customs and legal principles by which many private business relations were regulated, and nearly all public business was carried on from, let us say, the middle of the eleventh to the middle of the thirteenth century; and if by an ideal feudalism we mean a development of this system from the fundamental principles of feudalism to what these would logically imply, then it is by no means so certain that the peculiarities of Anglo-Norman feudalism are due to any limitations set to such a development. It would be more nearly, though not quite accurate to say that they are due instead to the very fact that the development is logical.

If we consider in detail the six instances named by Maitland as limitations on such an ideal development in England, what I have in mind may seem more clear.

1. "First and foremost, it never became law that there is no political bond between men save the bond of tenure." What is meant by this is the Norman reservation, in the rear vassal's oath to his lord, of fealty to the duke or king, and the statement is supported by a reference to the Salisbury oath in 1086. Such 


\section{THE GERM OF THE CONSTITUTION}

a reference must imply an interpretation of that requirement which I believe to be incorrect. There was nothing anti-feudal, or non-feudal, about the Salisbury oath, or the Norman requirement in general. What happened at Salisbury was only what is described more fully and clearly as the result in Scotland in 1175 of the treaty of Falaise by which the Scottish king became the vassal of Henry II. All the Scottish rear vassals were called upon at once to take the oath of fealty to their immediate suzerain's new overlord. See Gesta, I. 96. The requiring of this oath seems also to have been alleged by Henry II. as the reason of his call for the cartæ of 1166, Red Book of the Exchequer, pp. 412, 277. Cf. Esmein, Cours Elementaire, p. 193, n. 2 (1898), and c. 8 of the edict of Frederick I. of 1158, Mon. Germ. Hist., Leges, Sectio IV., Tom. I. $\left(4^{\circ}\right)$, p. 244, Libri Feudorum, II. 54 (55). The paramount duty of the rear vassal to the overlord, if he is in the right, is fundamental in feudalism, and if he is not in the right, even the immediate vassal's oath of fealty was in practice not binding. See Waitz, Verfassungsgeschichte, VI. 100, n. 3, and it was no more so regarded in England than anywhere else. It should be noticed that the passage cited in n. 30, p. 181, from the Établissements de Saint Louis clearly recognizes this duty of the rear vassal. English feudalism differed from that of most other countries in the fact that this obligation was expressed in the feudal forms in use, but it did not differ in the fundamental principles themselves. Wherever in practice the fealty of the rear vassal to his immediate suzerain excludes all obligation to his overlord, the fact is due to an exaggeration of local independence and is far from being an evidence of the logical development of the system as a whole. The Norman retention of the earlier more general practice (see, for example, Luchaire, Hist. Inst. Mon. (1891), II. 28) of the formal reservation of allegiance was no doubt at once a result of the greater power of the lord paramount and an element of it, but it cannot be adduced as evidence that Anglo-Norman feudalism was not "ideal." In the meaning given the term above, it was more truly ideal than the different practice found elsewhere. 


\section{ORIGIN OF THE ENGLISH CONSTITUTION}

2. "English law never recognizes that any man is bound to fight for his lord." This is a somewhat broader statement of one aspect of the first point, and the fact stated is to be accounted for in the same way. The emphasis in the paragraph is on the expression of such a duty in legal form, but I doubt if it can be found expressed as an unqualified duty in any law code which was in any sense general. See Libri Feudorum, II. c. 28. It certainly was not so expressed in the passage in French law referred to by Maitland-the passage cited in the last paragraph above, where it should, I think, belong, as bearing rather on the relation of the rear vassal to the overlord than on his duty to support his immediate lord in other quarrels. Surely in writing this paragraph Maitland overlooked Glanvill, IX. 1, 6, which comes as near to a statement of this duty as any that will easily be found, and which certainly does not refer to a conflict with an overlord. Whatever may be true of the law, Maitland recognizes that the facts in England come nearer to ideal feudalism, as he uses the term, than the law would imply. Still it must be admitted that in the relative frequency of private war, in local disintegration, and in the superior allegiance of the rear vassal to his immediate lord, Anglo-Norman feudalism differed more widely in surface appearance from the feudalism of France than in any other respects. If we think of feudalism as popularly understood, undoubtedly these differences make English feudalism seem to depart from a logical ideal. So much is this the case that it was the fashion a generation ago to account for the difference by supposing a conscious modification by William the Conqueror of ordinary feudal arrangements with the deliberate purpose of preventing the development in England of the sort of feudalism with which he was familiar on the continent. This interpretation of his acts is now generally abandoned. But it was beyond all question the unusual royal power and the constant high centralization (except in a reign like Stephen's) which prevented any results in England from that tendency to disintegration which seems entirely natural and logical when the natural relations between vassal and suzerain are disturbed $b y$ 


\section{THE GERM OF THE CONSTITUTION}

any weakness of the latter. Whether there was not in England so strong a royal power that this normal balance was disturbed to some extent in the opposite direction; whether there was not in some particulars less local independence than a logical feudalism would allow, I am not now prepared to say. If there was, I think that the disturbance was not great, the balance was far more evenly held than in most feudal countries; and that evidence of it is to be found not so much in military matters as in private jurisdictions. Serious interference with the local independence which a logical feudalism would allow was potential rather than real, I feel sure. In most matters it does not show itself in practice. It begins to be dangerous to feudalism proper with the changes of the reign of Henry II., and these changes led to a reassertion of feudalism which, so far as general principles are concerned, was permanently successful, and so far as details are concerned, temporarily. It could not be permanently successful in details because the social and economic forces which were undermining the feudal system were too strong to be held in check. As to military matters of which Maitland is chiefly speaking in this paragraph, I greatly doubt if the actual evidence sustains the general belief concerning the practical effect of the Norman reservation of allegiance. The test of such a political expedient would come when the mesne lord proposed to resist the king by force, and $I$ doubt if there was a baronial insurrection in Norman or Angevin England in which the rear vassals did not stand by their immediate lords in overwhelming majority. That certainly was the case in the rebellion of Richard Marshal in 1233 and in those against William II. and Henry I. at the beginning of their reigns. No insurrection could otherwise have been at all formidable. There are a number of interesting special instances the bearing of which has been generally overlooked. For example: Lanfranc's letter to William I. on the capture of Norwich castle in 1075 (Epist. 38, Opera. Ed. Giles, I. 57) shows clearly that the castle had been defended against the king's forces by vassals of Ralph Guader's, who had received lands in England, and implies that they obtained terms more easily and 


\section{ORIGIN OF THE ENGLISH CONSTITUTION}

better terms than those who were serving him for pay. In Henry I.'s great stroke for power at the beginning of his reign, in his attack on Robert of Bellême, he seems to have recognized in much the same way the rear vassal's duty of fealty to his lord. The garrison of Arundel castle was granted a truce to send word to Robert of their straits and to ask for assistance or permission to surrender, according to a not infrequent feudal custom. Robert eos a promissa fide, quia impos erat adjutorii, absolvit. Orderic Vitalis, IV. 170-171. Both Roger of Wendover and Matthew Paris (M. Par., III. 273-279) clearly regard the action of Geoffrey Marsh and other vassals of Richard Marshal's in Ireland in assisting in his overthrow as treason, especially detestable perhaps because of the manner of their action, but there is no word here or in any portion of the account of Richard's rebellion of any obligation of his vassals to the king. For an instance in Normandy in which Henry I., having captured the revolted Count Waleran of Meulan and some of his knights, punished rear vassals who had performed homage to him for their support of their lord, see Ord. Vital., IV. 459-461. Is there any instance in which a rear vassal holds himself bound to the king as against his immediate lord because of his reserved allegiance with what seems general approval? I do not at present know of any. I am disposed, however, to admit the possibility of some slight overemphasis of the suzerain's side of the feudal relationship before the reign of Henry II., and potentially at least of much after his reforms.

3. "Though the military tenures supply the king with an army, it never becomes law that those who are not bound by tenure need not fight." Nor did it in any feudal country or in any feudal barony. Military service by the non-feudal freeman was not common anywhere, perhaps more so in England than generally, but war was a matter of self-defense and, while the vassal was regarded as having a special duty to fight, his duty was never considered in law to exclude that of others. It should be remembered that military tenure was not necessary to the existence of the feudal relationship. On the military service of the non-feudal 


\section{THE GERM OF THE CONSTITUTION}

classes in general see the Revue Historique, XLIV. 313-327, and LXI. 144-145; Guilhiermoz, Noblesse, pp. 289-296; H. See, Seances de l'Academie, CLI. 519-520 (1899); Viollet, Établ. de St. Louis, I. 174; II. 93; III. 350; it is doubtful if Maitland would later have stated this as a peculiarity of England. See P. and M., I. 255-256. So far as the Assize of Arms is concerned, to which Maitland refers, the fact should not be overlooked that this measure was immediately imitated by Philip II. of France and by the count of Flanders. See Gesta, I. 270.

4. "Taxation is not feudalized," that is, taxation which is non-feudal does not permanently disappear. Some difference between England and other feudal countries in this respect did exist, due undoubtedly to the greater power of the sovereign. The fact should not be overlooked, however, that from the death of Henry I. to the reign of Richard there is no non-feudal taxation of any real importance. It was the new constitutional absolutism which Henry II. had created that was able to establish, or revive if one prefers that word, a non-feudal taxation which would have become an important feature of the new constitution if it had been allowed to develop uninfluenced by a feudal reaction. It should be noticed also that this non-feudal taxation does not in the least affect what may be called feudal taxation, does not modify it, or diminish it, or render it in any way different from that in other countries. Indeed feudal taxation in England was more logical and consistent than was generally the case, because the strong royal power maintained certain very characteristic feudal incidents, like the relief, which tended to disappear elsewhere because of the undue emphasis of the vassal side of the feudal relationship. Maitland's last sentence in this paragraph needs, I believe, some modification. It reads: "On the other hand, the king relying on the nation is strong enough to insist that the lords shall not tax their tenants without his consent." The reference here is, as I understand it, to the practice which is the subject of clause 15 of Magna Carta, and I would refer in general to the comment on that clause in chapter V. (p. 230). I do not think that any such limitation on the mesne 


\section{ORIGIN OF THE ENGLISH CONSTITUTION}

lord was established in law in the period here considered. What we find in the sources rather is such a principle in the course of establishment by what is really a royal usurpation. Book IX. of Glanvill, especially c. 8, 3 and 4, indicates clearly enough what was the actual law at that date.

5. "The administration of justice is never completely feudalized. The old local courts are kept alive, and are not feudal assemblies. The jurisdiction of the feudal courts is strictly limited; criminal jurisdiction they have none save by express royal grant, and the kings are on the whole chary of making such grants." This is very true. The independence of the old local courts did interfere with private jurisdiction as that is seen elsewhere, and in this feature the practical feudalism of England departs most widely, I think, from that of the continent. But I must maintain, however contrary to current opinion, that the extreme development of private jurisdiction, as it is seen in France for instance, is non-feudal. It is certainly not the realization of an ideal feudalism. No feudal principle calls for a transfer of public criminal jurisdiction to private hands. The break up of general government, the exaggeration of the independence of the vassal, the overemphasis of this side of things, were responsible for it and no logical development of feudalism itself. Feudal jurisdiction proper, that is, the jurisdiction of the lord's court over his vassals in their relations with him and with one another, was not interfered with by anything in English law or constitution until the new developments of the royal prerogative began. It is true, however, that it does not develop logically and normally. The atmosphere and the actual conditions were not favorable to it and, as I said, it is in this feature that English feudalism departs most widely from the ideal. But it is important to understand that the possession of a public criminal jurisdiction has nothing to do with the matter, except as practically the condition of society which would allow of an ideal development of feudal jurisdiction proper would very likely cause to drift into the baron's hands a public criminal jurisdiction also. But no baron anywhere possessed such a jurisdiction 


\section{THE GERM OF THE CONSTITUTION}

except by royal grant, or by derivation from an uncontrolled economic jurisdiction, which it must be remembered is nonfeudal in origin, or by bald usurpation.

6. "The curia regis, which is to become the commune concilium regni, never takes very definitely a feudal shape." With this I wholly disagree. The English curia regis was, I believe, from 1066 to the decline of feudal ideas in the thirteenth century as definitely and entirely feudal as any in Europe. The nonfeudal elements in it are to be explained as in chapter II. and not by any reference to the witan. They occur in every feudal state, and they constitute a defect in an ideal feudalism only because the existence together with a feudal organization of the state of a lord paramount who is at the same time a king necessarily involves some inconsistencies. There is nothing here that is peculiar to England. I think it not quite correct to say that the curia regis becomes the commune concilium regni. The coming into use of the latter name indicates no institutional change. The change is in ideas, in interpretation, though the new ideas are to lead by the close of the century to institutional changes.

No ideal feudalism is to be found in any country in actual operation, but when we use the term we ought to mean by it a feudalism which has developed logically all the essential principles of feudalism, not a part to the exclusion of others, to results which are ideally true to such an origin. The lord paramount as the head of the whole, and the binding together of all ranks in the feudal hierarchy by a series of reciprocal rights and obligations from the highest to the lowest, into a national organization by which a general government, which is real however crude, can be carried on, are absolutely essential features of the feudal system. They are indeed everywhere recognized in theory, though often widely departed from in practice. A feudalism which does not realize these features in objective fact as fully as it realizes the local independence of the vassal, which does not maintain both these sides, in modification one of the other, in normal and rational balance, cannot be an ideal feu- 


\section{ORIGIN OF THE ENGLISH CONSTITUTION}

dalism. It is in this sense that I say that in my opinion the England of 1215 was "the most perfectly logical feudal kingdom to be found in Christendom."

I am tempted to add that the Latin kingdom of Jerusalem seems to me to stand next in order in this respect, but this statement must be qualified by adding that the feudalism of the kingdom of Jerusalem is "ideal," so far as it can be called so at all, as expressed in its law and theory. As objectively expressed in practical operation, there were so many wide departures from the ideal that there would seem to be room to doubt how truly in some particulars the law as written down ever represented the actual facts.

\section{Note B. Feudal Legislation}

$$
\text { (Page 165.) }
$$

Evidence of the exercise of the legislative function either by the small or the large curia regis before the reign of Henry III. is not easy to find, but there can be no doubt that there was considerable action which may fairly be called legislation by one body or the other during the time when feudalism was at its height. It is not likely, however, that it was often the result of formal deliberation with a conscious purpose of legislation, as in modern times, or that it was usually embodied in anything approaching so near to the form of an enacted law as do the Assize of Clarendon and Richard I.'s Assize of Measures. Hoveden, IV. 33. On the legislative activity of William I. see P. and M., I. 88; Liebermann, Leis Willelme, Archiv für Neueren Sprachen, CVI. 136; Gesetze, I. 505, 2, $a$ and $e$. Few feudal enactments could have been, like many modern statutes, sources of wholly new law. They were rather regulations of procedure, to be followed by the courts or by administrative officers, or modifications made in existing customary law, or the settlement of difficult problems which had arisen in the work of the justices or of administrative officers. See Stubbs, I. 614. Hence it is easy to sce how closely such action of the curia regis would be 


\section{THE GERM OF THE CONSTITUTION}

related to its judicial action on one side and to its administrative on the other. Hence also it is likely that we shall find evidence of legislative action, not so much in formal enactments as in the shape of notifications, writs, and letters patent and close, and this even in cases so obviously direct legislation as the "ordinance" of William I. separating the spiritual and temporal courts. The function of legislation was also very closely allied to that of counsel and we may expect to find some evidence of it, as least in this related form, in charters, as in the two issued by Duke William before the Conquest in favour of the abbey of St. Evroul, in which perhaps the council went beyond its powers, unless its action was intended to be merely confirmatory, one dated in 1050 and the other it is likely somewhat earlier. Ord. Vit., V. 173-180; II. 39. From the names of the witnesses to these charters we may be very sure that the action was that of the small rather than the large curia, or at most of a reinforced small curia.

That these two forms of the curia, the large and the small, were in practice identical in all functions except the legislative, and that the choice between the two in any case depended merely upon convenience, or the importance of the case, I take to be so well understood as to need no illustration here. See Maitland, Memoranda de Parliamento, p. lxxxriii., and Bracton's $N$. B., pl. 1273. It would be of value if examples of legislative action, or what approaches near to it, by the small curia could be cited especially under such conditions as made it equivalent to a great council. Unfortunately they are very few. When we begin to look for evidence of the sort we at once find that it is difficult to determine in a given case whether a large or a small curia is acting. The sources do not distinguish between them and this is evidently due to the fact that contemporaries made in their own minds no distinction between them unless it be that of size. They use no other distinguishing words until differentiation of business has made considerable progress. If such a distinction was made we should look for it, I think, most confidently in such treatises as Glanvill and the Dialogus de Scac- 


\section{ORIGIN OF THE ENGLISH CONSTITUTION}

cario. But there is no hint that the writer of either book perceived any difference. Glanvill indicates clearly enough the existence of courts different in the circumstances and place of their meeting, and in their makeup, but all are called alike curia regis and no difference between them in jurisdiction or competence is suggested. Reference of a difficult question to king and council (Gesta, I. 207-208) does not imply a difference of jurisdiction, rather the contrary. So in the Dialogus, if a distinction in competence or function had been in mind it would almost certainly have been indicated, directly or indirectly, in I. c. 4 , where some progress towards a distribution of business is evident enough. By the time of Bracton great progress had been made in the differentiation of machinery and in the classification of business, and at least some progress had been made towards a definition of competence-as, for example, towards the development of a jurisdiction in error, P. and M., II. 668; Rymer, I. 320; Bracton, f. 108; the Provisions of Oxford, Stubbs, S. C., p. 391-but Bracton's "famous gloss" on c. 21 of Magna Carta shows in its form of expression-comites vero vel barones non sunt amerciandi nisi per pares suos et secundum modum delicti et hoc per barones de scaccario vel coram ipso rege, f. $116 \mathrm{~b}-$ that in this matter at least the various forms of the curia regis were still considered identical. See Dialogus, ed. Hughes, Crump, and Johnson, p. 67, and note. Glanvill and Bracton are chiefly concerned of course with the judicial activity of the curia, and the Dialogus with the administrative, but if no distinction was thought of as essential in these respects, it is hardly possible that any was considered to exist in the rarer and less conscious function of legislation. Howerer this may. be, it is certainly true that in the evidence itself of legislative action, so far as we have any, no such distinction is made between a large and small curia as to imply that contemporaries distinguished between them or to tell us clearly which was acting in a given case except by way of inference. In many cases inference does not enable us to decide with certainty between the two, even where we strongly suspect from the manner of the record that we have 


\section{THE GERM OF THE CONSTITUTION}

to do with one or the other. We can distinguish the two extremes easily enough. There is on one side the great council of the three set dates, meeting not on any fixed day, but almost always within two weeks after Christmas, Easter and Pentecost, and to these must be added those extra meetings to which all the tenantsin-chief were formally summoned. These are all clearly meetings of the great curia regis. At the other extreme is the body composed of the household and court officers only, or towards the close of the period the body composed of the specially appointed and sworn councillors of the king. Of the former of these forms of the smaller curia regis probably the best early examples will be found in references to the action of the Exchequer, especially when it is acting as something besides a mere administrative board, or in incidental evidence from the charters; of the latter form we have no evidence before the reign of Henry III., and perhaps not before towards the middle of the reign, our conclusion on this point depending very much on the view we take of the doubtful institutional situation during the minority. See Baldwin, The Beginnings of the King's Council, Trans. of the Royal Hist. Soc., N. S., XIX. 27-59. But the gap between these two extremes is filled by meetings of many intermediate grades too small for us to suppose that the entire baronage was summoned to be present, or in such circumstances that we are very sure it was not, and yet so large that it cannot be regarded as a meeting of any ordinary small curia regis, and by other meetings where the evidence leads us to infer directly that barons not usually attending the small curia were present. None of these can be called a meeting of the great council, strictly speaking; they are all meetings of a reinforced small curia, formed irregularly, upon no fixed principles, often it would seem almost or quite by accident. I say "reinforced" curia in order to use a wider term than "afforced," but one which will include this also. The latter term should mean a curia enlarged by deliberate intention, no doubt in many cases by a special summons issued to selected individuals. See a case in Bracton's $N . B ., \mathrm{pl}$. 1273. In strict feudal language the term "afforce" would seem 


\section{ORIGIN OF THE ENGLISH CONSTITUTION}

to mean the enlargement of a court by persons not regularly members of it, summoned for the occasion, often borrowed from another court. But gradations in numbers from a smaller to a larger are so numerous that it is clear that size had no significance in contemporary eyes as bearing on function. What does seem to have been considered of importance was the presence of certain individuals whose rank or influence would give weight to the action of the curia. So clearly does this seem to have been the case that when lists of names are given, I think we are justified in inferring that all persons of importance who were present are mentioned.

Among the rare cases of legislation, which seem not to have been the acts of a great council, which can be cited from the period before the accession of Henry III., particularly interesting is the case recorded in No. 10 of the Appendix to Robert of Torigni, Delisle, II. 241, Howlett IV. 333; Round, Calendar, No. 734, brought before an itinerant justice court in Normandy in 1155. While the action had no doubt all the effect of legislation, and is to be legitimately reckoned as an instance of feudal legislation (see Professor Powicke in E. H. R., XXII. 18, n. 15), it seems to have been reached in the way of a judicial decision. The statement of the facts and the use of the word diracionavit seem to imply this. It is, therefore, a good example of the close relationship of legislative and judicial action in the feudal age, as well as of the retention by the itinerant justices of other functions of the curia regis than the merely judicial, at least of their readiness to infringe upon them without hesitation. As a judicial decision, their action may have been based on some such principle of the old law as that stated in Leges Henrici, c. 55, Liebermann, Gesetze, I. 575. The case of legislation at Verneuil in 1177 , Gesta, I. 194, if we may judge from a combination of the season of the year with the names mentioned, seems rather to have been in a reinforced small curia than in the great council of Normandy. A case from Stephen's reign may be found in Delisle, Recueil des Actes de Henri II., I. 117, of legislation in enforcement of the truce of God adopted in the presence of the 


\section{THE GERM OF 'THE CONSTITUTION}

archbishop of Rouen and four Norman bishops et omnium baronum mearum subscriptorum communi consilio et assensu. The witnesses are the bishop of Carlisle and three barons. On the exchequer see Madox, I. 219-220. The legislation adopted to enforce c. 61 of Magna Carta, Rymer, I. 134 (27 June), can hardly have been that of a great council, but was undoubtedly decided upon in a reinforced small council. These, with the instance given from 1050, are the only cases I can cite at present before 1216. It is only after the accession of Henry III. that examples become more abundant and satisfactory. The action of January 30, 1230, Madox, II. 27, g, must, I think, have been that of a small curia, though the number of earls named is unusual. It may have been an especially large council, remaining in session after a meeting of the great council; that of February 11, 1232, is, I think, open to no question, Rymer, I. 202 ; nor is the action in regard to the preservation of the peace of June 1, 1233, Rymer, I. 209-210; nor that in regard to wrecks announced in a charter of May 26, 1236, if taken near that date, Ibid., p. 227. It is a little tempting to say that the records copied in Bracton's $N$. B., case 1117, show us a reinforced small council meeting and legislating in advance of a great council which also legislates upon another matter and then confirms the action of the smaller body. But exactly what took place in October, 1234, is not clear enough to enable us to affirm anything with certainty. Cf. Cal. Close Rolls, p. 588-589. It should be noted that October, especially October 13, was a frequent date for the meeting of a great council in Henry's reign. The legislation of the early weeks of 1237 raises some interesting questions. See Bracton's N. B., I. 106. The Annals of Burton, pp. 251-253, state that on February 5, legislation was adopted in regard to the forest officers of the king. Then follows immediately without explanation, as if a part of the same action of the council, the regulation in regard to the period of limitation for various writs which is usually given as c. 8 of the Statute of Merton, Statutes of the Realm, I. 1. Then follows, introduced by the words postea apud Kenentone coram ipso domino rege et 


\section{ORIGIN OF THE ENGLISH CONSTITUTION}

concilio suo, further legislation in regard to purveyance. The Annals of Burton are so trustworthy, particularly in the matter of documents, that we should naturally be inclined, in the absence of any difficulty in the account itself, to accept this statement of what was done by the council as it stands. But what was probably an entry on the coram rege roll of this year, copied into Bracton's Note Book (III. 230), says that the legislation in regard to writs was adopted in generali concilio apud Westmonasterium, and the notification of the change which was sent to the barons of Ireland (Cal. Pat. Rolls, 176), says it was provided before "E. Archbishop of Canterbury, the bishops, abbots, earls and barons of the realm of England," which would also naturally be taken to mean a general council. These two pieces of evidence together seem to be conclusive. A great council, apparently attended in unusual numbers, had been held at Westminster in January, at which a thirtieth had been granted the king in return for a confirmation of Magna Carta, and this confirmation had been made in the famous "small charter," dated January 28. M. Par., III. 380-384, Ann. Tewk., pp. 102-105. But the Charter, Patent and Close Rolls agree in placing the king at Kempton from February 4-10, the Patent Rolls from the second (Cal., p. 174), and the Close Rolls from the third (Cal., p. 520). It should be noted also that the formula in Burtoncoram domino rege et coram domino Edmundo Cantuariensi archiepiscopo et aliis terræ magnatibus de concilio domini regisfor the legislation of February 5, is more likely that of a small, or of a reinforced small, rather than of a great council, and that the legislation in regard to purveyance is put at Kempton. The great council probably dissolved on the granting of the charter (M. Par., III. 383), and the king proceeded to Kempton with a smaller number of barons. One of two conclusions seems necessary. Either Burton's order of events is wrong, and the legislation in regard to writs was adopted in the great council before it broke up-which seems to me the more probable, or this legislation adopted afterwards at Kempton by the smaller council was regarded as virtually the act of the larger by that 


\section{THE GERM OF THE CONSTITUTION}

identification of the two in other functions which does not close with the end of the century. Maitland, Mem. de Parl., pp. xxxvi. and lxxxviii. If the statement in Bracton's Note Book stood alone without that in the Patent Roll this would be the more probable explanation. In either case, it remains clear that the legislative function was exercised by what was not a great council of the whole kingdom. A number of other cases might be cited like that of May 9,1256, Statutes of the Realm, I. 7; Bracton's N. B., I. 42-43; and some of the cases cited in $\mathbf{P}$ and M., I. 180, n. 4. An interesting case of legislation in the exchequer is mentioned in M. Par., V. 588. Of this case it should be noted that the apparent emphasis on the ore proprio is not because of the king's action-the Rechtsgebot is just as necessary in legislation as in the judicial function-but because of the unusual fact of his actual presence in the exchequer. See cases of the same emphasis in other ways in Madox, I. $192 t$; II. 11, $z, a$. Other cases cited by Madox do not seem to me to the point. I do not think we can take cases of council and exchequer acting together, or the phrase coram rege, as indicating the personal presence of the king at any time in the reign of Henry III.

If any one prefers to call acts of legislation by the small curia ordinances, no objection can be offered, but if the term is used in order to distinguish them from legislative acts of the great council, a distinction is introduced into the twelfth and thirteenth centuries which did not exist until later. See P and M., I. $181 ; \mathrm{Mem}$. de Parl., li. ff. Whether a legislative act of the thirteenth century was finally to be reckoned as a statute or not depended apparently not at all on the body by which it was enacted, but on something of which we cannot be sure, on accident, or on the importance of the matter which it concerned, or on the question whether it remained for a considerable time the final legislation on the subject. The thirteenth century was busily occupied in differentiating official bodies, parts of the machinery, and in the classification of business, but not in the process which must logically follow of consciously differentiating functions, that is, of setting off different functions to different 


\section{ORIGIN OF THE ENGLISH CONSTITUTION}

bodies, or at least, it makes only the slightest beginnings in that direction. As the century goes on men are plainly beginning to think of the council officially in a way in which they had not thought of the old small curia. The councillor's oath shows that. But there is no change in function. The council in action is still the small curia, though we may detect beginnings of change like the greater emphasis which seems to be placed on the function of counsel, and the tendency to recognize in the council, as distinct from the new judicial system, a superior jurisdiction in error.

In regard to distinguishing names, and to what was said earlier in this note concerning a consciousness of a difference in size between the two forms of the curia, the frequent use of the terms magnum, or generale, with concilium, or placitum, in the chroniclers should not be overlooked. Documentary evidence is not so frequent-see Maitland, Mem. de Par., p. lxxxviii., n. 1 , but it is not wholly wanting. To mention a few cases only from the twelfth century, we have in generali consilio in 1127 in Cont. Flor. Wig., II. 90; magnum placitum in 1131 and 1132 in Henr. Hunt., 252-253, and cf. the habito non parvo conventu of Will. Malm., II. 534, for the former date; the in generalis concilii celebratione of 1136 , Madox, I. 13, $s$, is documentary; magnum concilium in 1164, Hoveden, I. 224; the same in 1170, Cont. Flor. Wig., II. 138; again in 1171, Gesta, I. 4, and in 1176, ibid., I. 107. For the reign of Henry III. the cases are too numerous to need citation, but the in generali concilio of Bracton's N. B., III. 230, cited above is documentary, and see Rymer, I. 152, and the magnum parliamentum of Ann. Tewk., p. 143, and the convenit ad parlamentum generalissimum regni Anglicani totalis nobilitas of M. Par., IV. 518, may be of interest. I have found no case of commune consilium before Magna Carta c. 12, and in this case of course the words may mean the common counsel, and not council, though they can equally well mean the latter so far as contemporary usage goes. While $I$ have never found a qualifying adjective to distinguish the small curia, I think there is evidence enough to warrant us in saying that the difference in 


\section{THE GERM OF THE CONSTITUTION}

size between the large and the small curia was noticed. Contemporaries in the thirteenth century undoubtedly made no distinction between the legislative. and judicial functions as exercised by the curia regis. The use of the word judicium for what is really legislation in the action taken by the council to enforce c. 61 of Magna Carta, cited above, is an interesting indication of failure to distinguish. In many cases also there was little practical difference as in the instance in Normandy in 1155. But this fact was not due to any positive identification of these two functions, nor to any conscious assignment of a double function to a single institution; it was wholly due to the fact that the men of the time did not think about their institutions or the processes of government at all. Later men did become conscious of these distinctions, and then, while in those institutions which may be said to be the old, unchanged curia regis, large and small, the House of Lords and the council, the same variety of functions continued, the exercise of these functions, the functions in exercise, were more and more sharply distinguished as time went on, except perhaps in an age of revolution like the seventeenth century, an age of revolution primarily in ideas and interpretation.

Evidence confirmatory of all the points of this note could be drawn from the contemporary sources of French institutional history.

\section{Note C. The Feudal Contract}

$$
\text { (Page 170.) }
$$

The reference to service is in the majority of cases indefinite, as per servitium militare, or merely pro suo servitio, or pro suo homagio et servitio. Any cartulary will furnish numerous examples. Homage appears to have been considered the really essential thing in the formation of the relationship. If the man was admitted to perform homage, fealty followed normally. The importance of homage as the formal recognition and acceptance by the lords of the rightful heir and of the rightful title to land 


\section{ORIGIN OF THE ENGLISH CONSTITUTION}

is clearly indicated in Glanvill, Book IX., especially c. 6. This was the meaning of homage performed to the heir to the throne during the lifetime of the father, to Matilda, daughter of Henry I., for instance, and of the acceptance of the homage of William, son of Henry I., for Normandy by Louis VI. in 1120; it was a binding engagement to recognize the right of succession when the time should come. Undoubtedly the provision of the law noted in Glanvill, IX. 4, 2-inserted in c. 3 of Magna Carta in the reissue of 1216 - that the homage of a minor heir must be received by the lord before he can exercise his right of wardship, refers to homage as a recognition of title. No clearer statement of the character of homage as creating a contract is to be found in the original literature of feudalism than that of Bracton, f. 78 b. (ed. Twiss., I. 620). Homage and fealty were usually so inseparable that it may almost be said that both were required to make the contract. Sometimes the contractual character appears clearly enough either in the oath of fealty or in the account of the homage. The oath of Henry II. to Louis VII. in December, 1158, reads thus: Ego rex Henricus assecurabo Regi Francorum sicut domino vitam suam et membra sua et terrenum honorem suam: si ipse mihi assecuraverit, sicut homini et fideli suo, vitam meam et membra mea, et terras meas quas mihi conventionavit de quibus homo suus sum .... [peace to be made with Count Theobald] . . . . Et postea si ei debeo aliquid servitii, faciam ei. Bouquet., XVI. 16. Cf. the homage of Robert of Gloucester to Stephen and its withdrawal: Wm. of Malm., II. 541, 545. Sometimes local custom is distinctly referred to as defining the service: Hæc omnia .... abbas reddidit ei et filio ejus Girberto in fœdio ita ut libere possideant et nullam diffinitam consuetudinem pro his omnibus reddant excepto illo communi et assueto servitio quod semper debet serviens hujusmodi seniori suo. Quoted by Flach, Origines, II. 556, n. 1, from a manuscript cartulary of Saint-Jean d'Angély; Et concedunt ... pro homagio et servitio suo per servitium militare sicut cætere milites de abbatia tenent, Ramsey Cartulary, I. 171, cf. 169. An instance of a similar method of definition affecting the 


\section{THE GERM OF THE CONSTITUTION}

duty of the lord is to be found in the Ramsey Cartulary, I. 154: dominus Walterus tenebit se cum abbate sicut cum suo homine. On these vague specifications of service see Waitz, Deutsche Verfassungsgeschichte, VI. 69-70. Charters mentioning specific services to be rendered are of course very numerous, especially where the payment of a money rent takes the place of all or a part of the service. Nearly all these cases, however, imply the ordinary feudal service, which is left unspecified, or vaguely specified, unless the contrary is indicated by some such phrase as pro omni servitio. See Chron. Mon. Abingdon, II. 132, 135, and the charter cited above from the Ramsey Cartulary, I. 154. A specification of services on the side of both lord and vassal is found in No. 76 of Vol. I. of the Antiq. Cart. Eccl. Baiocensis (Round, Cal., p. 530). For the use of homage as a means of making private contracts having nothing to do with feudalism, see the article on this subject by G. Platon, in the Revue Generale du Droit et de la Legislation et de la Jurisprudence, XXVI. (1902), in three numbers, pp. 1, 97 and 224. See also Imbart de la Tour on L'Evolution des Idees Sociales au Moyen Age du XI. au XIII. Siècle in the Comte Rendu de l'Acad. des Sciences Mor. et Polit., Tome 146 (1896), pp. 395-432 (reprinted in his Questions d'Histoire Sociale et Religieuse, 1907). M. Imbart de la Tour argues that the social revolution of the thirteenth century consisted in the extension of the régime of contract from the seigneurial class to the third estate. Cf. especially pp. 417-418. On the mutual character which is essential to a contract, I may cite: Mutua quidem debet esse dominii et homagii fidelitatis connexio, ita quod quantum homo debet ex homagio, tantum illi deget dominus ex dominio preter solam reverentiam, Glanvill, IX. 4, 1; et nota quod qua fidelitate tenetur vassallus domino, eadem tenatur dominus et vasallo, Durantis, Speculum Juris, title De Feudes, c. 2 (thirteenth century) in Homeyer, Sachsenspiegel, Bd. II. Qui solidus est de seniore, obtime debet ille servire vel secundum posse, vel secundum illorum conventionem; et senior debet eum habere contra cunctos et nullos contra eum. Usatici Barchinone, c. 36 (the oldest existing feudal code; this portion of it probably dating 


\section{ORIGIN OF THE ENGLISH CONSTITUTION}

before 1068) in Giraud, Droit Français au Moyen Age, II. 472, and cf. the constitution of Konrad II. of May 28, 1037, which formed the germ of the Lombard Libri Feudorum, especially the second paragraph. See also the notification by Philip II. in 1198 regarding the liege homage of Theobald, Count of Champagne, in Brussels, Usage des Fiefs, pp. 116-119 (Delisle, Catalogue des Actes de Philippe-Auguste, no. 533). This is so fundamental a matter in feudalism and has been so long almost a commonplace that proof is scarcely necessary. See Hallam, Middle Ages, chapter II., pt. I. As to the triumph of private over public law in feudalism, see as follows: Le régime feodal n'établissait entre les habitants d'un même pays aucune des relations qui nous semblent indispensables pour constituer un État. Il n'y avait alors ni impôt public, ni service militaire public, ni tribunaux publics. Seignobos in Lavisse et Rambard, Histoire Générale, II. 61 (Dow's Translation, p. 65), a rather extreme statement even if "pays" is taken in its narrow sense. One of the best brief descriptions to be found of the process by which the public law disappeared in the earlier feudal age and of its reappearance later is M. Pfister's in Lavisse's Histoire de France, II. 1. 425439. See also Flach, Origines de L'Ancienne France, I., Bk. II.; Revue Historique, XLIV. 347-348 (1890); LVI. 393 (1894); P. and M., I. 230-231, 526. The feudal contract not merely transformed a public duty into a private obligation, but, viewed from the side of the lord, into a property right. For a necessary modification of too extreme statements of the disappearance of public law, see p. 37 above. The definition of feudalism, that it is a system of things in which private law has usurped the place of public, is probably well known, but to me at least it does not seem that the bearings of this fact on English constitutional history have been seen as clearly as they should be, nor its consequences followed to the end. See Maitland, Constitutional History, p. 164, last sentence, which, I believe, is much too strongly stated. 


\section{CHAPTER V}

\section{Magna Carta ${ }^{1}$}

It is my belief that a clear understanding of what the Great Charter was thought to mean in the year 1215 by those who framed it and of its relation to earlier law and institutions, is indispensable to anyone who wishes to comprehend either how the English Constitution originated or what the influence of the charter was on later history. ${ }^{2}$ There is, I think, no institution and no set of facts bearing upon the establishment of constitutional government whose correct interpretation, as understood by contemporaries, is so vitally necessary as this. Such an opinion should go almost without saying because the Charter is a great generic or comprehensive document, gathering into itself in result almost all legal and institutional

1 The labor of anyone who comments in the future on the clauses of the Great Charter has been greatly lightened by the careful and learned work of Dr. W. S. McKechnie: Magna Carta, Glasgow, 1905. The book is far in advance of any earlier commentary in the application of a knowledge of medieval law and custom and of the results of recent investigations to the separate provisions of the Charter, and in the way of detailed explanation of most clauses it leaves little to be desired. In the general relation of the Charter to the body of feudal law and ideas of its time the book may be thought to fall somewhat short of what is needed, and this leads in a few cases to something less than a strictly logical application of feudal principles and to an occasional demand that the barons of 1215 should be influenced by political and constitutional notions possible only to the future.

2 See note $A$ at the end of the chapter (p. 252 ).

\section{[207 ]}




\section{ORIGIN OF THE ENGLISH CONSTITUTION}

history since the Conquest whatever may have been its influence upon the future. Certainly no apology is in place for so much of an analysis of the Charter as is required to find out its prevailing character, and the meaning of its more important provisions. It is not my intention in this chapter to go further than that.

If we put together the clauses of the Charter which are directly feudal in character we bring into one class clauses, $2-6 ; 8 ; 12-16 ; 21 ; 29 ; 34 ; 37 ; 39 ; 43 ; 46$; and to these we may add because of an important part of their meaning, $32 ; 53 ; 56 ; 60$ and 61 . With these really belong the following, growing directly out of feudal conditions: $1 ; 7 ; 26 ; 27 ; 41$; and 42 in one sense; $49 ; 58$; and 59 ; in all 32 out of the 63 clauses. If with these we put those other clauses relating to financial abuses, due in large part to the difficulties created for the government by the feudal régime, we add $9-11 ; 20-22 ; 25 ; 40$; and 55; making the total 40 . Due directly to John's tyranny and in large part to the means which he adopted to keep the feudal baronage under control are clauses $50-53 ; 56 ; 57$; and 62 . $44 ; 47$; and in part 48 refer to forest abuses, a most characteristic feature of the feudal age. 48 contains a provision for carrying out certain portions of the charter and 63 repeats the enacting clause with the necessary final clauses. Leaving eleven clauses unaccounted for. Of these eight, $17-19 ; 24 ; 36 ; 38 ; 45$; and 54 relate to the judicial system, and three, 28; 


\section{MAGNA CARTA}

30 ; and 31 to abuses of the king's powers of prerogative action.

This is a classification which is determined, I believe, by the meaning of the clauses taken singly and exhibits the character of the Charter as a whole. ${ }^{3}$ A slightly different one, but essentially the same, may be represented in tabular form as follows. In any scheme of classification that takes account of details certain clauses must appear, of course, from different points of view, or from relating to more than one subject, under two or more heads:

I. Initial and final clauses and the granting words: The Preamble, and clauses 1 and 63.

II. Purely feudal clauses or those containing legislative modifications of feudal abuses: $2-6 ; 8 ; 12-16 ; 21 ; 29 ; 32 ; 34 ; 37 ; 39 ; 43$; $46 ; 53 ; 56 ; 60 ; 61$.

III. Matters growing out of feudal conditions:

$$
1 ; 7 ; 26 ; 27 ; 41 ; 42 ; 49 ; 58 ; 59 \text {. }
$$

IV. Financial difficulties of government:

a. feudal : 2-6;

b. only indirectly feudal: $9-11 ; 20-22 ; 25$; $26 ; 27 ; 40 ; 55$.

V. Clauses unwarranted, or of doubtful right: $25 ; 27 ; 42 ; 45$.

3 See the classification of the clauses of the Charter by Professor Edward Jenks in the Independent Review, IV. 266, and cf. McKechnie, pp. 129144. 
VI. Clauses which wholly or in part may be called non-feudal: $23 ; 33 ; 35 ; 48$.

1. Judicial: $17-22 ; 24 ; 32 ; 34 ; 36 ; 38 ; 40$; $45 ; 54$.

2. The forest: $44 ; 47 ; 48$.

3. Prerogative: $28 ; 30$.

4. Due to John's tyranny: $50-52 ; 53 ; 55$; $56 ; 57 ; 62$.

\section{Clause 61 .}

That Magna Carta is essentially a document of feudal law, resting for its justification upon feudal principles, giving expression to feudal ideas, and pledging the king to a feudal interpretation of his rights of action in so far as they affected the interests of the barons, must, I think, be clear from this analysis, or from any careful study of its provisions. ${ }^{4}$ In justification of this view I propose to offer some comment upon the clauses of the charter, with no intention however, of including all the clauses, or of making an exhaustive commentary upon those selected.

4 That much the greater portion of feudal law as written elsewhere consists of limitations upon the vassal's right of action does not make Magna Carta really exceptional or indicate that it is not to be classed among the statements of feudal law. The formal feudal law, like every system of law, occupied itself with the protection of those rights most exposed to attack. In England, as we have already said, the extraordinary power of the sovereign compelled a careful scrutiny of his rights, an explicitness in their definition, and an emphasis of the illegality of other action which was not common elsewhere. In the field which more nearly corresponds with private law we have the same conditions as on the continent, and English land law is occupied mainly with limitations upon the rassal's action. 


\section{MAGNA CARTA}

Clause 1 is a concession to the church of its rights and liberties, freedom of election being specifically mentioned. Of this clause nothing need be said for our present purpose except to note that the necessity for it arose because of the incorporation of the church in the feudal constitution of the state, that is, because of the treatment of the prelate as a baron and of the endowment of his office as a fief. In defense of such an interpretation of the position of the church in the feudal age, there is much to be said, but the church could hardly accept this view of its public functions, ${ }^{5}$ and it had been struggling against it in England and elsewhere for more than a century. To the church the concession meant escape from those consequences of feudalism which were most serious to itself. Of the relation of the clause to the general situation which led to the Charter, it is to be said that on account of the importance to the barons of the alliance of the church, whatever the church demanded would in all probability have been included whether germain to the general body of the charter or not. As a matter of fact the concession is quite germain. It is away from a feudalism under strong royal control, and in the direction of sectional independence, in this case not of territorial but of political units.

The last part of the clause is strictly not a portion of it. It is the general formula of grant to the freemen of the kingdom of the points which follow in the 5 See Polit. Hist. Engl., II. 124-127. 
Charter. ${ }^{6}$ It is in the form of a complete and unreserved surrender of rights. Its effect, if used in case of a holding in land, as it frequently was, would be to cure all defects of title and to create in the grantee a perfect hereditary estate so far as the claims of the grantor and his heirs were concerned. The grant is "to all the freemen of our kingdom for us and our heirs forever, to be had and held to them and their heirs of us and our heirs." "There was no way known

f It is hardly the place here to consider in detail the diplomatic form of the Great Charter, but it should be noted that it is not possible to reason from its use of forms with any great confidence. It opens with the intitulation and address of a formal charter, and proceeds with the per consilium clause of a legislative act, though the description is hardly that usual to an ordinary great council. The effect of the per consilium phrase, as far as language goes, extends through the grant to the church but no further. Then follows a formal granting clause, rather in the form of a release than of a new conveyance (P. and M., II. 90). It almost looks as if this form of words were chosen because the possession, the seisin, by the barons of the rights to which they laid claim was now recognized, though it had been attacked by the king, but it would be impossible to assert that this was really intended. This grant covers all the charter which follows and is repeated in slightly different words in clause 63. There is then added an unusual clause about an oath sworn by both the barons and the king, more suitable to a treaty than to a charter. The final clauses which follow are those of a charter proper. The term "treaty" which has been sometimes applied to the Charter as a whole seems to me rery inappropriate, and the idea implied by it as to the crisis and its settlement quite inaccurate.

7 This conveyance is so unreserved and binding that, if the special privileges of Parliament claimed by the House of Commons in the "Protestation" of December 18, 1621, had been legitimately included among the detailed rights specifically granted in Magna Carta, there can be no doubt but that the words then used would have been fully justified: that the liberties, franchises, privileges, and jurisdictions of Parliament were the ancient and undoubted birthright and inheritance of the subjects of England. Taswell-Langmead, Const. Hist. of Engl. (6th ed., 1905), p. 419; Gardiner, History of England, IV. 261 (1883). 


\section{MAGNA CARTA}

to the barons of the time of making the concessions which they demanded legally more binding upon the king, or of putting him under a more secure pledge to regard them as law in his own conduct. Nothing is directly said or implied here as to whether the concessions were new law or old. If we insist upon the form of words, as we probably ought not to do, it would imply that they were old. So far as these words are concerned, they also imply a grant of the king's mere will as fully as the amended form used in 1225, but in the preamble they are preceded by the technical formula of legislation per consilium, so that it seems fair to suppose that this formula of grant was chosen not to emphasize any freedom of action on the part of the king, but to pledge him for the future by the most binding formula which they could select.

No question can arise as to the character of the five clauses following. They deal with the feudal incidents of relief, wardship, and the marriage of the heir. Clause 2 fixes the amount of relief to be paid upon a barony at one hundred pounds, and that upon a knight's fee at one hundred shillings. The language of the clause implies that this was the ancient legal relief, and by inference that the king in demanding larger sums before admitting the heir to his inheritance had been violating the law. So far as the simple knight's fee is concerned, it is possible that this was the case, but of the barony it cannot have been true, at least of any date later than 
William I. Certainly if it was true the proof is lacking, and the evidence against the contention seems clear. The author of the Dialogus de Scaccario says that the relief was called, both popularly and at the Exchequer, a fine, which certainly means that the amount was fixed by a bargain in each individual case between the king and the heir, the king getting all that he could, or taking less as an act of favour, and the author makes no distinction between the barony proper and the knight's fee, except when the knight's fee was held of an escheat. He implies rather that both the major and minor barony were treated alike in this respect. ${ }^{8}$ If we turn to the corresponding clause in the Articles of the Barons: art. 1, the language will be found significant. ${ }^{9}$ It is there said that ${ }^{8}$ See Dial. de Scacc., II. 10 and 24 (ed. Hughes, Crump, and Johnson), and notes, pp. 222-223; Glanvill, IX. 4, 4; McKechnie, p. 230, n. 2; P. and M., I. 308. McKechnie is, I think, right. The passage from the Dialogus makes it perfectly clear that in those baronies which the king holds as escheats the knight's fee pays only one hundred shillings. But it does not say, and does not imply, that this rule held of any knight's fee held in capite from the king, that is, ut de corona. If by the words major and minor baronies in the Dialogus, c. 10, the same distinction is meant as by the words in Magna Carta, clause 14, then it is clear that the relief of the knight's fee held in capite is not more fixed than that of the barony. The relief of a single knight's fee as recorded in the Pipe Rolls seems to be frequently one hundred shillings when held directly of the king. Of small holdings of more than one knight's fee there is no rule. It is, of course, possible that the fixed Norman reliefs had been the rule under William I., and that a part of the sin of William II. was to rencler the relief uncertain-to make it a fine-and this is incleed implied by the Charter of Henry 1., c. 2. Cf. Guilhiermoz, Noblesse, pp. 309-316. See P. and M., I. 312, n. 1, for high reliefs under Henry I. See a case of enforcement of this clause in the courts, Madox, II. $223 k$.

9 Stubbs, S. C., pp. 290-296. 
the heir is to have his inheritance per antiquum relevium exprimendum in carta as if they were not sure what the exact sum should be and were obliged to defer a definite statement until they could find out, or come to an agreement with the king.

While to this extent c. 2 is legislative in character, it would be difficult to show that in this demand the barons exceeded their just rights. An arbitrary relief, as large a sum as the king might be able to squeeze from the heir, is indeed entirely logical according to feudal principles. The vassal's right in the fief is completely at an end at his death. He has no right which he can transfer to any heir by testament or otherwise as an inheritance. The king's right of ownership intervenes as a real ownership between the vassal and his heir. This fact is recognized with peculiar distinctness in the English feudal law in the king's right of primer seisin. ${ }^{10}$ All this is a strictly logical deduction from the fundamental feudal relationship. But in spite of logic the right of the heir to succeed in the fief, the heredity of benefices,

$10 \mathrm{It}$ is interesting that nothing is said in Magna Carta directly or indirectly of primer seisin. Some evidence lingers in the later sources of feudalism, both French and English, which tends to the conclusion that this right was once possessed by every feudal lord. The feeling about the tenant-in-chief's right of inheritance is indicated by the saying about William II., that he would make himself every man's heir. The situation in the matter of inheritance, primer seisin, and relief in English feudal law is an instance of the logical derelopment of Anglo-Norman feudalism and of the fairly even balance between the rights of lord and vassal which resulted. 


\section{ORIGIN OF THE ENGLISH CONSTITUTION}

as a practical fact, had become firmly fixed throughout the feudal world and just as firmly in England as elsewhere. The rear vassal could bring suit against his immediate lord to enforce this right, ${ }^{11}$ and though exactly this could not be done by a tenant in capite, it would have been considered extreme injustice on the part of the king if the heir were permanently excluded from his inheritance without specific cause. In a large part of the feudal world, even the relief had disappeared, at the still further expense of logic, and certainly, judging by the feudalism of western Europe as a whole, the English baron was making no unjust demand in asking that the amount of his relief be fixed.

Of clauses 3, 4 and 5, relating to wardship, much the same is to be said as of clause 2. Whether the things demanded were sanctioned by ancient custom or not, they were clearly reasonable and not beyond the barons' legitimate rights. The last portion of clause 4 providing for the transfer of a ward's lands to the custody of two men of the fief itself when the appointed custodian is exacting more from the lands than he ought and so reducing their capital value, is new and therefore legislative. The provision is a fair one to which there could be no reasonable objection, but there is no evidence that it was ever put into force. $^{12}$

11 Glanvill, IX. 4-6 ; Bracton, f. $252 \mathrm{ff}$.

12 Bracton, f. 317 ; $T$. B., pl. 114t, 1201. 


\section{MAGNA CARTA}

Clause 7 in regard to a widow's dower and maritagium is only indirectly feudal in character and requires no comment. The abuse to which c. 8 refers, the extension of the right of marriage to the widow of a vassal and either putting her marriage up for sale or compelling her to purchase it herself, was one clearly not justified by the feudal law in general, nor by any logical extension of feudal principles, except in cases where she possessed an independent feudal holding of her own. That it was of long standing in England is shown by c. 4 of the coronation charter of Henry $I_{\text {., }}$ and it is possible that its origin is to be traced to the practice adopted, no doubt in many cases, at the Conquest in transferring the lands of Saxon lords to their Norman successors. There had been a similar extension of the right of marriage in England to male heirs, which the charter does not object to, but the change demanded by clause 8 is just from every point of view. Clauses 9,10 , and 11, relating to debts, while they indicate oppressive methods of the crown in looking after its financial interests, are non-feudal and may be passed over.

With clause 12 we come to one of the most famous of the clauses of the charter, one which has sometimes been called a constitutional clause and been supposed to affirm and secure the right of consent to taxation. What the clause does is to affirm the universal feudal right of consent to all extraordinary financial payments, to all not implied in the original contract by 


\section{ORIGIN OF THE ENGLISH CONSTITUTION}

which the relationship between lord and man was established. It would have been impossible to have gone further than this in 1215 . What we now understand by taxation was just beginning. The first steps towards it were taken in the last years of Henry II. ${ }^{13}$ Considerable progress was made in the reign of Richard I. and more by John, but neither the thing nor the idea of it was clearly enough in existence in 1215 to be made the subject of such a provision as this. Except for two particulars, to be noticed later, the clause states accurately the feudal principle. No financial exactions could be made by the king of his vassals without their consent, beyond those implied by the original contract, whatever might be the neces-

13 In the Saladin tithe of 1188, granted by the great council, and the first instance in England of such a grant to be paid by all classes of the population. Plehn., M. Par, p. 8. This is, however, to some extent an ecclesiastical tax, suggested by the older system of tithes, though the state took active part in granting and collecting it. It thus forms the transition from ecclesiastical to state taxation of personal property. See Cartellieri, Philipp II. August, II. 5-9, 14-18, 58-69. It is interesting that in the earlier action of January, 1188, at Le Mans, on which the English grant was based, a single assembly composed of barons of Normandy, Maine, Anjou, and Touraine, in which also, besides the king's son, Richard, count of Poitou, probably English barons were present, since the archbishop of Canterbury and the elect of Chester are named, granted the tithe for these separate feudal states. Gesta, II. 30. See also for like action in 1166, Gervase of Cant., I. 198. This beginning is continued in the reign of Richard I., in the taxes for his ransom in 1194 , and in the carucage of 1198 (cf. Stubbs, I. 539-540; 548-550; 627628 ), and under John, in the continuation of the personal property tax in 1203 and 1207, and in the annual collection of a scutage to 1207 . Stubbs, I. 561-562. These collections of scutage are to be regarded as steps towards modern taxation, though it is probable that modern taxes on landed property did not develop directly out of scutage. 


\section{MAGNA CARTA}

sities of king or state. And this was an entirely legitimate principle according to the feudal conception of things. I believe that our chief difficulties in thoroughly understanding the feudal régime proper-the feudal organization of the state-are occasioned by the fact that the fundamental relationship is one which, it naturally seems to us, should be economic, while in actual feudalism it was not economic at all, or only in the slightest degree, but was political. The economic tendency would be to say that feudalism is a form of renting land, and so it is, but when we examine it in practice we find that the rent was paid not in commodities, not in things of material value, but in political services, in the services which in the more common forms of society the freeman owes to the community as public duties. It was through these services almost solely, and if there had existed anywhere a state ideally true to the feudal type, it would have been in that case solely through these services, paid as rent for land, that the feudal state performed its functions, legislative, judicial and military, and in such a state the only revenue regularly provided in the feudal scheme would be the income of reliefs, of the specified aids, of wardships and marriages, and the chance of occasional escheat. ${ }^{1 *}$ These were implied as a part of the contract by which the vassal relationship was created, and they all find their explanation not in economic considerations but in the political ${ }^{14}$ See note B at the end of the chapter (p. 253). 


\section{ORIGIN OF THE ENGLISH CONSTITUTION}

ideas of feudalism. Anything more than these must be asked for by the king and received as a free gift, gratis as the feudal documents continually say, gracious aids as they came to be regularly called in France. $^{15}$

These points so far as they relate to feudalism, are no doubt familiar enough, but until a comparatively recent date no one has thought of applying them to the interpretation of clause 12. They furnish us, however, in truth our only means of interpretation. With the exception of the two points referred to above, the clause states nothing new. Neither the idea of taxation, of consent to taxation, nor of constitutional prin-

15 The distinction between economic and political feudalism is not so commonly recognized nor so clearly drawn as it should be. The main facts as to feudal payments with reference to c. 12 are more fully and more accurately stated by McKechnie than by any earlier writer, but they are not in all particulars critically and logically applied in the interpretation of the clause. See, for example, pp. 166, 169, n. 1, 173175. If we regard Magna Carta as a document of 1215, there is no ground on which certain of its clauses can be distinguished from the others and called constitutional. "The clause expunged from the charter seems practically to have fixed the law," P. and M., I. 350. Stubbs, I. 621. The passage just cited from P. and M., I. 350, probably refers to c. 15. Neither the insertion nor the omission of c. 12 or of c. 15 , changed the law in any particular so far as consent is concerned. See $A$. H.R., V. 649 , n. 1 (1900). The statement of Stubbs, II., Sec. 220, as to the rights secured by the commune concilium before the end of the reign of John, mentions nothing except the ordinary feudal rights of the great curia in all contemporary states. For a statement closely parallel for the kingdom of Jerusalem, see Dodu, Inst. Mon. du Royaume de Jér., pp. 162-164. The clause beginning ne tailage in the passage on escheators in the Provisions of Oxford (Stubbs, S. C., p. 391), is not a reminiscence of c. 12 , but is based on c. 5 , or on this and c. 43 , both of which survived in the charter of 1225. See Bémont, Simon de Montfort, p. 120, n. 2; M. Par., VI. 353. 


\section{MAGNA CARTA}

ciples in themselves, is to be found in the clause. It simply states what was already the universal law of the feudal world, and beyond this world with the ideas proper to it, it was not possible for the barons to go. Within it the barons were demanding of the king in this clause nothing except an honest and fair regard for the ordinary obligations of the feudal contract.

Of two particulars, as has been said, the statements just made are hardly true and, if we may judge by the treatment of the clause in the reissues of the Charter, one of these particulars was the real reason of its existence, and in the eyes of the barons its only important portion. This is the provision in regard to scutage. $^{16}$ Scutage is here treated exactly like an "aid," but as a matter of fact it rested upon an entirely

16 The clause regarding scutage, c. 8 , in the "unknown charter of liber'ties" (see $E . H . R ., 1893$, p. 291 , and 1894, p. 121), is open to far less objection on these grounds than the clause finally inserted in the Great Charter. If the date of the "unknown charter" is January, 1215, and the clause on scutage was deliberately changed when the Articles of the Barons were drawn up, it was a change for the worse. The language of the "unknown charter" is: Et si scutagium evenerit in terra, una marca argenti capietur de feodi militis, et si gravamen exercitus contigerit, amplius caperetur consilio baronum regni. McKechnie, p. 570. It would be entirely competent to the barons to agree with the king that scutage when taken should be at a certain rate, and that when need to increase it arose the increase should be made by the great council. The rate for ordinary scutages was fixed, however, by the clause quite too low and very likely this was the reason for changing the statement. In this clause of the "unknown charter" consilio very clearly means counsel. If the purpose of the barons in c. 12 was merely that they might be able in the future to fix the rate at which a scutage should be levied, they should have said so plainly. It is very possible that they meant no more than this. Clause 44 of the reissue of 1217 


\section{ORIGIN OF THE ENGLISH CONSTITU'TION}

different basis. An aid beyond the three specified, is an out and out free gift, an addition by agreement to any services which the lord could demand; scutage is a payment in commutation of a service which was due under the original contract. In strict law the king had the right to insist upon the service and to refuse to take money in its place, but also the vassal had an equal right to insist upon the service and to decline the king's offer to accept a payment in its place. ${ }^{17}$ A proposed scutage, therefore, gave rise to a right of consent of one kind on the vassal's part which undoubtedly accounts for the mention of scutages and aids together in this clause, but it is quite a different right from that of consent to an aid. It would be quite proper for the great council to declare a certain occasion a suitable one for the payment of an aid to the king and such a declaration would have properly the same effect upon all tenants-in-chief alike, but such a declaration by the great council in regard to a scutage could have in strict law and in justice no common effect. The individual vassal would still be entirely within his rights in insisting that he can very easily be interpreted as meaning a demand to return to the rate at which scutages were levied under Henry II. It should be noticed that we have one account of the action of a great council in such a case. Wendover says (in M. Par., II. 484), that on January 2, 1204, convenerunt ad colloquium apud Oxoniam rex et magnates Angliæ; ubi concessa sunt regi auxilia militaria de quolibet scuto scilicet duæ marcæ et dimidia. Cf. Ann. St. Edmundi, in Liebermann, Anglo-Normanische Geschichtsquellen, p. 143. The Pipe Roll shows the scutage to have been collected at this adranced rate (Mitchell as in note 20 ).

17 See the comment on clause 29 below.

[222 ] 


\section{MAGNA CARTA}

alone should determine whether in his circumstances payment or service would be preferable. To this extent the barons were clearly going beyond their legal right in the provision concerning scutage, not merely with regard to the king but with regard to the members of their own body.

How far considerations of this sort influenced the later treatment of clause $\mathbf{1 2}$ it is impossible to state. We can go no farther than to say that the insertion in the original charter of the clause, with its elaboration in clauses 13 and 14, shows that the matter was regarded as one of importance. But all these provisions go by the board after 1215 with only the statement in 1216 that it with some other doubtful matters-dubitabilia -had been omitted for future consideration and in 1217 that scutage is to be treated as in the time of Henry II. We can add that verbal changes in the charter of 1215 as compared with the Articles of the Barons, and those in the reissues of 1216 and 1217 , seem to be generally in the direction of a more careful accuracy both in the definition of legal rights and in the statement of exactly what is meant. ${ }^{18}$ There is certainly some ground for thinking that the barons may have been conscious that in their statement about scutage in clause $\mathbf{1 2}$ they had gone farther than they were justified in going and that, therefore, as scutage was the main reason for the clause the whole subject was omitted in 1216 , with a 18 See note $\mathrm{C}$ at the end of the chapter (p. 256).

[223] 


\section{ORIGIN OF THE ENGLISH CONSTITUTION}

general reference to dubitabilia, because no satisfactory substitute could be thought of in the hurried conditions of the moment, and later, still troubled by the difficulty of accurate statement, they contented themselves with the historical reference to the time of Henry II., which did really state vaguely but accurately what they wanted.

The insertion of this clause, and the evident importance placed upon it would seem to indicate clearly that in the opinion of the barons changes had been made in the methods of taking scutage since the time of Henry II., which were contrary to law and justice. So far as we can tell from the knowledge of facts which we now have, these changes had been made: the rate had been raised from the usual twenty shillings to two marks, once in 1204 to two and one-half marks, and once in 1214 to three marks, and with the exception of 1200, scutages were taken every year from the accession of John in 1199 to and including $1206,{ }^{19}$ in 1210 , two at two marks each in 1211 , and in 1214. In all these cases there was some pretence of a campaign in the field for which the military service of the tenants-in-chief was due. "In 1202 and 1203 no copy of a general summons exists, but it is probable that one was issued. In 1204 the host was summoned but not despatched, yet a scutage was taken. In 19 In regard to the temporary cessation of scutages in 1206 , it should be noticed that, at least after the interdict, the revenue of the state from ecclesiastical baronies taken in hand must have very greatly increased. 
1205 only a body of picked knights was sent and a scutage was taken." It would seem as if the most of which the barons could complain was the weight of the taxation-the increase of the rate and the frequency of the levy-with possibly some stretching of the rights of the king to determine the occasion. There certainly seems some tendency on the part of John to use scutage as a modern state uses an annual tax on real estate. ${ }^{20}$

The second particular in which clause 12 departs from the commonplace is in the provision with regard to the aids of the city of London. As this portion of the clause gives rise to some interesting questions not bearing directly upon the main subject of this chapter, I refer the reader for a discussion of its interpretation to Appendix III. at the end of the volume. It will be there seen, I think, that whatever we may conclude its meaning to be, it is based wholly on feudal ideas. Out of this portion of clause 12 directly grows clause 13. A comparison of these two portions of the charter with article 32 of the Articles of the Barons gives evidence, as is shown in other cases in note $\mathrm{C}$ at the end of the chapter, of the comparative carefulness with which the Great Charter was drawn up. To clause 13 as it stands there could be no possible objection from any source.

${ }^{20}$ From Dr. S. K. Mitchell's work on Taxation in the Reigns of John and Henry III., New Haven, 1914, to which I am indebted on several points. 
Clause 14 is another of the clauses of the charter which have been called constitutional and it has been supposed to stand in intimate relation with the creation of Parliament and to secure to the nation its representative system. Nothing could be further from the facts. The idea of the later Parliament was quite impossible to the time and, if it could have been explained to the barons in $\mathbf{1 2 1 5}$, it probably would have been rejected, and very likely with indignation. Feudal ideas in England had declined in strength in some particulars since the middle of the twelfth century, but that decline had not yet gone far enough, nor become general enough to admit even in thought of the possibility of the introduction into the great council, the typical feudal assembly, of a whole class not merely non-feudal but even servile according to current notions. If we omit the words which follow et sic facta, then the clause contains nothing new and makes no change of any sort. ${ }^{21}$ It simply says that

21 It seems unnecessary to argue that the first part of this clause produced no change of any kind, either in the method of the summons or in the persons to whom it was sent. See McKechnie, pp. 293-297. The distinction in the form of summons was probably a very old one. See Flach, Origines, III. 442. The summons to the council merely followed usage in other matters. The distinction in the form of summons for military service is well known. See the writ of William I. to the abbot of Evesham printed by Round, Feud. Engl., p. 304, which he dates 1072. See the difference in the payment of relief in Domesday, I. 280 (Vinogradoff, Society in the Eleventh Cent., p. 308, n. 2). I doubt if the case of the summons of Thomas Becket to Northampton in 1164 (Materials, III. 51, II. 391), can be cited, as by Stubbs, I. 608, approved by Round, Peerage and Pedigree, I. 355, as evidence of the "double system of summons," for I think the archbishop was not summoned on that occa- 
by common council in c. 12 was meant the ordinary general assembly of feudal tenants-in-chief, summoned in the usual way. It is barely possible that the phrase in regard to the statement in the writ of the object of the summons may have been intended to require a more specific notice when an extraordinary aid was to be asked for than was usual, but this is not a necessary interpretation and apart from this certainly no change was made and the clause was quite uncalled for. There is nothing corresponding to it in the Articles of the Barons, and if it had been left out of the charter the whole procedure would have been exactly the same, assuming that consent by the great council was intended by c. 12. It is quite possible that the reason for the introduction of the clause

sion by the sheriff to be a member of the council, but to appear before it in its judicial capacity ad instiantiam prædicti Johannis pro eadem causa (Polit. Hist. of England, II. 285), or rather for a slightly different case growing out of that. The passage quoted from the Materials, III. 67 , in note 4 of chapter II., would seem to imply that barones secundae dignitatis were not usually summoned to a meeting of the great council at that time. As to when and where the line was drawn between the major and minor barons, in either military or court service, seminary work on the available material in two different years, in connexion with other topics, leads me to feel sure that, if the statement in P. and M., I. 280, "We shall probably be nearer the truth if, in accordance with later writers, we regard the distinction as one that is gradually introduced by practice, and one that has no precise theory behind it," is to be modified at all, it must be in the direction of a more unqualified statement that there was no fixed line. As to when such a line was drawn, I think it always existed from the beginning of feudalism and was never consciously established. As to how it was drawn, while there may have been in mind somewhat vague principles to be followed, I feel sure that their application varied greatly both on different occasions or on the same occasion as to different individuals 
is to be found in its closing phrase. This provides that the business shall proceed upon the day appointed according to the counsel of those present although not all those summoned may have come. Such a provision can hardly mean anything but that the decision of the council will be held binding upon all, or that it will have the same degree of force upon the absentees as if they had been present. This has the air of being something new, and if we consider it to refer to a grant of extraordinary aids only, or to scutage, it probably was new. According to strict feudal right the individual baron would have an absolute veto in such a case so far as his own payment was concerned. The new principle would be, however, an easy and natural derivation from the legislative right of the great council. Beyond question clauses 8-11 of the Assize of Clarendon must have been binding on all

who are to all appearance alike. If we may judge from the returns from the Norman inquest of c. 1172, where the distinction seems to be made, Red Book, II. before and after p. 632 , it would seem to be based on no principles at all. It should be noticed that the Assize of Northampton, c. 7, and the justice commission of 1194, c. 18, seem to preserve the right of holders of quite small tenures to go direct to the curia regis with their cases. It seems to me highly probable that both before and after 1215 cases are numerous in which no minor barons at all were summoned to the great council. I think the clause made no difference in this respect. Nor do I think it can be called reactionary in any sense (McKechnie, p. 298). As to the binding of the absent by the action of those who are present the case is more doubtful. It would hardly seem that this explicit provision could have been thought necessary if the principle were already accepted, and yet besides the cases of legislation referred to in the text, a tax like the Saladin titne must have been binding on all. Cf. Gesta, I. 91; Stubbs, I. 607; II. Sec. 222; Viollet, Inst. Polit. France, II. 193, and below note 22. 
barons, whether they were present when the Assize was adopted or not, and clause 12 certainly contemplates no more serious interference with feudal rights than those provisions. Legislation even of the crudest type would not be possible unless this were so. If the object of clause $\mathbf{1 2}$ was to bring about a new method of determining when a scutage should be paid, then the inference from the legislative right of the council would be not merely natural but essential to the carrying out of the plan. In that case the concluding words of clause 14 indicate that the barons were not unconscious of the difficulty created by the provision regarding scutage in clause 12. The point, however, is one that cannot be insisted upon because we have no evidence as to what the earlier practice was. As to the later practice, it would seem that with the omission of this clause from the reissues of the Charter, this provision fell to the ground for a considerable time at least. ${ }^{22}$

${ }^{22}$ If this feudal principle of individual consent is pushed to its logical conclusion then the provision of c. 12 that an extraordinary aid should be legalized by consent of the common council was new, legislative in character and of doubtful propriety. I do not feel sure what should be said on the matter, though probably in strict feudal law individual consent was necessary. If so, c. 12 was legislative, so far forth, and the part of c. 14, relating to the binding of the absent by the decision of the council would be an addition to the law, properly made if sanctioned by the consent of both barons and king, but beyond the competence of the great council to insist upon as a right. As a matter of actual practice such a position would probably have seemed, even in 1215, too great a refinement of technical law, and it seems likely that the great council had already gone so far in many cases as to declare a given occasion a proper one for the payment to the king of some 


\section{ORIGIN OF THE ENGLISH CONSTITUTION}

Clause 15 has been regarded as one of the clauses of the Charter in which the barons secured for their tenants or were forced to secure at their own expense, the same concessions which they demanded for themselves. I think that this may have been the case, but it must not be overlooked that there was probably no tenant-in-chief of the king who was not also a rear vassal, very likely many times over, holding scattered pieces of lands and even manors from his fellow tenants-in-chief. ${ }^{23}$ There would surely be few of the barons who secured the Charter who would not have an immediate personal interest in checking any abuses aimed at in clause 15. It is also true that no baron could possibly object to this provision unless he proposed to make extraordinary exactions unjustly. In one way c. 15 may be made to give evidence of the strong control under which Anglo-Norman feudalism had been held by the king. It seems natural to infer from its wording, though it is not directly stated, that a royal license was considered necessary before a baron could take an aid from his own tenants, and that in some cases King John at least had granted such licenses for the collection of extraordinary aids which the tenants had then been forced to pay with

extraordinary aid, at a specified rate, including the new lery on personal property, leaving the individual payment to the individual baron though under a practical compulsion. There is a discussion of the practice under Henry III. as to binding the absent by the action of the council in Mitchell as referred to in note 20.

23 See the case of the earl of Oxford in the court of Broughton, Maitland, Man. Courts, pp. 48-85. 
no other authorization. This may very likely be true, but if so it was a royal usurpation with no justification in feudal law. ${ }^{24}$ Strictly interpreted, the relation between a rear vassal and his immediate lord, so far as it relates to aids, was one of the lord's property rights with which the king had nothing to do. The lord would be quite within his rights in taking an aid without any license from the king and no royal license could give him any right to take an extraordinary aid without the consent of his tenants. Whatever John may have done, at least the later practice is in conformity with the feudal idea, for what the king does is not to grant the right to take an aid but to request the tenants themselves to grant one to their lord. The cases which seem exceptions in form are so infrequent comparatively that it is very improbable that they were real exceptions. Such a request

24 Glanvill, IX. 8, shows clearly enough that no writ was necessary in his time even for distraint. An actual case of 1182 is recorded in the chronicle of Jocelin de Brakelond (ed. Camden Soc.), p. 20. But see Très. Anc. Cout., XLVIII. 2. The regular principle is finely stated in the following notification of the Count du Perche of 1214: Ad universorum notitiam volumus pervenire, quod milites nostri de castellaria Bellimensi talliam de feodis suis et hominibus suis nobis debent tantummodo feodaliter, pro his quatuor rebus quæ sequntur: Pro prima militia nostra; pro prima captione nostra de guerra; pro militia filii nostri primogeniti viventis; et pro prima filia nostra maritanda. Præter has tallias, nec a militum feodis, nec ab eorum hominibus, tallias possumus feodaliter extorquere. Et ne hujusmodi libertas ab aliquo heredum nostrorum in posterum infringatur, eam sigilli caractere fecimus communiri. Brussel, Usage des Fiefs, p. 414, from Martène, $A m p l$. Coll., I. 1117. The aids mentioned are really only three, since the lord would take an aid for his own knighting only when he had not been knighted in the lifetime of his father, on the same principle as the aid 
from the king may have had in many cases the practical effect of a command, but so long as the writ went no farther than this, there is no objection which could be made to it according to the letter of the law.

Clause 16 is a statement in simple language, from the vassal's point of view exclusively but quite correctly, of the fundamental feudal idea, the contract between the man and his lord. It is a statement in general terms of the principle which underlies such a specific regulation as that of clause 12 , and indeed of nearly the whole charter, and it would be impossible for John to find any ground on which to object to its insertion in the charter. It implies, of course, that the king had been exacting in the past more service than he was entitled to, but there is no evidence of any kind to connect it with the barons' objection to service in France.

Clauses $7-22$ and clause 24 relate to the operation of the new royal judicial system as distinguished from

for the marriage of a sister. See p. 253, n. B. The principle of the king's writ, even when it has the form of a command is undoubtedly indicated by the following to the tenants of the Constable of Chester, Pat. Rolls, $5 \mathrm{John}, \mathrm{m}$. 1. Mandamus vobis firmiter præcipientes quatinus efficax auxilium faciatis eidem constabulario domino vestro ad redemptionem suam. Ita quod inde vobis grates scire debeamus. From Madox, I. 615, $y$. "That these are only letters of request" (Madox, I. 617), in reality could be shown from numerous cases on the rolls of Henry III. See the cancelled writ- in favour of the earl of Pembroke, Cal. Pat. Rolls, 1234, p. 57. The principle is stated by the king in 1237 in the grant to the free men of Hovedensire. Ibid., p. 190, and it comes out clearly enough in the well-known case of Hugh Tracey-Bracton's $N$. B., pl. 1146-where the lord has the king's writ to take one of the aids, but it is granted to him by his men. 
the older system of feudal and local courts. They show that on the whole the barons were satisfied with it, and willing to allow it to go on. There is no doubt something of an inconsistency, as has already been noticed, between their attitude in these clauses and that disclosed in clause 34. The scheme of recognitions provided for in clause 18 could not be carried out without a suspension of the baron's liberty and an interference with his court of much the same kind as that effected in a different way by the writ Præcipe. ${ }^{25}$ It was, however, a less direct interference, the advantages to be derived from these recognitions were obvious, and very likely the barons did not perceive how logically the various portions of the royal system of justice hung together, nor the full seriousness of the attack upon themselves. One abuse of a financial sort these clauses do forbid, the practice of the royal courts of amercing an offender not accord-

25 It is interesting that Bracton, and the courts of Henry III. were able to argue that a writ of cosinage, though a Præcipe quod reddat, was not a violation of Magna Carta, c. 34, because it had the effect of an assize of mort d'ancestor only, that is, it raised only the question of seisin, leaving the real question of title still to be tried under a writ of right. Bracton, f. 281 ; Bracton's N. B., pl. 1215. To a baron of Henry II.'s day who understood fully the bearing of the new royal justice upon his baronial jurisdiction, if such a one existed, this would have seemed an extraordinary defense of a writ which really took the case out of his court. For he would see that though the trial of the question of title must be begun in his court, it could be begun there, if we are correctly told, only by the king's writ and that the process thus begun would almost inevitably carry the case out of his court again before there could be any real trial of the issue. See P. and M., I. 587. It is to be remembered, however, that, so far as we can tell, there was never any decided opposition to this side of the new procedure. 


\section{ORIGIN OF THE ENGLISH CONSTITUTION}

ing to the heinousness of his crime but according to his ability to pay, and whatever may have been the attitude of the barons towards the jury in some of its uses ${ }^{26}$ they were ready to sanction its employment in the Assizes and in fixing the amount of an amercement, asserting, however, expressly in clause 21 that this sanctioning of the jury was not to affect the regular feudal right of the baron to be judged by his peers. Clause 24 undoubtedly makes a step in the development of the professional justice, but how rapidly that development was going on the baron could not yet fully understand, nor what it would mean in the end for the feudal conception of his position in the state as the operative force by which business was carried on. For the present his interest was in the great development of the idea of the king's pleas which had recently taken place and in the new methods of trying them. It is altogether probable that he would prefer that these new methods, with their suspension of his privileges, should be put into force by regularly appointed king's justices, than by sheriffs, who might be his neighbors or inferiors, or by more subordinate officers still, especially if the royal pleas were to be tried, as was not infrequently the case, before the king's representative sitting in the baron's court. Clause 17 refers to the body of

26 The use of the jury prorided for in c. 20 is very near to its primitive use in early Carolingian times. Action by a jury is also required in c. 48. 


\section{MAGNA CARTA}

justices appointed by Henry II. in $\mathbf{1 1 7 8}$ to be always attendant upon his court for the trial of cases as a kind of permanent itinerant justice court, as has been described. The result of the clause, as is well known, was finally to fix their sessions at Westminster-an important step in the development of a professional Common Pleas Court. Clause 17 also indirectly approves of the existence of this court, if we may now call it a court for convenience, but clause 18 goes on to say that it shall no longer have power to try the three assizes, possibly because it no longer goes about as the king does from county to county, but that they shall be tried in the counties in which they arise by justices on circuit. In a sense clause 18 necessitates clause 21 because it fixes in the new royal courts the trial of civil cases in which the barons would be interested as parties. To this, as has been said, they apparently did not object, but when it came to amercements, a matter having some of the same consequences that a criminal trial might have, their feeling was different. That must be referred to their peers. In this sense clause 21 is supplementary to clause 39, providing for the same thing in civil cases that it probably does in criminal. ${ }^{2 \pi}$ While this group of clauses refers primarily to the new royal justices, traces are not wanting of the feudal ideas and feudal

27 This interpretation receires support from the royal mandate of 121819 to the itinerant justices in Kent cited from Madox, I. 529, 0, in note $\mathrm{D}$ at the end of the chapter on c. 39. 
sensitiveness of the barons. Clause 21 may also be interpreted as an afterthought to clause 20 , and as such it is an addition to the Articles of the Barons. Clause 20 makes a division of those interested in the itinerant justice court into three classes. The aliorum of clause $\mathbf{2 2}$ shows that the distinction was consciously made. It looks very much as if it occurred to those who were framing the Charter, after they had put clause 20 in shape, that by its language earls and barons, naturally included in the term liberi homines, would be subjected to amercement in the king's court by the probi homines de visneto. To avoid this clause 21 was added. The reasoning was carried a step further for the benefit of the other liberi homines in 1216.

Clause 23 relates to abuses in the enforcement of the ancient obligation of trinoda necessitas, probably due to an attempt in a small way to relieve the financial difficulties of the crown. In clause 25 we reach the first of the few clauses of the charter in which the barons exceeded their rights and forced a concession from the king unjust in itself and to which they could show no title. Revenue from the sources, other than the manors, which went to make up the county ferm, had increased undoubtedly from similar economic causes to those which had increased the revenues from the domain manors. From every point of view the king was entitled to his full share of this increase, especially as these same economic changes affected 
expenses as well as revenue, and were in considerable part the cause of the financial difficulties which pressed so heavily upon John. The interest of the sheriff and of the baronial class from which the sheriffs were chosen, in maintaining the old ferm unchanged is obvious, but the demand was certainly unfair and it was abandoned in the reissues and disregarded during the reign of Henry III. ${ }^{28}$

Clauses 26 and 27 relate to the treatment of the personal property of free tenants deceased and have for their object to protect their heirs against exactions of the crown in collecting debts due it, and in

${ }^{28}$ See McKechnie, pp. $372 \mathrm{ff}$; G. J. Turner, Royal Hist. Soc. N. S., XVIII. $289 \mathrm{ff}$. The incrementum, or crementum, appears in Domesday (I. $64 \mathrm{~b}$; I. 154 b. Ballard, Domesday Inquest, p. 75). It is of constant occurrence in the reigns of Henry II. and Richard, and from the beginning of John's. See for example, the Pipe Roll of 22 Henry II., 16, 48, 60; 23 Henry II., 26, 107, 124. Madox cites many cases from the Pipe Rolls of all three kings. See I. 202, 329, 330; II. 138, 139, 225, 226. An interesting case of the increment of manors is cited by Madox, I. 192, from the Pipe Roll of 6 John. John had, however, from 1205 on demanded in certain cases an extra payment, the proficuum, above the "ancient incrementum." If it was this to which the barons referred in c. 25, they should have made their meaning clear, for the two are plainly distinguished in the Pipe Rolls of John (Mitchell). Even if the proficuum only was referred to, the clause was still unjust to the king because the contemporary price revolution had undoubtedly already increased the returns from the counties as well as from the manors. Of the financial revolution in general much evidence might be cited. See Chron. de Joc. de Brakelonda (Camden Soc.), pp. 56-57. Compare note $x$ with note $z$, Madox, II. 152; in the Pipe Roll of Richard I. the pay of a knight is given as one shilling per day, William Salt Arch. Soc., II. 54; in 1258, it is four shillings, Maitland, Man. Courts, p. 62. John may, however, very likely have set his demands too high. In 1205, the proficuum paid by twelve sheriffs amounted to 2000 marks (Mitchell). 


\section{ORIGIN OF THE ENGLISH CONSTITUTION}

the claim laid to the chattels of those dying intestate. While it may be that the demand in these clauses is fair and just, clause 27 at least was legislative in character and was omitted in the later issues of the charter. The clauses are feudal in character only as to the origin of the claims which the crown had been enforcing. Clauses 28, 30, 31, relate to the prerogative action of the king of the nature of purveyance in taking private property for public uses. Such action was naturally the occasion of many abuses and whether fair or not in any given case would almost invariably give rise to disputes and ill feeling. It was, however, a right so rooted in the past and so necessary under the financial conditions created by feudalism that the feudal law itself, which ordinarily had no place for prerogative action, generally recognized it in these cases in some form or other as the right of all suzerains. The Charter does not attempt to do away with this right but to do away with abuses under it, but these were so inveterate that they remained for centuries subjects of just complaint.

Clause 29 in regard to the feudal right of castle guard is very interesting because in it the barons stated clearly and with perfect accuracy the fundamental principle of scutage which they had disregarded in clause 12. No knight was to be compelled to give money for this service when he was ready to perform it in person or by a suitable substitute if there was a reasonable cause for not doing it himself. 
Both the occasion which would give rise to the abuse complained of and the principle laid down for correct action apply exactly to the case of scutage and some among the barons would undoubtedly recognize the fact as soon as they gave careful attention to the subject. Clause 29 is wholly feudal in character and in it the barons were entirely within their right.

Clause 34 is the one clause of Magna Carta which reveals indisputably a reactionary tendency. Others, like clause 39 in which such a tendency may be seen, have other possible interpretations, but there is no ambiguity about clause 34. It is directed plainly against one feature of the new royal justice and is an unqualified prohibition of its further operation. ${ }^{29}$ For an account of the action of the writ Præcipe, and

29 The new writs and complicated procedure which were invented to aroid the prohibition in c. 34, illustrate in one direction the profound influence of Magna Carta. For there can be no doubt but that the prerogative system of justice was so well established by the middle of the reign of Henry III., so generally regarded by clients as well as lawyers as practically the only method of bringing litigation regarding land to a conclusion, that all objection to the writ Præcipe in its original form would have disappeared and procedure would have developed in a much simpler form, if it had not been for the clause in the charter. See McKechnie, p. 412; P. and M., I. 172; Bracton's N. B., I. 135. Cf. Bracton's N. B., pl. 1328, with Madox, I. 793, d. Similar questions regarding the boundary line between king's courts and baronial courts arose in France with the development of royal justice. See the following from an ordinance of 1302: Hoc perpetuo prohibemus edicto, ne subditi, seu justiciables prælatorum aut baronum nostrorum aut aliorum subjectorum nostrorum trahantur in causam coram nostris officialibus, nec eorum causæ, nisi in casu ressorti in nostris curiis audiantur, vel in alio casu ad nos pertinenti. Ord. des Rois, I. 36\%. Cited by Hallam, Middle Ages, chapter II., pt. II., Am. ed. I. 241. Cf. Étab. de St. Louis, II. c. xxxii., ed. Viollet, II. 441. 


\section{ORIGIN OF THE ENGLISH CONSTITUTION}

the grounds of the barons' objection to it, reference should be made to the discussion of the subject in chapter II. If the question is raised why the barons should have undertaken to decree this particular writ out of existence, while they said nothing directly about the writ of right, and expressly approved of the continuance of the assizes, both of which had the same effect upon their courts, it would be difficult to make a satisfactory answer. It hardly seems sufficient to say that the writ Præcipe was a more blunt and undisguised attack upon their judicial independence, being based only upon a somewhat transparent right of the king's to ask why they had disobeyed an order which in the circumstances must inevitably be disobeyed, as he must have known when he issued it. This is, I think, however, all that can be said in explanation. If clause 34 stood alone it would be a slender foundation upon which to argue a reactionary tendency in the Charter as a whole, but its unmistakable revelation of the baronial feeling makes it a strong support to a similar interpretation of other less plain provisions.

Clause 37 clearly recognizes the right of the king to the wardship of all the lands of a minor heir of whomsoever held if the heir was for any portion of his holdings a tenant-in-chief of the king by military service. This was a right of the sovereign clearly recognized by Norman practice though it is to be classed with such rights as the marriage of a male 
heir, or of a widow, as extensions of ordinary feudal law in the interest of the lord paramount. None of these practices, which had become established in English law, whether they are to be justified on feudal principles strictly applied or not, did the barons make any attempt to abolish. The distinction between grand and petty serjeanties is hardly one of kind and is of no great importance; the tenure is a frequent one, was very convenient, and is distinctly feudal, a tenure of service, though not ordinarily reckoned as a military tenure, strictly speaking, not paying scutage. It should logically give rise to feudal wardship. $^{30}$ It was only to the abuse, to a usurpation of the king's in asserting this right when he had no feudal claim, or to lands not feudal in character, that they objected, and in this they were right. Wardship of this kind was a feudal right only and could be exercised only upon feudal grounds. The clause seems

30 On the law before 1215 see Glanvill, VII. 10, 2; Très. Anc. Cout., XI. 3. Cases of the operation of this clause in respect to serjeanty tenures were not numerous because it would not often happen that one held a fief of the king by a grand serjeanty tenure without at the same time holding others by military tenure so that the right of prerogative wardship would come into operation in the case of his minor heir, leaving the serjeanty out of account, but there are cases enough to show that the right was exercised in case of grand serjeanty tenures. See Madox, I. 326, $l, m$., and the cases cited in P. and M., I. 323, n. 4, from Bracton's N. B., pl. 743, 1183, 1231, 1270, 1280; Cal. Close Rolls, 1232, p. 34; Cal. Pat. Rolls, 1252, p. 143 . Bracton, f. 37 (Twiss, I. 292, c. 9), calls a serjeanty tenure military but he is not thinking of the technical distinction between them. Elsewhere he distinguishes between them, f. $87 \mathrm{~b}$. On scutage from serjeanty holdings, see Madox, I. 650. On the general subject, see Round, The King's Serjeants and Officers of State (1911). 


\section{ORIGIN OF THE ENGLISH CONSTITUTION}

to imply that the right referred was allowed in case of a grand serjeanty tenure, as it certainly was later, and that the claim to exercise it had even been made in the case of petty serjeanties. The barons showed in this a greater moderation than those who framed the charter of Henry I., or the difference may perhaps be explained by the fact that these rights, doubtful at the beginning of the twelfth century, were now looked upon without question as fully established.

Clause 39 has always been regarded as one of the most important clauses of the Charter and this judgment is probably correct whether we regard its provisions taken by themselves, or think chiefly of the light which the clause may be made to throw upon the general intentions of the barons and the purpose of the Charter as a whole. The conclusions which we ought to draw from it, however, depend upon the establishment of its exact meaning and as this can be done, if it is possible to do it at all, only by a somewhat minute analysis, it has seemed best to relegate that portion of the discussion to the notes and to deal here with the conclusions only. ${ }^{31}$ If the interpretation which that discussion indicates as on the whole the more probable is accepted, viz., that what the barons had in mind in this clause was not chiefly the form of trial, but was the general body of the law and the rights which it secured them, then the provision is to be regarded as reactionary in only a slight 31 See note $D$ at the end of the chapter (p. 262).

[242] 
degree..$^{32}$ It uses words which can be later interpreted as securing a judicium parium to the baronial class, but this particular point was not in mind in 1215; what was then demanded was a trial according to law and securing to them their legal rights. Taken in this sense clause 39 of Magna Carta would correspond somewhat closely to the general prohibition included in Amendment XIV. to the Constitution of the United States: "nor shall any State deprive any person of life, liberty, or property without due process of law." The clause is, I think we must say, strictly feudal in character; the barons had in mind almost certainly no one but their own order, and the court which they demanded was the king's feudal court. From such a narrowly feudal point of view, ignoring the king's new prerogative courts, they were entirely right in the demand they made. Under the feudal law, alone considered, there was no way by which the king could rightfully deprive them of their property, or personal liberty, or life, without a judicium parium. The rather vague and general terms in which they stated their demand, while they give us labour in interpretation, proved historically fortunate, because, as men's legal ideas changed and feudalism disappeared, they could be adapted to new conceptions of civil rights and seemed in the end to embody a universal

32 That this clause was reactionary in tendency was, I think, first suggested by Gneist. See his History of the English Constitution (translation), p. 294, n. 2 (1891). The preface of the original is dated 1882.

[243 ] 


\section{ORIGIN OF THE ENGLISH CONSTITUTION}

principle of political liberty. There is a sense in which it is not wrong to say that this broader protection was secured to us by Magna Carta, and also to say the same of the other rights once erroneously supposed to be directly intended by the Charter, like the jury trial, Habeas Corpus, and consent to taxation. What did secure them to us was in truth the steady development of the limited monarchy and constitutional government which dates from Magna Carta and without it could hardly have been. In this sense it would not be incorrect to say that the sentence quoted above from the Constitution of the United States is a modern formulation of clause 39 .

Of clause 42 it must be said that it deprived the king of one of his prerogative rights exercised long before and long after this date. ${ }^{33}$ The clause was legislative in character, securing to the barons a privilege which they could not demand as a right, and it properly disappeared from the first reissue of 1216 and was not restored at any later time. Clause 43 is plainly feudal but its provisions are so clear as to require no comment. It was old law and entirely just. ${ }^{34}$ Nor do

33 See the incident under William I. recorded in Orderic Vitalis, III. 248 , where the ground of right for the king's action in such casesdeprivation of service-is stated. Cf. Liebermann, Quadripartitus, Bk. II. Pref. 2; Gesetze, I. 542. The reference in Stubbs, I. 576, n. 7, to the charter of April 5, 1200, should be from Magna Carta, c. 41, not from c. 42. For Henry III., see M. Par., III. 248.

${ }_{34}$ Dial. de Scacc., II. 24. It seems to me unlikely that c. 12 of the Petition of the Barons of 1258 (Stubbs, S. C., p. 384), relates directly to the point of this clause. I think it refers rather to the grant of an entire 
the clauses relating to the forests, $44,47,48$, call for special notice here. While not directly feudal they concern a most characteristic feature of the feudal age destined to decline with the decline of feudal society. The use of the jury in clause 48 as a means of carrying out several provisions of the Charter should not be overlooked. Clause 45 refers to an undoubted abuse, but the barons would have found it hard to justify their right to make such a demand from the principles on which they were acting in the main body of the Charter. For once the formulation in the Articles of the Barons, clause 42, requiring a positive promise from the king seems preferable to the negative prohibition of the Charter ${ }^{35}$ Clause 46 utters a complaint of the tenants-in-chief somewhat general throughout the feudal world. What is asked for rests upon the commonly recognized principle that the foundation of an abbey carr ied with it the rights of the advocatus. This is one of the features of feudalism, however, which the developing royal power seems everywhere disposed to attack and generally with success. The barons were quite within their rights in the clause but the position was one

escheat by the king, like the grants so frequent from the "lands of the Normans," for which the claimant afterwards appears.

35 Louis IX. in the Mise of Amiens decided against the right of the barons to deprive the king in the Provisions of Oxford of his power to appoint whom he would to the great offices of state, but c. 45 was dropped from the reissues and it was consequently not a part of the Charter which he declared to be binding upon Henry III. 


\section{ORIGIN OF THE ENGLISH CONSTITUTION}

practically very difficult to defend. ${ }^{36}$ Clauses 49 to 53 and 54 to 59 , are of temporary interest relating to specific acts to be performed by John in undoing his tyranny or to questions arising about the immediate application of some provisions of the charter. Nothing need here be said about them.

Upon clause 60 a good deal too much emphasis has been placed as showing the spirit of the barons in forcing the charter from the king and their attitude towards other classes. McKechnie is quite right in his comment on the clause. I would only suggest in modification that it could hardly have applied to all freeholders, but only to feudal sub-tenants. With such an interpretation the clause to a considerable extent reveals contemporary ideas about the Charter as a whole. If the Charter is in the main a restatement of feudal law, clause 60 follows as a matter of course. If the barons insist that as suzerain the king is bound by the principles which they lay down, they must admit that they themselves as suzerains are bound in the same way. Otherwise the law they are invoking would not be feudal law. If the insertion of this clause was called for by the king, as on the whole seems hardly likely, the barons would have no ${ }^{36}$ As to c. 46, Valin maintains-Le Duc de Normandie et sa Court, pp. 85-88-in opposition to Luchaire, Manuel, 286, and Brussel, Usage des Fiefs, p. 810, that the rule here stated to bind the king in the future was the rule in Normandy. The facts do not seem to be as yet entirely established. Cf. the case recorded in the Cartulary of Mont-SaintMichel, Chron. Stephen, Henry II. and Richard, IV. 340, No. 35 (Round, Cal., No. 73r). 
ground on which they could refuse. If the Charter of Henry I. was in any way a model for Magna Carta, the similar provision in clauses 2 and 4 of that document may have suggested this clause. Strictly speaking the clause was unnecessary; it would have been law without the statement here, but as a matter of fact the barons in this particular seem to have held themselves no more bound by the Charter than the king. ${ }^{37}$ The addition to the clause in 1217 does not seem to me, as it does to McKechnie, inconsistent with its spirit. It is an addition to make its correct legal interpretation easier.

On clause 61 I have little to add to what has been said in chapter IV. I would repeat that the clause rests upon a clear provision of the feudal law of wide existence and that in all the details of the clause the barons were well within their rights as vassals. It may be objected that they had no right to assume a judicial function belonging theoretically to the king. But in the first place if this were admitted it would be requiring them to modify their feudal right by a theory of kingship which had no existence in the feudal law, and which they seem to be protesting against elsewhere in the Charter, and in the second place, if they chose to limit their general right of insurrection against an unfaithful suzerain by providing a new chance of avoiding the necessity and by 37 See Cal. Close Rolls, 1234, p. 592 (Shirley, Royal Letters, I. 455); M. Par., V. 501 ; and the ordinances of 28 March, 1259, Rymer, I. 381. 


\section{ORIGIN OF THE ENGLISH CONSTITUTION}

establishing a commission to determine whether in any specific case the right really did accrue, their action cannot be attacked on the ground of its legality.

I repeat also that clause 61 is by far the most important in the Charter because it reveals to us more clearly than any other clause the ground of right upon which the barons supposed themselves to be acting in the whole movement, insurrection and Charter alike. It does this because it shows us upon what right they rested the "sanction" of the Charter as a whole and upon what right they provided for a repetition of the movement against the king if it should prove to be necessary in the future. It is to my mind as nearly demonstrated as any historical inference can be, from the nature of the Charter as a whole, as well as from clause 61 , that they found this right in feudal law. It was feudalism of the age when the feudal system was at its highest point, feudalism ideal and uncompromising, in so far as it understood what it was doing, which spoke in the Charter and uttered its protest against a new royal power, a new royal judicium and a new royal financial system, hostile to itself as it was beginning to perceive. The culminating age of feudalism in practical affairs had indeed already passed, but of that the barons were not aware, and to them it seemed that their protest might be effectual, and the line of political advance be changed. It was of great 


\section{MAGNA CARTA}

moment to us that they failed, but it was of vastly more moment that they made the attempt.

If the results of Magna Carta were to be so creative in our history, at the instant it seemed to demand but little change. Unless we look to a future still distant, we can call it change only by insisting on its character as reaction. And in spirit, in method, and in principle, from the narrower point of view of 1215 , it was reaction. If we regard the political necessities of the time, or the principle on which must rest the royal right to carry out the innovations which had been made, in the light of any political science which had up to that time been formulated, we must admit that the king was right and the barons wrong. Nor is the cause of the barons made better by any foresight, or any guess at wider applications of this principle. Their interest was wholly personal, selfish, and temporary. If instead of regarding principle we look to the side of forms, the only change we can find is also reaction. The law which the Great Charter asserts is old law. The things which are new in it, apart from those which are wrong and quickly abandoned, are unessential details or methods of enforcing rights. What was new at the time were the royal innovations, as in the judicial system and taxation, and if we judge them by what increasing business and the needs of government called for, or by the rapid social transformation which was taking place in the community, we must call them advance and the baro- 


\section{ORIGIN OF THE ENGLISH CONSTITUTION}

nial demands reactionary. It is the unintended result which followed in course of time, which gives to the rebellion of 1215 its right to be regarded as the first step in the formation of the English Constitution.

It is, therefore, not in details of form and law that the permanent influence of the Great Charter is to be sought. These almost wholly disappeared, or where they became permanent features of Anglo-Saxon public law, it is in a meaning greatly broadened by later experience. To repeat what has been already said, the controlling and moulding power of the Charter in English history is to be found in two things: First of all in the principle upon which it rests that there is a definite body of law by which the king's action is bound, and, second, that, if he insists upon violating it, he may be compelled by force to desist. It is not asserted that the barons of 1215 were conscious of this as an abstract principle, or that they could have formulated it in precise terms. They did not attempt any theoretical justification of their action; they could not even feel the need of it in the stage of political development in which they stood. In any case their ideas seem all to have been concrete and practical, and in their remedies they went no further than the correction of the specific abuses from which they suffered, and the difficulty, also specific, of securing the king's observance of his promises. But it seems clear that the Charter and the whole movement of which it formed a part proceeded on the 
supposition that the existing law already bound the king, that many acts of his had been illegal, such as he was bound not to commit, and that the existing law also gave to the barons full right to insist, to the point of armed rebellion if necessary, that these acts should cease and that for the future the king should observe the law, and in such an understanding of their rights under the law as it existed, the barons were undoubtedly correct. I shall now endeavour to show that it was this principle which gave the Charter its influence in the period immediately following, and ultimately its great place in English history. In the slowly developing crisis of Henry III.'s reign, what men saw in the charter in its bearing on their differences with the king was not a body of specific law, but that the king's action was bound and limited, and that the community possessed the right to coerce him. 


\section{ORIGIN OF THE ENGLISH CONSTITUTION}

\section{Note A. The Documentary Series Which Magna Carta OpENS}

\section{(Page 207.)}

The relation in which Magna Carta stands in spirit and in form to the series of constitutional documents which it opens is plain. The historical situation which it presupposes is this, to state it in a generalized form. The king has been doing a number of things which are in violation of the law which he is bound to keep. That at least is the fundamental assumption; I am not vouching for its historical accuracy in every particular. Opposition has arisen to these acts of the king's which are alleged to be contrary to the law. Those who have an influence upon the carrying on of public affairs, enough of them to insure the execution of their plan, are determined that these acts shall cease and that the king shall be formally pledged not to repeat them. A document is drawn up which, directly or by implication, states what the king had done that he should not and pledges him, in a legally binding form and one that can be clearly understood by any one who reads, not to do these things for the future. It may be added that this document comes to be looked upon after a time as a part of the fundamental law of the land, in a more or less ideal light. It is hardly necessary to point out how so general a statement as this of what Magna Carta is, applies to the other documents in the series. If we go on to the next one of them in chronological order which holds a place in common remembrance, the Petition of Right of 1628, the gap in time is a long one. It is bridged, however, somewhat imperfectly to be sure, by the documents of 1258, by the Ordinances of 1310-11, and by the Petition of 31 Articles of 1406. And we know that in 1628 Magna Carta was held in vivid remembrance through the discussions of the preceding twenty years, whether the historical arguments founded upon it were in every case justified or not. It is at any rate, whether by any conscious imitation may be doubted, exactly what is stated above, which is attempted in the

[252] 


\section{MAGNA CARTA}

Petition of Right. Certain four acts of the king, which were thought to be of great importance, are alleged to be illegal, and the king is pledged in legal form to do them no more. Exactly the same thing is true of the corresponding portion of the Bill of Rights. The list of misdeeds is longer, the formulation is sharper and more concise, and the legalizing form is more usual than in the Petition, and in these respects the Bill of Rights is more close to the model of the Charter, but in principle they are all alike. When we come to the Declaration of Independence of 1776 the departure from the traditional form seems more essential, but it is not so in reality. In the fundamental assumption on which the Declaration rests and in the enumeration of illegal acts the tradition is strictly followed. But when it comes to the remedy proposed there is an important departure from precedent. This little corner of the empire could hardly hope, or even propose, to revolutionize the whole, or impose its view of the facts upon the rest. All it could do was to say: these illegal acts affect us so vitally that in our judgment the king is no longer fit to be the ruler of a free people and we must declare ourselves independent. Whether the actual facts justified the colonists in this conclusion or not, does not enter into the present question. It seems to me impossible to deny that in spirit and in form, as far as a form could be followed in the conditions, the Declaration of Independence belongs in the series which opens with Magna Carta, and, except for the speculative political philosophy with which it opens, in which it follows a fashion of its time, it is worthy of the place which it holds in that series.

\section{Note B. Feudal Aids}

$$
\text { (Page 219.) }
$$

ON the statements in the text in regard to feudal payments references would hardly seem to be necessary, the principles are so well known. Glanvill, IX. 8, though concerned with mesne lords only, states them plainly enough. The Leges Edwardi Confessoris, 11, 2, give the practice under William II. While the word 


\section{ORIGIN OF THE ENGLISH CONSTITUTION}

"gratis" is not common in English documents, it is used of a grant to the king in letters patent of May 4, 1236, Madox, I. $607 \mathrm{~b}$, and in the case of aids from rear vassals to their lords in the documents printed in Appendix A, Red Book of the Exchequer, p. cclxvii., for instance Nos. 4 and 5 , and see note 24 above. The documents of the reign of Henry III., as is well known, are full of equivalent expressions. See the de mera gratia et liberalitate sua of the letters patent to the clergy in 1224, Rymer, I. 175, W. of Cov., II. 255, or the de mera liberalitate sua et non alia ratione of similar letters in 1243, Madox, I. $609 \mathrm{c}$. This is said even of the aid of 1235 to marry the king's sister (Madox, 607 b, cf. Stubbs, S. C., p. 364) though this was an aid sanctioned by feudal precedent, when it had not been taken by the father during his lifetime, and possibly one that could have been taken without a special grant; on this point see the returns from the barony of Henry de Ria, Red Book of the Exchequer, p. cclxxiii; and the following from a testament of 1254: Item universis hominibus terre mee remitto et quitto per me et successores meos omnes tallias et ademptiones forsatas et totas, preterquam in IV casibus, scilicet si ego vel heredes mei transfretaremus, vel heres meus esset novus miles, vel maritaret filiam vel sororem suam. Hist. Gen. de Languedoc, VIII. (Preuves) Col. 1330. The pains frequently taken in grants to Henry III. to guard against the estah: $\sim$ hment of a precedent indicates the fear, as is sometimes almost expressly stated, lest a special grant be turned into a customary payment for which no consent need be asked. See Stubbs, S. C., pp. 364, 367, and cf. the liberi adjutarii in contrast to a tallage of $M . P a r .$, IV. 95. The principle of the extra aid and its relation to the regular feudal services is clearly indicated in an actual case, with reference to the ecclesiastical tenth to be paid to the king, in the fourth paragraph of the gravamina of the clergy in 1255. Ann. Burton, p. 361.

The aid was the payment upon the political side of feudalism which comes nearest in idea to modern taxation and also to a payment for economic reasons. It was, however, never looked upon as an economic return in the age of true feudalism, but as 


\section{MAGNA CARTA}

an act or service, though not a service in the technical sense, in which the tenant came to the aid of his lord on occasions affecting the family of the lord or his own person, in the regular aids specified before hand, and occurring only at long intervals. Theoretically they were all occasions when the lord was called upon for some extraordinary expense incidental to his position, though the extraordinary, specially granted aids sometimes depart from this principle. The aid was moreover a service often considered, even in case of the three regular aids, to be voluntary and, like the relief, not of the nature of the tenure, that is, a failure of payment in these cases led not to confiscation but to distraint. Glanvill, IX. 8, 3 ; Bracton, f. 36 b; Viollet, Établ. de St. Louis, IV. 18-20; cf. Flach, Origines, I. 343; P. and M., I. 349-351.

In the ideal feudal state, besides the revenue regularly provided for in the feudal scheme, there would exist those sources of income which were in truth the main dependence of the state in the feudal age, some economic in character, some in part at least political, mostly inheritances from the past: the returns from domain manors, from fines, amercements, and forfeitures, from tolls and customs, from tallages and various regalian rights, some of which were, however, feudal in the strict sense. Nor should we overlook the meeting of numerous expenses of all kinds by serjeanty tenures which, though they were regarded as free tenures, were not military proper. As to the omission of tallage from clause 12, to which attention has been called (McKechnie, p. 279), it would have been clearly beyond the barons' right to insist that it should be included in the clause, if the word tallage is given its technical meaning. They were entirely within their rights in demanding that their consent should be had to extraordinary aids, but tallage is quite a different matter, for which consent was never necessary. Of course the king could have made such a concession, if he had been willing, and then it would have been binding upon him, but there are few cases in the Charter in which the king is made to yield something which the barons had no color of right to demand. 


\section{ORIGIN OF THE ENGLISH CONSTITUTION}

\section{Note C. The Direction of Change in the Reissues of the Charter}

$$
\text { (Page 223.) }
$$

THE question of the purpose which led to the omissions and modifications in the reissues of 1216 and 1217 , if it can be said that they were controlled by a single, general purpose, is one of much importance as bearing upon the character of the original charter and the intentions of the barons in it. If it is true that the changes made in the reissues were in the direction of more exact statement and that there is a tendency to drop unwarranted and doubtful claims, the theory is strengthened that in the original charter the barons intended to state the law accurately and were not trying to take unjust advantage of the king. In the reissue of 1216, fifteen clauses were modified, twenty-two were omitted altogether, and one new clause was added. In 1217, twelve clauses of the preceding year were modified, none was omitted, but seven new clauses were added. The modifications made by the original charter in the Articles of the Barons should also be considered in some cases. The successive changes may easily be studied in Stubbs, Select Charters, or in Bémont, Chartes des Libertés Anglaises. Of the clauses modified in 1216, six, 9, 13, $22,46,47$, and 56 , were so slightly changed that they may be disregarded. Of the others, c. 3 is made much more explicit in 1216; the law as laid down in Glanvill, IX. 4, 2, is more fully stated and a provision is added that the minor shall not escape from custody by being made a knight. Clause 5, which is much improved over art. 3 of the Articles of the Barons, is further changed in 1216, as if from some observation of the working of the original, at least from a careful study, to avoid a demand upon the guardian for more than he had received which might be possible under the first wording. The church is also put under the same provision and the statement is added that ecclesiastical custodies ought not to be sold. The changes in c. 6 are 


\section{MAGNA CARTA}

interesting. In the Charter a demand of the Articles unwarranted by the feudal law, that the marriage of the heir should be made with consultation of his nearest relatives, is "softened down" to a requirement, equally without support in law, that the nearest relative should be notified. In 1216 the attempt to add to the law is abandoned, and the clause about disparagement, which is all that the law warrants, is left to stand alone. Clause 7 , which is more exact than art. 4 of the Barons, is further modified in 1216, as if from experience, by providing that the widow's right to remain forty days in her husband's house shall not apply to the case of a castle, no doubt because it might be needed for public defense, though instead some proper house shall be provided for her. In 1217 the clause is made still more explicit. The widow's right to remain in the capital messuage is to be interfered with only when it is a castle; she is to have her rational estovers until the dower is assigned; and a specific provision about the dower is added from the old law, Glanvill, VI. 1. Even more interesting is the history of c. 20. The Charter greatly improves upon the Articles. In 1216 a single word only is added, proborum hominum, becomes proborum et legalium hominum, but the change removes the danger that the liber homo may be amerced by villani on the jury. In 1217 another difficulty was dealt with. After villanus the words alterius quam noster were added. It probably never was intended to introduce this provision into the manorial courts of the royal domains, or into any except the new royal courts. It is hardly possible that anything more was intended by the clause in its original form than is finally expressed with exactness in 1217, but it underwent steady improvement in every restatement, and certainly the thought is not unjustified that the last changes at least may have been due to attempts to interpret the clause otherwise in the courts. In the case of c. 28 , it would seem again as if the changes were due to actual experience, though the decided improvement in diction of the Charter over the Articles should not be overlooked. The necessity of provisioning a castle may be a pressing one and to provide for such cases the royal officer 


\section{ORIGIN OF THE ENGLISH CONSTITUTION}

may have a delay of three weeks in payment without thc consent of an owner who dwells in the village where the castle is, a limitation which seems to imply provisioning in haste from the immediate neighborhood, and in 1217 this allowed delay is extended to forty days. Clause 30 is changed in 1216 to specify exactly the anciently determined rate of compensation. Clause 41 is modified to reserve a royal right of action in certain cases doubtless for the same reasons which lead to the omission of $c$. 42. It may be added that the principle embodied in c. 43 is carried a step further in 1217.

Of the change in c. 1, I hardly know what should be said. A portion of the clause had to be omitted, or reshaped, because of the reference to King John, and this may be the only reason for the change. It should be noticed that this provision is not included among the dubitabilia referred to in c. 42 in 1216 , doubtless because no demand of doubtful justice was made of the king in the original clause. The theory of the law granted the church all that the clause contained, or that was granted by the charter of John of November 21, 1214. The violation of freedom of election was a matter of customary practice, not a recognized right of the king's. It seems to me very doubtful if the special charter of John of November 21, to the church, would have been regarded as binding his successor. There is indirect reference to his heirs, as if they were supposed to be included, but there were no formal words of grant which would bind any one except John himself. I feel very sure, however, that the words omitted from the reissue were not dropped because of any intention of interfering with the freedom of election of prelates. Practice during the reign of Henry III., in almost all cases certainly, seems to have been in accordance with the promise of c. 1, of 1215, or of the special charter of John. M. Par., III. 493-495, probably shows the extent and method of an extreme case of royal interference. Of some influence at work in these alterations in 1216 hostile to the national church (McKechnie, p. $167 \mathrm{n}$. ) I cannot find any eridence.

Certain other clauses which escaped modification in 1216 were [258] 


\section{MAGNA CARTA}

changed in the reissue of 1217 , but of this reissue I think we may say that in the general tone of its changes and additions there is some indication that the strain of the conflict with the king has been relaxed and that problems of everyday government are having a larger share of attention than in 1215. A good proportion of what is new to the charter is legislative in character, that is, new to the law as well $(13,14,15,26,39,42,43)$. There seems also a tendency to use the opportunity in the interest of the baronial class $(26,35,39,40,43,46$, and I think possibly 13,14 , and 42) - a tendency which shows itself at least as plainly in the Forest Charter. The changes which were made in 1217 in clauses 18 and 19 of the original charter were undoubtedly in the direction of a relief from the burden of too frequent and exacting judicial service. Clause 38 is broadened in statement. Clause 39 is enlarged to say that the disseisin without judgment from which the free man is protected includes not merely his land but his "liberties and free customs" as well-an addition plainly in the interest of the greater barons, but one strictly legitimate, making the clause more complete and exact. To c. 43 is added a sentence, very badly expressed, if we have it as first written, to say that in the application of the principle laid down in c. 37 (1215) the tenant of a barony in the king's hands shall not be regarded as holding in capite (Bracton, f. $87 \mathrm{~b}$ ); an entirely legitimate addition, changing no existing right. While the language of c. 46 is made somewhat more exact in 1217, possession is added to a charter or ancient tenure as sufficient proof of the right to the patronage of an abbey. There can be, I think, no reasonable doubt but that the framers of the clause intended that antiquam should qualify possessionem as it does tenuram. If so, it would represent fairly the baronial view of the existing law, but this view was never fully accepted by the crown (Stubbs, S. C., p. 384, Petition of the Barons, c. 11; Maitland, Man. Courts, p. lxxvii.).

There should be noticed here the attempt made in c. 44 of this reissue to restate the point of c. 12 of the original charter, but I do not think the barons drew up this clause in 1217 with 


\section{ORIGIN OF THE ENGLISH CONSTITUTION}

any feeling that they had solved the difficulty. Their statement has rather the appearance of an effort of despair. "We don't know what to say; let us say this." Nor does it seem to me likely that they knew very much about how scutage had been taken in the time of Henry II. They called for this as the Laga Edwardi had been called for in the coronation charter of Henry I.- the ideal method is found in the time of some famous king in the past.

The general trend of the omissions of entire clauses in the reissues is even more evidently in the direction of a more accurate statement of the law. Of these 48-53, 55, 57-59, 62 and 63 , may be disregarded as being temporary in character in the original charter, or needing to be dropped because of the change in the throne or in the form of the charter, and 12,14,15, and 61, are sufficiently discussed elsewhere. Of 10 and 11 of 1215 , it is to be said that while they undoubtedly corrected some cases of injustice, they at the same time created others, and, so long as the Jew was regarded in law as the king's serf, a charter whose object was not new legislation but a statement of existing law, was going beyond its limits in these clauses. Correction of the abuses referred to was later made by statutes, as in 1236 in c. 5 of the statute of Merton (M. Par., III. 343; Ann. Burton, p. 251). Clause 25 was clearly unjust as has already been said at sufficient length. Clause 27 may have enacted a desirable reform, but it clearly made a change in the law as it stood (Glanvill, VII. 16, 2; Round, Calendar, p. 478; Viollet, Etabl. de St. Louis, II. 150-152, IV. 42-49). Of both clauses 42 and 45 it must be said that they took away from the king clearly recognized prerogatives, long established in use; that they are, therefore, both legislative in character; and that upon the principles of the main body of the charter they would be hard to justify. On the decision of Louis IX. in the Mise of Amiens, in January, 1264, against the principle of c. 45 , see note 35 above; a correct decision so far as the question was one of law merely. Nearly all these clauses are referred to as dubitabilia in 1216, and that is given as the reason for their omission. All indications point to 


\section{MAGNA CARTA}

the fact that the barons who reissued the charter, when they said this, were making an honest statement of their reasons. It has been generally believed that the purpose of the omissions, and of some of the changes, was to remove restrictions which the charter had placed upon the power of the crown now that the barons were themselves to be responsible for the carrying on of government (Stubbs, II. 21; McKechnie, p. $165 \mathrm{ff}$ ), but some of the evidence supposed to show this purpose is not to the point. It is, for instance, an incorrect interpretation of c. 12 which regards it as restricting any legal taxing powers which the crown had possessed, or its omission as increasing those powers. While it is no doubt true that the omitted clauses would have secured, if they had been allowed to stand, some interests of the barons as against the crown, no one of them enacted any essential limitation upon a royal absolutism. There can be no doubt, however, but that the reissue of 1216 does leave the crown in many particulars a freer hand. If the Charter were to be improved in accuracy and legality, any other result was impossible. The whole object of the original Charter was to put restrictions upon the king, upon his illegal action and his usurpation of rights. If in some cases in their zeal the barons went beyond their rights and interfered with prerogative acts of the king's which the law allowed him, to correct these errors, to make the charter conform as nearly as they could to the law as it stood, would necessarily have for result to free the king's hands in these respects. To show that the Charter of 1216 allows to the king some greater liberty of action than that of 1215 is not to show that to do this was the purpose of the barons in making the changes. A minute analysis of the four documents will show, I think, conclusively that from the Articles of the Barons to the reissue of 1217 there is evident on the part of the barons an honest intention to state their rights only within the limits of the law, to deprive the king of nothing to which he could justly lay claim, or having done so to withdraw the demand, and to make their statements of the law more clear and full, more accurate and just, wherever they learned of the possibility of improvement. Some clauses of the reissue 


\section{ORIGIN OF THE ENGLISH CONSTITUTION}

of 1217 were, it is true, new legislation, like 39 and 43 , but these clauses interfere with no rights of the crown and are in themselves easily defended.

Note D. Magna Carta, Clause 39

(Page 242.)

ThE fundamental difficulty in the interpretation of c. 39 is that created by the last phrase, nisi per legale judicium parium suorum vel per legem terræ. It would be more accurate perhaps to say difficulties, since problems of more than one kind are created by these words, but the most important question to be settled is the translation to be given to the word vel. Shall we say according to classical usage "or," or according to the usage frequent in medieval writers "and"? No one will, I think, be disposed to take seriously Mr. Vernon Harcourt's assertion, Steward, p. 224, that the conjunctive use of $v e l$ is always a blunder. This additional meaning of the word is too well established to admit of question. See for example index s. v. vel, of Wölfflin's ed. of Benedict's Regula (Teubner), p. 84; Liebermann, Einleitung in den Dialogus de Scaccario, p. 84, n. 1 ; and Du Cange s. v. A conjunctive interpretation of $v e l$ in this plurase receives some support from the use of the word in the first part of the clause. The change there from vel to aut can hardly have been otherwise than conscious and intended; it implies almost necessarily that capiatur and imprisonetur were looked upon by the writer as together constituting one act, coordinate with those that follow, imprisonetur being the really important idea. There should probably be no comma after capiatur and we should translate: "no one shall be arrested and imprisoned, or." It must be admitted, however, that this interpretation cannot be applied to c. 29 of the Articles of the Barons and that fact should be allowed such weight as it may be considered to deserve. In my opinion it is to be taken as one of the cases of more exact statement in the later document. The Charter as a whole is, moreover, so 


\section{MAGNA CARTA}

inconsistent in its vocabulary that it is not possible to quote with any confidence one portion of it to determine the meaning of words in another. More conclusive is the evidence to be derived from an examination of the other words of the phrase as used in contemporary material. Such an examination shows for one thing that the words legem terra may be taken to mean the compurgation procedure, as that was used in the older courts. See, for one instance, Bracton's N. B., pl. 325. But there is so far as $I$ have been able to ascertain no case of per legem terra in this sense. The material to be searched for such a case is, however, so vast that I hesitate to assert that there is no one to be found. On the other hand, it is equally certain that lex terre frequently means the law of the land in a broader sense, the whole body of law and custom by which rights as well as procedure were regulated. Instances of the use of the words in this sense are to be found in intimate connexion with the general meaning of c. 39 in cc. 56 and 57 of the Charter, where, however, they are preceded by the preposition secundum. Of judicium more than one meaning can be proved, but of judicium parium taken together only one, so far as I know,- - the judgment made by the assembly in a court of peers, though the word might as accurately be applied in many cases to a manorial as to a baronial court. If now with these meanings of the words which it connects, we give to vel a disjunctive force, the clause is reduced to a practical absurdity. If legem terre is taken to mean the compurgation procedure, we have an alternative proposed between this and judicium parium which never could have existed. The king would be required to choose one or the other, but such a choice was impossible. Compurgation never took place except upon a judicium parium, or what would be its exact equivalent in a popular court, a judicium curia, and it was, in theory at least, always followed by another determining the final judgment of the court. It is not possible to suppose that a writer as familiar with the judicial procedure of his time as the onc who drafted the Charter certainly was would have separated two essential parts of a continuous process by a disjunctive particle, offering 


\section{ORIGIN OF THE ENGLISH CONSTITUTION}

a choice between them. If on the other hand, we take the broader meaning of legem terra and interpret the phrase "by judgment of his peers or by the law of the land," we have a result which is only less impossible, and equally absurd, since the second which is offered as an alternative to the first necessarily includes it, the judicium parium being a very essential part of the body of law by which all rights were protected and not to be separated from it as a different thing. It would not have been possible for any one to invoke the protection of the law, at least under the traditional system, without invoking at the same time a judicium parium. The only admissible interpretation of the clause which I have seen on the assumption that vel is disjunctive, is that suggested by Stephen, Criminal Law, I. 162-163, that it means by the judgment of his peers, if he is a vassal of the king's, and by the law, that is, as the law of the land provides, if he is not. There is, I think, no objection to this explanation except that the language of the clause hardly warrants us in supposing that so fine a distinction was in the minds of the barons. If they had intended to say this, they would have said it much more plainly. Certainly this distinction was not in mind in the corresponding phrase in the letters patent of May 10, quoted below, where we should expect it if anywhere, because the rear vassal had just been expressly named. I am inclined to think that in this clause the barons had in mind only the members of their own class, who would have suffered most severely from the arbitrary extrajudicial action of the king, nor do I think that any intention of general application can be proved by the words nullus liber homo. It seems to me at least clear that the words liber homo are not used in any consistent sense in the Charter. In c. 20 the whole baronial class proper is in intent excluded. In c. 34 the baronial class alone is meant by the term. It might seem to be pressing the matter a little too far to say that the classes referred to in these two clauses do not overlap at all. Clause 20 includes, as Bracton states, f. $116 \mathrm{~b}$, the simple knight who possessed say only a single fee, or a fraction of a fee, who may often have been reckoned in 1215 as a minor baron, but the cases would be very 


\section{MAGNA CARTA}

few in which the simple knight would possess a feudal court trying cases which would be likely to be evoked from his court by the writ Præcipe. Such cases would be so few that I think it is not going too far to say that the classes which the barons had in mind in the two clauses were mutually exclusive. Liber homo in c. 34 certainly includes only those possessing a baronial court trying cases of greater importance than those usually coming before the ordinary manorial court of mixed jurisdiction over the class of serfs and common freemen. The words are, however, generic and may have been used in both 34 and 39 to be sure to include everybody who should be included, but they might also have been very naturally used of tenants-in-chief, who were regarded throughout the feudal world as preeminently free men, and without any thought that others might be included in the term. They would form also almost exclusively, the class exposed to the abuses forbidden. The words, liber homo, however, in their general use do certainly include the rear vassal, and so far as language goes it does not seem to me impossible to say, as Mr. Beardsley has done (Law Quart. Rev., V. 125), that "it may reasonably be suspected that c. 39 also was directed merely to maintain the lord's court against Crown encroachments," though I think the word "merely" should be omitted. But it does seem to me unlikely that the barons intended to include under the words any freemen outside the vassal class. I express this view in qualified form and hold it subject to correction since the other is universally held, but as the words judicium parium were commonly used, and as they would naturally be understood by those who wrote and those who read the Charter in 1215, I feel quite sure they can have meant a feudal court only, excluding from this term of course the manorial court proper. If the popular courts, and the non-vassal freemen in those courts, had been in mind as one of the things to be covered by the clause, other words or more words would have been used. And this appears to me to be true notwithstanding the fact that judicium parium can be explained in one sense so as to include the action of the popular court and rery likely instances of such a use can be cited.

[265] 


\section{ORIGIN OF THE ENGLISH CONSTITUTION}

If on the other hand, we give to vel a conjunctive meaning and suppose it to be equivalent to $e t$, there can be found an abundance of evidence to support what would seem to be the simple and natural meaning of the phrase: except by the judgment of their peers and by the whole body of law and custom which such judgments are intended to interpret and apply. There can be no possibility of doubt that this is the meaning of the closely equiralent phrase, which has been often quoted in this connection, from the constitution of the Emperor Conrad II. of 1037, Mon. Ger. Hist. Legum., Sec. IV., T. I. 90. Nullus miles . . . . sine certa et convicta culpa suum beneficium perdat, nisi secundum constitutionem antecessorum nostrorum et judicium parium suorum. The similarity between the two phrases is to be explained not on any ground of historical connexion or imitation (Stubbs, I. 578), but because both grow out of exactly the same conditions of feudal law and procedure in an effort to provide against the same possibility of danger. The order of words is transposed in Conrad's constitution, but that is of no importance. It is also transposed in the letters patent which John had issued on the tenth of May in an attempt to win the barons over, or to break up their party (Rymer, I. 128). It is evident that in issuing the letter this demand of the barons was specifically in mind and the phrase reads: Sciatis nos concessisse baronibus nostris qui contra nos sunt, quod nec eos nec homines suos capiemus nec dissaisiemus, nec super eos per vim vel per arma ibimus, nisi per legem regni nostri, vel per judicium parium suorum in curia nostra. This letter is of special interest because it shows an opinion among the king's party that the barons regarded this as one of their most essential demands. If they could obtain this they might be willing to go home. It is also of interest because while the rear vassal is clearly included in the enumeration of persons, the exceeding carelessness of the phrase per judicium parium suorum in curia nostra, requiring an impossibility if strictly interpreted, shows conclusively that procedure was not the thing they had in mind, and that there was no dependence of the legem of which they were thinking upon a judicium, that is, the legem in this 


\section{MAGNA CARTA}

instance was not compurgation. What they demanded was the right and justice secured by the general body of the law operating through the processes most familiar to them. This is clearly the meaning of the words attributed by Roger of Wendover to William de Braose (M. Par., II. 524), when he says that he is ready to satisfy the king, secundum judicium curiæ suæ et baronum parium meorum. Had the word secundum been used in this clause of the Great Charter it would not have been necessary to give so much study to the phrase. The pope certainly understood the language in that way as he makes clear both in his bull absolving John from his oath to the Charter and in his letter to the barons of the same day. The letter reads: Præsertim cum in causa ipsa vos judices et executores feceritis; eodem Rege parato, in curia sua, vobis, per pares vestros, secundum consuetudines et leges regni, justitiæ plenitudinem exhibere. Rymer, I. 136. Secundum and per seem to have been to some extent interchangeable in such phrases, at least the utlegatus per legem terræ of Glanvill VII. 17, 7, becomes utlegatus rite et secundum legem terræ in Bracton, f. 128 b. There can be no doubt, I think, that c. 39 was in mind in drawing up c. 56, but there we have per judicium parium suorum secundum legem. An interesting parallel is an interpolation by a London writer about 1210 in Leges Henrici, 8, 1(Liebermann, Gesetze, I. 554, d.). Quia nil a nullo exigi rel capi debet nisi de jure et ratione, per legem terre et justitiam et per judicium curie. In case of the courtesy right of the husband to hold during life the maritagium of his deceased wife he is always said to hold per legem Anglice. See Bracton, ff. 205, 215. The serf is said to be in a free status until the lord claims him per legem terre. Bracton, f. 7. In Bracton, N. B., c. 1268, the court tells Peter that if he thinks he has any right in the land in question perquirat inde sibi per legem terre versus Gilibertum. It would be possible to multiply indefinitely evidence of this kind, if there were any need of doing so. I have no doubt in my own mind that what the barons wished to protect by this clause against the arbitrary action of the king was their right to the 


\section{ORIGIN OF THE ENGLISH CONSTITUTION}

traditional curia regis trial by their peers according to the law of the land and enforcing their rights as defined by that law.

If any one thinks, however, that per legem terra must refer to procedure, there can be no objection, except its general improbability, to the translation, "by judgment of their peers and by compurgation." In that case it is procedure of which the barons were chiefly thinking and then there is considerable likelihood that what they were objecting to was the new royal justice as established by Henry II., including the jury, the itinerant justice court and the permanent central court of Common Pleas. See McKechnie, p. 449, and the references there. I think the King's Bench can hardly have been included in 1215. If the intention of the clause was really to prevent the extension of this new royal justice to cases coming naturally before the old curia regis, the only way to do it would be to emphasize the judicium parium and pledge the king not to depart from it. It is not an answer to this suggestion to say, as has been said, to disprove the traditional interpretation of judicium parium as the jury trial, that in criminal cases trial by jury had not yet been instituted (Pike, House of Lords, 169). This is quite true of the petty jury and it is a sufficient answer to the traditional view, but if proposed against the interpretation of c. 39 just suggested, it would overlook the fact that in 1215 the action of what later becomes the grand jury was an integral part of the trial of criminal cases in the new royal justice as has already been indicated. It does not seem to me correct to say as Bigelow does (Procedure, p. 307), that the Assize of Clarendon substituted the ordeal for compurgation in the old procedure. What it did was to substitute the action of the accusing jury for all that part of the procedure which went before the ordeal, leaving the case against the accused as it stood in the popular court when all had gone against him down to that point. See chapter III., pp. 116-120. It is indced not until long after 1215 that the action of the accusing jury ceases to be a part of the trial and comes to be merely a method of deciding whether there shall be a trial or not. In saying that no jury ever did or could give 


\section{MAGNA CARTA}

a judgment, Mr. Pike (Ibid., p. 169; cf. P. and M., I. 173, n. 3 ), seems to me also to be thinking of the jury in its modern use and to be applying the idea to the accusing jury in a medieval case. It was by a judgment of the court that the right of making the oath, that is, compurgation was assigned in a given case, and though the action of the accusing jury stood for the result of a compurgation rather than for the judgment assigning the oath, it took the place of the whole process, and could not have seemed very different to the actors from a judicium curia, for that always implied an opinion of guilt or innocence. In this respect the action of the accusing jury in a criminal case is distinctly different from that of the assize jury in a civil case. It should be remembered that in a twelfth century court judgment was never pronounced by those who made it. It was pronounced by the moderator of the court who had no voice in making it, and was made by the assembly which had no power to pronounce it, except as that power might be delegated to one or more of their number by the moderator. I think it likely, however, that, if c. 39 refers chiefly to procedure and was due to a fear of what the royal justice might lead to, it was directed less against the jury than against the growth of courts tending to be formed exclusively of professional justices and excluding any real judicium parium. It is hardly likely that such a tendency would be noticed when the itinerant justice court and the central court corresponding to it were first formed under Henry II. But from their beginning these courts would probably assume the same jurisdiction as the great curia regis, that is, the only line drawn between its jurisdiction and theirs would be that drawn between the old great curia and the small, viz. the importance of the case or of the parties, or the mere convenience of the moment. This would seem at first a perfectly normal arrangement, and it would only be as the barons became conscious of the attack all along the line which the judicial reforms of Henry II. were making on their private jurisdictions and personal feudal rights that they would begin to see that the jurisdiction of the great curia regis was being under- 


\section{ORIGIN OF THE ENGLISH CONSTITUTION}

mined, its cases purloined from it, by the growth of a court in which there was a judicium parium only in theory and that, too, theory of a very bald sort as they would regard it. That in theory, and in very plausible theory from the king's point of view, the justice was the baron's peer cannot be denied. As has already been said, the peers of the curia regis, both as great and as small curia, were the king's immediate vassals who might be present, and such others, household officers or persons of any kind, as the king might summon for the occasion. I do not know of any case where the presence in the old curia regis of this specially summoned, which might at any time be a nonvassal element, was ever objected to either in England or in France before the thirteenth century on the ground that persons composing it were not peers of the vassal according to a strict definition. In France in 1224 we have this point raised by the baronial element in the curia regis against the official element in the well-known case of John de Nesle against the Countess of Flanders, and decided by the court against the barons on the ground of custom and precedent. Langlois, Textes Relatifs a l'Histoire du Parlement, p. 35, No. XXI.; Boutaric, Actes du Parlement de Paris, I. cciii. c. 2; Williston Walker, Gronth of the Royal Poner in France, p. 82; Vernon Harcourt, Steward, p. 271; Petit-Dutaillis, Louis VIII.; p. 349. But by this date in France the question of an exclusive peerage had already come forward in other ways, as it had in England. Apparently some, more or less conscious, effort was made to preserve the idea of a judicium parium in the new royal courts. At least this is one obvious interpretation of the phrase used in slightly varying forms as a part of the formula in the numerous fines of the later years of the twelfth century, for example, in a fine of 1189 made at York, we read, after the names of the justices: tunc justiciariis domini regis, et coram aliis baronibus et fidelibus domini regis, qui tunc aderant. Guisbrough Cart., I. 167; Surtees Soc., Vol. 86. I have chosen purposely one of the fuller forms, but the same meaning is, I think, implied in all. Such a form of words would probably seem to be a satisfactory 


\section{MAGNA CARTA}

statement of the facts in the early years of this royal justice. As it came to be perceived, however, that it was a mere form of words to which there was no corresponding fact in the actual composition of the court, there would be very likely to occur cases in which protest would arise. This may well have been the real point of the plea of the abbot of Leicester in 1200, cited in Maitland, Select Pleas, p. xiv., from the Plac. Abbr., 32 , for, if we may suppose that they were making technical distinctions, an appeal at that date of a case coram rege from the Bench would be an appeal from a court in which the professional judge would certainly be the predominating element to one in which the old method of trial by peers could still be had. If we could suppose this explanation correct, and of course that cannot be asserted, we should have here the two ideas of the character of the new courts meeting, the assertion of the party in the case that it was not a court of peers and the assertion of the court in deciding against him that it must be so considered. That this last assertion can no longer be made for the itinerant justice court at least, as a consequence of c. 21 of Magna Carta, is indicated by the mandate cited by Madox, I. 529, $o$, and cf. P. and M., I. 411. The reference there to Bracton, f. $116 \mathrm{~b}$, should lead us to notice that in his time it still seems quite natural that an amercement by the barons of the Exchequer should be equivalent to, or better should really be an amercement coram consilio. The idea that the Exchequer was a true small curia regis was not yet lost sight of-though the Common Bench had so plainly become professional. The Miror of Justices, I. XIV. (ed. Whittaker, Selden Soc., p. 36), shows the natural continuation of this view into the early portion of a period when the Exchequer was becoming a common law court. Bracton's N. B., c. 1213, would indicate the same feeling on a coram rege case in 1226-27. That in times not long after 1215, the bearing of the growth of a class of professional justices upon trial by peers was thought upon and troubled the minds of the barons is clear from the taunt of Peter des Roches in 1233 (1. Par., III. 252). To the demand of the rerolted earl 


\section{ORIGIN OF THE ENGLISH CONSTITUTION}

Marshal and his friends for trial by their peers, Peter replied: quod non sunt pares in Anglia, sicut in regno Francorum; unde licet regi Anglorum per justitiarios, quos constituerit, quoslibet de regno reos proscribere et mediante judicio condempnare. That so categorical a statement was as truly a misrepresentation of the actual facts in France as in England is probable, though this is not the place to enter upon that subject. See Vernon Harcourt, Steward, pp. 269-273. In truth this conflict of ideas and institutions, which was to be fought through in France as in England and upon the same issues, resulted in a more complete, though really barren, victory for the class at large in England than in France, and to this victory clauses 21 and 39 of Magna Carta certainly contributed, whether the barons had the specific point in mind in 1215 , or not.

As I have already said, it seems to me more likely that this was not what they were chiefly thinking of, that they were here less concerned with the contrast in procedure between the old curia regis and the new royal justice than with John's tyrannical treatment of his vassals without any process of law of either kind. It, therefore, also seems to me hardly likely that the abuse of which they complained in the clause was very closely connected with those summary writs of execution without trial which are discussed by Bigelow, Procedure, pp. $151 \mathrm{ff}$. These writs were closely related to the writs of right which were plainly considered as a legitimate exercise of the king's prerogative, and it does not seem likely that they were in themselves frequent enough to gire rise to such a complaint. It is, indeed, doubtful if they could have been considered, where properly used, as an abuse at all. The king undoubtedly sometimes rendered justice in person in a case, as being the fountain of justice, and it is possible that he did so occasionally on $e x$ parte evidence but probably always in such cases the decision concerned seisin only and would be, as in the case of the possessory assizes, preliminary to a trial of the actual title. See the writ of Stephen printed by Round, Commune of London, p. 114 , and Round's note. It is quite possible that some incidents 


\section{MAGNA CARTA}

which seem to us prerogative judgments are really cases where A, the defendant baron, who has been ordered by a Præcipe writ to do justice to $B$ or explain in a king's court why he has not done so, elects to satisfy B's demand at once rather than to let the case come on for trial. It is highly probable that such cases occurred. The whole subject, however, of the king's prerogative right which lies back of all this class of writs needs further investigation and nothing can at present be said of it with confidence. In any such study care should be taken to distinguish between disseisins which were confiscations, and those which were distraints merely and not intended to disturb title without a subsequent judicium. It should be noticed that in c. 52 of the Charter the barons virtually admit that disseisins of the kind of which they complain in c. 39 had been made by John's father and brother. It seems to be clear, however, that the barons were demanding in c. 39 that some action of the king's should cease which was violent, arbitrary, and tyrannical in character, and in the main, perhaps wholly, it relates to cases where something like punishment for crime is inflicted and not to interference affecting civil cases. The disseisin of land referred to, if we may judge by the context, is confiscation, not the transfer of seisin from one claimant to another. Of acts of injustice of this kind by the king, we have some evidence but not enough as yet to solve the difficulties of the case. See McKechnie, p. 438; Bracton, N. B., pl. 76; 401; 769; 1330; 1500 ; 1593 ; Madox, I. 26, a, and Form. Angl., No. 521. Cases from the chroniclers should be added indicating the popular belief about the treatment of those captured with Arthur at Mirabeau, of the family of William de Braose, of Ralph Fitz Walter and Saher de Quincy. Disseisin of land "sine summonicione et sine judicio" was not ended by c. 39. Cf. Bracton, N. B., pl. 1106 .

By far the best discussion of this clause to be had is that by McKechnie. Reference should also be made to Pike, House of Lords, chapter X., and to Vernon Harcourt's Steward, chapters VII. and VIII. This last is a very helpful study, but it is not 


\section{ORIGIN OF THE ENGLISH CONSTITUTION}

always based on a full understanding of the feudal law, and it sometimes demands that the baron of 1215 should have used the language, possessed the ideas and foreseen the difficulties of the man of 1907 . 


\section{CHAP'TER VI}

\section{The Immedate Results of Magna Carta}

Clause 61 of Magna Carta comes nearer to putting into words the principles on which the barons acted, and on which the whole Charter rested, than any other portion of the document. But clause 61 is found only in the Charter of 1215. It was dropped from all reissues after the death of John and was never afterwards restored in any form. Again, it has been asserted of the Charter as a whole by an acute critic of English law and history ${ }^{1}$ that, from its reactionary character and its consecration of the past, it proved "a positive stumbling block in the path of progress." He declares that this fact began to be perceived in the reign of Henry III.; that it was then seen that the Charter was not enough; and that the barons at the Parliament of Oxford in 1258 attempted an entire break with the past. If the origin of the English Constitution is to be ascribed to the introduction into history as an active influence, of the principles which were most nearly formulated in clause 61 , as affirmed in chapter IV., both these objections must be met.

Far too much has been made of the dropping of 1 Professor Edward Jenks in an article entitled "The Myth of Magna Carta," in The Independent Review (1901), IV. 260-273. 
clauses from Magna Carta. Clauses 12 and 14 are usually thought of in that connection, perhaps because the historical importance of clause 61 has not been fully recognized, but the case is the same for all three. A little reflection ought to make it clear that, in all that was really important, the omission of these clauses made no difference either in the law as it stood, or in the fact that the king was bound to obey it in the particulars which they stated. ${ }^{2}$ With the exception of some minor details, which concern chiefly questions of method, the provisions of these clauses were all drawn from the feudal law; their existence there the king could not deny; and he was

2 The board of twenty-five barons and its method of operation of course disappeared, but as far as the future is concerned this clumsy piece of machinery was not the essential point in c. 61 . From c. 14 there may possibly have disappeared some new points of detail, if they were new, but I think rather that all its provisions remained in force. Clause 14 is interesting in some minor points, but it was from the beginning an unnecessary addition to the Articles of the Barons and quite without importance. If it had been retained it could have had no influence whatever on the development of Parliament. In c. 12 the barons seem to have been led by a difficulty of formulation into a demand in regard to scutage which custom did not warrant, and this was given up, but what they were trying to say was not given up, nor anything else in the clause. There is evidence that the barons carefully guarded their rights in taxation. See Shirley, I. 151 (the action of the county court which Stubbs, II. Sec. 209, supposes in this case is not evident in the text); $\boldsymbol{H}$. Par., III. 200; V. 520. On the last reference, see McKechnie, p. 301, n. 1. The idea that the curia regis, described in c. 14, might be made the basis of constitutional machinery to enforce the Charter was wholly beyond the political horizon of the barons in 1215. The idea "constitutional" was an outgrowth of the fundamental law, binding the executire, then beginning its slow formation, and it would be impossible until there should be a considerable experience of enforcing that law against the king; there was needed an equally slow transformation of the curia 
just as much bound to regard them before June, 1215, and after November, 1216, as during the time when they formed a part of the Charter. The Charter was not drawn up to make these provisions law. The crisis had not arisen because the law was inadequate. The whole movement against the king proceeded on quite a different theory. The Charter seemed necessary because the king persisted in violating the law and could not easily be restrained. Its main purpose was to state the points which the king had violated, not in order to make them legal, or binding on him, but to secure from that particular king, because of what he had done in the past, a clear and formal acknowledgment of their legal and binding character and then to get his agreement to machinery for enforcing them in the future. ${ }^{3}$ If John had had

regis into the later Parliament, changing its relation to the other elements of the case, community and king, before it could be looked upon as the natural guardian of the fundamental law against royal encroachment. It would be the natural thought or the barons in 1215 that something new was required to meet the special need. This is what they sought to get in c. 61 , and c. 61 was in harmony with the age and all that was possible to it. That it should be omitted in the reissue of 1216 was inevitable. However true it might be that the principle on which it rested was within the right of the barons, the method it enacted was revolutionary. No gorernment could issue such a clause as a part of the law which it proposed to recognize without confessing its habitual disregard of its own duties and of the rights of others. Moreover, if the government could be trusted to administer affairs in harmony with the Charter, c. 61 was unnecessary. The commission of twenty-five would have no work to do. See $A . H . R .$, V. 619 , n. I.

${ }^{3}$ Of course I do not deny that there was some new legislation in the Charter, as I have already indicated, and some definition of doubtful points as the barons wished them defined, but these were incidental and of secondary importance. 


\section{ORIGIN OF THE ENGLISH CONSTITUTION}

eren as much regard for the law as had William $I$. in his time, the Charter would have been unnecessary, but the law which it states on these points would have been in force very much as the barons wished it to be.

This then is to be said with regard to the omission of clause 61 from the Charter: the fact did away with the committee of twenty-five, but did not affect the underlying legal principle on which the clause rested. In truth, the fate of this principle, and of all that was contained in the Charter of 1216, and of the whole body of law by which the king was bound, depended not upon the words of the Charter but upon the character of the following age, whether the government should be conducted in harmony with the spirit of the Charter and its principles developed in natural and orderly growth; or by a strong king in a spirit hostile to these principles until they should become forgotten and obsolete; or as a third possibility by a weak king in a spirit neither consistently hostile nor friendly. In this latter case all growth would seem, more clearly than in the other two, to be determined less by historical precedent than by the stronger currents of the age and the uncertain action of revolution. As a matter of fact, the impression made by the baronial revolt against $\mathbf{J}$ ohn on the next generation seems to have been as decisive an influence in its history as anything in the language of the Charter itself, and it perpetuated not merely the Charter but all the circumstances and purposes of the insurrection. 
When we turn to the second objection and consider the influence of the Charter as a definite body of law, and its relation to the next step forward-the Provisions of Oxford in 1258-we approach a more difficult question and one whose definite answer would require an extended and minute examination of the reign of Henry III. It is, however, a most important question. It must be considered here in some detail, and on its answer depends our understanding of the constitutional development through this critical age.

A fair regard for the law really describes the state of things for many years after the accession of Henry III. The Charter was reissued immediately on the death of $\mathrm{J}_{\mathrm{ohn}}$. It was reissued again after the withdrawal of Louis. So long as William Marshal lived, it is likely, on a priori grounds, that government would be carried on in harmony with the spirit as well as the letter of the Charter, and we know of nothing to the contrary. The first difficulty seems to have occurred in 1223, and the incident in a way strikes the keynote of the reign. According to the account of Roger of Wendover, ${ }^{4}$ in January, in what seems to have been an adjourned meeting of the Christmas curia regis, the archbishop and others demanded the confirmation of the charters. What special reason there was for this demand at the time is not shown, but it would seem from other things that the financial 4 Ed. Coxe, IV. 83; M. Par., III. 75. 


\section{ORIGIN OF THE ENGLISH CONSTITUTION}

difficulties of carrying on the government were beginning to be felt by those in authority. ${ }^{5}$ They now opposed the demand of the archbishop, and William Brewer, one of them, speaking probably for them and in the name of the king, declared that the grant of liberties, having been extorted by force, ought not to be observed. This excited the anger of the archbishop and he said: "William, if you love the king, you will not disturb the peace of the kingdom." Then the king, seeing how greatly the archbishop was moved, declared that the oath which had been taken "to all those liberties" must be kept.

Henry III. at the time of this occurrence was in his sixteenth year. He was probably already beginning to take an interest in public affairs and very possibly had begun to show those personal characteristics which made the financial problems of his reign unnecessarily difficult. However this may be, this, his first recorded public act of his own, is strictly typical of his whole history. The confirmation of the

${ }^{5}$ See the letter of Honorius III. to Pandulph of May 26, 1220, Shirley, Royal Letters, I. 535: non sine causa miramur quod nunc carissimus in Christo filius noster Henricus, rex Anglorum illustris, cum, ratione minoris ætatis, pauciora quam sui prædecessores expendat, tanta dicitur inopia laborare, quod vix, vel nunquam regali sufficit magnificentiæ providere; quare gravis ipsi et tali regno potest imminere jactura. On May 18, 1219, Pandulph wrote to Ralph Neville to pay out none of the money coming into the Exchequer, cum, sicut bene novisti, dominus rex multis sit debitis oneratus, Shirley, Royal Letters, I. 120. On the date of this letter see F. M. Powicke, E. H. R., XXIII. 229. Evidence of the king's poverty during the period might be multiplied. See especially the formal acknowledgment of a rather long list of debts due to Pandulph, February 18, 1221, Cal. Pat. Rolls, $283-284$. 


\section{IMMEDIATE RESULTS OF MAGNA CARTA}

Charter was demanded; those responsible for the government opposed the demand; their opposition was met by a threat of force; in fear of the consequences the king yielded. The tragedy of his father's reign made no more profound impression on the mind and policy of Charles II. than the insurrection and the Charter on the conduct of Henry III. ${ }^{6}$ This fact has hardly been sufficiently noted among the influences which shaped the events of this reign. It is not strange that so impressionable a nature as Henry's should have received, in the especially impressionable years of boyhood, so deep a bent toward caution, or have acquired so great a dread of the power of revolted barons. Certain it is that never in his reign was he willing to carry resistance to pressure beyond a certain point, or to dare civil war, unless the odds in his favour were overwhelming. It is a special characteristic of the reign that, when the barons were united, the king yielded and what they demanded was done. It is in this sense that the incident of 1223 gives us the keynote of the reign. The only element which we cannot specify to make the case complete is the abuse which led to the demand for the Charter. But these at least are typical: the

6 Roger of Wendover (ed. Coxe), IV. 269; 1 \%. Par., V. 137, 339, 569; and the references in note 10.

7 It would seem as if the financial necessities of the government were the most reasonable explanation of the efforts which were made during this period to call in, earlier than strict right allowed, the castles, domains and escheats, which had been allowed to remain in the hands of those to whom John had committed them, or which had been granted anew 
demand was made; it was at first resisted; the pressure increased and developed into a threat of force; and the king yielded.

If, however, there was a confirmation in 1223, we now know nothing of it. In 1225 the Charter was not merely confirmed; it was resissued, with only verbal changes from the reissue of $121 \%$, unless the change in the preamble be thought more important, and in this form it became the Great Charter of English law. The case of that year is a simple one. The great council was asked for an extraordinary tax. The barons demanded a reissue of the Charter, as a

during the minority. On these and the efforts to recover them, see G. J. Turner, Trans. Royal Hist. Soc., third series, I. 205-262. It was to aid in this process apparently that the pope was induced, in April of this year, to declare the king of age. The only reason which he gives for his act, which he seems to recognize as premature, is lest arrangements which had been intended for the king's benefit should become disadvantages. See Shirley, I. 430, and cf. M. Par., VI. 69. The point is eren more clearly stated in the letter of May 26, 1220, Shirley, I. 535: quidam eorum [the prelates] non quæ regis, sed quæ sua sunt illaudabili ariditate captantes, castra, maneria et villas et alia demania ejus improbe usurparunt et detinent usurpata, in evidentem ejusdem regis injuriam et jacturam, occasionem frivolam prætendendo, quod ea servare volunt usque ad plenam regis xtatem; ut sic ipsis, invito domino, rem contrectantibus alienam, et in bonis regiis debacchantibus, interim rex mendicet. Towards the end of the year 1223, the effort led to the most formidable resistance which it excited, the insurrection of the earl of Chester and his supporters. It is possible that the financial needs of the government may have led it to stretch the law in other directions, but this is mere conjecture. Magna Carta must anyway greatly have hampered the regency in the free expansion of the revenue which would have been possible, if the methods of John could have been continued. The omission of c. 12 gave no freer hand. Clause 44 of the Charter of $121 \%$, with the interpretation which the men of the time would certainly give it under the influence of the original Charter and the insurrection, accomplished all that was intended by c. 12. Next to the fundamental principle which 
condition of their consent, because the king had been declared of age and certain of the grants made in his name during the minority had been already annulled. The Charter does not seem to have been considered to be among the concessions affected by the minority, but it was evidently thought to be an important enough matter to justify this precaution.

It has been supposed that in $\mathbf{1 2 2 7}$, when Henry in form took the government into his own hands, the Great Charter was annulled, and that, from this date to its next formal confirmation in $\mathbf{1 2 3 7}$, it was not in force. The idea is, however, due to a misapprehension, as has been clearly shown by an analysis of the evidence of 1227, and as is perhaps shown also by what look like attempts on the part of the pope to annul the Charter between 1230 and $1237 . .^{8}$ In form

the Charter transferred from feudalism to the modern constitution, its great service was to emphasize so profoundly the feudal principle of consent to extraordinary taxation that for three quarters of a century no one ventured to disregard it. But both Henry III. and Edward I., from their point of view, may be excused for not recognizing the beauties of this principle. Looked at in this way the Charter was certainly "reactionary"; it was a "stumbling block" in the way of the formation of the kind of constitution which would probably have come into existence without it.

8 See the careful study of what took place in 1227 by G. J. Turner, Select Pleas of the Forest, Selden Soc., XIII. p. xcix. As to the papal intention, a comparison of the bull of February 20, 1238, Rymer, I. 234, with that of January 10, 1233, Shirley, I. 551, suggests at least that the Great Charter was among the grants intended to be revoked. See Bliss, Calendar of Papal Documents, I. 148 (June 21, 1235), and M. Par., III. 382,368 . Perhaps by his denial recorded on p. 368 the king may have meant that it was not intended to include Magna Carta, and see the third letter of the pope to the legate Otto, dated February 20, 1238, Bliss, I. 167, and also pp. 224, 225 (1246). 


\section{ORIGIN OF THE ENGLISH CONSTITUTION}

at least, the Charter was in force throughout the entire reign, binding alike on king, courts and barons.

With 1227 the troubles of the reign began and they were continuous and consistent in character, despite some variety of detail, for nearly forty years. They were due, as is well known, to the character of the king. But Henry was not intentionally a bad king. In moral conduct, except when his financial difficulties led him to acts of meanness, he was greatly superior to his father. He intended to rule well and he thought of himself as a good and wise sovereign. He was jealous of his power. He knew there was danger to it in the air, though he did not understand the form in which the danger threatened, and he was determined to keep it in exercise himself, and to preserve it whole. Nor was his chief deficiency weakness of will, as was perhaps the case with Stephen, the king with whom he is most nearly to be compared. A more serious defect, in the crisis through which he was called to carry the royal power, was his weakness of intellect. This is seen not so much in that he did not understand his own time. Many rulers fail there. Rather he could not see the meaning or tendency of single events. He was no judge of men. He did not know what to do in difficulties. His government was continually directed by others without his knowing it, and he never had a consistent policy for any length of time except under the influence of a stronger personality. Richard of Cornwall, who 
was an abler man, though no political genius, exercised at intervals a strong influence over the conduct of affairs, and it might have been fortunate for the English kingship if he could have acquired permanent authority behind the throne. $\mathrm{He}$ was not the type of man, however, toward whom Henry inclined; it looks at times as if he felt some superiority in Richard and was jealous of him; at any rate during almost the whole of the reign the control of king and government was in the hands of inferior and more selfish men. It may be that Henry vaguely felt, as his father had clearly done, that his best support against his own baronage would be found in foreigners who should owe everything to him and who would naturally stand in opposition to the native aristocracy. Something could be said for such a policy if consistently directed by a strong and able king, but in the case of Henry it meant the exploitation of England by successive sets of utterly selfish foreigners who lacked wisdom of their own to see the tendency of events, or properly to identify the king's cause with theirs. They did not hesitate to endanger England's interests in France for their own ends, and they had no defense to offer against a like abuse of the king's weakness by the pope.

Such a reign, guided by no strong will, or dominating policy, was opportunity. It was a period open to be shaped by whatever influences might prove strong${ }^{9}$ See Ann. Wykes, p. 118; M. Par., III. 532; IV. 11; V. 73. 


\section{ORIGIN OF THE ENGLISH CONSTITUTION}

est among the cross currents of the time, and whatever the outcome of the age might have been, it would seem to us, in the absence of leadership, that such an outcome was the natural end towards which all things had drifted.

Strong among the influences in such a period would be the impression made by events which lay not far in the background of the past, upon the minds of those who were now to determine the course of things. The king was not more conscious of the meaning of the last years of his father's reign than were the barons. ${ }^{10}$ In 1237 many must have been living who had gone through the time of struggle for the Charter. Of the twenty-five, at least four still survived. Of the twenty-seven named in the preamble, at least six. ${ }^{11}$ Of these ten, six witnessed the confirmation in 1237. It would be very strange indeed if it were merely the

10 Roger of Wendover (ed. Coxe), IV. 295; M. Par., V. 360, 729, 732. See note 6.

11 These were, of the twenty-five, John de Lacy, Richard de Percy, Roger de Montbegon and Richard de Montfichet; of the twenty-sever, the bishops of Winchester, Bath, and Worcester, William earl Warenne, Hubert de Burgh and Matthew FitzHerbert. The list of those active in public affairs at both dates could be much extended. Of the witnesses of the confirmation of 123\%, the bishop of Durham was in 1215 bishop of Chichester and took an active part against the French; Bishop Grosseteste was then about forty years old; the earl of Ferrers witnessed John's charter for the church in November, 1214; Roger de la Zouche was one of those named as swearing to support the five and twenty barons, and William de Cantelupe as one of John's evil counsellors; William de Lancaster was captured by John in Rochester castle, and William de Ros, William Mauduit and Oliver de Vaux were among those excommunicated by name. Several of these were still living in 1244. 
Charter which men remembered, when it became necessary to demand of John's son the reform of abuses, and not also the general conditions which produced the Charter and of which it was to be the correction. When similar conditions returned, or what seemed to the actors in events similar conditions, it is natural that it was at first thought that a renewal of the Charter which had grown out of those conditions in the past would meet the case. It was only after some years that it was seen to be necessary to go farther in the direction which the Charter had pointed out.

The reign then, looked at from this point of view, leads to two results, or series of results: First, confirmations of Magna Carta, and second, experiments at further control of the sovereign which culminate in the Provisions of Oxford and the Barons' War.

Confirmations of this sort begin with that of 1237 . It must be understood that the reason and purpose of this confirmation was quite different from that of the reissue of 1225. That was demanded and granted on general principles merely, to make sure that the Charter was in force and not affected by the disabilities of a minor grantor. This was for a specific purpose, to hold in check a king who had proved ready to lend himself to many abuses and difficult to restrain. Already, in 1233, Richard Marshal, in a spirit worthy of his inheritance, had thought himself driven to an appeal to arms, premature and almost useless, though 
it gave an opportunity for the application of other means by which the king was brought to an appearance of reformation. It was a reformation, however, without a change of heart, and by 1237 the abuses complained of were as bad as ever and the character of Henry was somewhat better understood. ${ }^{12}$ Advantage was taken of the king's necessities and his request for a new tax, to demand a confirmation of the Charter which was granted in a special charter and accompanied with a solemn renewal by Archbishop Edmund of Stephen Langton's earlier excommunication of all who should offend against it. ${ }^{13}$

The demand for the Charter, however, was clearly, neither in 1237, nor at any later date in the reign, primarily a demand for its specific provisions. The abuses which were most bitterly complained of, Henry's dependence on foreigners, his neglect of his natural counsellors, a reckless squandering of money, were not directly aimed at in any of the clauses of Magna Carta. There is no evidence in this reign of any violation of its specific provisions which passes from the character of an individual grievance to con12 The barons seem to have been easily persuaded, howerer, to accept the king's promises, as compared with later times, and Matthew Paris, very likely writing some years after the event, appears not to have been unconscious of the fact. See III. 383.

13 The charter of confirmation is given in Ann. Texk., p. 103; Stubbs, S. C., p. 365 ; and see M. Par., IV. 186. On the excommunication, cf. M. Par., III. 382; IV. 366; V. 360; Epp. Grosseteste, p. 231; and Ann. Wykes, p. 83. Grosseteste, who certainly wrote very soon after the event, and who witnessed the parvam cartam of 1237, probably states accurately what occurred. 


\section{IMMEDIATE RESULTS OF MAGNA CARTA}

stitute a danger to the baronage as a whole. ${ }^{14}$ What was wanted was something different. It was to force the king to acknowledge that he was bound by certain obligations in his conduct of public affairs. ${ }^{15}$

It ought, I think, to be clear, if one reflects on the nature of the abuses, laid now and later to the king's charge, that a change was beginning which was the opening of a new era. All through the list the difference between Henry's case and John's is clear. Of wardship, marriage and the treatment of widows, it was not said that Henry was pushing royal rights beyond bounds to extort money to which he had no

14 It may be thought that the denial of trial by their peers to Richard Marshal and his supporters in 1233 approaches the point of danger. See $M$. Par., III. 247, 251; Bracton's $N$. B., case 857. Their case is, however, not wholly clear. See Vernon Harcourt, His Grace the Steward, pp. 276-280, with whom, however, I cannot entirely agree. It may also be thought that the frequent complaints by ecclesiastics of the violation of liberties supposed to be secured the church indicate dangerous infringements of the Charter; but analysis of their complaints does not show this to be the case. On the other hand, the statement in P. and M., I. 179, must not be understood to mean more than it says. It is there said: "The pages of the chroniclers are full of complaints that the terms of the charter are not observed. These complaints, when they become specific, usually refer to the articles which gave to the churches the right to elect their prelates." No doubt that is true. But it would not be correct to infer that interest in the Charter as a practical matter was confined to ecclesiastics or references to it to the chroniclers. It would be quite as accurate to say that they were confined to lawyers and law courts, for the evidences of their interest in it and their references to it are quite as numerous. An interesting instance is Bracton's $N$. $B$, pl. 1227, where the Charter is referred to as if it were a binding statute which might determine the decision if it had anything to say on the question before the court.

15 This is true also of practically all the demands for the confirmation of Magna Carta after this date. They express not so much a desire that specific provisions of the Charter should be reaffirmed, though there is 


\section{ORIGIN OF THE ENGLISH CONSTITUTION}

claim; it was said that he was using these rights to provide for foreign favorites at the expense of his own natural subjects. Of taxation it was not said that he was demanding illegal payments, but that sums which we know to have been obtained properly according to the law, disappeared in a bottomless gulf without advantage to England. In matters that concern the courts, it is clear that the requirements of the Charter were in the main regarded, and complaints had shifted into a new field and affected the interests of the royal courts only indirectly. Of the miscellaneous provisions of the Charter the general fact is the same. ${ }^{16}$ The really serious complaints do not concern them. In addition one thing of which the son is constantly accused was not alleged against

evidence in plenty that many of these were treated constantly as living law, as a desire to get the king's acknowledgment in general that he was bound by the law. They constitute a definite line along which the fundamental idea of the Charter was carried through the formative age of the constitution and they ceased only in the fifteenth century, when it had come to be no longer a matter of dispute that there was a certain body of law which bound the king, or in other words when something which may be fairly called, in almost a modern sense, the constitutional monarchy, had been established. These confirmations of the Charter were certainly no mere form and they were not necessary because "it failed to do its work" (Jenks, l. c., p. 271). They were necessary because the kings were constantly devising new methods of escaping their obligations, and because there were constantly arising new interests and issues in which the king must be bound to serve the nation.

16 See the Petition of the Barons of 1258, Stubbs, S. C., p. 382, for complaints of the violation of a number of the provisions of the Charter. It is evident, however, that these complaints played a very small part in producing the revolution. The real abuses which moved the barons to action were the newer ones, and it was at these that the Provisions of Oxford were aimed. 
the father at all-the neglect of his natural counsellors. It is a complaint typical of the transition, and involves in its brief statement cause and consequence of the crisis. It says : this king does not himself govern, the government is in the hands of his council which exercises his prerogatives for him and determines all that is done; his counsellors are now foreigners who have no regard for the interests of England or Englishmen but sacrifice both for their own selfish ends; foreigners have no right to hold such a position, the right belongs by nature to the baronage of England; if the king's natural counsellors were conducting the government, the abuses would cease and the interests of England and Englishmen would be conserved. There was no room for such reasoning in the case of John. It would have been absurd to assert that anyone but himself was responsible for his tyranny, or to believe that a change of counsellors would bring it to an end. But this and not the violation of particular provisions of the law was the great difficulty with Henry.

The difference, however, was much deeper than a difference in personal character between father and son. It was the beginning of a difference between two ages of history, two eras of civilization. Translated into other terms this complaint meant: in the conduct of public affairs there is something which ought to be regarded besides the king, the king's interests and the king's friends; something which it 


\section{ORIGIN OF THE ENGLISH CONSTITUTION}

is the plain duty of the king and his counsellors to regard. Over against the king's interests, stand the interests of the land and of those who have a stake in its prosperity, as something which may be different from his, something which the king may be tempted to sacrifice for what he selfishly desires. It is not possible to say "the nation" yet, as the modern man uses the term, but this is the idea and the fact which was really coming to birth. Such a conception was foreign to the feudal age, but feudalism, in its constitutional aspects, in the conception of the state logically involved in it, was rapidly coming to an end. The old ways of doing things, judicial, legislative, financial, military, were all giving way before the new. The emphasis which daily life placed on its own details was also changing. To the barons of 1215 the writ Præcipe and what it stood for seemed a vital matter. Before the close of Henry's reign, their descendants had come to care little about it, and indeed were letting slip from their hands with seeming indifference the really essential elements of all private jurisdiction which were feudal proper in character, and not financial or manorial merely. ${ }^{17}$ Men

17 See the reference to Hengham Magna, c. 3, from P. and M., I. 588. Such a principle regarding court service as that laid down in the Provisions of Westminster, c. 1 (Stubbs, S. C., p. 401) (Statute of Marlborough, c. 9), runs squarely counter to the practice of feudalism at its height and indicates a notable decline in feudal feeling. The attitude of the lawyers of the middle of the century towards court service in the baronial courts is well enough known. See Maitland, Man. Courts, xlvii. ff. It should be noticed that pl. 531 of Bracton's $N$. B. does 


\section{IMMEDIATE RESULTS OF MAGNA CARTA}

were of course unconscious of any change. They could not have put into words in 1237 the ideas which were struggling for expression in the things they were doing. Nor could they even in 1264. When they tried they fell back upon the formulæ of ancient speculation, or upon notions embodied in the feudalism they were destroying. ${ }^{18}$ None the less they were really giving first and faint expression in their acts to modern conceptions of the balanced rights and obligations of government and nation which seem to us the commonplaces of politics.

If it had been possible for them to formulate their ideas clearly, they would not have been satisfied in the crisis of 1237 to demand merely the confirmation of the Charter of 1225. There would have been

not support the principle that if the lord "wishes that his tenant should do suit from three weeks to three weeks, he must expressly bargain for it." The tenant in the case had been enfeoffed to hold by the service of a rent payment pro omni servitio which would have exempted him from ordinary court service at any period in the history of feudalism. The same is true of the case of B. in pl. 655. L.'s case is not so clear, but the jury holds that it is covered by their verdict regarding B. A clear case to the point would be one where an ordinary charter of enfeoffment with no exemptions and no specification of court service is held to excuse from suit of court. There can be no doubt, however, but that the principle is established in the middle portion of the thirteenth century. Bearing indirectly upon the point, as illustrating the general frame of mind, and interesting in itself, is the attitude of Hugh Bigod, the baron's justiciar, towards baronial and municipal liberties. See Ann. Dunst., p. 211-213; Liber de Antiquis Legibus (Camden Soc.), pp. 39-41; Flores Hist., II. 427. Bearing more directly upon the statement of the text is the apparent general indifference with regard to the development of forms of writs by which c. 34 of Magna Carta was rendered practically void.

${ }^{13}$ See note at the end of the chapter (p. 311). 


\section{ORIGIN OF THE ENGLISH CONSTITUTION}

added a more definite statement of the king's obligation to be bound in his conduct by the interests of the community. Their experience did not yet reach to such a conclusion. For us, however, as students of history, it is indispensable to understand that it was in its specific provisions only that Magna Carta did not apply. In the great principle on which it rested, its application to the crisis was perfect. There was in it a recognized body of right which the king was bound to respect. This law had for its object to protect the interests of the ruled against the selfishness and tyranny of the ruler. If the ruler could not otherwise be brought to observe it, force was a legal recourse and the temporary suspension of the king from ruling. All this was legitimately involved in Magna Carta, even as reissued in 1225. To the men of 1237 , Magna Carta would stand out from all the past as the legal document giving most clear expression to this principle. This it was, vaguely realized, which was sought in it. It bound the king morally and legally and with all the sanctions of religion, in principle to conduct the government in the interest of his subjects. If ideas had widened somewhat, if the community of the governed was now felt to be larger than in 1215, the principle had not changed. If the king would do this, if he would be true to the spirit as well as to the letter of the Charter, the troubles of the kingdom would cease. Not understanding the nature of their demand, they did not perceive that [294] 
they were taking the first step towards adding to the formal requirements of the Charter a new and broader one, that the government must be managed in the interests of the governed. I think they were entirely right in feeling that this was properly implied in Magna Carta, but when the time came that the character of this requirement could be understood, a whole age had passed away, and a new civilization had possession of the world.

The confirmation of the Charter did not mend matters. Some part of what the barons called abuses was inevitable. The economic revolution which had troubled John did not close with his death, and there would have been complaint of the expenses of government under the most economical of kings. ${ }^{19}$ But

19 What had started the whole revolutionary movement at the beginning of the thirteenth century was indeed the breakdown of the feudal system as a source of government supply. In addition to the economic revolution, the increasing amount and complexity of business had to be reckoned with. This showed itself on one side in the rapid development of the royal courts, and on another in the increasing expenses of the government, which it was no longer possible to meet with the ordinary sources of revenue. To the men of the time the efforts of the kings tc raise money were signs and proofs of their complete depravity, and there is no doubt but that the difficulties of the case were complicated through more than half the century by bad government; but the best king that ever reigned, had his lines fallen in England in the thirteenth century, would have been forced to resort to much the same expedients. The French monarchy had to face this difficulty later and less suddenly than the English, but it made use of practically the same means to meet it, and experienced practically the same opposition, though this was for special reasons less united and less intelligent. The expedients to which the papacy was obliged to resort during the reign of Henry III. in order to obtain an adequate revenue were due to the operation of the same general causes. 
Henry had no mind to any sort of reform. He no more understood the situation than did the barons, and he firmly believed that he was quite within his rights in choosing as counsellors whom he pleased, as indeed he was according to the letter of the law. ${ }^{20}$ Within a few years the barons began to perceive that Magna Carta was insufficient. It did not enforce itself.

In saying that in the reign of Henry III. it was "seen that the Charter was not enough," Professor Jenks is quite right. ${ }^{21}$ But it does not follow that in consequence the barons were led to attempt "an entire break with the past." That is to overlook the fact that in the reign of Henry III. exactly the same problem arose as in the reign of John. It was not the problem of getting the king to acknowledge the existence of a body of law which he was bound to observe. Both kings did that, Henry repeatedly. It was the problem of how to compel the king to keep the law when he persistently refused to do so. ${ }^{22}$ This

${ }^{20}$ The peculiar glory of the English Constitution is indicated in saying that precisely the same thing is true of King George V. today, but that he does not exercise the right.

21 But the same thing could be said of the Charter of 1215 with only slightly less accuracy. It would not have enforced itself in the long run, even if clause $6 \mathrm{I}$ had been retained. The principle that the king is bound by a definite body of law would never have led to anything without the established practice of coercion, to be exercised anew from age to age as changed conditions brought on new crises, unprovided for in the experience of the past. It is the complete transfer of sovereignty to Parliament which has eliminated the king from the constitutional struggles of modern times and essentially changed their character. 22 "Erat videre dolorem in populo, quia nesciebant prælati vel magnates 
problem the barons of the middle of the century met as it had been met a generation earlier. They attempted no break with the past. In the next case to be noted, in 1244, as in 1258, they copied its model and built on the lines it had established, and, though the particular thing they sought to do was slightly different, and their machinery was more developed, their purpose was identical, the suspension of the king from office in certain particulars for the protection of the community. This purpose was a little more clearly perceived; it was a little more widely applied; and the machinery by which it was to be carried out had been somewhat improved..$^{23}$ But they found their starting point in clause 61 and they made no change which touched essentially principle or method, no

quo nodo suum Prothea, scilicet regem, tenerent, etiamsi omnia hæc concederet, quia in omnibus metas transgreditur veritatis," $M$. Par., V. 494 (1255). The statement is repeated in the account of the May meeting of 1258 as explanation of the adjournment till June, with the addition of the phrase "quia arduum fuerat negotium et difficile," ibid., V. 689.

23 The improvement of machinery in the proposed arrangement of 1244, as compared with that of 1215 , consists in the fact that the commission of the barons was not to take into its own hands a function of the king's for exercise in special cases, but that it was to appoint the great officers of the crown who were to exercise royal powers in the government as a whole and so provide for a more complete suspension of the king. While this arrangement is entirely in line with that of 1215, the exact suggestion of the appointment of the officers probably came from another source, perhaps from expedients of the minority, perhaps from the abuse of the great seal complained of by the barons. I think it possible to do something more than has yet been done towards working out the origin of this assumption of the right of appointment. In stating the relationship between the experiments of 1244 and 1258, I am following what may be called the orthodox opinion. See Stubbs, II. Sec. 175; and Tout, Polit. Hist. of Engl., III. 66. 


\section{ORIGIN OF THE ENGLISH CONSTITUTION}

change so vital that the experience of the intervening time may not easily account for it as a natural growth. Nor should it be forgotten that one of the twentyfive appointed under that clause was one of the commission of twelve chosen in 1244 to put into form the virtual suspension of the king. ${ }^{24}$ We do not know that this arrangement, which has been called a paper constitution, ever actually went into force; the king refused to accept it, but in 1258 a real constitution was formed, more or less completely in operation for many months.

Looked at as a work of the thirteenth century, the Provisions of Oxford are a great improvement on clause 61 of Magna Carta, both in the object to be accomplished and in the machinery for doing it. Such advance in purpose and character was forced on the barons by the situation. What they had to do now was not to provide for the correcting of a number of specific abuses, of a generally uniform character, which might be done by assuming a single prerogative of the king's, as in the court created by clause 61 . They needed rather to provide for the whole government, to take it out of the hands of an incompetent king, who could not be reformed, and conduct it in

$24 \mathrm{M}$. Par., IV. 362-368. It is plain from the character of the last part of the document recorded by Matthew Paris that it is a memorandum merely, and from the reference to the nova carta at its beginning that it would finally have stood to the completed constitution which it was proposed to form in much the same relation as that of the Articles of the Barons to Magna Carta. 


\section{IMMEDIATE RESULTS OF MAGNA CARTA}

the interests of England. A purpose so much larger compelled machinery on a larger scale and of a broader scope. But it was the same in type. Clause 61 provided for the exercise by the court of twentyfive of one of the most important of the king's prerogatives, if he refused to use it himself to reform some definite abuse. It provided further, if this first step proved unavailing, for the temporary suspension of the king by moving war against him. To those of the barons who remained faithful to the Charter in the struggle which followed John's repudiation of it, it seemed necessary to remove him permanently and to put another sovereign in his place. This extreme step was never contemplated by the Charter. It was not quite in harmony with the spirit of the long process by which the constitution was made, or, if it cannot be denied that it was a logical inference from it, it was going to an extreme almost never called for. If we pass over the case of John, such a step proved really necessary but once, in 1688 , and then not for the creation, but for the preservation, of the constitution. ${ }^{25}$ In this particular the Provisions of Oxford

${ }^{25}$ Appeal to force was necessary in the case of Richard II. and of Charles I. But the earlier reign of Richard shows conclusively that the extreme step taken was not necessary against him, and the same thing is highly probable of Charles I. Edward II.'s deposition was not in reality a constitutional case at all, though it was necessary to try to make it seem so, and though it did serve as a precedent for later action in cases that were more truly in the line of constitutional derelopment. In truth, however, the right of deposition and not that of electing the king was the essential one upon which the security of the constitution 


\section{ORIGIN OF THE ENGLISH CONSTITUTION}

were exactly in line with the intention of clause 61 , with what it was hoped that clause would accomplish, but they show a great advance over it. Like the modern constitution, they would make civil war and the deposition of the sovereign impossible, if they were put fully into operation, ${ }^{26}$ and the object of the machinery set up by clause 61 really was to make it possible to avoid an appeal to arms.

If one will compare carefully in the object sought and in the intended details of operation when put into

depended. The old Teutonic election was as empty a form in England as in France. The right of choosing the successor of a deposed king was a logical but unessential result of the right of deposition. What was absolutely necessary to the continued existence of the constitution was the right of deposing a king already in possession of the throne, or of bolding this fate in reserve as a means of coercion. That the right of election received later so much more emphasis than the right from which it was derived was due to accidents of the situation at the accession of one dynasty after another, while few occasions arose for the exercise of the more fundamental right. It would be of course impossible that the right of deposition should be formally embodied in the public law of any state not on the verge of dissolution. See the account of this period in Plehn's Matheus Parisiensis-a very interesting discussion, but too theoretical and too strongly influenced by apparent analogies in the institutional history of Germany. The treatment of the question of election to the crown in Roessler's Kaiserin Matilda agrees better with the facts.

26 No real similarity between the Provisions of Oxford and the present constitution must be supposed. The only historical connection between them is that the Provisions were one stage in the development, clarifying and enforcement of the idea that the king is bound by the law. The final constitution was built on no detail of the scheme. To say that the responsibility of the officers of the crown to the great council, which they established, foreshadows the ministerial responsibility of today, is to use language which is permissible rhetorically, but it is not the language of science. One might as well say with Hallam (Middle Ages, chapter VIII. pt. 2), that the deposition of Longchamp in 1191 is "the 
force, clause 61 , the arrangement of 1244, and the Provisions of Oxford, I believe it will be found impossible to deny that they are all of one piece, all framed on one model, to solve essentially the same problem. They show only those changes which the passage of a generation, and the naturally changing situation required. The plan of $\mathbf{1 2 4 4}$ is the intermediary, the connecting link, between Magna Carta and the Provisions of Oxford. It may be fairly called this because it stands out most prominently, and is the most complete proposal between these two so far as we know. It would perhaps be more accurate to say that there are evidences earlier that the plan of temporarily

earliest authority for a leading principle of our constitution, the responsibility of ministers to Parliament." There is no line which runs from the earlier fact to the later. The two facts grew out of the independent conditions of two different civilizations. There was no Parliament to enforce the Provisions of Oxford, only the feudal curia regis; they could draw strength from no nation, only from a feudal class. One civilization was indeed beginning to give way to the other, but it was the old which still had possession of the field. In ultimate purpose the constitution of 1258 was premature; in process it was already almost obsolete. It is also as unfair to criticise the framers of the Provisions of Oxford for not expressing ideas beyond their political horizon, as it is to hold the barons of 1215 accountable for the same defect. The objection most often made against their scheme of government is that it established an oligarchy and made no provision for the representation of the commons. But I believe that this idea was still impossible in 1258. The use of the word commun, as in the Provisions, Stubbs, S.C., p. 388, which is correctly enough translated "commonalty," is of occasional occurrence in the documents of the time, but I do not believe that we should be right in giving to it any more specific meaning than we should to the phrase communitas regni. See communam regni, M. Par., Hist. Angl., III. 51. It meant primarily the barons, but it was beginning to mean in a secondary sense the whole body which we should call the nation, or such portion of it as had any interest in public affairs, for whom the barons

[301 ] 
resting in another the prerogatives, or a prerogative, of the king, as a means of holding him in check, had not been forgotten, and that between 1244 and 1258 there are further instances of the demand of some such scheme, or of the bringing of it forward as a suggestion or a threat. ${ }^{27}$

By 1258 not merely had abuses, financial and other, grown to be intolerable, but circumstances favoured decisive action as they had not before. In the first place Earl Richard, who might have stood between the monarchy and the complete carrying out of any revolutionary scheme, was out of the country. ${ }^{28}$ Again

were acting not because they thought of themselves as representatives, for that idea also was still in the future, but because they were the only portion of the communitas regni yet accustomed to take part in the operation of government. In saying this I do not overlook the fact that four years earlier, in 1254, knights had been elected in the counties to inform the council of the local decision regarding a proposed grant of money to the king, but on this incident see the discussion in chapter VII. If the opinion I hare expressed in the present note is proved to be incorrect, it will be done, I think, by obtaining more light on the proceedings which led up to the Provisions of Westminster, and a clearer understanding of what that document itself implies in relation to the whole crisis. It is greatly to be regretted that we have no statement of the reasons which led Simon de Montfort to disagree with the other barons about the Provisions of Oxford, and to promise his adherence to them with reluctance. They might be instructive upon this point. See Prothero, Simon de Montfort, p. 200, citing the Chronicon de Lanercost, p. 67, and Bémont, Simon de Montfort, citing a translation of William of Nangis in Bouquet, Hist. de Fr., XXIII. 17, cf. William de Nangis, Gesta Sancti Ludovici, Bouquet, XX. 414, and Chron. (ed. Soc. Hist. de Fr.), I. 224, and n. 3.

27 In any detailed constitutional history of the period, these cases, especially those of $1237,1248,1249$, and 1255 , should receive careful attention. 28 There is some evidence to justify the opinion that Richard was quite willing to push his opposition to the king to a certain point, but that 
the great body of the higher baronage was united on one side, against the king and his foreign favourites, and had with it the strong support of the minor barons. Finally, perhaps alone sufficient to explain the result, the opposition to the king had found what it had lacked heretofore, adequate leadership. ${ }^{29}$ It is hardly possible to call Simon de Montfort a political genius. To me at least he seems to have mismanaged, almost grossly, what he had to do both in Gascony and in England. But he had certain qualities and elements of character peculiarly demanded in the leader of a revolution against established government. His most marked trait is the most necessary in such a leader, his immense power of will, his inflexible determination. Imperious his will was, overbearing his own judgment as well as all criticism and opposition of others, impolitic to a degree, but it was unhesitating and unyielding, it took no account of odds or danger, it saw the one result to be reached and neither heaven nor hell should block the way. To this must be added a strong sympathy with justice, vigor of action, more than the average of military skill, and, I think I am

when measures began to seem revolutionary, or to affect the royal prerogative, he drew back. His defection from the cause of Richard Marshal in 1233 was a serious blow to that attempt to force a reformation, and see M. Par., Hist. Angl., III. 51, n. 1, and Chron. Maj., V. 514. ${ }^{29}$ The leadership of Simon de Montfort in the general opposition which leads to the Provisions of Oxford does not seem to me to be rendered doubtful by the fact that he did not agree with the final arrangements adopted. It seems clear that his objection was because they did not go far enough. See the references in note 26 .

[303 ] 
not wrong, the vaulting ambition of Macbeth. Perhaps it needed Simon de Montfort's personal grievances against the king to put him at the head of a revolution, but once there he threw into it the whole strength of a nature powerful and gifted, but not always wise, and possibly not always sincere.

It is not my purpose to discuss here the details of the Provisions of Oxford, nor, what stands more in need of discussion, the relation to them of the Provisions of Westminster. The scheme was an elaborate one. It sequestered the king entirely from the government. It may indeed be said of it that it put the kingship into commission, though that was an idea not possible to the time. All the operations of the state, financial, administrative, judicial, legislative, were to be carried on under a direct responsibility to the great council. A series of commissions and appointed officers, including a new king's council, was to conduct the government, and the great council rested its supervising authority in a committee, practically to be in continuous session. The king was not deposed. In form all prerogatives were still exercised by him, all writs and royal letters were issued in name by him, even when he was a helpless prisoner in the hands of the earl of Leicester. The Provisions of Oxford set up machinery to take the government out of the hands of a king who persistently refused to administer it in the interests of the country, without the necessity of deposing him, or of bringing on 


\section{IMMEDIATE RESULTS OF MAGNA CARTA}

civil war. ${ }^{39}$ This was clause 61 of Magna Carta over again more broadly framed and more explicitly stated.

To recapitulate: the Provisions of Oxford find their origin in Magna Carta and rest directly upon it. They draw from it their underlying idea, the right to coerce the king; their form, commissions assuming prerogatives of the king and so far forth suspending him from office; and their general purpose, to secure the rights of the community against a king who persistently refused to regard them. They are connected with it by a continuous line both of confirmations of the Charter and of suggestions and experiments in the way of similar machinery.

But the Provisions show a great advance. They are more elaborate in machinery, wider in scope and logically more complete. But more important still it was much less their object to enforce specific rights of individuals which could be drawn up in an exact list than was that of the Charter. Their object was rather to enforce the general right of the community of the ruled to good government, administered by natural, as they. said, that is, national officers. The document in which they are embodied has more nearly the nature and form of a written constitution. This is the great advance. This it is which makes the Provisions of Oxford the first and longest step in the

30 War was threatened against those who should oppose themselves to the Provisions. See the king's writ in English. Rymer, I. 378; Stubbs, S. C., p. 396, and compare Ann. Wykes, p. 119, for the royalist view. 


\section{ORIGIN OF THE ENGLISH CONSTITUTION}

transformation of the feudal principles of Magna Carta into the guiding principles of constitutional growth. The Provisions of Oxford do look towards the future more clearly than the Great Charter, but not because they are a break with the past, not because they are a new beginning, rather because they are building from foundation stones of the old on farther into the walls of the final structure.

The Barons' War which followed was in principle the same as that which followed John's repudiation of the Charter. The diffidatio which the barons issued before beginning their campaign in 1263, with its salva persona regis, regine, et liberorum suorum, seems based on the text of clause $61 .^{31}$ Simon de Montfort's formulation of the right of insurrection, in the confirmation of the charters which was issued as one of the conditions of the release of Edward from his obligations as hostage for his father, in March, 1265 , is of especial interest. The document is a peculiar one among confirmations. ${ }^{32}$ It was made to suit the occasion in other ways than that which gives it its common name, but its documentary connection with Magna Carta is clear enough. ${ }^{33}$ In the end the barons were defeated and the Provisions overthrown, but they left as their legacy to the future the two prin31 See Liber de Antiquis Legibus, p. 53.

32 Liceat omnibus de regno nostro contra nos insurgere. Stubbs, $S$. C., p. 416.

33 See for example the phrase: quo facto nobis sicut prius intendentes existant. Stubbs, S. C., p. 417. 


\section{IMMEDIATE RESULTS OF MAGNA CARTA}

ciples on which Magna Carta rested, which might have perished without their renewed emphasis. ${ }^{34}$

The reign of Edward I. saw no repetition of the experiment of 1258. Edward was a king against whom such an expedient was unnecessary, as it would have been impossible. The reign was occupied with the equally important effort to take the first steps in the constitution of Parliament. But in one particular the reign carried forward the line of development represented by the Provisions of Oxford. In 1297 Edward was forced, by means the same as those employed so many times against his father, to confirm Magna Carta, and to go a step farther. The confirmation included what was really an addition to the Charter, in truth a restoration to it of clause 12 which had been dropped in 1216, so thought of and intended at the time, ${ }^{35}$ and so treated in the future. It was

34 One result of the reign of Henry III. ought not to be overlooked, though perhaps it belongs rather to political than to constitutional history. That is the formation of a distinct, and almost in our sense of the word an organized party of opposition which proved to have a continuous, or almost continuous, history. Until it was absorbed into the later Parliamentary opposition, this party was baronial, and often more partisan and selfish than broadly patriotic, but it was the instrument by which the work of continuing the tradition of Magna Carta was accomplished until Parliament had reached a stage of development which enabled it to assume the task.

35 The petition of the barons which preceded the confirmation bears in the chronicle of Walter of Hemingburgh (ed. Hamilton), II. 152, the title Articuli inserti in Magna Carta, and even if we cannot be sure that these are more than the words of this contemporary and fairly accurate chronicler, they indicate to some extent the feeling about the effect of what was then done. The insertion of the main point of the petition about taxation in the formal confirmation which followed makes it dis- 


\section{ORIGIN OF THE ENGLISH CONSTITUTION}

more, however, than a restoration of clause 12 . It was a restatement of it in such form as to include not merely the specific taxation of the feudal age, but so also as to affirm the broad principle of consent to all taxation, not resting on the basis of feudal property. It is clause 12, that is, the principle of the feudal law concerning extraordinary taxation, broadened out to cover, in intention at least, the new methods of taxation of the modern state. This enlargement of the law that binds the king, was the initial point of all the great increase of that law during the next century, and it was, as I have said, forced from the king in the same way that similar concessions were forced from Henry III. It belongs in other words not in the line of the Parliamentary development of the constitution as that is seen later, but in the line of the origin of the constitution as that ran through the thirteenth century. This line is continued by the Lords Ordainers in 1310, but the connexion of their work with the Provisions of Oxford needs no emphasis here. ${ }^{36}$

It is to be said of all such schemes, however, that they are revolutionary when looked at from the point of view of the ordinary law, ${ }^{37}$ the law as administered in the courts and found in the books of the law writers,

tinctly an addition to the Charter, that is, to the body of law which the king must observe.

36 Stubbs, Sec. 251 ; Tout, Polit. Hist. of Engl., III. 244, 248.

${ }^{37}$ Louis IX. was quite right in his decision annulling the Provisions of Oxford by the Mise of Amiens, for this was the only point of view from which he could look at the question. He did not see the inconsistency of this part of his decision with that maintaining Magna Carta in force, 
so far at least as these do not touch upon questions of the constitution. ${ }^{38}$ In this field the king was then, as he is today, above the law. He was not subject to its processes; he was not bound by its provisions. A Henry III. might be guilty of fraud or forgery with impunity. This is the ever present contradiction of English history, but it is also the secret of the making

as the barons appear to have done, or some of their supporters at least somewhat later. Ann. Worc., p. 448; Chron. de Bellis (ed. Halliwell), p. 17.

38 They nearly all do to some extent touch upon the constitution, and then this fundamental contradiction is apt to occur more or less plainly. In the case of Bracton, it has excited considerable discussion, but, except for its early date, it should occasion no more remark than in the case of Blackstone. See Bracton's N. B., I. 29-33; McIlwain, The High Court of Parliament, pp. 101-103. It should not be overlooked that the probably apocryphal passage in certain Bracton MSS., in which the right of the curia to hold in check the king is stated in the most extreme terms, is certainly of the thirteenth century, and probably earlier than 1290. Bracton, f. 34, ed. Twiss, I. 268; cf. Maitland, Braeton's N. B., I. 30-33. See Blackstone, Bk. I., chapters VI. and VII. With the clarifying of ideas and the settling of many questions of the application of ideas in practice, which has taken place in a hundred and fifty years, it is probable that to the modern student Blackstone seems to emphasize the limited at the expense of the absolute aspect of the monarchy, more clearly than he did to the young Prince George when he read the Commentaries in manuscript as a part of his education in the business of a king. The contrast in Blackstone is less sharp, less dogmatic, than in Bracton, in part because he deals with the two sides of the kingship in the same portion of his work, so that one naturally qualifies the other, and in part because at the middle of the eighteenth century the compound nature of royalty, its relation on one side to prerogative and on the other to the fundamental law of the state, was more clearly perceived. There is nothing in Blackstone, however, on either side which is not the logical development of what is to be found in Bracton. The clearest statement of the principle that the king is bound by the law, in the great series of English constitutional documents, is in the Bill of Rights of 1689, but it is also made clear in the articles drawn up against Richard II, at the time of his deposition in 1399. 


\section{ORIGIN OF THE ENGLISH CONSTITUTION}

of that unique constitution, most anomalous and inconsistent, but perhaps on that account most adaptable, of all time. It was by the working together of these two contradictory principles, the king is above the law, the king is subject to the law, that a monarchy, retained in form, preserving all that is useful in a monarchy, was transformed into a self-governing republic, politically democratic. 


\section{IMMEDIATE RESULTS OF MAGNA CARTA}

\section{Note A. The Argument for the Barons}

\section{(Page 293.)}

SEe the arguments of the Song of Lewes. In this contemporary poem the justification of the barons' conduct rests mainly on what may be called the theological or speculative argument, as that had been developed for instance by John of Salisbury. See Dunning, Political Theories, pp. 186-187; Poole, Medieval Thought, pp. 233-235; The Song of Lewes, ed. Kingsford, notes, pp. 113-118. The idea that the king is subject to the law is clearly enough expressed, but the law is not the law of the state, not constitutional law in our sense, but the divine law, natural equity and justice. In this sense it is that the barons do not enslave the king, as God is not enslaved by the fact that $\mathrm{He}$ cannot sin. They rather make him free by bringing him back to his allegiance to the law (11. 671-700). The only idea different from this which is suggested as justification for the barons is that as it is the duty of the barons to defend the kingdom from the results of invasion by foreign enemies, so it must be to defend it from internal enemies and dangers (1l. $539 \mathrm{ff}$ ). If this argument were developed it would be a justification of the barons drawn from the feudal idea of their function in the state, but it is not developed and the discussion drifts immediately into the theological argument. The author of the poem seems to be most troubled by the difficulty of showing the right of the barons, not to remove evil councillors, but to impose others on the king, and this is of course the weak point of their case considered as a matter of legal right. We may regret greatly that we have no copy of the Abbreviatio de principatu regni et tyrannidis which Bishop Grosseteste wrote, and which Simon de Montfort apparently had in his possession (Monumenia Franciscana, p. 110; Stevenson, Grosseteste, p. 270), but if we had, it is not likely that we should then have any more full information than now of the grounds of right on which the barons supposed themselves acting. The word abbreviatio in the title may indicate that the 


\section{ORIGIN OF THE ENGLISH CONSTITUTION}

work was not original with Grosseteste, that he had merely summarized for practical use some older treatise. In any case it is very improbable that he stepped outside the circle of ideas on the subject which were familiar to the educated clergy of his time. The incident is of greatest value to us as revealing one line of connexion by which these philosophical and theological ideas were brought to bear directly upon the chief actors in the revolution. But their influence should not be orerrated. They no doubt encouraged the barons and made them believe that their cause was just and had the sanction of heaven, but they could not originate action. If the barons had known nothing of these ideas, they would have been led by the practical situation and the historical precedents to do exactly what they did, and without these they would not have acted upon the philosophical notions. In saying, then, that in 1215 the community established a right to compel the king to regard the law, I do not mean such basis of right as the Song of Lewes sought to formulate. Such abstract forms of justification will necessarily vary from age to age under the influence of men's changing philosophical predispositions. What had been established was a practical right, the right of precedent; men felt themselves authorized by what had happened in the past to do something of the kind which the present seemed to require, though no doubt from time to time contemporary philosophical ideas strengthened men's opinions and gave them confidence. Nor do I mean that the specific legal principle on which the barons acted in 1215, the diffidatio, was more permanent. Like many of the feudal rights which they sought to protect in the Charter, and which form the first content of the law which the king was bound to observe, it disappeared in time. It left behind, however, the precedent and the practical right of calling the king to account.

In regarding these cases as precedents for later action, they are to be considered in two respects in which they differ from one another quite distinctly, in respect to their value as precedents in law, and as precedents in time of revolution. Blackstone with judicial caution lays down the principle which should 


\section{IMMEDIATE RESULTS OF MAGNA CARTA}

rule in deciding how far they should be thought to. determine law, strictly speaking, and in this particular we should not go beyond him. In speaking of the case of James II. he says: "So far as this precedent leads, and no further, we may now be allowed to lay down the law of redress against public oppression. If, therefore, any future prince should endeavour to subvert the constitution by breaking the original contract between king and people, should violate the fundamental laws, and should withdraw himself out of the kingdom; we are now authorized to declare that this conjunction of circumstances would amount to an abdication, and the throne would be thereby vacant. But it is not for us to say that any one, or two, of these ingredients would amount to such a situation; for there our precedent would fail us." Commentaries, I. 245. It must be noticed, however, that Blackstone is speaking of strict law, and that in actual crises, like that of 1688, precedents like these strengthen the belief of the nation that it has the right to protect itself and its future by action which it may nevertheless recognize as revolutionary. 


\section{CHAPTER VII}

\section{The End of the Period of Origin}

In the baronial movement against the king in $\mathbf{1 2 5 8}$ the fundamental principle of Magna Carta, that the king is subject to law, was reaffirmed in more definite and more advanced form because in more definite and more advanced institutional expression. Later in the same movement the complementary principle, the right to appeal to arms to enforce upon the king conformity to the law, was also reaffirmed in the Barons' War and in the Confirmation of the Charters. Contemporary with this movement, and in part coming out of it, appeared the beginnings of another institutional growth of the greatest importance in English history. So great is the part which Parliament came to play in the actual making of the constitution, as the guardian of its formative principles during early stages of their development, and agent and actor in their final expression, and so closely connected were the origins of Parliament with the opposition to Henry III. in its later phases, that it seems necessary to notice to some extent the early history of Parliament. It is not proposed to trace in full detail the process of origin. That is unnecessary from any point of view, and especially so here, because my own 
opinion is very clear, as already expressed, that the active assistance of Parliament in the formation of the limited monarchy and its function as the guardian of the constitution, belong to a later and not to the earliest stage in the history of the constitution. It is desirable, however, to call attention here to certain of the facts relating to the origin of Parliament and to certain important relationships.

Institutionally considered, the origin of Parliament consists in bringing into the feudal curia regis, the great council of the first half of the thirteenth century, down to that time unchanged, certain persons who had no standing in it according to the strict feudal ideas of an earlier time, except as they might be given it in special cases by a direct exercise of the king's prerogative. ${ }^{1}$ The question of origin is a twofold one:

1 It is an interesting fact in the institutional history of England that, after the permanent division into two houses in the next century, the upper house was consciously regarded as continuing the curia regis and the lower house as something foreign to it. This is to be seen in such facts as the freedom of the members of the upper house, but not of the lower, from trial by jury; in some of the features of the struggle between statutes and ordinances; in the continued judicial power of the upper house in which the lower had no share; and in the form of the impeachment trial, so extraordinary that it is impossible to suppose that it could ever have been invented de novo, but easily seen to be a most simple and natural process when we carry it back to the old curia regis and consider the relation to that of the new elements which formed the House of Commons. As having no part in the judgment making function of the upper house, the lower easily assumed that of the prosecutor. It may be added to what is said above of statutes and ordinances that the history of the struggle in the fourteenth century to secure the right of the new elements' which had been added to the old curia regis to participate in all legislation, together with the fact that legislation of this 


\section{ORIGIN OF THE ENGLISH CONSTITUTION}

first, by what actual steps were these persons brought into the curia regis, and second, under the influence of what ideas, what led to their introduction and what was supposed to be accomplished by it. There should be added, for a complete account of the period of origins, the further question, what effect did their introduction have upon the curia itself?

It is impossible to examine even superficially the question of the origin of Parliament without being struck at once with a fact of considerable significance: no one at the time perceived that any change of importance was taking place. It attracted no special attention to itself. Neither in the records, nor in the chroniclers, is there any evidence that anything thought to be unusual, or to make a sharp break with customary ways of doing things, was seen to be going on. ${ }^{2}$ Whatever explanation is offered of the origin of Parliament it must be one which shows the first steps to have been taken in line with things already going on, with no wide divergence at any rate from processes in common use, or from current ideas. We

new type took the form of petitions, seems to imply that the House of Commons regarded itself at the beginning of its career as having a doubtful right to share in legislation, and an unqualified right in the matter of taxation only. This would be probable on other grounds also. Taxation as requiring originally in theory at least individual consent would stand in different relation to the House of Commons from legislation, for this had been the exclusive right of the curia regis.

2 See the note in Stubbs, II., Sec. 214. The word "Parliament" was not associated in any sense in the minds of contemporaries with the rise of a new institution. It had been in occasional use for at least ten years before 1254 for the old unchanged curia regis. 


\section{THE END OF THE PERIOD OF ORIGIN}

are led to suppose, for instance, by what occurs that by the middle of the thirteenth century a considerable decline of older feudal ideas must have taken place. While there is no doubt but that it would have been thought to be quite within the king's right a hundred years earlier, to invite a member of the county court, and possibly even a burgess, to attend a session of the curia regis, on occasion, if the king had undertaken to act upon this right in any wholesale way, to add a large body to the curia by summoning men from the county courts or boroughs all over England, it is altogether probable that the attempt would have found a much larger place in the chroniclers than is given to it when it was actually done in the last half of the thirteenth century. The function of these new elements in the curia regis during the first half century or more after their introduction must have seemed so nearly identical with some similar function already performed by members of the same class, in circumstances of the same kind, as not to appear to contemporaries a marked departure from things familiar.

It is generally considered that the first step in the continuous evolution of Parliament was taken in 1254. ${ }^{3}$ Early in that year the king in Gascony, finding an extraordinary need of money for his expenses, actual and contemplated, determined to attempt the raising of an aid in England from those who were 3 See note $A$ at the end of the chapter (p. 339). 
not coming to his assistance in person. His experiences in such attempts in recent years had not been happy. He had indeed quite as much reason to expect refusal as consent. By some one in the king's counsels the suggestion seems to have been made that if the consent of the counties could be obtained in advance, and that consent made known authoritatively to the council the chance of success would be greatly increased. It was probably also thought that if the king's necessities were fully explained and put in the right light, by the sheriffs to the county courts, they would readily agree to such a tax. This was the plan at any rate which was adopted. On the eleventh of February, a writ was issued from Windsor by the queen and the earl of Cornwall, who were conducting the government in the absence of the king, directing the sheriffs to act upon such a plan. ${ }^{4}$

The writ is an interesting one in more ways than one, but it cannot be here considered in detail. It first informs the sheriff that the major barons have promised their military service to the king in Gascony, and directs him to summon the minor barons in his county, those holding twenty librates of land in capite, to the same service. These all were to meet in London, on the third of May. Besides these, prceter omnes prcedictos, the sheriff is directed to send before the council at Westminster on April 26, two legal and discreet knights whom the county shall 4 Stubbs, S. C., pp. 375-377. 


\section{THE END OF THE PERIOD OF ORIGIN}

choose for this purpose, ad hoc, instead of the whole county, vice omnium et singulorum, to provide, ad providendum, with knights from the other counties what aid they were willing to give the king. If the writ stopped at this point, I think we should have little doubt that the knights were chosen to act in a representative capacity and that they were to consult together and decide about the aid after they had met at Westminster. But the writ does not stop here. It goes on to direct the sheriff to explain fully to the county court what the king's necessities were and to induce the county to agree to a sufficient aid, so that the delegated knights may be able to make an exact answer to the council for the county. The decision is clearly to be made in the county court and the function of the knights is to carry it to the council and to certify it officially. That this interpretation is correct is made more evident by the language of the writ issued upon the same day to the archbishop of Canterbury directing him to convoke the inferior clergy subject to him, to induce them in the same way to grant a liberal aid, and to see that they certify the council at the same date by discreet men the amount and manner of aid quod certificent consilium nostrum .... per viros discretos .... de modo et quantitate prædicti subsidii. ${ }^{5}$ Clearly the function of the delegates was to report a decision already

5 Printed in Prynne, Brief Register of Parliamentary Writs, I. 3-4, from Rot. Claus., 38, Henry III. $\tau$, d. 
reached by the local body. The modern idea of representation is not to be found here in spite of the language in the writs to the sheriffs, except so far as it may be involved in mere delegation, the knights speaking for the county in making known officially its decision. ${ }^{6}$

There can be no doubt, I think, but that the practice in use at the time which seems to have been most closely followed in summoning the knights from the

6 It seems to me also that there are grounds at least for raising the question whether the meeting of April 26, to which the knights were to report, was a great council. The first impression given by the writ of February 11, is that it was not so intended. The knights were directed to report on that day while the tenants-in-chief were summoned to be in London with their military forces on the third of May and presumably would not be expected to have their preparations completed and to be there a week earlier. A considerable portion of the tenantsin-chief were also already with the king in Gascony. 'The rccord dated May 17, Cal. Pat. Rolls, p. 370, shows that a "parliament" was held at the later date, but indicates nothing as to its character. The words of the writ of February 11, coram consilio nostro, while they could unquestionably be used at that date of the great council, are to be naturally interpreted of the small curia regis, and $I$ think would be more naturally so understood in 1254. The chroniclers (M. Par., Y. 440; Ann. Dunst., p. $190 ; J$. Oxenedes, p. 179), certainly describe the meeting of April 26 in the same terms that they would use of a meeting of the great council, but the accuracy of the chroniclers in regard to finer institutional distinctions is not sufficient to overcome any weight of documentary evidence. The exactness of Paris's account is doubtful also because his three weeks' delay would carry the date of meeting on to May 17, which does not agree with the entry on the Patent Rolls cited above, nor his statement that they had waited that length of time for Earl Richard with the entry on p. 368 of the calendar which shows Richard in Windsor on April 24, though following entries are attested by the queen alone which may mean Richard's absence. There is nothing to indicate where he could have been. It should be notieed also that the question of the aid did not concern the baronage as a whole but only those who had not been summoned to personal service. See the letter of 


\section{THE END OF THE PERIOD OF ORIGIN}

counties in 1254, and in what they were asked to do, was that employed in sending the record of a case tried in the county court to the central king's court. The practice was not an uncommon one and a number of instances of it, transcribed from the rolls, occur in Bracton's Note Book and present many points of similarity with the writ of February 11. They are discreet and legal knights, pl. 1730; they are sent per comitatum, 40; they come pro comitatu, 212; they act and speak pro comitatu, 40, 1436; pro toto comitatu, 445; their action is the action of the county, 1019, 1672. Their number is almost always four, but we have six, pl. 212, and two, pl. 1077, and Maitland, Pleas of the Crown, pl. 115. Here was certainly a direct line of connection between the county

February 14 in Shirley, II. 102. The "great council" of the editor's marginal note has no warrant in the text. The evidence is inconclusive either way, but I am inclined to believe that no meeting of the great council was called for April, and that what met was the ordinary council, reinforced very possibly by a few other magnates, a reinforcement which would require no special summons and would, at that date, still seem an entirely natural expansion. Whether it became in this way large enough to be actually a great council must be left undecided and is not a matter of importance. The council, whatever it was, apparently received the report of the chosen delegates and listened to an account of the king's insincerity from the earl of Leicester. M. Par., V. 440. It may possibly have sanctioned a proposition of the clergy to transfer to the king's use in Gascony the first year's returns from the tithe for the crusade on the conditions stated in Earl Richard's letter, Shirley, II. 102, Ann. Dunst., 189, but it refused the king any further aid.

7 The pro comitatu, pro toto comitatu, of these writs is every indication that we get in the political documents of this time of any consciousness of the representative idea. It seems to me impossible to assert that this is anything more than the merest nascent germ of the idea as we hold it. 


\section{ORIGIN OF THE ENGLISH CONSTITUTION}

court and the king's council (pl. 67, 1189), already established and in frequent use. The function of the two knights in 1254 seems to be the same. They brought to the king's council, in order officially to attest it, a record which had been made in the county, in this case a decision of the local body, the county court, for or against the granting of an aid to the king.

That the function which they performed had indirectly much in common with that of the jury is also evident: they made known to the council the local opinion and feeling on the question proposed. The practical result is not different. But if the two processes are compared step by step, it will be clear beyond question, I think, that the action of the two knights in 1254 corresponds far more closely with that of the knights carrying a record than with the jury.

8 The fact must also not be overlooked that the jury was primarily an institution of the itinerant justice court and of the corresponding permanent central court at Westminster. Cases where a jury appears clearly before the council are very few. See Staff. Hist. Coll., IV. 96. I know of no certain case in Bracton's Note Book. Cf. pl. 1209. A recognition reported to the council is another matter. See pl. 1249 for the process. Nor is the fact that a recognition appears on a coram rege roll evidence. The point is not of great importance because the failure of the first part of the thirteenth century to make any sharp distinction between the three courts, Couneil, King's Bench, and Common Pleas, which afterwards beeame distinct, is so apparent that in the first place an occasional case of the appearing of a jury before the council proper would not be strange, and in the second place a borrowing of the jury function from the central court and applying it in a case like that of 1254 to a question before the council would not seem to contem- 


\section{THE END OF THE PERIOD OF ORIGIN}

If this explanation of the model followed is accepted, it is evident also that no question could arise of the standing in the council, under the feudal law, of such a body of men from the county courts who were apparently not tenants-in-chief, 9 since they were present in no sense as members of the council, but merely as attesting officially a record which they were commissioned to carry.

No more than this can be said of the four knights who in 1258 were to report to the council on local abuses in the counties and complaints against the sheriffs, hardly so much indeed. The representative idea does not appear in any form in connection with their action. It is clear that they were appointed by the central government, not chosen in the counties, and the character of their office is indicated clearly by the direction given them to bring personally the

poraries to be an extraordinary departure from common practice. It is far more likely, however, that the practice which served as a model was the more frequent and familiar one in constant use in the business of the council, of sending knights from the county court with a record of its action.

${ }^{9}$ It is possible of course that tenants-in-chief holding less than twenty librates of land might have been included among the knights delegated, or in some counties perhaps formed the whole delegation, but the ehances as indicated by the language of the writ are rather against such a supposition. The number of tenants-in-chief holding less than twenty librates in any county who would be called knights in 1254 and who were not either major barons in some other county, or due to serve in the field as rear vassals for some other holding, was very small. The servitium debitum, however, does not seem to have been called ont for personal service in this campaign. It usually was not for service in France in the thirteenth century. On the position of these knights, see the note in Stubbs, II., See. 214 . 
results of their inquests, sealed with their own seals, and those of the others through whom they have made the inquisition, to Westminster consilio nostro ibidem. This is merely the case of an attested presentation to the council of a recognition made locally, a frequent practice. Very possibly the knights who brought it might be questioned by the council, but they certainly were not chosen for any deliberative purpose. ${ }^{10}$

It is in 1261 that we get the first indication of knights summoned from the counties who are to take part in the discussion of general interests with the body which they are called to meet. On September 11 of that year, Henry III. issued writs to the sheriffs in which he states first that the earls of Leicester and Gloucester and other magnates have called three knights from each of the counties quod sint coram ipsis at St. Albans on September 21 secum tractaturi super communibus negotiis regni nostri; and second, that on the same day, September 21, he and the said magnates are going to meet at Windsor ad tractandum de pace inter nos et ipsos. He therefore directs

10 For the writ commissioning the four knights see $M$. Par., VI. 396, and Ann. Burton, p. 456. Matthew Paris's own account, V. 714, is in strict agreement with the writ. His substitution of barnagio for consilio, as the body to whom the recognition is to be brought, is interesting. He says the writ was sent to the four knights, while Burton says it was sent to the sheriffs, which it clearly was not. Cal. Pat. Rolls, 1258, pp. 645-649, shows plainly that the knights were appointed, as also do the words of the apology for delay issued by the government on October 20, in the direction that wrongs committed be shown as quatre chevalers ke nus avum a coe aturne. Stubbs, S. C., p. 398. 


\section{THE END OF THE PERIOD OF ORIGIN}

the sheriffs to cause these knights to come to Windsor on that day, nobiscum super præmissis colloquium habituros. What the king says of the writ issued by the barons is all that we know of it, and from this it does not appear whether the three knights are to be elected or were named by the barons, though the implication of the king's writ is rather that the latter was the case. It is also not clear what body they were summoned originally to meet. The king says the barons had summoned them coram ipsis, but he might have said that of the council provided for by the Provisions of Oxford. Or the words may mean no more than that the magnates wished to get together representatives of the minor barons who were supporting them to talk over the situation-to hold a council of war of their party, rather than what would be technically, or would be assumed by them to be technically, a great council of the kingdom. The idea, however, that the knights called for were to take part in a consultation to be held after they met with the magnates must have been clear in the original writ. Again the king's writ gives us no more definite information about his purpose in the summons than about the barons'. He says they are to hold a colloquy with him super præmissis, but whether the premises are the super negotiis of the barons' writ or the de pace of his is not evident. It any case it would seem that their share in the proposed business was not to be a very active one, for it is implied that the chief object 


\section{ORIGIN OF THE ENGLISH CONSTITUTION}

of their attendance is that they may see and understand that the king proposes nothing against the honor and common utility of the kingdom. Nor does the king's writ give us any evidence that the meeting at Windsor was to be that of a great council, though it most likely was intended to be, in fact if not in form.

Confining ourselves to a strict interpretation of the one piece of evidence which we have, we must say of the incident of 1261 then that there is in it no indication of any choice of delegates by the counties, nor of a representative capacity in anything like the modern sense, nor of any connection with the great council, but that we do get here for the first time evidence of an intention, on the part of the barons at least, to have selected knights, we know not how, take part in a discussion to be held in some central body. Even if we reduce the case to these lowest dimensions, we may still fairly count it a step towards the future Parliament. ${ }^{11}$

The advance which we may at least say was foreshadowed in the writs of 1261 , was made beyond any question and with every appearance of a clear intention in June, 1264. The writ, which bears the date of June 4, served, like many writs of about this time,

11 The king's writ of September 11 is in Stubbs, S. C., p. 405. There is no evidence that the meeting which he said was to be held at Windsor took place, but the Annals of Wykes say that the barons refused to hold a conference (parliamentare) with the king in September. There is nothing in the king's character which makes it impossible to suppose that when he said in the writ that such a meeting would be held, he did so without warrant from the barons. 


\section{THE END OF THE PERIOD OF ORIGIN}

a double purpose. ${ }^{12}$ In the first place, it appointed Adam of Newmarket custodian of the peace in the county of Lincoln, and gave him instructions as to his duties. Second, it directed him to send to the Parliament about to be held in London pro toto commitatu four of the more legal and discreet knights per assensum ejusdem commitatus ad hoc electos . . . . nobiscum tractaturi de negotiis prædictis, that is, nostris et regni nostri. There would seem to be no ambiguity here either as to what was to be done or as to the purpose for which it was done. The delegates called for are to be elected by the county, they are to act for the county, not in the mere reporting of some action taken locally, but in discussing and determining national action not yet decided upon, and the body with which they are called to meet and act is the great council. It is possible that if we had the barons' writ of 1261 we should find the same things as clearly expressed in it, but we cannot conclude this from the king's writ, and with our present evidence we are shut up to saying that the Parliament which was meeting in London about June 24 was the first in which we can see unmistakably the beginning of the new institution. This is not saying that the earlier incidents we have noticed were not preparatory to this step, ${ }^{13}$ but it is saying that in no one of them can 12 Stubbs, S. C., p. 411.

13 Only, however, in the sense of making familiar the appearance of a large body of knights from the counties before the council. The essential departure from the past, without which we do not yet have the new 


\section{ORIGIN OF THE ENGLISH CONSTITUTION}

we prove the occurrence of anything which is essential to the new. We must not forget, however, that the writ of June 4, though in form a king's writ, was really issued by the insurgent barons lately victorious at Lewes. An innovation of this kind made by a revolutionary party, in the full tide of revolutionary influences, and needing to maintain its internal union as closely as possible, is not the same thing as if made by the historical and established government. The final adoption of the change might even be delayed by such a fact.

The writs issued in December, 1264, calling together the famous Parliament of Simon de Montfort of January, 1265, add nothing to the writ of the preceding June except the summons to citizens and burgesses. ${ }^{14}$ As the evidence has come down to us, we are obliged to judge the form of summons to these new elements, added to the old curia regis, by the form in the summons to the bishop of Durham. If we do so, we must say that the summons of December is less clear and explicit than that of June. It is highly probable, however, either that in the actual writs to the sheriffs and towns the form was as full as in June, or that it would be understood to mean as much and be acted upon in the same way. If we make this assumption, we may suppose at this time institution-the actual taking part with others in the central body in the discussion of an undecided question, and presumably having a voice in its decision-is lacking to our present knowledge in every earlier casc. 14 Stubbs, S. C., p. 415. 


\section{THE END OF THE PERIOD OF ORIGIN}

also election, representation, and participation in the business to be done. It is, I think, fair to say that the writs of June were as much Simon de Montfort's as those of December, to consider the two practically one case, and therefore to attribute to him, or to some one in his party at least, the entire innovation, of which in complete form we have here the first evidence. This includes, if the present discussion of the earlier cases has led to correct conclusions, not merely the admittance of burgesses, but also of knights of the shire to full standing in the great council, to full standing so far as the form of words used in the summons is concerned, whatever position they may have occupied in actual discussions. Undoubtedly, as Bishop Stubbs says, this meeting "was not primarily and essentially a constitutional assembly." It was a revolutionary assembly of the party of the barons. But in the forms observed it was constitutional, evident pains were taken with that side of things, and it was beyond question the theory of Simon de Montfort and his supporters that it was legally a great council.

Though this Parliament of Simon de Montfort contains all the constituent elements of the historical English Parliament, lords, county members, and borough members, it is easily possible to estimate too highly its influence upon the future. It falls still within the age of preparation. It is the beginning of an epoch of change, not its full fruition. To call it the origin of the House of Commons in any except 


\section{ORIGIN OF THE ENGLISH CONSTITUTION}

the narrowest sense, the sense of the occurrence together for the first time of these new elements, would be a serious error. The act was not creative. It determined nothing, rendered nothing necessary. It merely foreshadowed what was to be, and thirty years passed before exactly the same thing in all particulars occurred again. The greatest importance to us of the Parliament of January, 1265, is as a sign that the vast economic and social changes, which in the end determine the legal and the constitutional, and which we can trace at work in England from the dawn of the century if not before, were beginning to affect the forms of government. These ultimate forces were certain to accomplish this result before very long. It was inevitable at a time when stricter feudal ideas were rapidly disappearing and in a régime which was one of classes only, that a class so distinct as the burgesses, having so many interests peculiar to themselves in the conduct of government, and having also such rapidly increasing power and such means of making their power promptly felt, should be drawn into the central assembly, not perhaps because of any desire or demand of their own but because their support and concurrence had become important. The same changes with the same constitutional effects were taking place in many European states, and in the history of the movement as a whole the place of England is late rather than early. ${ }^{15}$ 15 Peculiarities in the history of the English Parliament as compared 


\section{THE END OF THE PERIOD OF ORIGIN}

Representatives of the third estate would beyond any reasonable doubt have been summoned to the great council by the close of the century if Simon de Montfort's writs had never been issued and for reasons different from those which influenced his action, the necessity of sustaining by every means a dangerous position. When the age of preparation, of feeling after the final form, was at last over, and the new institution, the Parliament of the future, opened its continuous history, received into itself the elements which were henceforth to constitute it, in the model Parliament of 1295, there is no evidence that any one recalled the experiment of Simon de Montfort as a precedent or that it had any influence upon what was then done. In the interval of thirty years between 1265 and 1295 almost every conceivable experiment in the form and character of a deliberative assembly for the nation had been tried.

It is of course true that if the burgesses were certain to be admitted into the older institution there was nothing in that fact or in any other circumstance of the time that determined the form and character which the new institution was to assume, and this was a question of vital importance for the future. Upon

with other countries make their appearance only when its organization begins to take shape and the minor barons unite with the burghers and the first estate withdraws, leaving a Parliament of two houses only. The peculiarities which affect English constitutional history in the development of liberty through Parliament are due to peculiarities of local government rather than of ideas relating to general government or to Parliament itself. 
it depended the existence of the constitution quite as much as upon the survival and the broadened significance of the ideas of the Great Charter, for in the course of a century Parliament was to assume the task of forming the limited monarchy in place of the inefficient baronial party. Before the middle of the fourteenth century indeed the barons had clearly shown themselves incapable of the constructive work demanded of them. 'The Provisions of Oxford stand as their high water mark above which they were never able to rise. The future of the constitution, the possibility of the limited monarchy, depended on the character of the new institution which was coming into existence during this formative age. In this sense we may say that the thirty years of Parliamentary experimenting form truly the critical period of English constitutional history.

More than one period in the constitutional history of England may rightly be called critical. The concluding years of the reign of Richard II., and the periods of the Yorkist, Tudor, and Stuart dynasties are all critical in one sense of the word. But in none of these was anything more than the form of the result really at stake. Its essential character was never involved. The attempt of Richard II. to reverse the course of things was very skilful and to a certain point successful, but it fell in a time of most rapid and vigorous constitutional growth, and if the accidental personal element in the case had not furnished 
a leader to the opposition one would have been found elsewhere. We have at least every reason to believe so from the consummate leadership that must in some form have directed the marvellous constitutional advance of the fourteenth century. The revolution of 1399 might have been postponed for a short time, but Richard could not have prevented it nor have defended himself against it.

The Tudors were the heirs of the Yorkist monarchy, and constitutionally, from the present point of view, the periods are to be considered one. While the will of the sovereign during this period was as supreme in the control of public affairs as under the early Angevin kings, and while a despotism was established theoretically full of the most insidious danger to the constitution, practically circumstances which were of the very nature of the situation compelled an amount of dependence upon Parliament or alliance with it which prevented any permanently disastrous result. Some years before the close of the period it became evident, not merely that the constitution had suffered no loss, but that the time was ripe for that new advance which would in all probability have occurred if the Tudor dynasty had remained in possession of the throne, but which was undoubtedly aided by the character of the first Stuart kings.

The whole Stuart period is usually considered one constitutionally, but from the present limited point of view it falls into two quite different divisions. The 
first age, to the accession of James II., not merely presents no danger to the constitution but is one of most decided constitutional development, not in the construction of machinery-except to a limited extent in the reign of Charles I.-but in the putting of machinery into operation, in the clarifying of ideas, and in a rapidly growing understanding of the true meaning of the principles already established. The peculiar character of the first Stuart period is given it less by an attempt of the kings to be rid of the constitution than by an attempt of Parliament to put the existing constitution into actual operation in spite of the preference and determination of the kings to continue the personal government which had up to that time been the rule. It is not a period of the slightest danger to the constitution. It is rather the age in which the constitution becomes conscious of itself, if we may say so, in which the attempt is made for the first time to operate the constitution in opposition to the sovereign, or, with regard to what resulted from it, to transfer the actual exercise of sovereignty from the king to Parliament. The reign of James II. presents a different case. His was an attempt to resist the progress of events, not by insisting upon doing what earlier kings had done-it was now too late to hope for success in that way-but rather by preparing to undo the work of the makers of the constitution and to repeat the attempt of Richard II. The revolution of 1688 and that of 1399 


\section{THE END OF THE PERIOD OF ORIGIN}

are as closely parallel as it is possible for two historical events to be, and the constitution was never in so great danger in the second as in the first period, and never in serious danger in either.

If by the critical period of English constitutional history is meant an age when the real character of the result as well as its form and details were at stakewhen the course of constitutional growth might have been turned in a different direction-we must find it, as we must in nearly every case of vigorous growth, near the beginning. In this sense the critical period of the English constitution, the decisive period which controlled the future, was the thirteenth century, and after the Great Charter had once been secured, and after the eventful and decisive reign of Henry III. had determined what its future was to be, the last sub-division of this general age of crisis was made by the years of Parliamentary experimenting, for in them the result was still at stake, the final set of the current was decided.

To understand how easily a different and far less efficient form might have been given during this period to the new institution, or indeed how little effort it would have required to have prevented altogether the formation of a really effective Parliament, it is only necessary to study the forms which the institution assumed during this transitional period. ${ }^{16}$

16 It may be said, I think, of the instances of the summoning of the new elements to Parliament between 1265 and 1295 that the idea of repre- 


\section{ORIGIN OF THE ENGLISH CONSTITUTION}

Especially instructive are the occasions when we find the two forms which were later most successfully employed by the French kings in weakening the Estates General and reducing them to the service of the crown-the division of the national Parliament into provincial assemblies and its division into distinct assemblies of the different estates. These forms occur without especial comment or protest. The danger which lay in them was not evident. Their competence within their separate fields was not less than that of a full Parliament of the next century, considering the difference of date. Nothing indicates that there would have been any difficulty in directing the future development of Parliament along the line of these precedents. Indeed the kings for some time continued to negotiate separately with some of the classes to avoid the difficulty of dealing with Parliament and were induced at last to give up the practice

sentation by delegates is becoming more common, perhaps habitual, and that the fact that these representatives are to take part in the decision of public questions along with the members of the old curia is getting clearer expression. See for instance the writs for the Parliament of January, 1285, Stublss, S. C., p. 465. In studying the development of the idea of representation no weight should be allowed, I think, to the quotation of the maxim quod omnes tangit ab omnibus approbetur in the writs of 1295, Stubbs, S. C., p. 485. Some one who was writing writs in the reign of Edward had a love for proverbial and banal phrases and a very good opinion of his own Latin style. See the quia prævisa jacula minus lædunt just below in the same writ and the writ to the burgesses of June 28, 1283, Stubbs, S. C., p. 467. The maxim quod omnes tangit is virtually quoted by Roger of Wendover under date of 1225, $M$. Par., III. 91, and by the bishops in their answer to the legate in 1240, M. Par., IV. 37 . 
only by the most skilful management of the House of Commons in the fourteenth century. It is not necessary to say, however, that if these had been the controlling precedents no Parliament would have been formed in the English sense and no constitution.

What saved Parliament and the constitution in this crisis was ignorance, was the lack of experience. Had it been as possible for Edward I. to foresee the future in this respect as it was for Charles V. and Charles VII. of France, and to understand the danger to the monarchy which lay in the growth of a strong Parliament, he could, so far as we can now see, and he probably would, have prevented it. It was hardly possible to do this after the close of his reign; it was entirely impossible after the deposition of Edward II.

With the formation of Parliament by the addition of the new elements to the curia regis, and with the virtual restoration to Magna Carta of the original clause 12 of Magna Carta, the period of the origin proper of the constitution comes to an end. It is the period of building upon the beginning which had been made that opens at once. From a time when no beginning of a constitution is apparent, when every circumstance promised the speedy formation of an absolute rather than a limited monarchy, and when the slight tendency earlier manifest in English feudalism to check a development of royal power had been so long without influence as to seem about to disappear, from such a time England had advanced 
through the three great crises which have been described to what is clearly a constitutional beginning, with a more or less organized opposition, acting upon clear and definite principles capable of wide application, and through a primitive but even then most efficient institution capable also of rapid and extensive growth. From this beginning Parliament made, as has been said, the enormous advance of the next century, until it became the guardian of the fundamental principles of the constitution. This it did by the attachment of conditions to grants of money; by cutting off all uncontrolled sources of revenue; by insisting upon the equal right of the House of Commons in all legislation; by extending parliamentary control from the income to the expenditure of the state; by declaring the king's ministers responsible to itself as well as to the king; by extending in the revolution of 1399 the right of deposition into a right of breaking the order of succession; and, as a result of that revolution, by denying the responsibility of members to the king for their action in Parliament. A bare enumeration of these achievements shows how very far the transformation went in that century of the old feudal absolutism into what may rightly be called a constitutional monarchy, and how very complete must have been the preparation afforded by the work of the thirteenth century. 


\section{THE END OF THE PERIOD OF ORIGIN}

Note A. The Writ of 1213

(Page 317.)

ThE supposed occurrences in August and November, 1213, which have been thought to foreshadow the introduction of a representative element into the curia regis, cannot, I think, be allowed to have had any effect on the final result. The writ preserred to us by Roger of Wendover, M. Par., II. 550 (Stubbs, S. C., p. 276), directing the presence of the reeve and four men from certain vills at Oxford, on August 4, to determine the damages sustained by the bishops, gives rise to difficulties which have occasioned much discussion. There is no reason, I think, for rejecting it out and out with Ramsay, Angevin Empire, p. 442, n. 7. The general form of such a writ is certainly followed, de damnis et ablatis is technical, and there is no reason why such an experiment should not have been tried. The only new thing about it would be the union of the juries of the vills in one place and this would not seem a serious innovation. The objection to such a united meeting is not institutional but practical-the difficulty of getting the men together from all England. The chronicler certainly transformed the writ (facerent) and in so doing very possibly made unconscious errors but an explanation which has been suggested by Professor A. B. White seems to dispose of the difficulties simply and completely. See A. H. R., XVII. 12-16, October, 1911. He brings into connection with the writ the passage in the Annals of Waverly under 1208, describing John's confiscation of the property of the church after the interdict, which reads: Qui [the royal commissioners] circueuntes regionem saisiaverunt bona clericorum mobilia et immobilia intra et extra, committentes curam rerum illarum in ' singulis villis vicinis hominibus, per quorum manus clerici perciperent de rebus suis necessaria. Ann. Wav., p. 260. The explanation then would be that the writ of 1213 calls upon those to whom the church lands had been committed, and who had had charge of them since 1208, to state the facts as to the bishops' 


\section{ORIGIN OF THE ENGLISH CONSTITUTION}

losses. The coincidence of the singulis villis, which would naturally be in 1208 as in 1213 royal vills, adds to the probability of this interpretation, for the reference to the royal domain vills in the writ of 1213 has been the most serious difficulty in our understanding of it. If there is an ojection to this interpretation, which I have not discovered, we must fall back, I think, upon the suggestion offered by Mr. G. J. Turner, E. H. R., XXI. 297-299, that the reference was really to the episcopal vills. This interpretation is strengthened by the form of the commission issued on October 19, 1234, to two clerks to inquire into the treatment of the lands of the abbot of Peterborough while in the king's hands. They are to go to Peterborough and "the sheriff of Northampton is commanded to bring before them four lawful men and the reeve of the several manors of the abbot in his county and such other persons as are necessary to make the said inquisition." Cal. Pat. Rolls, 1234, p. 78. Vill in the writ of 1213 should also be translated "manor." Perhaps with this should be combined the suggestion of Mr. H. W. C. Davis, E. H. R., XX. 289-290, making the action of the juries take place in the shire courts and the ministri report at St. Albans. The chronicler, having begun to change his writ, as noted abore, might easily have been misled by directions for the meeting of local juries at St. Albans. Whatever may be thought about this writ, we not only have no evidence that such juries actually came together at St. Albans, but we do know that the damages were determined later in another way. Rymer, I. 114;Ann. Dunst., p. 30. Whatever interpretation is adopted, the whole proceeding is different in form and purpose from anything connected with the later origin of Parliament.

The writ of Norember 7, 1213, Stubbs, S. C., p. 28\%, directing the sheriff to cause the knights of his county, summoned to Oxford for November 15, to come armed, and the general body (corpus) of the barons unarmed, and to cause four discreet men of his county to meet the king at the same time ad loquendum nobiscum de negotiis regni nostri, presents so many difficulties of interpretation that in the entire absence of other evidence

[340] 


\section{THE END OF THE PERIOD OF ORIGIN}

bearing upon the matter little that is definite can be said of it. It is plainly a writ supplementary to an earlier one and adds to it two things: first, that the knights are to come armed and the barons unarmed, and second, the direction as to the four men. Who the knights are it is impossible to say. Naturally we should suppose them the minor tenants-in-chief, here summoned in a body as no doubt often before. But the number of minor tenants-inchief is too small to justify us in supposing that the directions about arms imply, as would be the first inference, an idea on the king's part that he could find in them a force to be used in overawing the barons, who could not be expected to obey orders to come unarmed. If we suppose them to be the entire servitium debitum of the county, then it seems to me impossible to believe that any idea was entertained in 1213 of introducing this body en masse into a meeting of the great council. It would be a less severe stretch of possibilities to suppose a genuine representative idea behind the directions as to the four men, but that also seems to me impossible at that date. Quite possible would be a desire for discreet men from the counties to bring up evidence as to local facts of some kind, as in 1254, or even as may have been possible in the preceding August, but not more than this, I think. The ad loquendum phrase is all the evidence we have that the great council was to meet or did meet at that date, and all together the information given us is too slight to be of any value. All that can be said is that the idea occurred to somebody in 1213 that discreet men from the counties could be asked to be present at the same time and place as a meeting of the great council. If all that has ever been made of the case could be affirmed with confidence, we should still have to say that it remains an isolated and premature instance, without influence upon subsequent events. It would be most surprising if after forty years it should have been remembered by any one or have served as a precedent in any sense. Nor is there any similarity between the action it provided for and that called for by the writ of 1254 . 


\section{CHAPTER VIII}

\section{Magna Carta axd the Responsible Mivistry ${ }^{1}$}

As was naturally to be expected, the conclusion reached in the first edition of this book has not found universal acceptance. I have maintained that what is distinctive in the English Constitution, what has given it its unique place in the history of the world, that is, the principle and the constitutional machinery of a limited monarchy, was derived directly from the principles and practices introduced by Magna Carta, and that therefore the origin of the English Constitution is to be found in Magna Carta. In dissent it has been declared that the English Constitution contains far more than the machinery of a limited mon-

1 This chapter was first published as an article in the American Historical Review, July, 1915, vol. XX., 744-760, as a contribution of the seventh centennial of Magna Carta. It is republished by permission. In its preparation I made a special use of the following books and articles and would here acknowledge my indebtedness to them: Sir William R. Anson, The Law and Custom of the Constitution, I. 39-43 (1909), vol. II., chapter II. (1907); H. B. Learned, The President's Cabinet (1912), chapters I., II., III.; Sir William R. Anson, English Historical Review, XXIX. 56-78, 325-327; E. I. Carlyle, ibid., XXVII. 251-273; H. W. V. Temperley, ibid., XXVII. 682-699; XXVIII. 127-131; E. R. Turner, American Historical Review, XVIII. 751-768; XIX. 27-43, 772-794. The articles of Carlyle, Temperley, and Turner are concerned mainly with external forms. or the development of the cabinet. Sir William Anson considers more fully the idea of responsibility and Mr. Learned's book is valuable in the same direction. 


\section{MAGNA CARTA AND RESPONSIBLE MINISTRY}

archy. As I have anticipated this criticism in Chapter I., above, and explained with reference to it the sense in which I use the term constitution, I do not consider that the objection, put in this form, needs further discussion. It has been put in more specific form, however, by Dr. McKechnie in the second edition of his Magna Carta. He implies, justly I think, that I did not show the connection with the development begun by Magna Carta of one of the most important features of the present Constitution, the responsible ministry. Dr. McKechnie says:

The main line by which that monarchy has progressed from medieval to modern ideals has not been by the method, unsuccessfully attempted in 1215, 1244, 1258, 1265 and 1311 (to name only the best-known instances), of subjecting the King to the dictation of a Committee of his adversaries; but rather the method of using the counsellors of his own appointment to curb his own caprice, while making it progressively difficult for him to appoint any minister of whom the national council did not approve. ${ }^{2}$

The same point has been put in another way in a private letter which $I$ have received from a professor of history in one of our principal universities. $\mathrm{He}$ says:

The principle of Magna Carta that the King personally is subject to the law and can be coerced if he breaks it is not the principle of the constitution to-day. Just when and how was the modern principle that the King can do no wrong, coupled with the responsibility of his ministers to the law, substituted for it?

2 W. S. McKechnie, Magna Carta (1914), p. 127. 


\section{ORIGIN OF THE ENGLISH CONSTITUTION}

My critics plainly assume that the principle of ministerial responsibility originated outside the line of results derivable from Magna Carta, and one of them believes that it has taken the place in the present Constitution of the principle that the king is subject to the law. The question thus raised is a most important one. Ministerial responsibility has played so great a part in the practical operation of the English Constitution for more than a century; it seems to the student of the nineteenth century so clearly of the very nature of the Constitution and even appears to be its one essential feature; it has had so much to do with making possible the adoption of the Constitution more or less completely by all kinds of monarchies, from those that are virtually democratic republics to those that are scarcely modified absolutisms, that certainly no understanding of English constitutional history is complete until the source of that principle and the way in which it entered into the final result are clear.

There can be no doubt that an idea of ministerial responsibility is to be found in the Middle Ages and that it was to a considerable extent realized in fact. In the passage from which I have quoted, Dr. McKechnie enumerates by date the first clumsy experiments which were made in the effort to give institutional expression to the principle that the king may be compelled to keep the law. They were blind gropings after the idea of ministerial responsibility, so 


\section{MAGNA CARTA AND RESPONSIBLE MINISTRY}

vaguely conceived that no one saw a better way than to remove entirely the ministers of the king's appointment, or even to suspend the king's authority itself, and substitute for the time being ministers, or a kind of commission, directly responsible to the great council. Dr. McKechnie has seen clearly enough that modern ministerial responsibility did not grow out of these first instances, but they are by no means the only efforts during the Middle Ages to find some pacific, non-revolutionary method of enforcing royal respect for the law. The rapid growth of parliamentary power between 1310 and 1360, for only the faintest beginning had been made by 1310, introduced a new element into the situation. Not merely had Parliament in the interval greatly enlarged the body of law which the king was required to observe, ${ }^{3}$ but it had so perfected its own organization and won for itself so clearly a definite place in the Constitution, that it was prepared to take charge with great efficiency of the enforcement of the king's obligations, in place of the somewhat unorganized and inconsistent baronial opposition. ${ }^{4}$ To my mind it is indis-

3 The body of law to which the king was held subject had undoubtedly been much changed by the decline of feudalism and much enlarged by the development of national life, and especially by the principles referred to above, established in the growth of Parliament's power, but the continued influence of the fundamental principle of Magna Carta was assured by its simplicity and its adaptability to the changing conditions of social advance. See above, pp. 157, 169, note.

4 See above, pp. 157-167. With this compare Dr. Gaillard Lapsley in the Eng. Hist. Rev., XXVIII. 124 (1913), in a "note" on the "Commons 


\section{ORIGIN OF THE ENGLISH CONSTITUTION}

pensable to any understanding of the formation of the English Constitution to see that although the development of Parliament down to this point was independent of the line of development begun by Magna Carta, what took place shortly after the middle of the fourteenth century was the assumption by Parliament of the supervision of that line of development. ${ }^{5}$ What Parliament did in its first efforts to control the ministers of Edward III. was not something new in principle, nor a change of purpose, but it was to employ a new method of putting the old principle into operation. That a great advance was made at this point is beyond doubt, but the advance did not consist in the introduction of any new principle, nor indeed in any clearer perception or better formulation of the old, but in the better method which came into use through the higher organization of the

and the Statute of York." Dr. Lapsley, I think, dates the beginning of parliamentary supervision somewhat too early. It seems probable that the power of Parliament was too undeveloped before the last years of Edward III. to permit of any continuous guardianship of constitutional principles. The date is more clearly marked by the beginning of impeachment than by any other single fact.

5 Parliament laid the foundation for this assumption early in the fourteenth century in its efforts to obtain financial control, and it is surely not necessary to emphasize the important place given to this control, so far as recognized by the law of that day, in 1215 and in the actual practice of the thirteenth century. Nor is it necessary to point out that this control was definitely restored to the formal tradition of Magna Carta in 1297. It should, however, not be overlooked that upon this restoration was definitely based the first slight, step in parliamentary development in the grants upon conditions at the beginning of the reign of Edward II., and that upon this last was directly founded the whole construction of parliamentary power in the reign of Edward III. 


\section{MAGNA CARTA AND RESPONSIBLE MINISTRY}

body which assumed charge and the possibility of a more continuous and consistent growth.

The method employed from this time on in the coercion of the king was no longer to appoint over him a "committee of his adversaries," but to hold the ministers of the king's own appointment responsible to Parliament for what they did in carrying out his policy, or, if in some cases Parliament appointed, it was not with any special purpose of selecting the leaders of an active opposition. The new method is to be seen in the history of the treasurers during the last years of Edward III.'s reign, in the control of the councils of Richard II.'s minority and of the three Lancastrian reigns, and most perfectly of all in the process of impeachment. But however modern the description may sound which may be given of this new method, it is really distinguished from the modern and identified with the medieval by two most essential characteristics. In the first place it is the king who is coerced and not the ministers. The real executive is the king and the ministers are punished as a means of coercing him. Parliament has as yet no conception of itself as the final authority in determining the policy of the government, or of the ministers as carrying out its policy rather than the king's. In the second place, Parliament holds the ministers to a direct responsibility to itself. It compels them to report to itself, it brings criminal accusations against them, and punishes them with death. The modern

$$
\text { [34r] }
$$




\section{URIGIN OF THE ENGLISH CONSTITUTION}

indirect responsibility is not thought of. These two differences reveal an impassable gulf between the modern and the medieval forms of ministerial responsibility. The first indicates a vitally important difference of purpose and interpretation, and the second an institutional difference, in the mechanical operation of the principle, which alone would make its derivation from the earlier impossible. ${ }^{6}$ Modern ministerial responsibility has nothing in common with medieval beyond the name and the mere idea. Undoubtedly the abstract idea is the same, but constitutional history does not concern itself with abstract ideas, except to note them as sources of suggestion and impulse..$^{7}$ It deals with the institutional forms in

6 If, however, anyone is convinced that the modern is derived from the medieval form, it should not be difficult to see its direct connection with Magna Carta. As I have said above, the methods of coercion and control adopted in the last half of the fourteenth century and continued in the fifteenth, rest back for their foundation upon the principles brought into the Constitution in 1215. They are merely improved methods of doing the same thing that was attempted at that date and in 1258 and 1310 . This is true even of impeachment, the medieval expedient which passes on into modern times, for its object was not to transfer the initiative and control of government policy from the king to his ministers; that was an idea still in the far distant future and impossible to the fourteenth century. It was merely a new and improved method of coercing the king. If the modern were derived from the medieval, its origin would be far more conscious and deliberate than it was, and we should be able to discover the stages of change. It may be added that in the fourteenth century also the use of the counsellors of the king's own appointment to curb his caprice, and the making of it difficult for him to appoint any minister of whom the national council did not approve were still in the distant future.

7 The influence upon constitutional history of John Locke's attempt to 
which ideas are expressed and the way in which these institutions operate in the daily carrying on of government. In these particulars, in the matter of ministerial responsibility, a great change occurred somewhere between the fifteenth and the nineteenth centuries. ${ }^{8}$

Not merely in institutional form but in practical result, it is difficult to overstate the importance of this difference. Had the course of English history led to a constitution in which in form and law the ministry was directly responsible to Parliament instead of to the king, not merely would it have been immensely more difficult to reconcile the sovereign to a loss of the substance of power, but the adoption of the Constitution by other and reluctant monarchies would have been made a practical impossibility. The compromise feature of the present Constitution, by which in theory and in form the ministry, though supreme, seems to be the creature of the king and responsible to him, would have had no existence. The choice which

find a philosophical justification for the Revolution of 1688 in his second Treatise of Government was great in both France and America, but this fact does not make Locke's Treatise in itself considered a part of constitutional history.

8 What binds together in this respect the development of the English Constitution from its beginning in 1215 to the latest step which has been taken in it, is the effort to find some means of holding the king responsible without the danger of civil war and revolution. It is really this common characteristic, so far as we are not deceived by the mere name, which tempts us to identify medieval with modern ministerial responsibility, not the existence of a true institutional identity, for that is usually assumed without investigation. 


\section{ORIGIN OF THE ENGLISH CONSTITUTION}

without this compromise a successful revolution might offer to a sovereign between a formal direct responsibility of all the organs of actual government to the legislative assembly on one side, and an out-and-out republic on the other, would have been an even choice with no particular attractiveness or significance of one side above the other. The world influence of the English Constitution depended for its existence upon the fact that Parliament came to control the actual government indirectly, not directly; that an actual republic was concealed under all the ceremonial and theoretical forms of a continued monarchy. ${ }^{9}$

To show how the newer form of ministerial responsibility entered the Constitution, a brief outline of the middle period of its history is necessary, and this will also show, as I believe, that the modern principle is historically independent of the medieval experiments

9 I have said much on ministerial responsibility as aiding in the spread of the English Constitution throughout the world and accounting for its influence. I have no wish to modify these statements, but it must be noticed that they apply rather to the influence of the Constitution in the nineteenth century than earlier. The practical experience of the Continent, especially of France, with absolutism, and the effort which was made by the French philosophers to attack the theoretical foundation of an absolute monarchy, aided by the results reached in England, especially by Locke, in attempting to justify philosophically the revolution of the serenteenth century, gave to the English Constitution an influence in the eighteenth century which is derived from the general fact of limited monarchy, with comparatively little reference to the special institutional forms in which the fact was expressed. This is to be seen in the purely theoretical way in which, both in France and America, institutional details were discussed, and even experimented with, with no reference to the experience of England. 


\section{MAGNA CARTA AND RESPONSIBLE MINISTRY}

and what its organic relation with the fundamental principle of Magna Carta is.

If we go back to the close of the Middle Ages, or better to the beginning of the seventeenth century, for without the experience of the sixteenth century the accumulation of precedent essential in the final result was not complete, we shall find, as is well known, an impossible constitutional situation. At the accession of James I., there was upon one side a great body of history and precedent in support of the king's claim to govern by his own will. ${ }^{10}$ At the same date, there was upon the other side a great body of history and precedent in support of Parliament's claim that the king was bound to regard a certain body of law and custom in his action. This situation may be described in other terms which bring out more clearly its relation to our theme. England of the twelfth century

10 In addition there had appeared in the sixteenth century an important development of theory in support of such a claim in the idea of the divine right of the king. Theoretical support for Parliament's position was much less clearly developed at the beginning of the seventeenth century than for the king's, and a most interesting part of the history of that century is the gradual formation of this theory. This comes, I think, to its first full and clear expression in the resolutions of January 4,1649 , justifying the action of the House of Commons in proceeding single-handed with the trial of the king: "That the people are, under God, the original of all just power; that the Commons of England. in Parliament assembled, being chosen by and representing the people, have the supreme power in this nation; that whatsoever is enacted or declared for law by the Commons in Parliament assembled, hath the force of law, and all the people of this nation are concluded thereby, although the consent and concurrence of King or House of Peers be not had thereunto." Gardiner, Great Ciril War, IV. 290. 


\section{ORIGIN OF THE ENGLISH CONSTITUTION}

was an absolute monarchy with no constitutional limitation except that vaguely implied in the fundamental contract of feudalism, and no machinery for the expression of a will opposed to that of the king except the primitive and ineffective curia regis. The natural development of this absolute monarchy into a final Constitution was broken into by Magna Carta, which transformed the feudal interpretation of the contract relationship between the king and his barons into a general principle (the king may be compelled to keep the law) capable of far wider application and of expansion without change of substance to fit the needs of the expanding national life. From the date of Magna Carta on to the beginning of the seventeenth century, the two currents of constitutional development thus begun appear alternately upon the surface. The principles of a limited monarchy are enlarging and clarifying themselves until they are virtually complete in the fifteenth century, and the absolute monarchy is forced constantly into narrower channels by the concessions it must every now and then make to the increased weight of the opposing current. Down to the death of Elizabeth, however, much the larger portion of the past had been occupied by practical absolutism, while, except in the granting of taxes and in legislation, the limited monarchy existed rather in undeveloped principles. But these principles were so truly the result of experiment and experience that an imposing body of precedent could 
also be cited to justify their expansion in new applications."

These two contradictory interpretations of the Constitution stood over against one another in 1603. The issue between them had never been drawn. Since the working out of the limited monarchy and the establishment of its principles in $1399,{ }^{12}$ the two had never entered the field together. Each in turn had had possession for a long period, and government had been carried on according to it with no serious inter-

11 See an interesting instance of the citation of precedents on this side quoted by Taswell-I.angmead, English Constitutional History (seventh ed., 1911), p. 432, and there attributed to Sir Robert Cotton: "We do not desire, as 5 Henry IV., or 29 Henry VI., the removing from about the King any evil councillors. We do not request a choice by name, as 14 Edward II., 3, 5, 11 Richard II., 8 Henry IV., or 31 Henry VI.; nor to swear them in Parliament, as 35 Edward I., 9 Edward II., or 5 Richard II.; or to line them out their directions of rule, as 43 Henry III. and 8 Henry VI.; or desire that which Henry III. did promise in his 42nd year, se acta omnia per assensum magnatum de concilio suo electorum, et sine eorum assensu nihil." On the attribution of this speech and the question of its delivery see S. R. Gardiner, Debates in the House of Commons in 1625 (Camden Society, 1873), pp. xx.-xxiii., and History of England, V. 425, note (ten-vol. ed., 1883), and cf. Forster, Sir John Eliot (1872), pp. 243-250. If it be true that "this speech was not spoken but intended," the sentence is still a good example of the way in which precedents were used on the parliamentary side. 12 It is no exaggeration to say that after the Revolution of 1399 the English Constitution was in existence so far as all its fundamental principles are concerned. Much had still to be done in finding out all that those principles implied and this was the work of the seventeenth century; much had still to be done in applying them consistently to the details of government, especially in the control of finance, in the independence of the judiciary, and in the directing of foreign policy; and much had still to be done in devising machinery for their practical operation, and of this the chief instance is the cabinet with ministerial responsibility. 


\section{ORIGIN OF THE ENGLISH CONSTITUTION}

ruption from the other. The Lancastrian period, "startlingly and prematurely modern," is in fundamental principles, though these had not been worked out in all details, an age of constitutional monarchy. The Yorkist and Tudor periods form an age of practical absolutism, though an absolutism which for its own convenience made use of some of the machinery of a constitutional monarchy and in so doing strengthened and confirmed it.

With the accession of James I. we enter upon a period of constitutional growth new in character to all English history, if we except the brief struggle under Richard II. On his side the king was determined that the Constitution should be operated according to his interpretation of it and on its side Parliament was equally determined that its interpretation should prevail. From such an issue only two results were possible. It might be that one interpretation should prevail to the exclusion of the other, or it might be that a workable compromise should be found between them. It is not necessary for our purpose to follow the struggle between these conflicting ideals; it is necessary to see that the result was a workable compromise between them of which the essential feature was destined in the end to be the modern responsible ministry.

Let us state the result with reference to 1660 and following years, rather than with reference to the [ 354 ] 


\section{MAGNA CARTA AND RESPONSIBLE MINISTRY}

past. The struggle with Charles I. established finally and forever the principle that actual sovereignty, the right and power of ultimate decision, was vested in Parliament as representing the nation. How completely this fundamental question had been decided in Parliament's favor is revealed by the unanimity, almost without exception, with which the nation rallied to the support of that decision when the final test came in 1688. But although this was the result established in reality, it was not the result established in form. Parliament was not able, or did not wish, to render permanent all that the Puritan party had accomplished, or felt itself obliged to attempt, in the change of government forms. The last period of the Protectorate saw a strong reaction in favor of the monarchy as the historical and natural government of the state, and the result was the restoration of the Stuarts without constitutional guarantees. ${ }^{13}$ In form such a settlement left the issue between the two conflicting constitutional interpretations of 1603 undecided. In reality it had been decided in favor of the parliamentary interpretation, and Charles II. was

13 This is of course the great difference between the settlement of 1660 and that of 1668-1669. The experience of the intervening years convinced the nation that the king must be far more definitely and specifically bound than ever before to a faithful observance of the fundamental public law as it then stood. The guarantees of 1688 included, however, no pledge to any form of constitutional machinery by which the sovereignty of Parliament, its right of ultimate decision, was to be practically exercised. 


\section{ORIGIN OF THE ENGLISH CONSTITUTION}

perhaps even more conscious of this fact than was Parliament itself. ${ }^{14}$

That the settlement of 1660 was a compromise needs hardly to be proved. That it was unexpressed and unnoticed, made not by negotiation but by the force of events, does not make it less truly a compromise. On one side the form was surrendered but what proved in the end to be the reality retained; on the other the reality was given up but the surrender was disguised under the appearance of power and, more than that, for a long time under the actual exercise of very substantial powers and the permanent possession of important rights and influence. It was more than a hundred years before all that the compromise implied was clearly recognized and the balance established at its present level. But the compromise was really made at the Restoration, though it was afterwards so seriously attacked by James II. that it needed to be reaffirmed in more definite form in 1689 .

Constitutionally the result was something new to all the experience of history: in form sovereignty was vested in the king, in reality it was vested in Parlia-

14 The form in which the compromise is stated by the modern constitutional lawyer (sovereignty resides in the king in his Parliament) is exceedingly interesting. One is instantly reminded by it of the declaration of the Long Parliament that "the King's supreme and royal pleasure is exercised and declared in this High Court of law and council, after a more eminent and obligatory manner than it can be by personal act or resolution of his own" (Gardiner, Documents, p. 257). But as a formulation of the compromise of 1660 , the phrase is as correct as it is interesting. 
ment, and the problem of carrying out such a settlement in practical government, though no one was conscious of it at the time, was a most serious one. Naturally, as a new thing in the world, no machinery existed by which sovereignty could be exercised in practice by a representative body while in form it remained the prerogative of the individual monarch. ${ }^{15}$ By the mercy of Providence Charles II. possessed, probably by inheritance from his mother's house, a degree of tact and political insight which makes him an exceptional Stuart. As a consequence the fundamental contradiction was never drawn out into a square issue in his reign. When a Parliament,

15 The want of any machinery for carrying out in the practical working of government the compromise between king and Parliament and the difficulty of inventing satisfactory forms are clearly shown in the experimenting which went on in the reign of Charles II. as described in the books and articles referred to in note 1. Particularly interesting are some of the expedients adopted from their similarity to methods employed in Washington during the past thirty years in efforts to bring the influence of the executive to bear on legislation. See especially the passage quoted by Carlyle, Eng. Hist. Rev., XXVII. 260, from the Continuation of the Life of Clarendon, §395: "These ministers [Clarendon and Southampton] 'had every day conference with some select persons of the house of commons, who had always served the king, and upon that account had great interest in that assembly, and in regard of the experience they had and their good parts were hearkened to with reverence. And with those they consulted in what method to proceed in disposing the house, sometimes to propose, sometimes to consent to what should be most necessary to the public; and by them to assign parts to other men, whom they found disposed and willing to concur in what was to be desired: and all this without any noise, or bringing many together to design, which ever was and ever will be ingrateful to parliaments, and, however it may succeed for a little time, will in the end be attended with prejudice." 


\section{ORIGIN OF THE ENGLISH CONSTITUTION}

usually subservient, reached a point beyond which it would not go, as in the case of the Declaration of Indulgence, the king yielded, and in spite of all the practical control of government which he succeeded in gaining, the power of ultimate decision remained with Parliament. He was forced to the same conclusion to which his grandfather and father had been forced, that, if he wished to govern by his own will, he must govern without a Parliament. To the end of the reign of Charles II. there was no development of new machinery by which the compromise as to sovereignty could be carried into practical operation. As a matter of fact the compromise worked in practice imperfectly and rather because of the caution and restraint of the king than because it was clearly understood or institutionally expressed. The king chose his own ministers and controlled their policy and did not concern himself with Parliament's approval of them nor consistently with Parliament's approval of his policy, and he was still the real executive. On its side Parliament knew no way of exercising its power of final decision, except by making a square issue with the king, nor of holding the king's servant responsible except by asserting a direct responsibility enforced by the old practice of impeachment.

In the next reign the king proceeded so rapidly and with so little judgment to re-establish a personal government that the old issue was speedily drawn again and as sharply as in 1642. Only one result was 


\section{MAGNA CARTA AND RESPONSIBLE MINISTRY}

possible, for practically the whole nation was determined to maintain the settlement of 1660 so far as that was a settlement of the fundamental question of the supremacy of Parliament. Had constitutional machinery been devised during the reign of Charles II. for exercising that supremacy in practice, it would undoubtedly have been included in the settlement of 1689. But it had not been, and indeed in 1689 it was only the fundamental principle of parliamentary supremacy that was in any sense apprehended. Neither the range of its application to the operation of actual government, nor the method of its application, were yet understood, nor was the latter, which is the principle of ministerial responsibility applied to the cabinet, clearly understood for another century.

With the accession of William III. we enter again upon a new epoch of English constitutional history. The fundamental question at issue between Parliament and the Stuarts, where does sovereignty reside in the English state, had been settled never to be raised again. The most characteristic feature of the new age was not a question of fundamental principles or of general interpretation, but it was progress in devising machinery by means of which the decision of the fundamental question which had been already reached was to be put into practical operation in the details of government. No more than a beginning was made during the reign of William III. and, so far as any clear consciousness of what was really

[ 359 ] 


\section{ORIGIN OF THE ENGLISH CONSTITUTION}

going on is concerned, there was not even a beginning. In truth considerable progress was made during that reign and the next towards what was ultimately to be the result, the responsible ministry, but the progress of the period shows itself wholly upon the side of practical affairs, not at all in ideas or understanding. William III. still retained a very decided control over the conduct of government, particularly in foreign affairs, and over the choice of ministers. He never dreamed of allowing Parliament any voice direct or indirect in this latter matter. He made a beginning, however, through practical experience upon the lesson which was more fully learned in the next reign, that the easiest way to accomplish what he desired, the line of least resistance in carrying out his policy, was to choose his chief ministers from those political leaders who were best able to secure the support of Parliament. This was a most important discovery. I am not asserting that its bearings were as yet understood. It was not as yet a matter of principle but of mere momentary convenience, but it was in truth the germ from which grew the later doctrine of ministerial responsibility with all its applications in the present constitution. ${ }^{16}$

16 The cabinet and the responsible ministry are coming into existence at about the same time and by parallel lines of development. The origin of the cabinet need not be here discussed, but that it can be traced, as the beginning of a continuous growth, to any period before the reign of Charles II. seems to me exceedingly doubtful. It will be understood, I think, without special discussion that. the existence of a cabinet does 
This change may be described in other terms. In the reign of Charles II. impeachment, representing the old form of ministerial responsibility, was a survival, in the scientific sense of the word, destined speedily to disappear, and the new and modern form was foreshadowed on its institutional side in the experiments to find a mediating, harmonizing body between king and Parliament. Of these Sir William Temple's proposed reorganization of the Privy Council is the most famous, but it is not the one from which the modern form developed. That came more directly from the disliked and suspected ministerial clique which the king himself formed, but rather from that as it was re-established under William III. than from Charles II.'s. The birth of the idea of ministerial responsibility on the other hand can hardly be traced back so far and is to be found coming into existence very slowly after the beginning of the eighteenth century, though the idea was in a sense involved in such an experiment as Sir William Temple's.

How wholly unconscious was the real development

not carry with it the idea or practice of ministerial responsibility, as it does not in the United States, and that the two are independent in origin. I must emphasize here again, however, as $I$ have elsewhere in regard to the origin of the representative systern and of taxation, the necessity of distinguishing in constitutional history between ideas and the institutions in which they are embodied, or by means of which they are operated practically. The two are often in origin and early development quite independent of one another and the failure of the historian to notice the distinction often results in unnecessary confusion and difficulty. 


\section{ORIGIN OF THE ENGLISH CONSTITUTION}

which was going on at that time is strikingly recorded in the Act of Settlement of the last year of William's reign. In clauses IV. and VI. of that document, as is well known, Parliament attempted to destroy the beginnings of the cabinet system in order to protect what it believed to be its means of enforcing responsibility and, if those clauses had been put into force, would have succeeded. That is to say, Parliament had so little conception of how best to realize its own supremacy that it deliberately tried, in the interest of an obsolete method, to end the line of progress which was bringing in the most effective means ever devised, or apparently devisable, for operating a republic under the forms of a monarchy.

The continued ongoing of a development not understood by the statesmen of the time but showing itself more and more plainly in the facts is the most interesting feature of eighteenth-century constitutional history. The fortunate accident that foreigners came to the throne with the accession of the House of Hanover, who did not know the effect of what was occurring upon their position or, if they suspected it, did not know how to prevent it, combined with the fact that statesmen and observers were equally ignorant, secured half a century of growth prefectly natural, undisturbed either by opponents or theorists. How modern the result was becoming is shown by a series of facts occurring toward the middle and end of the period, and how unnoticed it was is

\section{[362 ]}


equally shown by the isolated character of these facts, that they were not even thought of by any one as common characteristics of a single constitutional result. ${ }^{17}$

The character of the result is also shown by another fact which the eighteenth century could not understand but the meaning of which is clear to us, the dropping of impeachment as a parliamentary weapon. $^{18}$ There is no case of impeachment in the old

17 The first two reigns of the House of Hanover form a period more important in the development of the cabinet than of the idea of ministerial responsibility; in fact the very smoothness of cabinet development to the fall of Sir Robert Walpole probably hindered to some extent any clear understanding of the relationship which should exist between the cabinet and the legislature, or of the way in which the legislature might control government policy and administration through its control of the cabinet. If, however, there was apparently little progress in the understanding of the facts, there was a steady drift in the facts themselves towards the principle that the cabinet must be in harmony with Parliament, or with the public opinion of the country. This is the meaning of the fall of Walpole in 1742, of the failure of Granville to form a ministry, and of the appointment of Pitt to the ministry in 1746, against the will of the king, as well as of the circumstances of his final accession to the cabinet about ten years later, to go no farther.

18 How puzzled contemporaries were by the changes which were going on is shown by the debates on responsibility which occurred in the generation following the Revolution. Parliament is vaguely conscious that its old weapons to enforce responsibility are out of date and useless, but is utterly at a loss to understand what to employ in their place. The reason why impeachment became obsolete is exactly the same as the reason why the royal veto did in the same period. In one case the reasons are regarded from the side of Parliament, in the other from the side of the king. Conflict of the old sort between executive and legislature, requiring the use of either weapon, was no longer possible. Conflicts of the new age were between phases of public opinion represented by parties in the legislature and both nominal and real executive were wholly dependent upon the legislative result. 


\section{ORIGIN OF THE ENGLISH CONSTITUTION}

sense after the close of the struggle with the Stuarts. Contemporaries believed that the impeachment of Somers and his fellows in $\mathbf{1 7 0 1}$ for their share in the Partition Treaty was an instance of its use for the old purpose, but plainly it was not, nor was any later impeachment or proposed impeachment. ${ }^{19}$ It is hardly necessary but it serves the purpose of this discussion to state the reason why. Impeachment had been devised in the struggle between king and Parliament over the old issue, the seat of sovereignty in the state. Its purpose was, exactly like that of clause 61 of Magna Carta and every other expedient of the old type, to hold the king to a real responsibility without the danger of civil war and revolution which would result in those centuries, and perhaps at any time, from holding him to a formal responsibility. For this purpose it was the most effective of all the older expedients, though all of them were in a way successful when the king did not obstinately insist upon his own responsibility. But that issue was now settled. It never reappeared after the Revolution of 1688. The real issues were no longer those of a fundamental interpretation of the Constitution between king and Parliament, but those of purpose and policy

${ }^{19}$ Hallam says that these impeachments "have generally been reckoned a disgraceful instance of party spirit." See Constitutional History (1854), III. 144-145, 230. It may be added that the practice of withholding supplies as a means of coercion has also been practically abandoned for the same reason. 


\section{MAGNA CARTA AND RESPONSIBLE MINISTRY}

in the daily operation of government between the leaders of groups of opinion in the nation whose equal loyalty to the Constitution was unconsciously accepted early in the period. In such a situation it was instinctively felt that it was an unworthy use of a party advantage to subject the leaders of the opposite side to a criminal prosecution and, though it was not yet seen what could be used in its place to enforce responsibility, impeachment was tacitly dropped. ${ }^{20}$

With the accession of George III. there came to the throne a king who, if he did not understand the cabinet system as we do, understood at least what its growth had cost the crown. It is significant of the great change which had come about in a century that George III.'s attempt to recover power was not an attack upon the settlement of 1660 , it was no attempt to raise again the issue of the fundamental interpretation of the Constitution, but it was an attack upon the

20 The only coercion of the executive which any one would now think possible is the coercion of a cabinet which refused to yield to any of the ordinary means of discipline. Until the day of revolution comes, this would surely be coercion in a party conflict, that is, upon a question of public policy, not upon a fundamental constitutional issue. Such constitutional questions as have seemed to arise in the last hundred years have not been questions of the fundamental nature of the Constitution as a whole but of the date, degree, and method of further advance in a development to which in general the Constitution was already committed. I believe this to be essentially true of the questions raised on the passage of the Parliament Act, though the changes which it has made are of far-reaching importance.

The outside observer is tempted to believe that the tendencies of British political life during the past twenty years, with the great majorities returned in parliamentary elections, the growing strictness 


\section{ORIGIN OF 'THE ENGLISH CONSTITUTION}

results achieved since the death of William III. Neither king nor cabinet understood, however, during the first period of the reign the full meaning of the new institution. Had it been understood, had ministerial responsibility of the modern type existed then, it is no exaggeration to say that the American Revolution would not have occurred. But the ministry of Lord North was the real accomplishment of the king's purpose, and a real return to the situation under William III., when the king determined the policy of the government and the business of the cabinet was to carry out his policy under a direct responsibility to him and only a secondary responsibility to Parliament. The failure of the attempt to bring the colonies back to their allegiance was also the failure of

of party bonds, and the probable effect of some of the legislation adopted, have been away from the supposition which lies at the basis of ministerial responsibility, the supposition that members of the House of Commons who have supported the cabinet on one measure will rote against it on another. It would seem hardly possible that this tendency should go much farther without destroying ministerial responsibility of the old type and making the cabinet the absolute master of Parliament. It may be added that the situation in this respect during the Great War, while doubtless abnormal and temporary, probably indicates a natural tendency. While undoubtedly ministerial responsibility, as it existed thirty years ago, secures a more democratic government than the American system, with its complete separation of executive and legislature, that is, a government which yields more quickly to changes of public opinion, if the result suggested above should occur it would then be open to question whether the American system, with its more frequent congressional elections, would not prove more democratic. It is interesting to note that during the same period, the past thirty years, the direct influence of the President upon congressional legislation has increased very greatly though by methods that are indirect. 
this last attempt of all to interfere with the natural development of the Constitution.

It is my belief that the event which had the greatest influence in bringing the public mind of Britain to an understanding of the cabinet system and the modern principle of ministerial responsibility was the struggle of the younger Pitt to maintain himself against a hostile House of Commons. He succeeded but his success rendered another like it impossible. But this was not even then an immediate understanding. Full understanding comes slowly and gradually, by an unconscious process of reflection, not by revelation, through the next twenty-five years. Two incidents between 1784 and the close of the century show how incomplete the understanding still was. Three years after Pitt's triumph the Constitution of the United States was framed by a large assembly of the most experienced public men and students of politics in America, who considered with care the problem of setting up a government to operate in the best way. One great problem before them, set by the situation of the time, was to secure a really effective executive while leaving ultimate authority in the legislature as representing the people, exactly the problem which ministerial responsibility solves. In their Constitution, however, not merely did they entirely separate the executive and legislative departments, ${ }^{21}$ but they

21 The practical result of the English cabinet system, though a result never theoretically desired or intended, is a union of the executive and 


\section{ORIGIN OF THE ENGLISH CONSTITUTION}

gave little attention to the cabinet, and they seem to have had no idea whatever of ministerial responsibility. It seems altogether probable that they thought that in this respect they were following the English model, as beyond question they did when they adopted impeachment, and certainly, had there existed in England any such definite idea of ministerial responsibility as fifty years later, there would have been some discussion of it in the Convention. The other incident is even more indicative of English understanding. In 1791 Parliament under the leadership of Pitt's ministry framed a new government for Canada. The debate on the bill shows conclusively that the desire was to give to Canada the same kind of government which England had, and I think there can be no question but that this was honestly intended. And yet no responsible ministry was granted, or even proposed, and the foundation was

the legislature. That this result was not foreseen when the first steps towards it were taken in the second half of the seventeenth century is evident from the ideas of Clarendon and Locke on the separation of the departments of government. On Clarendon see Carlyle, Eng. Hist. Rev., XXVII. 252-253, and on Locke the second Treatise, chapters XII. and XIII. Locke's ideas no doubt had a good deal of weight in America, but if the European cabinet system had been generally understood the advantages of that system as compared with Locke's ideas would, it is likely, have been carefully considered and the resulting decision in America would have been at least doubtful. See the thorough study of the Convention's attitude towards a cabinet in Learned, The President's Cabinet, chapter II, and cf. Farrand, Framing of the Constitution, pp. 166, 171. 
laid for the later Canadian rebellion which opened a new era in British colonial government. ${ }^{22}$

It is from the opening years of the nineteenth century that we must date a full understanding of the cabinet system and of the way in which ministerial responsibility is enforced through it, though even then the understanding was rather that of practical action than of theoretical description. ${ }^{23}$ It was not until about the middle of the century that descriptions of the system were written that seem satisfactory to us, and well past the middle before any treatise was published upon the new Constitution as a whole.

The conclusion from this outline sketch seems inevitable. The break between the medieval form of ministerial responsibility and the modern was complete. In the period from 1688 to 1714 the new was beginning to take shape, but the old had in every real sense already disappeared. Contemporaries were

22 See my paper, "The Influence of the American Rerolution on England's Government of her Colonies," Annual Report of the American Historical Association for 1896, I. 373-389; Lord Durham's Report (ed. Sir C. P. Lucas, 1912), vol. I., chapters III., IV., and V., vol. II., pp. 76-82, 277-285; F. Bradshaw, Self-Government in Canada (1903); A. B. Keith, Responsible Government in the Dominions (1912), pt. I., chapter I.

${ }^{23}$ See the account of the literature in Learned, pp. $37 \mathrm{ff}$. Even so acute a student of constitutional history as Hallam did not clearly understand the change which had been made by the cabinet system, and did not later modify the statements of his first edition of 1827. Const. Hist. (1854), III. 183-185; (first ed., London, 1827), II. 535-539. A considerable influence in the development of nineteenth-century opinion and understanding was the discussion in England between 1830 and 1840 of the Canadian demands and Lord Durham's Report of 1839.

[369 ] 


\section{ORIGIN OF THE ENGLISH CONSTITUTION}

wholly ignorant of what the new was to be, but they felt that the old was gone. They discussed the evil case in which they were left, they sought to find some way of holding ministers responsible, they even tried to revive the old method, but their discussions and attempts led to nothing. ${ }^{24}$ The new came into existence without regard to their efforts and by the force of events which they did not understand. But it grew neither out of the old issue between king and Parliament, nor out of the old forms of coercion. Its origin is to be found in the efforts to work in daily government the compromise made in 1660 . The English cabinet is a piece of machinery devised for operating a government in which sovereignty, and therefore the real executive, is actually vested in a legislative assembly, while in form it is vested in a personal monarch. Ministerial responsibility, operated by what we call party government, is the method of coercion applied in such a Constitution to the actual, not to the theoretical, executive. It has for its object not merely to compel the executive to regard the fundamental law of the state, which is a principle now so thoroughly established that it is nerer likely to be questioned, but also to carry out in the 24 See Anson, Eng. Hist. Rev., XXIX. 63. Direct coercion of the king was even thought of: "Harley after reminding his hearers that they had their negative voice as the King had his, and that, if His Majesty refused them redress, they could refuse him money, moved that they should go up to the Throne not, as usual, with a Humble Address, but with a Representation." Macaulay, chapter XX., vol. IV. (1858), pp. 483-484. 
details of government the policy which Parliament decides upon. In one sense, in the sense of everyday practical action, it may be said to have taken the place of the older principle of the right to coerce the king, but in truth it is that principle applied to the real executive and the older form still exists in the background of the Constitution, and conceivably might be called into action in some revolutionary age.

If it is true that the limited monarchy is derived from the principle introduced into English history by Magna Carta, that the king may be compelled to observe the fundamental law of the state, then both the medieval and the modern forms of coercion, though independent of one another, belong equally in that line of development. ${ }^{25}$ The struggle of the seventeenth century was the last struggle of the absolute monarchy to maintain itself against the limited monarchy. From the side of the limited monarchy it was a period when the foundation and final defense of that form of constitution, in the will of the people expressed through their representatives, came to be apprehended. But all alike, the triumph of limited

25 If any one will read the Bill of Rights with the thought consciously in mind that the fundamental principle introduced into the English constitution by Magna Carta was that the king must keep the law and that if he will not he may be forced to do so, I believe it will be at once clear that, in spite of all the changes of form and method in the interval, there had been no change in this fundamental principle. It is, in the simple form in which I have stated it, the obvious foundation on which the Bill of Rights rests, and which it almost states in so many words. 


\section{ORIGIN OF THE ENGLISH CONSTITUTION}

monarchy, the discovery of its scientific justification, and the machinery invented to carry it into practice, belong historically in the direct line of evolution begun by Magna Carta, are later stages of the development which first dates from it. 


\section{APPENDIX I}

\section{The Descendants of the Curia Regis}

THE publication by Mr. L. O. Pike in 1907 of a chart of the descent of English institutions, ${ }^{1}$ led me to print ${ }^{2}$ a somewhat similar chart which I had used for a number of years in my instruction in English constitutional history in Yale College. I judge from letters received that it may prove useful to reproduce it here.

It will be seen at once on comparison that Mr. Pike's chart is more complete than mine, that it contains more detail, and gives more attention to chronology. ${ }^{3}$ My own was kept intentionally free from detail, and made to include only the larger features of the constitution in order to bring out as clearly as possible, for class room purposes, the relation of the principal modern institutions back to the curia regis, and the generic position which the curia occupies in constitutional history. From its very simplicity, I venture to think that this chart brings out graphically these points and relationships, which it is of great importance

1 The Public Records and the Constitution. A Lecture (London, 1907), by Luke Owen Pike.

2 In the American Historical Review, XIII. 11-15 (1907). Repetitions in this appendix of points made in the text in other words are intentionally left standing as originally written. I have also allowed the derivation of the Court of Common Pleas as represented in the chart to stand, though it is not in accordance with the suggestion made in note $\mathbf{A}$ at the end of chapter III., because that suggestion is put forward for the present as a conjecture merely. If it proves to stand the test of examination the line of the common pleas should branch off from the line of the justices in eyre.

${ }^{3}$ Reference should also be made to a chart of the descent of French institutions, which has special reference to the various roval councils, published by M. Noël Valois in Le Conseil du Roi aux XIVe, $X V \mathrm{e}$, et XY'Ie Siècles (Paris, 1888). 


\section{ORIGIN OF THE ENGLISH CONSTITU'TION}

to kcep in mind, more clearly than does Mr. Pike's. This is its only special value.

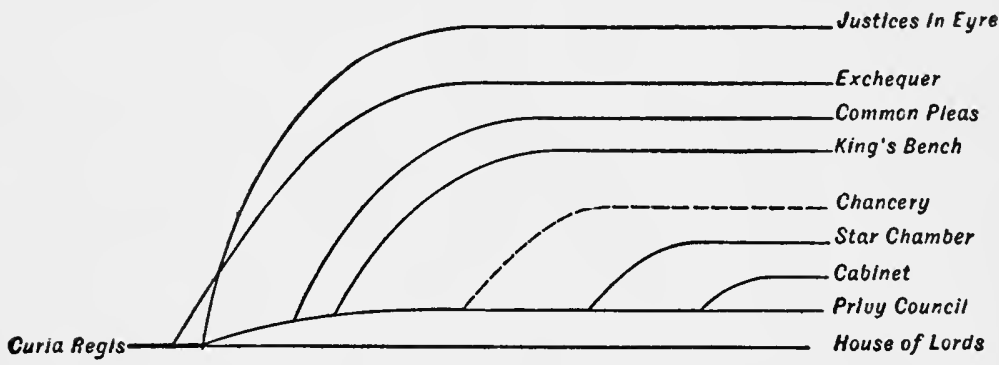

To understand English constitutional history, particularly the more puzzling features of it, there are two things which must be seen clearly at the beginning and never lost from sight. The first of these is the position of the curia regis in the feudal state - the fact that the feudal government was simple and undifferentiated and that the general organ of that government, the organ for everything not merely local, was the curia regis. All those functions which we are accustomed to assign in the modern state to different institutions, or sets of officials, were exercised in the feudal state by the curia without consciousness of difference or any attempt at distinction. I am accustomed in my instruction to emphasize three general functions as especially defining the business of the curia-legislative, judicial, and conciliar. ${ }^{4}$ The point which it is of the greatest importance to understand clearly at the start is that these three functions, which we should call distinct, were exercised without distinction by the one institution, the curia regis. As I have said elsewhere: "In a single session of the court, advice might be given to the king on some question of foreign policy, and on the making

4 For completeness, the function of the curia in reference to the administrative system should also be included, and Mr. Pike's chart brings out as mine does not the relation of these institutions in later times to the others which were derived from the common source. 


\section{APPENDIX}

or revising of a law ; and a suit between two of the king's vassals might be heard and decided: and no one would feel that work of different and somewhat inconsistent types had been done. One seemed as properly the function of the assembly as the other."

The second fact which must never be forgotten is the existence of the curia regis in two forms. The fact is so peculiar according to modern ideas that it is difficult to describe it in language which is at the same time accurate and sufficient to convey an understanding of the case. The curia regis was constantly in session under one or the other of two forms, never at the beginning apparently under both at once. One is the great curia regis, called after a time magnum concilium, meeting occasionally only, on special summons, and composed of all tenants-in-chief, lay and ecclesiastical, who might be summoned, and the great officers of state and of the household, who undoubtedly in early times would all be included also among the tenants-in-chief. The other is the small curia, practically in constant session when the other was not, called, when men began to distinguish it somewhat clearly from the other, the perpetual, or ordinary council, and composed of the royal officers, and of tenants-in-chief who were in attendance on the king, or might happen to be at court. The point of importance and of difficulty is not the composition or the meeting of the smaller curia, but the fact that it was in rights, powers, and functions, the larger. It was not a committee of the larger, its powers were not vested in it by the larger, it was not responsible to the larger; it was the larger. Whatever the larger might do the smaller might do, and the three functions which $I$ have named as belonging to the curia regis in the feudal state were exercised by it under both forms alike.

These then are the two essential things to have clearly in mind in beginning to study the constitutional history of England: that all the functions of the state were exercised by a single institution, and that that institution existed under two forms which 5 The Political History of England, vol. II. (1905), p. 182. 


\section{ORIGIN OF THE ENGLISH CONSTITUTION}

were distinguished from each other only by size and manner of meeting. Now the process by which the modern constitution has been formed from this simple feudal state was that of differentiation-first, the setting off of a particular sort of business into a class by itself, for mere convenience sake, then the assignment of certain men belonging to the curia to have the special duty of looking after that class of business. So gradually a cleavage took place which after a time gave rise to a separate institution. In this way one institution after another was thrown off from the original curia, the differentiation following always the general lines of function. It should be noticed also that it was from the small curia in all cases that the splitting off occurred. This is natural, for the fact that it was in constant session put into its hands particularly the carrying on of government.

What the first differentiation was, I believe no one can say with certainty, but I am inclined to think that it was a tendency to set off by itself the financial business which we know as exchequer business. However this may be, the differentiation which is fundamental and which has the largest influence on later history is that of the smaller from the larger curia regis. As the formation of two distinct institutions, generally recognized as such, this took place only during the thirteenth century, but we may fairly say that it began when men began to notice that the curia existed under two forms. We probably can detect this fact in written evidence no earlier than the reign of Henry I. ${ }^{6}$ I have endeavoured to represent on the chart the two as going on side by side and united till about that time, and then beginning to separate and, from a later point, from some time in the thirteenth century, rather before the separation of the chancery system, as running down to the present along two parallel lines.

6 To me it seems impossible to suppose that the curia did not exist in these two forms in the earlier reigns, and probably back to the very beginnings of this form of political organization. Whether this can be proved or not, is another matter. 


\section{APPENDIX}

At this point must be emphasized the fact that both divisions alike carried on permanently the three functions of the original curia. Circumstances tended in each line to emphasize one of these functions, to subordinate another, and to dwarf almost out of existence a third, but all three belonged equally to each institution after the separation. The union of new, representative elements with the magnum concilium to form Parliament, threw the emphasis in that line upon the legislative, but the House of Lords continued to exercise the judicial function, though it did not share it with the House of Commons, which could inherit nothing from the curia regis. ${ }^{7}$ The separate conciliar function practically disappeared, though not as the right of the individual peer, nor would its exercise by the House of Lords at any time in the past have seemed a straining of the constitution. ${ }^{8}$ Along the other line it was the conciliar function which was naturally emphasized, the judicial remained, but in a subordinate place, and the legislative became insignificant, the modern orders in council bearing scarcely a trace of the source from which they came. It is only by having this fact clearly in mind that we can understand the reason for such seeming anomalies in the English constitution as the process of impeachment, and the existence of two supreme courts of appeal, the one, the House of Lords, primarily a legislative body, the other, the judicial committee, a part of the king's council.

A third differentiation began, as I think probable, at about the same time as the two already mentioned, though it was not put into permanent form until later, ${ }^{9}$ that of the justices in eyre, intended at the start merely to exercise in local districts, instead of at the king's court, for convenience and greater efficiency, both

T That the judicial power of the House of Lords was exposed to some danger in the thirteenth century from the derelopment of royal justice, and in the fourteenth from some confusion of mind on the part of Parliament, are no doubt facts, but neither affected the final result in the least.

8 The action of the Lords, called by Charles I. to meet separately on September 24,1640 , at York, is very nearly if not quite a case.

${ }^{9}$ See Appendix II. 


\section{ORIGIN OF THE ENGLISH CONSTITUTION}

administrative and judicial functions of the curia. ${ }^{10}$ The itinerant justices' court was a session of the curia held locally. By degrees the administrative functions, which these itinerant courts had exercised in the counties, came to be better performed by other institutions which had in the meantime been developing, and they gave themselves up more and more exclusively to their judicial work, but unimportant relics of the old administrative functions of the curia regis may still be found in the operation of these courts in England, and of their American representatives, our circuit courts. II I have made the line which represents the derelopment of the Exchequer court to cross the line of these courts, and brought it into close relation with those of the other common law courts, because in my use of this chart I have emphasized the judicial development and paid little attention to the administrative. Of the three common law courts, I think I have placed about correctly the time and chronological order of their evolution, but it is impossible to indicate on a chart the fact that they were brought into existence by the continuous operation of the same principle.

The separation of the chancery system from the council I hare shown by a broken line because, while the jurisdiction of the chancellor was a jurisdiction belonging to the council, developed by it, and derived by the chancellor from it, the chancellor never exercised that jurisdiction himself in or through the council, but only outside it, as more or less of a usurpation, an absorption at least of a function not originally pertaining to him. The function, however, just as truly belonged to the curia regis as did that which fell to the common law courts. The Court of Star Chamber is always a difficulty to the beginner in constitutional study. The origin and right of its functions, its institutional standing ground, and the ease with which such a seemingly

10.Mr. Pike's chart distinguishes the justices of assize from the justices in eyre, and this should of course be done in any detailed study.

11 As for example when the judge instructs the grand jury to report upon the way in which the jail has been kept by the sheriff since the last session of the court. 


\section{APPENDIX}

anomalous piece of machinery was set up and operated, with no sense of anything revolutionary or unusual, are found puzzling. It is most easily understood, as is the historical ground of a separate chancery system, when it is carried back to the original curia and its relationship to that institution is made clear.

The last differentiation which I notice is that of the cabinet, but this is of so peculiar a character as to give rise to a problem for the maker of a chart. Historically it is clearly an off shoot of the council and should be so represented. But it has now absorbed the whole conciliar function of the old curia, and left the Privy Council existing, so far as real business goes, only in committees. Should it not be the ending of the main line instead of an off shoot? Again the cabinet has brought together in its hands functions which make it, startlingly for modern times, a reproduction of the old smaller curia. Control of the administrative system belongs to it. Its relation to Parliament almost makes it a legislative body. It has been called a third house. Only the judicial function is lacking. A comparison of this sort brings out clearly the position of the cabinet in the modern constitution, but it is quite as easy to show historically that it derives from its line of descent only one of these functions, the conciliar, and that its administrative and legislative responsibilities have come to it from other sources. 


\section{APPENDIX II}

\section{Henry I.'s Writ Regarding the Local Courts ${ }^{1}$}

The text of Henry I.'s writ regarding the local courts, published by Dr. Liebermann in his Gesetze der Angelsachsen, I. 524 , presents it in a form which renders its interpretation easier than the older text printed by Stubbs in his Select Charters, p. $104 .^{2}$ For convenience Dr. Liebermann's text is given here:

Henricus Dei gratia rex Anglorum, Samsoni episcopo et Ursoni de Abetot et omnibus baronibus suis, Francis et Anglis, de Wirecestrescira salutem! Sciatis, quod concedo et precipio, ut amodo comitatus mei et hundreta in illis locis et eisdem terminis sedeant, sicut sederunt in tempore regis Eadwardi; et non aliter. Et nolo, ut vicecomes meus, propter aliquod necessarium suum quod sibi pertineat, faciat ea sedere aliter. Ego enim, quando voluero, faciam ea satis summonere propter mea dominica necessaria ad voluntatem meam. Et si amodo exurgat placitum de divisione terrarum vel de preoccupatione, si est inter dominicos barones meos, tractetur placitum in curia mea. Et si est inter vavasores alicuius baronis mei honoris, tractetur placitum in curia domini eorum. Et si est inter vavasores duorum dominorum tractetur in comitatu. Et hoc duello fiat, nisi in eis ramanserit. Et volo et precipio, ut omnes de comitatu eant ad comitatus et hundreta, sicut fecerunt in tempore regis Eadwardi; et non remaneat propter aliquam pacem meam vel quietudinem, quin sequantur placita mea et iudicia mea, sicut tunc temporis fecissent.

A simple reading of this writ shows that it falls into two distinct parts. The first, down to the sentence beginning $E t$ si amodo exurgat, deals with what has been commonly called "the restoration of the ancient courts."3 Restoration is a somewhat

1 From the American Historical Review, VIII. 487-490.

2 In the original article printed from Liebermann, Quadripartitus, p. 165. For the text see also Hist. MSS. Com., XII., App. IX., p. 119.

${ }^{3}$ See Stubbs, Cons. Hist., I. 425; Liebermann, Trans. Royal Hist. Soc. 


\section{APPENDIX}

ambiguous word. It may mean no more than that the courts had fallen into disorder in the matters of time and place, or it may mean that they had fallen into decay and disuse, and so needed to be restored as a system. It is evident, I think, from the language of the writ that only the first can be meant. The writ shows clearly that these courts have been meeting constantly, indeed it would seem to be implied that they have been meeting too often, and this inference is strengthened by the form of statement in the Leges Henrici, VII. $1,{ }^{4}$ where this writ is referred to (nec ullis ultra fatigacionibus agitare nisi propria regis necessitas . . . .). The practice against which this order is especially directed would seem to be the abuse of his position by the sheriff to order the meeting of the local courts at unusual times and places for some purpose of his own. This must now cease, but the king seems to say, to paraphrase the last sentence of this part of the writ: "I cannot promise that extra sessions of the courts will never be called; some necessity really affecting the state may arise which will make them necessary, but if such a case occurs I will see to it that sufficient notice is given to reduce the inconvenience to the smallest possible."

The second part, which follows this sentence, gives rise to suggestions which seem to make it, institutionally considered, much the more important portion of the writ. It will be readily seen that this part concerns three things: (1) what courts shall have jurisdiction in certain cases; (2) a question of procedure in these cases; (3) attendance at the local courts. It is with the first of these points that question immediately arises. Three kinds of cases are mentioned, all concerning land held by feudal tenure. We should expect them to be tried in a feudal court and by feudal law. The first two kinds of cases mentioned call for no comment. A case between two vassals of the king goes into his court; one between two vassals of the same mean lord goes into his court, as we should expect. But the third strikes N. S., VII. 93; "rétablissant les cours de comté." Bémont. Rev. Crit. Hist. et Lit., XXXIII. 469.

4 Stubbs, Select Charters, 105. 


\section{ORIGIN OF THE ENGLISH CONSTITUTION}

us with some surprise. A case between the vassals of two different lords goes into the county court. To order a case involving feudal law out of a feudal court into the old local popular court would hardly seem to be possible. Either of two different dispositions of the case would seem to be more natural: that the case should be tried in the court of the defendant, see Leges Henrici, c. XXV., or that it should be tried in the court of the first overlord common to both, which in almost all cases at least would be the court of the king, see Constitutions of Clarendon, c. IX. A suggestion for the solution of this difficulty comes from the Constitution of Conrad II., of 1037. The second paragraph of that document, after providing for the carrying of certain cases directly to the king, closes thus: Hoc autem de maioribus walvassoribus observetur. De minoribus vero in regno aut ante seniores aut ante nostrum missum eorum causa finiatur. If the king's missus, his special commissioner, is present the local court becomes the king's court and the disposition of the case made by the writ is entirely regular. Can we go so far as to say that this writ gives evidence of the existence of itinerant justice courts as early as 1111, regularly organized to such an extent at least as to be taken for granted?

The second point of this part of the writ, the point regarding procedure, appears to bear directly on this question. Cases of this sort are to be decided by the duel, unless for some special reason it is omitted. It would seem as if the king's meaning might be stated as follows: the case is to go into the county court, but there need be no fear that this subjects it to the old Saxon methods of trial; the court is the king's, not the old popular court, and the Norman method of trial is preserved. If this interpretation is correct, the sentence implies that this arrangement was not entirely new, but had been of long enough standing at least for this question of procedure to arise and to make it seem to the king advisable to give it a formal answer.

The last sentence of the writ, that which concerns attendance at the local courts, seems to get in this way its most natural interpretation also. Its essential point is that no liberties or immu- 


\section{APPENDIX}

nities are to excuse from attendance when king's pleas are to be tried, that is, when the king's justice is present, exactly the later regulation for the itinerant justice court in the county. If we turn again to the passage in the Leges Henrici, c. VII., which a few years later made use of this writ and enlarged upon it, we find some confirmation for this interpretation. VII. 2 states the composition of the county court in terms which, while different in detail, remind us strikingly of those used in the writ of Henry III., of $1231,{ }^{5}$ which is usually used as typical of the composition of the county court which met the itinerant justices in the thirteenth century, and they appear to include the same classes with the possible exception of the burgesses. It is hardly possible to suppose that this is the everyday shire court under the sheriff, acting merely as sheriff. ${ }^{6}$ The presence of the bishop is particularly noteworthy. If the ordinary interpretation is to be given to the writ of William I. separating the spiritual and temporal courts, the presence of the bishop in the ordinary county court would not be easy of explanation. ${ }^{7}$ If this is a king's court held in the county, his presence is natural and to be expected. This interpretation is rendered almost necessary by the first words of VII. 3: Agantur itaque primo debita veræ Christianitatis jura; secundo regis placita. This court, whatever it is, tries cases which affect the church. Apparently we must conclude that this is a king's court, in which case the statement presents no difficulty; or we must modify in a very decided way our understanding of William's legislation on this point, an alter-

5 Stubbs, Select Charters, p. 358.

6 This would seem to be the probable conclusion also as to the regis judices of Leges Henrici, c. XXIX.

IIn William's writ (Stubbs, S. C., p. 85), the specific reference is to the hundred, but the word is plainly used in a generic sense. As the most frequently used court, the hundred may well stand for the whole body of law and procedure of the popular courts. In these respects the shire court was identical with the hundred, and it would not be possible to remove ecclesiastical cases from the system of law and procedure belonging to the hundred courts without taking them at the same time out of the shire courts. See Liebermann, Gesetze, I. 485, $d$, e. 


\section{ORIGIN OF THE ENGLISH CONSTITUTION}

native which is not easy in view of the clearness of the language in which that is expressed.

In this article as originally published, I supposed that the case referred to in Glanvill, XII. 8, similar in principle to that of the vavasores duorum dominorum and seeming to go directly to the county court, should be allowed some weight against my conclusion. I am now of the opinion that this was an error, and that the cases falling under Glanvill, XII. 8, went to the sheriff per breve domini regis like those of default of right. The sheriff seems to have been called justitia regis in the reign of Henry $\mathrm{I}^{8}$ We can, however, say no more than that this writ of Henry I. gives some evidence that the county court was used as early as this date as the basis of a local king's court with a composition similar to that of the later itinerant justice court, and like it suspending the immunities granted by charter from attendance at the ordinary local courts. If not the itinerant justice court itself, the county court of this writ is its forerunner and furnishes the foundation on which that system was erected at some later date, perhaps in the same reign. As a matter of probability, it is likely that this was occasionally an itinerant justice court from the beginning, and occasionally a sheriff's king's court, and that a regular system of itinerant justices was reached only gradually. I would not, however, insist too strongly on any conclusions from a course of reasoning based on so slight a body of material, and $I$ have endeavoured throughout to suggest rather than to affirm, but the problem which this material presents is an interesting one and deserving of attention, when the scanty sources for our knowledge of the judicial organization under Henry I. are studied.

${ }^{8}$ See Stubbs, I. 420, n. 1, and Liebermann, Leges Edwardi Confessoris, p. 73 . 


\section{APPENDIX III}

\section{London and the Comuune ${ }^{1}$}

THE word "commune," as is well known, was used in the Middle Ages, like many words in the feudal vocabulary, both in a vague, popular sense and in one strictly defined and technical. In the former sense it might be applied to any union of citizens for the purpose of securing freer conditions of local government; in the latter it was applied only to a town that was formally constituted in its corporate capacity a feudal person, a vassal of its lord, a lord perhaps of other vassals, with the rights, obligations, and freedom of that station in the feudal society, a seigneurie collective populaire, as it has been termed by Luchaire. ${ }^{2}$ That London was called a commune in the former sense has long been known. ${ }^{3}$ The most interesting of the early instances of the fact is the passage in William of Malmesbury, where, in recording the events of 1141 , he mentions omnes barones qui in eorum communionem iamdudum recepti fuerant. ${ }^{4}$ The question whether London was ever a commune in the stricter sense has been raised by Mr. J. H. Round in connexion with the events that occurred there in 1191 and the light thrown on them by two documents of a little later date which he has printed for the first time. ${ }^{5}$ The language of the chroniclers in describing the occurrences of 1191 clearly indicates that with reference to a commune of London something unusual was done, some step was taken that had never before been taken. ${ }^{6}$ The language of

1 From the English Historical Review, vol. XIX. 702-706.

2 Communes Françaises, p. 97.

3 Stubbs, Const. Hist., I. 407, first ed.

4 Hist. Nov., c. 495.

5 The Commune of London, and other Studies (1899), pp. $219 \mathrm{ff}$.

6 The passages of chief importance are these: "Johannes comes frater regis et archiepiscopus Rothomagensis, et omnes episcopi, comites, et 


\section{ORIGIN OF THE ENGLISH CONSTITUTION}

Richard of Devizes admits of no other interpretation, and, while it is perhaps possible that he might have used the same language of a concession of local independence to London which would fall considerably below a strict commune, the reference to Richard and Henry and the mention of the oath taken to the commune by John, who probably assumed to be acting for the crown, make such an interpretation unlikely. The most natural supposition is that John granted to London the position of a crown vassal with all the privileges which that would carry with it. As, however, this interpretation of the language of Richard of Devizes is not beyond question, and as our evidence from the following period leaves the status of the city somewhat in doubt, it is worth while to analyze such evidence as we have to see if the doubt can be removed.

1. In 1894 in his Leges Anglorum, Dr. Liebermann called attention to the fact that Addit. MS. 14252 of the British Museum gave evidence of the existence of a mayor and skivini in London under Richard and John.? The documents which embody this evidence, important in themselves, are those referred to above as published by Mr. Round in his Commune of London. Mr. Round's essay seems to imply that he regarded the conclusive proof that he presented of the existence of these officers in London as equally proof of the establishment of a commune by the act of 1191 as something different from the earlier commune in the vague sense, but it is certain, I think, that neither mayor nor skivini were officers typical of the commune in the technical sense. They existed in towns not recognized as legally

barones regni qui aderant, concesserunt civibus Londoniarum communam suam, et juraverunt quod ipsi eam et dignitates civitatis Londoniarum custodirent illibatas, quamdiu regi placuerit" (Gesta, II. 214).

"Concessa est ipsa die et instituta communia Londoniensium, in quam unirersi regni magnates et ipsi etiam ipsius provinciæ episcopi jurare coguntur. Nunc primum in indulta sibi conjuratione regno regem deesse cognovit Londonia, quam nec rex ipse Ricardus, nec prædecessor et pater ejus Henricus, pro mille millibus marcarum argenti fieri permisisset" (Richard of Devizes, Chronicles of Stephen, etc., III. 416).

' Leges Angl., pp. 18 and 83. 


\section{APPENDIX}

communes. ${ }^{8}$ And while the interesting evidence that Mr. Round presented in the same essay of the derivation of the London organization from Rouen makes the existence of a commune more likely it is not conclusive. Both Rouen itself and the towns that adopted its institutions were imperfect communes, allowing unusual powers to the suzerain, ${ }^{9}$ and it is quite possible that London might have borrowed these officers from Rouen without objection from the king and without obtaining therewith recognition as a crown vassal.

2. If John, even as representing the crown, granted a commune to London in the strict sense, it is by no means certain that Richard on his return would have felt himself bound by that grant. No act of royal prerogative is more common in the feudal age than the disavowal and revoking by one king of his predecessor's grants from the crown domain, at least when these have been made under circumstances which put the crown at a disadvantage, and the grant of a commune to London, legally considered, would be a grant frcm the crown domain. The words of Richard of Devizes seem like a well-informed judgment of what Richard's attitude in the matter would be, and our general knowledge of that king's character makes it seem unlikely that he would have hesitated to refuse his sanction to his brother's act.

3. This supposition receives some confirmation from the absence of all reference to a commune in the charter of Richard to the city of 23 April, $1194,{ }^{10}$ as well as from the use of the ordinary form of expression pro libertatibus suis conservandis in the entry in the Pipe Roll of $1195,{ }^{11}$ where the Londoners' payment of 1000 pounds to the king is recorded. The conclusion is fairly certain that Richard recognized no commune, for

${ }^{8}$ Luchaire, Communes, p. 176; Manuel des Institutions Françaises, pp. 404-405.

${ }^{9}$ Luchaire, Manuel, p. 402 , n. 1; Communes, p. 102.

10 Liber Custumarum, p. 248.

11 Commune of London, p. 234; cf. Madox, I. 473, n. $t$ (p. 327, n. $t$, ed. 1711). 


\section{ORIGIN OF THE ENGLISH CONSTITUTION}

it is hardly possible to suppose that a relationship to the crown so exceptional so far as English towns are concerned, would have escaped some kind of notice had it existed. In line with this are John's charter of confirmation of $17 \mathrm{June}, 1199,{ }^{12}$ and his grant of the shrievalty to the citizens on 5 July of the same year. ${ }^{13}$ The citizens might indeed hare wished to buy the shrievalty even if they had had a commune, for, embracing the county of Middlesex, it would be wider than the commune; but it may rightly excite suspicion because, with a commune in the strict sense, their interest in the shrievalty would be greatly reduced.

4. From 1215 comes a piece of evidence interesting in the suggestion it makes but exasperating in its incompleteness. ${ }^{14}$ In the charter of $9 \mathrm{May}$, which John issued to the city as his trouble with the barons was approaching a crisis, the mayor is required to swear allegiance to the king. If we had a record of the form of oath to be taken by the mayor under this charter, it is quite likely that our problem would be solved, so far at least as this particular date is concerned. If he took an oath of fealty to the king in the name of the city, and as representing it in its vassal capacity, London was a commune; if he took it merely as an officer of the city, the same oath which other officers took at the same time, it was not. The language of the charter looks like the former case, and suggests that the king may be tempting the city with the hope of a restoration of the commune to which he had once sworn, but not so clearly as to exclude the other possibility.

5. Clause 12 of Magna Carta has the appearance of deciding the question. London is there classed with the crown vassals, and its tax payments are called auxilia. A comparison of this clause with clause 32 of the Articles of the Barons shows, I think with great probability, that this exact point was clearly in mind and that the language was used intentionally. The earlier

12 Rymer, I. p. 76; cf. charter of Henry III., Lib. Custumarum, p. 45. ${ }^{13}$ Ibid., p. 249 ; cf. E. H. R., XVII. 508.

1 See Miss Bateson in E. H. R., XVII. 726. 


\section{APPENDIX}

article says: Simili modo fiat de taillagiis et auxiliis de civitate Londoniarum, et de aliis civitatibus quæ inde habent libertatesevidently a careless phrase and an extension of the privilege that could be justified legally by no precedents in favour of the towns included. To have inserted it in the final charter would have been to demand a large concession from the crown, and to demand new grants is not in the general spirit of Magna Carta. The demand for London might be justified if John himself had once sworn to its commune, but there were no grounds on which it could be claimed for any other town. As Magna Carta in general, and in comparison with the Articles of the Barons, is a carefully drawn document, this explanation of the difference between the two clauses is not improbable. It seems possible then to conclude that in clause 12 of Magna Carta the crown, in indirect terms at least, recognized London as a commune in the strict sense. ${ }^{15}$

6. The first piece of evidence that is conclusive comes to us from the reign of Henry III. and from his thirty-ninth year. In that year, according to the record of the case then made, ${ }^{16}$ the king by order of the council ordered a tallage of his domains to meet the expenses of his campaign abroad. As a part of the domain the citizens of London were summoned before the king and council and informed that 3000 marks was asked of them, nomine tallagii. The mayor and others who had appeared for the city took counsel together and offered 2000 nomine auxilii, and declared flatly (pracise) that they could not and would not give more. Then the king sent his treasurer and others of the council to London to receive the sum demanded, with instructions, if the city would not pay it, to assess it themselves upon the citizens individually; but the king's messengers found not merely

15 A grant of freedom from tallage merely would not be equiralent to the grant of a commune, nor evidence of its existence. Clause 12, however, seems clearly to class London with the vassals of the crown, and the payment of auxilia seems to be claimed as a right rather than asked as a concession.

16 Madox, Exchequer, 1. 712 , n. $a$ (p. 491, n. $a$, ed. 1711). 


\section{ORIGIN OF THE ENGLISH CONSTITUTION}

that the city refused to pay the tax, but that the citizens refused to take the oaths demanded of them to fix the assessments of one another, and they had to go away infecto negotio illo. Then the matter came before the king's council at Westminster on the issue of fact created by the claim of the city. Et cum contencio esset, utrum hoc dici deberet tallagium vel auxilium, rex scrutari fecit rotulos suos, utrum ipsi aliquid dederunt regi vel antecessoribus suis nomine tallagii. Et scrutatis rotulis compertum est tam in rotulis de scaccario quam de Cancellaria that in the 16 th of John and in the $7 \mathrm{th}, 26 \mathrm{th}$, and $37 \mathrm{th}$ of Henry III. the city had been tallaged and had paid the tax. That settled the case. Postea in crastino venerunt prædicti Radulfus maior et cives et recognoverunt se esse talliabiles, et dederunt regi tria millia marcaram pro tallagio. Now both tallagium and auxilium are words used in a vague as well as in a technical sense, but it is not possible to suppose that anything but the strict technical distinction between them is here meant by the claim which London advances. The city asserts that it is not a part of the king's domain, that it should pay auxilia, like a vassal, and not tailagia, like a villain. The precedents are examined; they prove to be clearly against the city-if the council had had a copy of Madox's Exchequer they could have increased the number; - and the city is obliged to withdraw its claim and to confess itself a domain town. The bearing of the case is so clear, indeed, that we cannot believe that the crown as such had ever recognized London as a true commune, not even as a consequence of the act of John in 1191, or that the claim of London in Magna Carta had been made good.

In view of all the evidence, I am inclined to suggest these conclusions: John in 1191, assuming to represent the crown, granted to London a commune in the legal sense and under this arrangement the mayor and skivini constitution was introduced. Richard, on his return, refused to confirm this grant, though this refusal did not modify the city's constitution, and John as king continued Richard's policy. In 1215 he needed the city's support and bid for it with the charter of $9 \mathrm{May}$, in which it is possible, though only barely possible, that he meant to hold out the 


\section{APPENDIX}

prospect of a re-establishment of the commune. In Magna Carta a few weeks later the city put forward its own programme, with the support of the barons asserted its legal right to the commune, and compelled the king to recognize it, hoping in this way to establish it. On the reissue of the charter after the death of John, clause 12 was omitted and with it London's legal right to a commune fell to the ground..$^{17}$

$\mathrm{In}^{18}$ one of the supplementary studies appended to his translation of Stubbs's Constitutional History, ${ }^{19}$ M. Petit-Dutaillis has published a criticism of the views expressed above. His argument against my suggestions is founded on the generally vague and untechnical use of terms in the feudal age. On this point, I quite agree with my critic. A tallage proper is called a tallage, an aid, a donum, or an assize. An aid proper is not so often called by another name in the documents, still it is occasionally referred to as a scutage, or a donum, and by the chroniclers is even called a tallage. ${ }^{20}$ So general is this indefiniteness of usage that $I$ doubt if we are justified in assuming a technical meaning for any such term unless we can show from the context or from the facts of the case that it is so used. But in studying feudal documents it is important to bear in mind that though the men of that age often used their terms untechnically, they did not confuse their

${ }_{17}$ Possibly the reference to London, along with that to scutage, was one of the dubitabilia said in the reissue of 1217 to have led to the omission of that clause. We must regard its insertion in the clause, I think, as an assertion of London's claim and programme, and not of a legal right that the crown was likely to admit.

18 The following is from a supplementary note in the English Historical Review, vol. XXIV. 490-495.

${ }_{19}$ Paris, 1907, pp. 846-860; in the English translation of these Studies by Mr. W. E. Rhodes (1908), pp. 91-106. References are here given to the translation.

${ }^{20}$ Dominus Henricus rex Angliæ accepit tallagium per Angliam, tam a comitibus quam a baronibus, militibus, viris religiosis civibus et burgensibus: Ann. Monast., I. 97. This aid of 1235 to marry the king's sister is called in the king's writ both an auxilium and a scutage, Stuhbs, $S . C$., p. 364; and by Matthew Paris a carucage, III. 327, and a scutage, IV. 186. An aid is called a tallage in Bracton's $N$. B., case 895 . 


\section{ORIGIN OF THE ENGLISH CONSTITUTION}

facts. When they were calling a tallage proper an aid, they knew the difference between the two things, and distinguished them sharply, or used their language technically, if the need arose. ${ }^{21}$ In the present case opinion must, I think, be determined by the question whether cuxilium in c. 12 and in the document of 1255 is used technically or not. My contention is that in 1255 at least that is what was intended, and that this fact lends support to such an interpretation of c. 12.

M. Petit-Dutaillis supposes that I overlooked the following passage in the Dialogus de Scaccario in which he believes the word auxilium, in the case of the second alternative, to be used in the same sense as by the Londoners in 1254. The passage is: $:^{22}$

Noveris itaque quod plurimum interest si donum, vel auxilium, civitatis per singula capita commorantium in ea a iustitiis constituatur, rel si cives summam aliquam, que principe digna videatur, iustitiariis offerant et ab eis suscipiatur. Dispar enim in hiis duobus modus est cohercionis. Si enim per singulos a iudicibus constitutum est donum et quilibet eorum solvendo non fuerit, lex predicta de civibus non solventibus servatur, ut scilicet domibus et redditibus usque ad solutionem privetur. At si dictum est a civibus "Dabimus regi mille" et hec summa digna suscipi judicetur, ut statutis terminis eadem exurgat, ipsi provideant.

I will confess that the support which this passage gives to my interpretation of the document of 1255 seemed to me so obvious that I did not think it necessary to point it out. But I will now

21 Villata de Wicumba debet $\mathrm{xx} l$ et viii $d$ de taillagio. Sed consideratum est per iusticiarium et barones, quod manerium illud non debet tailliari, quia inde facit Alanus Basset servitium militare, sicut continetur in carta ipsius: Pipe Roll, 1 John, Madox, I. 74.5, n. $b$ [p. 513, ed. 1711]. See the claim of the Banaster Welshmen, Shirley, Royal Letters, 1. 349. Bracton's $N$. B., case 1005, distinguishes the two, though both are called auxilium. The distinction in the matter of consent is clearly drawn in the two writs in favour of Richard of Cornwall, dated 29 October, 1259, Rymer, I. 391. Bracton has naturally little to say of tallage, but he marks it off sharply from the aid; cf. ff. 26 and 36 b [ed. Twiss, I. 206 and 286-288]. The prelates distinguished clearly enough between a scutage and an aid in 1229, Madox, I. 607, n. $z$ [p. 422, ed. 1711]. See also ibid., I. 673 [p. 467, ed. 1711].

22 Dialogus, II. 13, ed. Hughes, Crump, and Johnson, p. 145. 


\section{APPENDIX}

analyze the passage with care. The author of the Dialogus calis the payment of which he is speaking donum or auxilium civitatis. In regard to it he describes two processes which are alternatives of one another. In the first, the so-called auxilium is clearly assessed per capita upon the inhabitants of the town by the king's justices. It needs no argument to show, nor do I think any one would doubt, that this is the tallage proper as opposed to the auxilium proper: that is, to the voluntary aid of the feudally free man. The question concerns the other alternative, Does it make a difference in the nature of the tax? Now it is plain from the passage quoted, and from the tenor of the whole chapter in which it occurs, that the author is mainly interested here in methods of distraint for non-payment. He says that the method of distraint is different according as one or the other altcrnative is used in what he calls alike in both cases the auxilium civitatis. $\mathrm{He}$ describes the alternatives merely to makc clear the methods of distraint; he is not concerned at all to explain their effect on the nature of the tax. We are compelled therefore to reach our own conclusions on that subject by inference. The second alternative is that the citizens offer the justices a lump sum and, if the off er seems to them worthy of the prince, that is, sufficient for the occasion, they accept it and the citizens themselves become responsible for the payment at the appointed terms. What is it that the citizens buy by their offer? What change do they make by it in the process of the first alternative? It seems to me clear that they buy off the assessment per capita with the resulting method of distraint, and that only. It is not the arbitrary fixing of the tax. They do not determine the sum to be paid. If the offer does not seem to the justices large enough, the citizens must raise it until the sum is judged to be a fair equivalent for what would be obtained from an assessment per capita. But it may be said that the payment of the citizens in this second case is voluntary, and that I understand to be the interpretation on which M. Petit-Dutaillis bases his reasoning. Something is voluntary certainly, but is it the fact of payment? If the citizens refuse to pay a lump sum, will the king receive nothing, as would 


\section{ORIGIN OF THE ENGLISH CONSTITUTION}

be the case in the auxilium proper? Certainly not. In that case recourse is had to the first alternative and the assessment is made per capite, as in the passages quoted below from the document of 1255. All that is left to the decision of the citizens is whether they will buy off the assessment per capita or not. In technical terms this is the process of the "fine." The citizens "fine with the king" for the privilege of making their own assessment. The subject could fine with the king for an alleviation in the process or incidence of practically any right or privilege of the king, but such a fine made no change in the character of the king's right or of the subject's obligation. ${ }^{23}$

Now in the document of 1255 , the alternatives which the king offers the Londoners are the alternatives of the Dialogus. This is the passage $:^{24}$

23 Thus: Mandatum est assessoribus tallagii in comitatu Oxoniæ, quod si burgenses Oxoniæ, qui offerunt eis ad opus regis $\mathrm{C} m$ pro tallagio villæ suæ, dare voluerint $\mathrm{C} l$ pro tallagio burgi et suburbii Oxoniæ inde sint contenti pro tallagio illo: Fine Roll 18, Henry III., Madox, Exchequer, I. 743, n. $p$. [p. 511, ed. 1711]. Homines Wintonæ $r$ c de ccce $m$ de fine suo quem fecerunt pro dece $m$, quas $S$. de Turneham talliaverat super eos: Pipe Roll 4, John, ibid. n. m. The following shows what it is that the burgesses purchase, and what the word auxilium means: Homines de Hornecastra $\mathrm{r}$ c de xxix $l$ et xiii $s$ et iiii $d$ de auxilio eiusdem villæ, quod ipsi assederunt inter se concessu iusticiarum aliter quam iusticiæ: Pipe Roll 14, Henry II., Madox, I. 585, n. $w$ [p. 407, ed. 1711]; see also n. $u$. The difference in the process of distraint is illustrated by the quotation ibid., I. 740, n. $d$ [p. 509, ed. 1711]. The phrase "offerunt pro tallagio" is strictly correct. In full it would read "offerunt finem pro tallagio." It does not mean that a tax different in principle, but that a fine is offered for the tallage. In the document of 1255 , it was because the citizens of London recognized themselves as tallageable that they gave the king $\mathbf{3 0 0 0}$ marks for the tallage. Instead of "pro tallagio illo" as above we have in some documents, as in one of those quoted in 1255 , "pro tallagio ea" or "hac vice," which means that no precedent was established and no change made in rights or obligations. The evidence is so conclusive that it is impossible to consider the passage in the Dialogus as referring in either of the alternatives described to any form of taxation but the tallage.

24 Madox, I. 712, n. a. It will be noticed that what the king offers is 


\section{APPENDIX}

Et tunc rex de consilio suo misit Philippum Lovell thesaurarium suum, Henricum de Bathonia, Petrum de Rivalle, Rogerum de Thurkelby, et Edwardum de Westminstre, apud Sanctum Martinum ad recipiendum finem trium millium marcarum pro tallagio, si intrare vellent sicut eis prius dictum fuit; et si nollent, tunc assiderent tallagium illud in civitate per capita.

These are clearly the alternatives described in the Dialogus and they do not affect the kind of tax, but the method of assessment. But this is not what the Londoners desire. They wish a different kind of tax; they do not recognize either alternative as their auxilium, and on'their right to pay this they stand.

Et cum prædicti cives noluissent intrare finem prædictarum trium millium marcarum, prædicti thesaurarius et alii voluerunt assidere illud tallagium per capita, et quod quilibet iuraret catalla alterius. Et cum ipsi noluissent facere sacramentum, nec etiam dicere in fide qua regi tenebantur de catallis singulorum, dicti thesaurarius et alii inde recesserunt infecto negotio illo. Postea venerunt prædicti cives coram rege apud Westmonasterium die Dominica proxima post Purificationem B. Mariæ Virginis anno prædicto et coram consilio suo .... Et cum contencio esset, utrum hoc dici deberet tallagium vel auxilium, rex scrutari fecit rotulos suos, utrum ipsi aliquid dederunt regi vel antecessoribus suis nomine tallagii.

That they are drawing the technical distinction here seems to me to admit of no question. M. Petit-Dutaillis says it is because they wished to fix the amount of their tax themselves. Of that I have no doubt; but that is the technical auxilium, not the auxilium civitatis of the Dialogus. The Londoners join issue squarely between both the alternatives of the Dialogus on one side, and the auxilium to which they lay claim on the other. This is also clear in the result of the case, which seems almost like a law suit. The records are searched. Four cases are produced. In two of these the Londoners talliati fuerunt; in two dederunt pro tallagio: $:^{25}$

called a fine. I believe the language of this document throughout to be strictly and carefully technical.

25 That is, dederunt finem pro tallagio. That this is the proper reading in that one of the four cases taken from 26 Henry III. is certain. Under the date of 12 March of that ycar a mandate was issued to "the barons 


\section{ORIGIN OF THE ENGLISH CONSTITUTION}

the alternatives of the Dialogus again, and those of the king. In view of these four cases, not of the first two alone, the Londoners abandon their claim and acknowledge themselves tallageable.

M. Petit-Dutaillis says that the object of the Londoners was to get rid of the liability to arbitrary taxation fixed by the king, and to be able to determine the amount of their payments themselves. That this was their programme, both in 1215 and in 1255, is exactly what $I$ assert. ${ }^{26}$ But here arises the question of law. I

of London to deliver out of the $1000 l$. whereby they made fine with the king for the last tallage, $200 \mathrm{~m}$. to $\mathbf{P}$. bishop of Hereford, going as the king's envoy beyond seas, for his expenses. And the king sends to them his writ of computate for the said sum to the barons of the Exchequer", Cal. of Pat. Rolls, 1242, p. 275. Later in the same year the following record was entered on the Pipe Roll: "Cives Londoniæ reddunt compotum de $1000 l$. pro taillagio hac vice sicut continetur in originali $\times x v$. In thesauro decclxvi $l$, i $m$. Et Petro Hereford' Episcopo ad expensas suas ad partes transmarinas ducentas marcas per breve regis. Et quieti sunt. 26 Henry III., Lond. et Midd., Tit. Nova Oblata." For this quotation I am indebted to Dr. S. K. Mitchell. In view of this documentary evidence the account in Matthew Paris, IV. 242, which seems to describe a tallage assessed per capita in 1243, cannot be considered to refer to this tallage. Nor have I found evidence of any tallage levied in 1243. The statement of Paris must be considered, I think, rhetorical, indicating his general feeling about the king's exactions.

${ }^{26}$ If the document of nine articles discovered by Miss Bateson (E. $H . R$, XVII. 726) is, as she conjectures may be the case, a statement of what the Londoners would like, perhaps a petition to the king before the charter of 9 May, 1215, their programme is sufficiently clear. C. 3 of that document reads: "De omnibus taillagiis delendis nisi per communem assensum regni et civitatis." They failed to get this from John, however. The charter of 9 May represents the farthest that he was willing to go even in bidding for their support. M. Petit-Dutaillis is wrong in saying that c. 12 of Magna Carta is in my opinion a restoration of the commune by John "when he had need of the support of the inhabitants." On the contrary, my suggestion was that the charter of 9 May represents John's bid for support, but that c. 12 was the programme of the city forced upon the king with the help of the barons. M. Petit-Dutaillis asserts, p. 105, that the burgesses show no desire for the recognition of the commune. "They asked for nothing of the sort in the nine articles, or in the petition of the barons." I am not sure that they did, but if 


\section{APPENDIX}

know of no such right of the tax payer recognized anywhere in the feudal law except the technical aid of the feudally free man, and that was not an altogether perfect right. Nor do I know of any way by which the town ever reached that position, except as it became a commune, or, falling short of that, made some special arrangement with its lord covering this point. Unquestionably, as a matter of competence, the king could have granted to London an exemption from tallage and the right to grant its own aids, without making it a full commune, or indeed without granting it any further rights. ${ }^{27}$ But, however far such an alternative may be carried, it has no application, so far as we now know, to anything in the London case. The only incident to which we can refer their claim of 1255 for any historical justification is the apparent recognition by John in 1191 combined with c. 12 of Magna Carta. If they had any other ground on which to base their claim to pay aids only, and of their own fixing, the evidence of it has not come down to us. ${ }^{28}$ That the

either c. 3 of the nine articles or c. 32 of the Articuli Baronum were thrown into strictly legal statement we should have what is said in c. 12. In c. 7 of the nine articles, which reads, "De maiore habendo de anno in annum, per folkesmot, et quod primum iuret," the last clause should be noticed along with my suggestion above in regard to the oath provided for in the charter of 9 May. The interest shown in what the mayor was to swear certainly points to an oath of some not usual kind and may possibly indicate the mayor's oath for the commune.

27 In the charter granted by Henry to Rouen in 1150 , which was probably a confirmation of a grant of his father, Geoffrey, in 1144, c. 13 reads: Quod nec tailliam faciam super eos nec res eorum capiam, nisi sua bona voluntate prestare voluerint michi. Giry, Etablissements de Rouen, II. 58; cf. Round, Calendar of Documents preserved in France, p. 33. As to the date of this charter, and the fact that it does not establish a commune, see Giry, I. 25-26.

28 I understand M. Petit-Dutaillis to mean, pp. 103-104, that the towns were subject sometimes to aids freely granted by themselves and at other times to tallages. If language is used at all strictly, I do not think this can be correct. They were no doubt constantly paying fines and tallages, in the strict sense of these words, but is there any instance in which they were called on for an aid which was "in theory a gift made to the king"? The auxilia of the towns ad filiam regis maritandam and ad 


\section{ORIGIN OF THE ENGLISH CONSTITUTION}

Londoners in 1255 had in mind c. 12 of Magna Carta, or that they intended to claim a technical commune in 1215, I do not affirm; but I think that the two instances should be considered together, and in connexion with the incident of 1191 . That c. 12 was omitted from the reissues of Magna Carta and is not referred to in 1255 , I do not admit to be a matter of importance. ${ }^{29}$ But it seems strange that the Londoners should allow so long a time as the forty years between 1215 and 1255 to go by, during which they submit to so many tallages, only to raise the point after a whole generation has elapsed. ${ }^{30}$ If we could show a peculiar opportunity in 1255 which did not exist at an earlier date, the difficulty might be reduced.

regis redemptionem which appear in the Pipe Rolls are really tallages, on the well-known principle that when a feudal aid or scutage is received from the military tenants a tallage is taken from the demesnes. See Madox, I. 634, n. $q$ [p. 441, ed. 1711], extracts from the Pipe Roll of 33 Henry II., which are also interesting because of the clearness with which they show that donum and tallagium were interchangeable terms. If c. 12 of Magna Carta means what it says, and if London were in fact put into the position it describes, then, whether its previous payments are to be called aids or tallages, it would be put, so far forth, into the position of a crown rassal, for its free grants to the crown, if it had made any that were not fines, had surely not been made per commune consilium. The statement in p. 103, n. 1 , that the Londoners "had just paid in the year 1214-1215 a tallage of 2000 marks" is not quite accurate. The tallage had been laid in that year (talliati fuerunt), but the Pipe Roll of 6 Henry III., shows that it was not paid until some years later. (Quoted in Madox, I. 388, n. $f$ [p. 267, ed. 1711]).

${ }_{29}$ The legal case as a whole was naturally not entered in the Memoranda roll from which lladox quotes, but only such parts of it as might be thought necessary for reference. The continued remembrance of the omitted clauses of Magna Carta is too large a subject to be entered upon here, but evidence of it is certainly not lacking.

${ }^{30}$ If we can trust Matthew Paris, the interval is not quite so long. Under 1241 (IV. 95), he says: "Nec multum post, cives Londonienses contra consuetudinem et libertatem civitatis, quasi servi ultimæ conditionis non sub nomine aut titulo liberi adiutorii, sed tallagii, quod multum eos angebat, regi, licet inviti et renitentes, numerare sunt coacti." This seems to draw the issue sharply and can hardly be all rhetoric like the servi ultima conditionis. It may have been written after 1255, and 


\section{APPENDIX}

wrongly dated by Paris, but the printed text gives no evidence of this. For study of this passage, compare III. 381; IV. 182, 242, 395, 511; V. $50,333,486,536,568$. It was the tallage of 1241 for which the Londoners fined in 1242 . 



\section{INDEX}

Adsinistrative system, supervised by curia regis, $69,374 \mathrm{n}$.; by the itinerant justices, $132 \mathrm{ff}$., $145 \mathrm{f}$.

Advocatus, the, 245, 259.

Afforcement of a court, $197 \mathrm{f}$. Aid, the feudal. See Auxilium.

Allegiance, Norman reservation of, $98,105,186$ ff.

Amalric I., his assise sur la Ligèce, 105.

American constitutions, relation to the English, $41 \mathrm{f}$.

Anglo-Norman institutions, changes of the first century, $107 \mathrm{f}$;; effect of changes under Henry II., $134 \mathrm{f}$., $144 \mathrm{ff}$.

Anselm, Archbishop, 70; trial at Rockingham, 23 n., 68, $171 \mathrm{n}$.

Arms, Assize of, 191.

Articles of the Barons, 223, 225, 245, 256 ff., 262 .

Assembly, national, Saxon, 6; Frankish, 10; in Normandy, 12.

See Curia regis; Witenagemot. Assise sur la Ligèce, the, 105.

Assizes, the possessory, $126 \mathrm{f}$., $232 \mathrm{f}$; ; the grand assize, 127.

See Clarendon; Northampton; Utrum.

Auxilium, the feudal payment, 51, $222,228,229$ n., $253 \mathrm{ff}$; from rear vassals, $230 \mathrm{ff}$.; of London, $225,389 \mathrm{ff}$.

Auxilium civitatis, $393 \mathrm{ff}$.

$B_{\text {ARoN, the feudal, in the opera- }}$ tion of government, $\tilde{r} 0,144 \mathrm{f}$; his courts and private jurisdiction, 78 f., $90 \mathrm{ff}$.
Barons, major and minor, $214 \mathrm{n}$., 226 n., $323 \mathrm{n}$.; attitude of, towards changes of Henry II., 122, 128 f., 239 f.; inconsistency of, in Magna Carta, $128 \mathrm{f}$., $233 \mathrm{f}$.

Bath, the bishop of, 1121; trial of a case under a royal writ, in his court, 80 n., $118 \mathrm{n}$.

Becket, Thomas, 69, 115; form of summons to great council at Northampton, $226 \mathrm{n}$.

Bill of Rights, the, relation of, to Magna Carta, 253, $309 \mathrm{n}$.

Blackstone, Sir William, relation of the king to law in his Commentaries, $309 \mathrm{n}$.; on precedents of revolution, $312 \mathrm{f}$.

Bracton, Henry de, relation of the king to law in his Treatise, $309 \mathrm{n}$.

Burgesses, admitted to Parliament, 329, 331 .

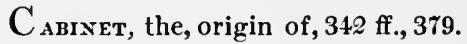

Carolingian institutions, $7 \mathrm{ff}$., $20 \mathrm{f}$.; connection with Anglo-Norman, 29 f., 60,81 n., 86 n., 96 f.

Castle guard, $238 \mathrm{f}$.

Chancery system, the, origination of, in curia regis, $3 \pi 8 \mathrm{f}$.

Charter, Henry I.'s coronation, 27 f., 36 f., 171, 217 ; relation to Magna Carta, 176 f., 247.

Charter, the "unknown," 172 n., $221 \mathrm{n}$.

Charter, the Great. See Magna Carta.

Church, the, grant to, in c. 1 of Magna Carta, 211, 258.

Circuits of counties, first formed in Domesday survey, 85 . 


\section{INDEX}

Clarendon, Assize of, 38, $112 \mathrm{ff}$., 194, $228 \mathrm{f}$.

Clarendon, Constitutions of, $124 \mathrm{ff}$.

Common Pleas. See Court of Common Pleas.

Commonalty, the, $301 \mathrm{n}$.

Commons, House of, 162; as not continuing the curia regis, $315 \mathrm{n}$., 377 ; origin of, $329 \mathrm{f}$.

Commune, the, London and, 385 ff.; meaning of the term, $385 \mathrm{f}$.

Commune concilium regni, and the curia regis, $193,220 \mathrm{n}$.; in clause 12 of Magna Carta, $222 \mathrm{f}$.

Compurgation procedure, the, $117 \mathrm{ff}$., 263; the jury substituted for, in criminal trials, $119 \mathrm{f}$., 268.

Conquest, the Norman, effect of, 4, $18 \mathrm{ff} ., 30$.

Constitution, English, importance of, 1, 43; idea of Saxon, nonfeudal origin of, $3 \mathrm{n}$; Norman influence upon, $16,18 \mathrm{f}$; origin of, $149 \mathrm{ff} ., 275$; the limited monarchy and, 2 ; feudalism and, $3 \mathrm{n}$., 67 n., 147 f., $157 \mathrm{n}$.

Contract, in feudalism, $150 \mathrm{f}$., 169 ff., 203 ff., 232.

Coram rege, 139, 141, 271, 322.

Council, the, 137, 140, 142; summons to the great, 226 ; in Magna Carta, 226 ff.; a parliamentary session of, 142; in the reign of Henry III., 197, 202; continuing the curia regis, 203.

See Curia regis.

Count, the, Frankish, 9 f., 20, 72; of the Normans, 11, $20 \mathrm{f}$.

Court baron, the, age of origin of, 93.

Court of Common Pleas, 131 n.,
271 ; origin of, $136 \mathrm{ff}$., 373 n.; in Magna Carta, 235.

Court of King's Bench, 138 ff., 268.

Courts, American, power to declare laws unconstitutional, 42.

Courts, county, Saxon, 6.

Courts, local, 380 ff.; Frankish, 9, 10; Anglo-Norman, 92, 116 ff., 192.

See County; Hundred; Shire court.

Courts, private, $90 \mathrm{ff}$., $97 \mathrm{ff}$., $264 \mathrm{f}$., 382 ; in early feudalism, $47 \mathrm{f}$.; in last part of thirteenth century, 53, 292; the lord's cases in, 79, 94 ff., $100 \mathrm{f}$. ; in Anglo-Norman feudalism, $192 \mathrm{f}$; ; in c. 39 of Magna Carta, 265.

See Jurisdiction, private.

Criminal procedure, in the Assize of Clarendon, $115 \mathrm{ff} ., 268$; in the local courts, $116 \mathrm{ff}$.

Curia regis, Frankish, i0; AngloNorman, 56 ff., 193; institutional basis of, 57 f., 193; composition of, 61 ff., 105, $227 \mathrm{n}$.; procedure in, 64 ; functions of, $68 \mathrm{ff}$., $374 \mathrm{f}$.; itinerant justice court as, $130 \mathrm{f}$.; descent of its functions, 142, 164, 373 ff.; legislation by, 16+ f., $194 \mathrm{ff}$; in c. 14 of Mlagna Carta, $226 \mathrm{ff}$; how transformed into Parliament, 315, 317; differentiation of, $140 \mathrm{ff}$., $373 \mathrm{ff}$.

Curia regis, the small, $62,195 \mathrm{ff}$., $375 \mathrm{ff}$; composition of and relation to great curia, $66 \mathrm{ff}$., 164, 375 ; and court of Common Pleas, $137 \mathrm{ff}$; legislation by, $194 \mathrm{ff}$.

See Court of Common Pleas; Court of King's Bench; Exchequer; Council. 


\section{INDEX}

Declaration of Independence, the American, relation of, to Magna Carta, 253.

Default of justice, 96, 99.

Deposition of the king, $181 \mathrm{n}$., $299 \mathrm{f}$. ; in Magna Carta, 179; of John, $184 \mathrm{n}$.

Dienstrecht, the, 94 .

Differentiation of feudal into modern institutions, 63, $140 \mathrm{ff}$., $201 \mathrm{f}$., 373-379.

Diffidatio, the, $181 \mathrm{ff} ., 306,312$.

Distraint, of the lord of a court, 96 ; by the lord, $101 \mathrm{f}$.

Domesday Book, feudalism in, $33 \mathrm{n}$.; royal ownership of land in, 38.

Domesday Survey, $84 \mathrm{f}$.

E Art, the, Saxon, 18; Anglo-Norman, 19, 24.

Edward I., reign of, constitutionally, 164, $307 \mathrm{f}$; ; and the formation of Parliament, 337.

Edward II., constitutional character of his reign, 159.

Edward III., Parliamentary control of officers of, 159 n., 161 n., 165.

Election of the king, the right of, $299 \mathrm{n}$.

Errors, a court of, origin of, 143.

Exchequer, the, a small curia regis, 66 n., 138, 141, 197, 271, 376, 378.

Falaise, treaty of, 187.

Fealty, Homage and, $203 \mathrm{f}$.

Ferm, the county, $236 \mathrm{f}$.

Feudalism, Saxon, 17 f., 44 ff.; development of, under William II., 35 f.; under Henry I., 27 f.; Henry II. and, 36 n., 131 f.,
144 ff.; Anglo-Norman, 30 ff., 147 ff., 186 ff., 230 ; in thirteenth century, 53 f., 91, 153, 292, 317; Norman pre-Conquest, 31 f.; highest period in England, $37 \mathrm{f}$; Frankish, 47; distinction between economic and political, $50 \mathrm{ff}$., $219 \mathrm{f}$.; feudal origin of the constitution, 3 n.; and a centralized monarchy, 30 n., 144 ff.; as machinery of government, 60,144 f.; logical character of English, 149, $186 \mathrm{ff}$.

See Law, feudal; Contract; Jurisdiction, private.

Financial Revolution, of XII. and XIII. centuries, 236, 295.

Fine, the, finalis concordia, $130 \mathrm{n}$. France, institutions of, similar to England's, 150, 239 n., 270.

Frankish institutions, $8 \mathrm{ff}$.

See Carolingian institutions.

Freeman, the common, his judicial position, $90 \mathrm{ff}$.

See Liberi homines.

Fustel de Coulanges, Views of, on the growth of the manor, $48 \mathrm{ff}$.

Fyrd, the. See Levy, general military.

Grorge III., and Blackstone's Commentaries, $309 \mathrm{n}$.

Gesta, the author of the, his technical knowledge, 136.

Glanvill, Tractatus, comment on XII. $25,96 \mathrm{ff}$; the writ in, $112 \mathrm{n}$. Glanvill, Ralph de, decision by, $174 \mathrm{n}$.

Goodwin vs. Fortescue, $166 \mathrm{n}$.

Grosseteste, Robert, bishop of Lincoln, 286 n., 288 n., 311 f. 


\section{INDEX}

HeNRy 1., character and power as king, $26 \mathrm{ff}$., $38,106 \mathrm{n}$.; coronation charter of, $27 \mathrm{f}$., $36 \mathrm{f}$., $1 \tilde{1}, 1 \tilde{6} 6 \mathrm{f}$; use of prerogative processes under 88 f., 111 n.; his writ concerning local courts, $122,380 \mathrm{ff}$.

Henry II., character and age of, 106 ff.; institutional changes under, $109 \mathrm{ff}$;; effect of the changes under, 128 f., 134 f., 144 ff., 269.

Henry III., Magna Carta in his reign, 275-310; character of, 280 ff., 284 f., 309 ; financial diffculties of, $280,281 \mathrm{n}$.; difference of his reign from John's, $289 \mathrm{ff}$; precedents established under, 184 n.; council under, 197, 202; legislation under, $199 \mathrm{ff}$.

Homage, as creating the feudal contract, $203 \mathrm{ff}$.

Household, the king's, as sharing in government, 71 .

Hundred court, 6, 117; Henry I.'s writ concerning, $380 \mathrm{ff}$.; in writ of William I. on ecclesiastical cases, $383 \mathrm{n}$.

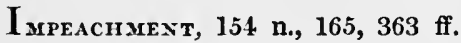
Incrementum, the, from counties and manors, $237 \mathrm{n}$.

Inheritance, in feudal law, 215.

Inquest of Sheriffs, the, 73.

Investiture, lay, $23 \mathrm{n}$.

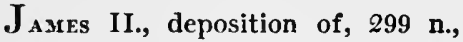
313 ; character of his reign, 334.

Jerusalem, Kingdom of, feudalism of, 104 f., 181 n., 194.

$\mathrm{Jew}$, the, in Magna Carta, 260.

John, King, his power, 135, $151 \mathrm{f}$; and feudal rights, 172 f., 207-274; finances of, 237, 295; assemblies in 1213 under, $339 \mathrm{ff}$; and a commune of London, $356 \mathrm{ff}$.; tendency in his reign, 147,151 , 218; homage of, to the pope, $152 \mathrm{n}$.; alone responsible, 291.

Judicial function of curia regis, 69 . Judicial system. See Courts.

Judicium parium, 242 ff., $263 \mathrm{ff}$.

Jurisdiction, private, 90 ff., 192 f.; three kinds, 78 f.; $93 \mathrm{f}$.; attacked by the Assizes, 97 ff., 120 ff., 128 f., 296 f.; feudalism and, $47 \mathrm{f}$.

See Courts, private.

Jury, the, in the Domesday survey, $85 \mathrm{f}$; in the Carolingian age, $86 \mathbf{n}$; in the trial of cases, $86 \mathrm{f}$., $119 \mathrm{f}$., $268 \mathrm{f}$.; in the detection of crime, $115 \mathrm{ff}$; in the assizes, 124 ff.; in Magna Carta, 234 ; and the origin of Parliament, 322.

Justice, the royal, as the baron's peer, 63, $130 \mathrm{n}$., $269 \mathrm{ff}$. ; in the first century, 83 ff., 114; under Henry II., 113 f., 137 ff.; in Magna Carta, 234.

Justices, the itinerant, in the Assize of Clarendon, $113 \mathrm{f}$; as holding a curia regis, $130 \mathrm{f}$.; functions of, $131 \mathrm{ff}$., $377 \mathrm{f}$; ; and court of Common Pleas, $137 \mathrm{ff}$; under Henry I., 114, 383 ff.; in the XIII. century, $134 \mathrm{n}$.

King, the, as suzerain, 23 n., 35 , 38,58 ; in the curia regis, 64 ; as source of justice, 98 ; and the protection of possession, 98, 103; deposition of, $299 \mathrm{f}$; as subject 


\section{INDEX}

to the law, $157 \mathrm{ff} ., 162 \mathrm{f} ., 169 \mathrm{n}$., 250, 294, 310, 354 ff.

See Monarchy; Prerogative.

King's Bench, court of. See Court of King's Bench.

Knight's fee, the, 52.

Lascastrias period, constitutional character of, 157, 166.

Lanfranc, archbishop of Canterbury, letter to William I., 189.

Langton, Stephen, archbishop of Canterbury, 176, 280, 288.

Law, feudal, 36 n., 147 n., 210 n.; the suzerain bound by, $168 \mathrm{f}$., $205 \mathrm{ff}$.

Law, public, in feudalism, 170, 206. See Contract.

Legislation, development of Parliament's control of, $163 \mathrm{ff}$.; feudal, 194 ff.; see Assizes; right of House of Commons in, $315 \mathrm{n}$.

Levy, the general military, AngloNorman, 74, $190 \mathrm{f}$.

Lerves, Song of, the, argument for the barons in, $311 \mathrm{ff}$.

Liberi homines, in Magna Carta, $236,264 \mathrm{f}$.

See Freemen.

Liberty, the, 55; attacked by the Assize of Clarendon, $120 \mathrm{ff}$.; the itinerant justice in, $128 \mathrm{n}$., $382 \mathrm{f}$.

London, charter of William I. for, 14. $\mathrm{f}$; in c. 12 of Magna Carta, 225 ; and the commune, 385.

Lord, the feudal, the trial of his own cases in his court, 79, $94 \mathrm{ff}$., $100 \mathrm{f}$., cf. 64 ; bound by the feudal law, $168 \mathrm{f}$.

See Rechtsgebot.
Lords, House of, as continuing the curia regis, 203, 315 n., 377. Lords Ordainers, the, 159 n., 308.

Louis IX., of France, decision of, on the Provisions of Oxford, 245 n., 260, 308 n.

Magna Carta, analysis of and comment on, 207-274; confirmations of, 160 n., 279 f., $282,286 \mathrm{ff}$., 289 n., 307 f.; relation to origin of the constitution, 167, $249 \mathrm{fr}$.; not a contract, 169 n.; nor a treaty, 212 n.; legally just, 174, 248; clause 34, 97, 233, 239 f.; clause 61,176 ff., 247 f., 275 ff., $297 \mathrm{ff} ., 305 \mathrm{f}$; f feudal in character, $158 \mathrm{ff} ., 210,248$; clause 12, 217 ff., 223,259 f., 276 f., 307 f., 358 f.; clause 39, 242 ff., 259 , $262 \mathrm{ff}$.; changes made in the reissues of, $256 \mathrm{ff}$; clause 14, $226 \mathrm{ff} ., 276 \mathrm{f}$.; in the reign of Henry III., 275-310; reissues of, $256 \mathrm{ff} ., 275,282 \mathrm{f}$; ; as reactionary, 242 f., 275, 283; and charter of Henry I., 37 n., 176 f., 247.

Manor, the Saxon, 46; early history of the, $48 \mathrm{ff}$; the domain, $52 \mathrm{f}$.; position of the freeman in, 91 .

Manorial jurisdiction, 78, 92.

Marriage, the feudal right of, 217, 257.

Marshal, Richard, insurrection of, 189, 190, 272, 287 f., 289 n., 303 n.

Marshal, William, spirit of his government, 279.

Merton, statute of, c. 8, 199.

Monarchy, Saxon, 4 f., 17, 22; Frankish, 8 f., 20, 29; AngloNorman, 17, 20 ff., 58 ff., 98, 134 f., 144 ff., 171; Capetian, 21 ; 


\section{INDEX}

the English limited, $2,41 \mathrm{ff} ., 108$, 152, $156 \mathrm{ff} ., 178,185,250 \mathrm{f}$.

Montfort, Simon de, earl of Leicester, reluctant to accept Provisions of Oxford, 302 n., 303 n.; his character, $303 \mathrm{f}$.; source of his ideas, $311 \mathrm{f}$; summons of Knights to Parliament, 324, $328 \mathrm{f}$; his Parliament of 1265, $328 \mathrm{ff}$.

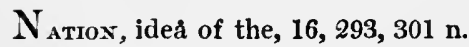

Nisi prius, $138 \mathrm{f}$.

Norman institutions, $7 \mathrm{ff} ., 11 \mathrm{f}$, 21 n., 30; union with Saxon, 13.

Normandy, size and importance, 11, $21 \mathrm{f}$.

Northampton, the Assize of, $126 \mathrm{f}$.

Oیтн. See Compurgation.

Saxon, of man to lord, $44 \mathrm{ff}$; the coronation, not the legal basis of Magna Carta, $182 \mathrm{f}$.

Odo, bishop of Bayeux, 25, 69.

Old Testament, the, source of ideas of the monarchy, 58.

Opposition, formation of a party of, $307 \mathrm{n}$.

Ordeal, the, in criminal trials, $119 \mathrm{f}$.

Ordinance, the, as distinguished from statutes, $201,315 \mathrm{n}$.

Oswald, Bishop, letter of, $44 \mathrm{f}$.

Panimanest, relation to the growth of the limited monarcliy, $15 \mathrm{sff}$., 180, $307 \mathrm{f}$.; control of ministers by, 159 n., 160 n.; growth of its power, $160 \mathrm{n}$., $162 \mathrm{ff}$.; origin of, $314 \mathrm{ff}$., $339 \mathrm{ff}$.; of $1254,317 \mathrm{ff}$.; of $1261,324 \mathrm{f}$.; of $1264,326 \mathrm{ff}$.; of 1265, $328 \mathrm{ff}$.; of $1295,336 \mathrm{n}$.; peculiarities of the English, $330 \mathrm{n}$; in the period from 1265 to $1295,335 \mathrm{ff}$; in clause 14 of Magna Carta, 226.

Patrocinium, the Frankish, 45.

Peer, the king's justice the baron's, 63,130 n., $269 \mathrm{ff}$; in local and private courts, $92 \mathrm{f}$.

Peers, 90 ; trial by, 92, 262 ff., $289 \mathrm{n}$.

See Judicium parium; Justice, the royal; Magna Carta, c. 39.

Petition of the Barons, the (1258), $97,290 \mathrm{n}$.

Petition of Right, the, relation of, to Magna Carta, $252 \mathrm{f}$.

Prerogative, royal, 273; in first Anglo-Norman century, $55 \mathrm{f}$., $58 \mathrm{ff}$., $76 \mathrm{ff}$.; in XII. century, 29; beginning of processes of, in Normandy, 89, 106 n.; applications of, under Henry II., $109 \mathrm{ff}$.

Prerogative judgments, 272 f.

Primer seisin, not in Magna Carta, $215 \mathrm{n}$.

- Procedure, 14 n., 64 ff., 82, 94, 140 f., 268.

Proficuum, the, from counties, $237 \mathrm{n}$.

Protestation, the, of $1621,212 \mathrm{n}$.

Provisions of Oxford, the, $157 \mathrm{n}$., 160, $298 \mathrm{ff}$., 301 n., 303 n., $304 \mathrm{ff}$. Provisions of Westminster, the, 292 n., 304.

Purveyance, the right of, in Magna Carta, 238,

Rechtsgebot, the, 64 n., 131 n., 201.

Record by four Knights, the, as furnishing the suggestion of parliamentary representation, $320 \mathrm{ff}$. lielief, the feudal, $51,213 \mathrm{ff}$. 


\section{INDEX}

Representation, the idea of parliamentary, 319 f., $335 \mathrm{n}$.

Revenue, from the counties, $236 \mathrm{f}$.; feudal, $219 \mathrm{f}$., $255 \mathrm{ff}$.

Richard I., 135, 387; tendency in his reign, 14\%, 151, $218 \mathrm{n}$; ; and a commune of London, 387.

Richard II., constitutional character of his reign, $159,161 \mathrm{n}$., 165,332 f.; deposition of, $299 \mathrm{n}$., $309 \mathrm{n}$.

Richard, earl of Cornwall, brother of Henry III., 284 f., 302 f.

Richard, duke of York, claim to the throne, 167.

Roturier, the, 93.

Sr. Alraxs, the assemblies at, in 1213, $339 \mathrm{ff}$.

Saladin tithe, the, 218 n., $228 \mathrm{n}$.

Salisbury Oath, the, $186 \mathrm{f}$.

Saxon institutions, $4 \mathrm{ff}$.; union with Norman, 13 ; local, after the Conquest, 19.

Scutage, 39, 92, 128 n., 218 n.; in Magna Carta, 221 ff., 238 f.

Serf, the, position in manorial courts, 92.

Serjeanty tenure, the, $63 \mathrm{n}$., $241 \mathrm{f}$. Sheriff, the, Saxon, 5; Anglo-Norman, 19, 72 ff., 83; as king's commissioner or justice, $80 \mathrm{n}$., 234, 384; in the Assize of Clarendon, 113 f., 120; inquest of sheriffs in 1258, 323; supervised by the itinerant justices, $132 \mathrm{f}$.

Shire court, Saxon, 6; the bishop in, 383. See Courts, county.

Sovereignty, of the people, in Anglo-Saxon constitutions, $11 \mathrm{f}$.; transfer of, to Parliament, $296 \mathrm{n}$.

Star Chamber, court of, origin in the council, $378 \mathrm{f}$.
Statutes. See Ordinance.

Stephen, King, character of his reign, 28, 39.

Stuart age, the, constitutional character of, $333 \mathrm{f}$., $353 \mathrm{ff}$.

Suit of court, in baronial courts, $292 \mathrm{n}$.

Suzerain, the feudal. See Lord, feudal; King, the, as suzerain.

' 'allage of domains, 255, $389 \mathrm{ff}$.; of London, $389 \mathrm{ff}$.

Taxation, development of Parliament's control of, 163 f., 308, $315 \mathrm{n}$.; feudalization of. $191 \mathrm{f}$;; in Magna Carta, 217 ff.; development of, in Anglo-Norman England, 218 n.; under Henry III., 290.

Treason, guilt of, not incurred in regular feudal warfare, $181 \mathrm{f}$.; trials for, 69.

Tudor age, the, constitutional character of, 333 .

U wited States, Anglo-Saxon constitution in, $41 \mathrm{f}$.

Urteilfindung, the, $64 \mathrm{n}$.

Utrum, the assize, $125 \mathrm{f}$.

$V_{\text {Assal, }}$ the, position in feudalism, $62 \mathrm{f} ., 170,18 \%$.

Village community, existing beside the manor, $49 \mathrm{f}$.

Viscount, the, Norman, $11 \mathrm{f} ., 72 \mathrm{f}$.

$W_{\text {AR, private, in Anglo-Norman }}$ feudalism, $187 \mathrm{ff}$.

Wardship, feudal, $216,240 \mathrm{ff}$.

William I., attitude as conqueror, $14 \mathrm{ff}$; his kingdom and government, 17, 21 f., 24 f.; and feudalism, $34,15 s$; use of preroga- 


\section{INDEX}

tive processes under, 84 f., 88; separation of ecclesiastical and lay jurisdiction, 68, $383 \mathrm{f}$.

William II., and Anselm, 23 n., $70,171 \mathrm{n} . ;$ power as king, $25 \mathrm{f}$; personal character, 25 ; and feudalism, 35 f., 17 I, 176, 214 n.

William, son of Henry I., his writ to the bishop of Bath, $80 \mathrm{n}$.; homage of, to Louis VI., 204.

Witenagemot, the, $6,17,57,65$.

Writ, the, as means of prerogative action, 76. ff., 111; the AngloSaxon, 77, 81 n.; as permission to use the royal procedure, $8 \mathrm{i} \mathrm{f}$., 129.

Writ, the, of cosinage, $233 \mathrm{n}$.

Writ, the, of right, $100 \mathrm{ff}$; in the first century, $78 \mathrm{ff}$; under Henry II., 129.

Writ of 1254, $318 \mathrm{ff}$.

Writ Præcipe, 103 ff., 233 n.; in the first century, $80 \mathrm{ff}$.; its Carolingian origin, 81 n., 96 f.; under Henry II., 129; in Magna Carta, 239 f.; under Henry III., 292; and feudal law, 173.

Writs of execution, $272 \mathrm{f}$. 

PRINTED IN THE CNITED STATES OF AMERICA 






\section{Date Due}

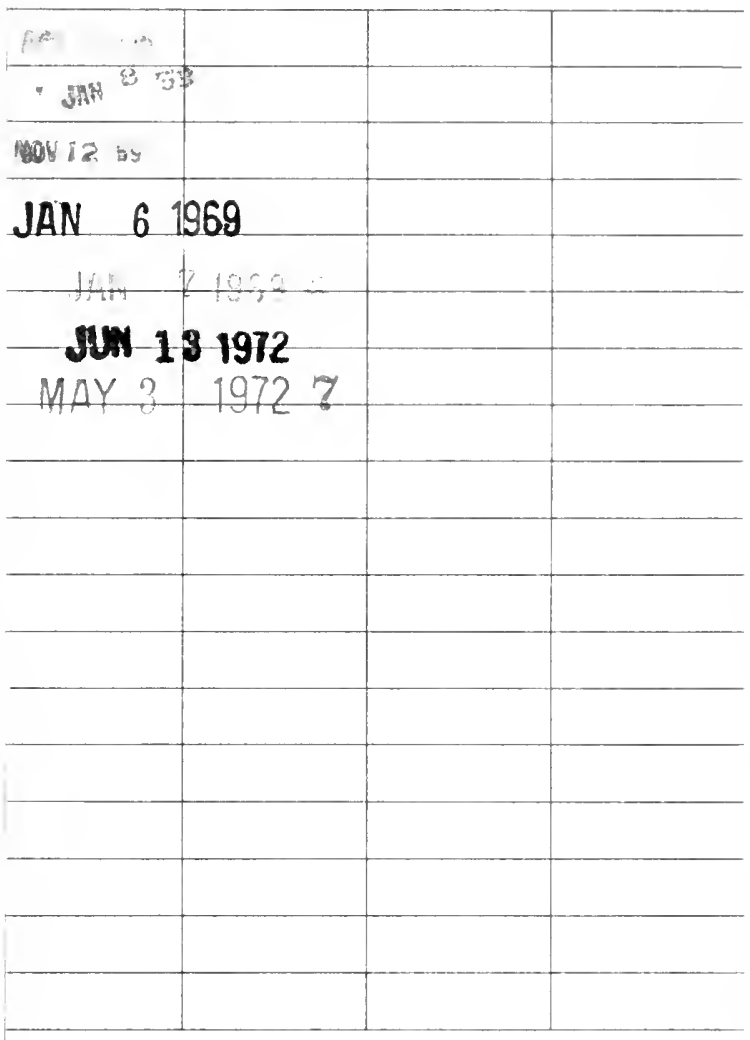

Library Bureau Cat. No, 1137

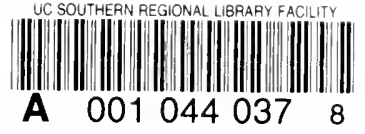


